PAULO JOSÉ LEONESI MALUF

\title{
CONSELHO NACIONAL DE JUSTIÇA: ANÁLISE DE SUA COMPETÊNCIA DISCIPLINAR
}

Dissertação de Mestrado

Orientador: Professor Titular Marcelo da Costa Pinto Neves

UNIVERSIDADE DE SÃO PAULO

FACULDADE DE DIREITO

SÃO PAULO

2013 
PAULO JOSÉ LEONESI MALUF

CONSELHO NACIONAL DE JUSTIÇA: ANÁLISE DE SUA COMPETÊNCIA DISCIPLINAR

Dissertação de Mestrado apresentada ao Programa de Pós-Graduação da Faculdade de Direito da Universidade de São Paulo, como requisito parcial à obtenção do grau de Mestre em Direito do Estado, realizada sob a orientação do Professor Titular Marcelo da Costa Pinto Neves

UNIVERSIDADE DE SÃO PAULO

FACULDADE DE DIREITO

SÃO PAULO

2013 


\section{FOLHA DE APROVAÇÃO}

Candidato: Paulo José Leonesi Maluf

CONSELHO NACIONAL DE JUSTIÇA:

ANÁLISE DE SUA COMPETÊNCIA DISCIPLINAR

Departamento de Direito do Estado

Banca Examinadora:

Prof. Dr.

Instituição:

Julgamento:

Assinatura:

Prof. Dr.

Instituição:

Julgamento:

Assinatura:

Prof. Dr.

Instituição:

Julgamento:

Assinatura:

São Paulo, de de 2013. 
AGRADECIMENTOS E DEDICATÓRIA

Ao Professor Marcelo Neves, pelo exemplo de acadêmico, professor e pessoa séria e dedicada, com quem muito aprendi, e que muito me honra pela orientação.

Ao Professor José Levi Mello do Amaral Junior, que desde o início da fase de elaboração de um projeto de pesquisa para o ingresso no Mestrado, sempre me recebe muito gentilmente, pela oportunidade de acompanhá-lo nas monitorias e pelas sugestões dadas no Exame de Qualificação.

Ao Professor Marcos Paulo Veríssimo, pelos valiosos comentários sobre a Dissertação durante o Exame de Qualificação; nunca me esqueço de suas palavras - "você vai ter que estudar muito!".

Aos meus amigos da Procuradoria-Regional da Fazenda Nacional, Amanda Becke, Ana Carolina Vasques, Ana Carolina Camurça, Antônio Carlos Meirelles, Carla Pirá, Carlos Alexandre Torres, Catheriny Baccaro, Clarissa Navarro, Dacier Almeida, Diogo Signoretti, Eduardo Marrochio, Eduardo Rodrigues, Edson Melo, Estéfano Nonato, Fábio Vargas, Fernanda Bonotti, Ilan Presser, Ivo Timbó, Luciane Hamaguchi, Mariana Ratkza, Marina Miura Pricoli, Martina Rigaud, Raquel Carvalho, Renata Pacheco, Roberta Bhering, Tatyana Simões, Túlio Tonelli, Vanessa Pinotti, Victor Jen Ou e Vivian Leinz, pela alegre convivência quase diária e pelo incentivo. Registro um agradecimento especial ao Ivo e à Vanessa, pelo fundamental apoio nos momentos finais de redação da dissertação. Também merecem especial agradecimento as acadêmicas de Direito e estagiárias da Procuradoria Alessandra Simplício e Thainara Pratt, pela dedicação, pela competência e por todo o auxílio que sempre me deram. 
Aos meus amigos Guilherme Wood, Odair Rehder e Rodrigo Melo, pela saudosa convivência durante a Graduação na Sanfran; à Nathalie Albieri, pela amizade e pela ajuda com a tradução para o inglês; aos amigos que fiz durante o Mestrado, Andrea Gonçalves, Juliana Diniz, Marina Lima, Pedro Henrique Ribeiro e Vinícius Poli, pelas pessoas incríveis que são e pela convivência e aprendizado conjunto nesta importante etapa de nossas vidas.

Aos meus grandes amigos Elisabeth Freitas, pela amizade, e pelo exemplo de pessoa que sempre está alegre e com um sorriso no rosto, e Leandro Vilarinho, pelo companheirismo, pela amizade fraternal, pelo apoio sempre presente e, nesta reta final de trabalho, pelas palavras (de) “força!".

À Mariana, por deixar as coisas mais "divertidas e alegres", por sempre rezar por mim, pelo apoio e pelo carinho.

À minha irmã Elisa, aos meus pais Angela e Paulo, e a Deus, por serem tudo para mim e por estarem sempre comigo.

A todos eles dedico este trabalho. 
"Todo homem que tem poder é tentado a abusar dele. Vai até onde encontra limites. (...) Para que não se possa abusar do poder, é preciso que, pela disposição das coisas, o poder freie o poder."

Charles Louis de Secondat, baron de la Brède et de MONTESQUIEU 


\section{RESUMO}

O presente estudo tem por objeto central a análise da competência disciplinar do Conselho Nacional de Justiça. Trata-se de competência concorrente ou de competência subsidiária, relativamente à atribuições das Corregedorias dos Tribunais locais? Mais do que apresentar a resposta em si - competência de natureza concorrente -, o trabalho busca apresentar as justificativas para esta resposta. Esta tarefa é realizada a partir da contextualização da criação do Conselho, da apresentação de sua estrutura e de seu funcionamento, bem como do entendimento jurisprudencial do Supremo Tribunal Federal acerca da constitucionalidade de sua instituição pela Emenda Constitucional n. 45, de 2004. A competência disciplinar do Conselho Nacional de Justiça busca alcançar um equilíbrio entre os importantes valores da independência e da responsabilização judicial, apresentando estreita relação com a noção de accountability e com o princípio da publicidade. Sua dimensão processual é estudada por meio da abordagem da Resolução $n$. 135, de 2011, que disciplina o procedimento administrativo disciplinar, da Medida Cautelar na Ação Direta de Inconstitucionalidade n. 4.638, e de decisões do próprio Conselho e do Supremo Tribunal Federal.

PALAVRAS-CHAVE: Conselho Nacional de Justiça - Competência Disciplinar - Poder Judiciário/Magistratura - Resolução n. 135/2011 - Independência, Responsabilização, Accountability 


\section{RIASSUNTO}

Il presente studio ha come scopo centrale l'analisi della competenza disciplinare del Conselho Nacional de Justiça [Consiglio Nazionale di Giustizia - organo di controllo amministrativo e finanziario del sistema giudiziario brasiliano e di supervisione sull'operato dei magistrati]. Le attribuzioni delle Corregedorias [Ispettorati giudiziari] delle Corti locali raffigurano un esempio di competenza concorrente ovvero residuale rispetto alle attribuzioni del Conselho Nacional de Justiça? Oltre a fornire la risposta al quesito formulato, competenza di tipo concorrente, il lavoro cerca di esporre le giustificazioni a tale risposta. L'obiettivo è conseguito tracciando le ragioni che hanno portato alla costituzione del proprio Conselho Nacional de Justiça, illustrandone la struttura e il suo funzionamento, nonché la comprensione giurisprudenziale del Supremo Tribunal Federal [Corte Suprema Federale] riguardo alla costituzionalità della sua istituzione attraverso l'emendamento costituzionale n. 45 del 2004. La competenza disciplinare del Conselho Nacional de Justiça mira a raggiungere un equilibrio tra i valori fondamentali di indipendenza e di responsabilità dei magistrati, rivelando un nesso inscindibile con la nozione di accountability e il principio di pubblicità. L'aspetto procedurale è esaminato attraverso l'analisi della Risoluzione n. 135 del 2011, che regola la procedura disciplinare amministrativa, lo studio delle misure cautelari nella Ação Direta de Inconstitucionalidade [Azione Diretta di Incostituzionalità] n. 4.638 e le decisioni dello stesso Conselho Nacional de Justiça e del Supremo Tribunal Federal.

PAROLE-CHIAVE: Consiglio Nazionale di Giustizia - Competenza Disciplinare Giudiziario/Magistratura - Risoluzione n. 135/2011 - L'indipendenza, la responsabilità, accountability 


\begin{abstract}
The subject matter of this study is an analysis of the disciplinary power of Conselho Nacional de Justiça [Brazil's National Council of Justice - Body in charge of control the administrative and financial operation of the Judicial Branch and the proper discharge of official duties by judges]. Is it a concurrent or subsidiary competence, in regard to the roles of corregidors in local Courts? More than providing the answer itself - concurrent competence -, this paper aims to give reasons for that answer. This task is undertaken by contextualizing how the Council was set up; by presenting its structure and its operation; and by presenting Supremo Tribunal Federal [Brazil's Supreme Federal Court] legal precedents regarding the constitutionality of its creation by Constitutional Amendment number 45 of 2004. The National Council of Justice's disciplinary competence aims to achieve a balance between the important values of independence and legal responsibility, and it is closely related to the concept of accountability and with the principle of publicity. Its procedural dimension is studied according to the approach of: Resolution number 135 of 2011, which regulars disciplinary administrative proceedings; the Ação Direta de Inconstitucionalidade [action of unconstitutionality] number 4.638; and decisions handed down by the Conselho Nacional de Justiça itself and the Supremo Tribunal Federal.
\end{abstract}

KEYS WORDS: National Council of Justice - Disciplinary Competence/Powers Judiciary/Magistracy - Resolution n. 135/2011 - Independence, Responsibility, Accountability 


\section{SUMÁRIO}

INTRODUÇÃO..............................................................................................................

\section{CAPÍTULO I - CONTEXTUALIZAÇÃO DA CRIAÇÃO DO CONSELHO} NACIONAL DE JUSTIÇA ...................................................................................................10

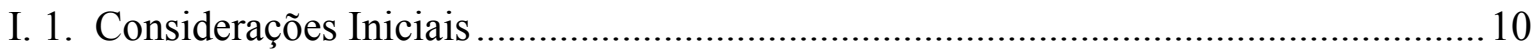

I. 2. O momento pré-Reforma do Judiciário: breve diagnóstico da situação do Poder

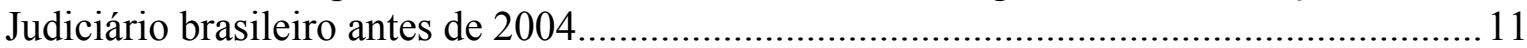

I. 3. A necessidade de reforma do Poder Judiciário.............................................................. 18

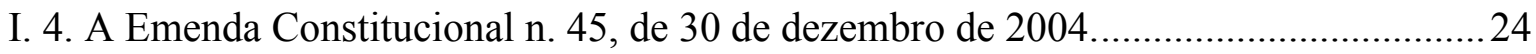

I. 5. Conselhos de Justiça no Direito Comparado................................................................ 31

I. 5.1. Panorama geral dos Conselhos de Justiça em outros ordenamentos jurídicos. 31

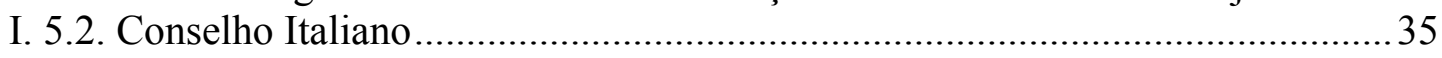

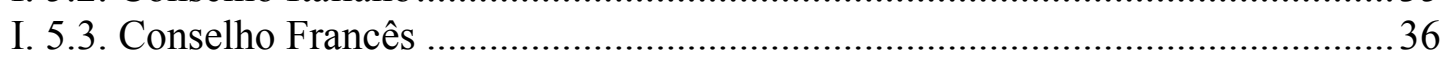

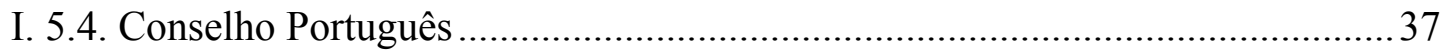

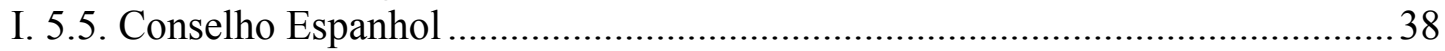

I. 5.6. Outros Conselhos de Justiça: Bélgica, Turquia, Andorra, Irlanda, Suécia e

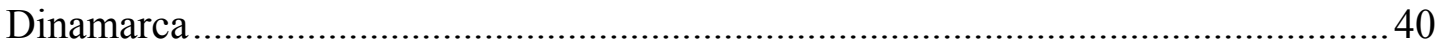

I. 5. 7. Algumas importantes observações ……................................................... 42

\section{CAPÍTULO II - ESTRUTURA E FUNCIONAMENTO DO CONSELHO}

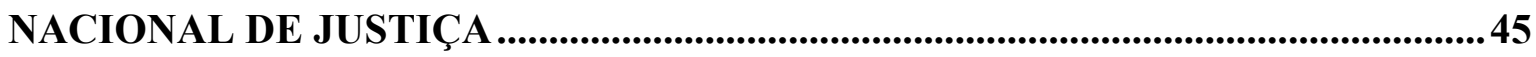

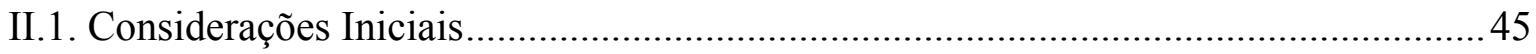

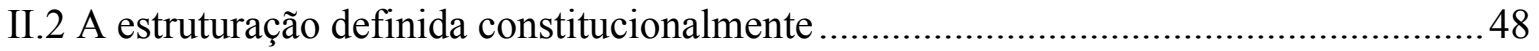

II.3 A estruturação e o funcionamento definidos regimentalmente...................................51

II.4. Competências, atribuições e aspectos institucionais relevantes...................................56

CAPÍTULO III - ENTENDIMENTO JURISPRUDENCIAL ACERCA DA CONSTITUCIONALIDADE DA CRIAÇÃO DO CONSELHO NACIONAL DE JUSTIÇA: AS PRINCIPAIS DEFINIÇÕES A PARTIR DOS JULGAMENTOS DA

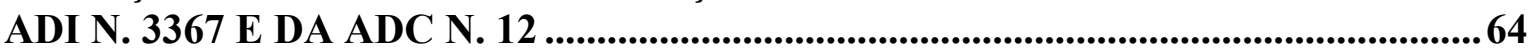

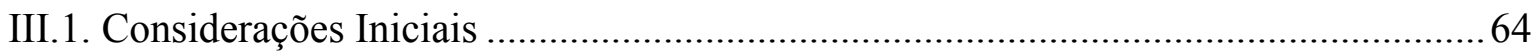

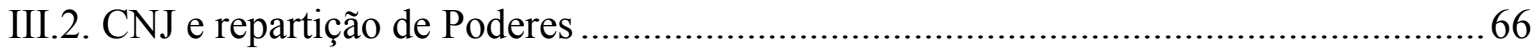

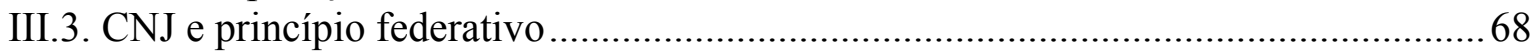

III.4. CNJ e independência e responsabilização da Magistratura ....................................... 71

III.5. Breves notas sobre o Poder Regulamentar do Conselho Nacional de Justiça ............. 74 


\section{CAPÍTULO IV - A COMPETÊNCIA DISCIPLINAR DO CONSELHO NACIONAL DE JUSTIÇA........................................................................................................................ 80}

IV.1. Considerações Iniciais

IV.2 Aspectos gerais relativos à competência: definição de competência e relação com a temática dos controles da Administração Pública e com a doutrina dos poderes administrativos.

IV.3. Competência disciplinar do Conselho Nacional de Justiça entre Independência e

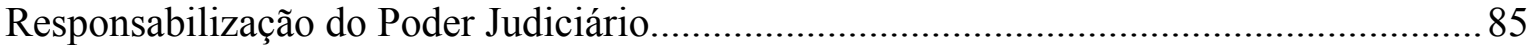

IV.4. Competência disciplinar e accountability ...............................................................96

IV.5. Competência disciplinar e princípio da publicidade................................................ 101

IV.6. Natureza da competência disciplinar do Conselho Nacional de Justiça, relativamente às atribuições das corregedorias dos tribunais em geral: concorrente ou subsidiária? .......103

\section{CAPÍTULO V - DIMENSÃO PROCESSUAL DA COMPETÊNCIA DISCIPLINAR} DO CONSELHO NACIONAL DE JUSTIÇA …………………........................................114

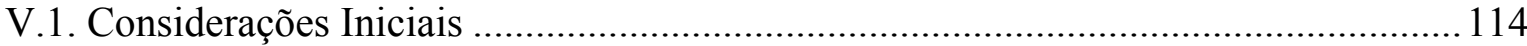

V.2. Dos processos no âmbito do Conselho Nacional de Justiça no exercício de sua

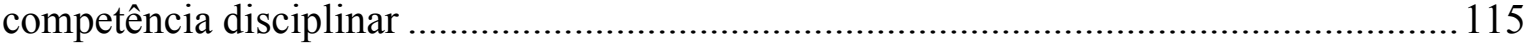

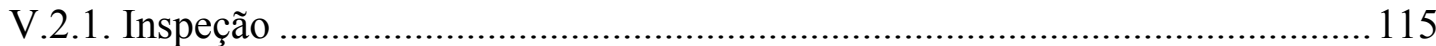

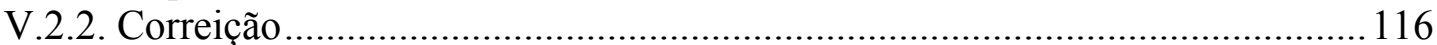

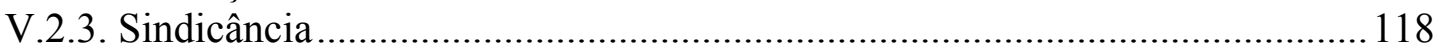

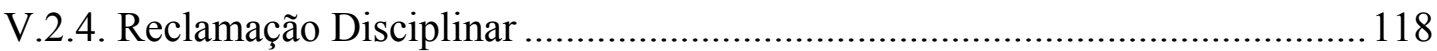

V.2.5. Processo Administrativo Disciplinar ............................................................ 119

V.2.6. Representação por excesso de prazo ……………………………………...... 120

V.2.7. Avocação de processo de natureza disciplinar................................................ 120

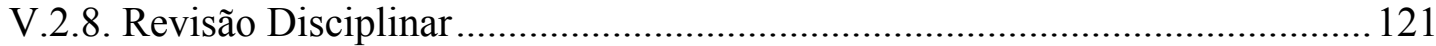

V.2.9. Procedimento de Controle Administrativo ...................................................... 122

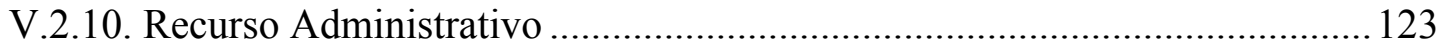

V.3. O procedimento administrativo disciplinar previsto na Resolução n. 135/2011, do Conselho Nacional de Justiça .......................................................................................... 124

V.4. A Ação Direta de Inconstitucionalidade n. 4638-MC - análise da constitucionalidade

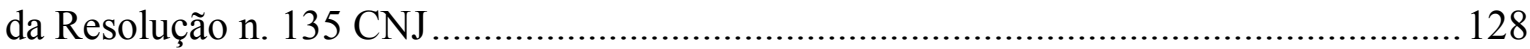
V.5. A competência disciplinar do Conselho Nacional de Justiça à luz de suas próprias decisões

V.6 A competência disciplinar do Conselho Nacional de Justiça à luz de decisões do Supremo Tribunal Federal

V.7. Breves notas sobre a relação entre o Conselho Nacional de Justiça e o Supremo Tribunal Federal.

CONSIDERAÇÕES FINAIS.................................................................................................... 166

REFERÊNCIAS BIBLIOGRÁFICAS.....................................................................170

BIBILIOGRAFIA CONSULTADA............................................................................177

ANEXO I - QUADRO ESQUEMÁTICO - RESUMO DO JULGAMENTO DA ADI

4638-MC 


\section{INTRODUÇÃO}

A Emenda Constitucional n. 45, de 30 de dezembro de 2004, introduziu a chamada "Reforma do Judiciário", e trouxe à discussão diversos temas importantes no âmbito do Direito Constitucional brasileiro.

Uma das principais questões, senão a principal ${ }^{1}$, suscitada pela a Emenda $n$. 45/2004, foi a criação do Conselho Nacional de Justiça, um dos reflexos mais evidentes da formalização do "Pacto de Estado em favor de um Judiciário mais Rápido e Republicano", celebrado, por ocasião da Reforma Constitucional, pelos Chefes dos Três Poderes.

A criação de um órgão com as feições formais (elevada posição hierárquica nos quadros judiciários nacionais) e materiais (competências constitucionais) do Conselho Nacional de Justiça trouxe a lume, em curto lapso temporal, algumas discussões, tanto em âmbito doutrinário, como no plano jurisprudencial, sobre a constitucionalidade ou inconstitucionalidade deste órgão (em especial mediante sua colocação diante dos princípios da separação de poderes e do Estado federal) e sobre os limites de sua atuação e de suas competências (sobretudo por meio da análise de suas competências em face de nosso modelo constitucional de repartição de competências).

Diferentemente da experiência de outros países, a instituição do Conselho Nacional de Justiça, no Brasil, não ocorreu para responder a anseios da Magistratura por maior autonomia e independência, tampouco para impedir a ingerência de outros Poderes no Judiciário ${ }^{2}$.

Sobre o objetivo da instituição do Conselho Nacional de Justiça, José dos Santos Carvalho Filho enuncia que "o escopo fundamental dos novos Conselhos" [de Justiça e do Ministério Público], cuja "instituição foi realmente necessária diante do cenário então existente" foi o de "executar poder correcional e enfrentar o abuso de poder, inafastável quando se trata de órgãos de elevada estatura constitucional". 3

\footnotetext{
${ }^{1}$ Luiz Armando Badin (2008, pp. 27-39) considera que o Conselho Nacional de Justiça é "a pedra angular da reforma constitucional do Poder Judiciário".

${ }^{2}$ Nesse sentido, destacam-se, dentre outros autores, Sampaio, 2007 e Mendes, 2012.

${ }^{3}$ Carvalho Filho, 2010, pp. 16-17.
} 
Segundo o entendimento do Ministro Gilmar Mendes, do Supremo Tribunal Federal, “a instituição do Conselho Nacional de Justiça visou, sobretudo, à adoção de mecanismos de controle eficaz da atividade administrativa dos vários órgãos jurisdicionais". Em outras palavras, para o Ministro Gilmar Mendes, a instituição do Conselho Nacional de Justiça objetivou principalmente a integração e a coordenação dos diversos órgãos jurisdicionais do país, por meio de um organismo central com atribuições de controle e fiscalização de caráter administrativo, financeiro e correcional. Sob esta perspectiva, o Conselho apresenta-se "mais como órgão de coordenação e planejamento das atividades administrativas do Poder Judiciário do que propriamente como órgão disciplinador". 4

Maria Tereza Sadek, por sua vez, considera que os objetivos de criação do Conselho Nacional de Justiça vão além de uma mera racionalização da forma de se administrar a Justiça e do zelo pela independência do Judiciário. Para ela, estão mais relacionados com o "estabelecimento de accountability, fiscalização e controle para modernização do funcionamento interno do Poder, racionalizando o uso dos recursos humanos e financeiros, bem como evitando o nepotismo, a corrupção, a má gestão e desperdícios". 5

Independentemente da ênfase que se queira dar aos escopos principais do Conselho Nacional de Justiça, é inegável o fato de que sua instituição buscou modificar a conjuntura em que se encontrava o Poder Judiciário no momento anterior à Reforma implementada pela Emenda Constitucional n. 45, de 30 de dezembro de 2004.

Com efeito, o Poder Judiciário brasileiro carecia de um órgão central de administração do sistema de Justiça, com atividades de política judiciária - zelando, por exemplo, por sua autonomia e pelo cumprimento do Estatuto da Magistratura -, e de gestão administrativa - definindo e promovendo planejamento estratégico, planos de metas e programas de avaliação institucional do Poder Judiciário.

E, em igual medida, a sociedade brasileira demandava de seu Judiciário maior proximidade com os cidadãos - com a possibilidade de oferecer reclamações, petições eletrônicas e representações contra membros ou órgãos do Judiciário - maior moralidade, eficiência e transparência na prestação dos serviços judiciais - com a efetiva

\footnotetext{
${ }^{4}$ Mendes, 2008, pp. 3-4 e Mendes, 2012, sem paginação.

${ }^{5}$ Sadek, 2001, p. 47.
} 
punição de desvios de conduta, maior celeridade na prestação jurisdicional e maior informação sobre dados do Judiciário em todo o País.

A criação do Conselho Nacional de Justiça, contudo, não ocorreu sem que houvesse muita resistência e crítica, sobretudo de indivíduos e setores do meio jurídico e político que viam no Conselho um órgão de controle externo ao Poder Judiciário. Com isso, o processo de Reforma do Judiciário arrastou-se por mais de uma década.

Muitas discussões se deram antes da criação do Conselho Nacional de Justiça, bem como muitas outras permaneceram após o seu estabelecimento. Com efeito, após a sua instituição, discutiu-se bastante a respeito de sua legitimidade. Nesse sentido, o maior destaque cabe ao julgamento da Ação Direta de Inconstitucionalidade n. 3367, em que o Supremo Tribunal Federal declarou a constitucionalidade da criação do Conselho Nacional de Justiça em face do princípio da repartição de poderes e do princípio federativo. Neste mesmo julgamento, entendeu-se também que sua criação não fere o princípio da independência judicial.

Passadas estas questões iniciais, o foco das discussões em torno do Conselho Nacional de Justiça voltou-se para a análise de suas competências e de suas atribuições e, nesse sentido, sobre estas matérias não se vislumbra entendimento pacífico em nossa doutrina e em nossa jurisprudência.

Dentre as diversas competências conferidas ao Conselho Nacional de Justiça, apresenta especial destaque sua competência disciplinar - objeto central do trabalho que ora se inicia.

Pode-se considerar, em uma análise preliminar, que a competência disciplinar do Conselho Nacional de Justiça é resultado da busca por um delicado equilíbrio entre independência e responsabilidade judicial, e sua associação com os mecanismos de accountability ${ }^{6}$.

No exercício de sua competência disciplinar, o Conselho Nacional de Justiça vale-se, ainda que indiretamente, da edição de resoluções, as quais são decorrências, de forma direta, de uma outra competência sua - a competência regulamentar.

\footnotetext{
${ }^{6} \mathrm{O}$ tema da accountability e sua relação com a competência disciplinar do Conselho Nacional de Justiça será analisado em item específico, no capítulo IV.
} 
Fruto de seu poder normativo é a Resolução n. 135, de 13 de julho de 2011, que estabelece uma uniformização das normas relativas ao procedimento administrativo disciplinar aplicável aos magistrados, dispondo acerca do rito e das penalidades aplicáveis.

Com a edição de tal instrumento normativo, ganhou relevo a discussão acerca da natureza da competência disciplinar do Conselho Nacional de Justiça. E é neste ponto em que surge a questão central do presente trabalho: trata-se, relativamente às atribuições das corregedorias dos tribunais em geral, de competência de natureza concorrente ou de competência de caráter subsidiário?

Para responder a esta questão, de forma fundamentada, e de acordo com as exigências de uma dissertação desenvolvida como requisito parcial para a conclusão do curso de Mestrado, é necessária uma compreensão adequada e relativamente abrangente do Conselho Nacional de Justiça como um todo. Para tanto, desenvolveu-se a dissertação da seguinte forma.

No capítulo primeiro, é apresentada uma contextualização do Conselho Nacional de Justiça. Parte-se de um breve diagnóstico do Poder Judiciário no momento anterior à Reforma do Judiciário, seguido da apresentação da necessidade de alterações na conjuntura encontrada no seio daquele Poder, culminando com a elaboração e promulgação da Emenda Constitucional n. 45. Ainda neste capítulo, também com o objetivo de contextualização do Conselho Nacional de Justiça, promove-se um estudo de alguns Conselhos de Justiça no Direito Comparado.

O capítulo segundo trata da estrutura e funcionamento do Conselho Nacional de Justiça. Nesse sentido, discorre-se sobre a estruturação definida constitucionalmente, bem como sobre alguns pontos considerados de maior relevância acerca de suas competências, atribuições e aspectos institucionais.

No capítulo terceiro, empreende-se uma análise da jurisprudência acerca da constitucionalidade da criação do Conselho Nacional de Justiça, por meio das principais definições a partir dos julgamentos da Ação Direta de Inconstitucionalidade n. 3367 e da Ação Declaratória de Constitucionalidade n. 12. Em tais julgamentos, no exercício do controle de constitucionalidade atribuído ao Supremo Tribunal Federal, analisou-se a adequação do Conselho em face do princípio da repartição de Poderes e do princípio federativo, bem como a relação existente entre o Conselho e a independência e responsabilização do Judiciário. 
O capítulo quarto trata especificamente da competência disciplinar do Conselho Nacional de Justiça e, por esta razão, é consideravelmente mais extenso que os demais. Como será visto, a competência disciplinar do Conselho situa-se num plano polarizado por duas forças - de um lado, a independência judicial; de outro lado, a responsabilização judicial. Além da relação com estes dois princípios, tal competência associa-se ao conceito de accountability, guardando relação, também, com o princípio da publicidade. Após o tratamento destes temas, chega-se ao estudo da natureza da competência disciplinar do Conselho.

No capítulo quinto, com o objetivo de complementar a análise, serão vistos os processos no âmbito do Conselho Nacional de Justiça no exercício de sua competência disciplinar, dando-se destaque para o procedimento administrativo disciplinar previsto na Resolução n. 135/2011, do Conselho Nacional de Justiça. Na sequência, apresenta-se a análise da constitucionalidade de tal Resolução que foi feita no julgamento, finalizado em fevereiro de 2012, da Medida Cautelar na Ação Direta de Inconstitucionalidade n. 4638. Próximo ao final do capítulo, busca-se analisar a competência disciplinar do Conselho Nacional de Justiça tanto à luz de suas próprias decisões, como à luz de algumas decisões do Supremo Tribunal Federal. Por fim, é feita uma breve abordagem acerca da relação entre o Conselho Nacional de Justiça e o Supremo Tribunal Federal.

Feita esta apresentação geral do trabalho, cumpre, neste ponto, apresentar a justificativa da escolha do tema.

Esta se deu, em especial, por duas razões. Em primeiro lugar, objetivou-se estudar um tema que se preocupasse, sobremaneira, com problemas constitucionais atuais e que estivessem relacionados, diretamente, às peculiaridades da sociedade contemporânea. Um tema que, embora predominantemente jurídico, não se mostrasse desconectado da realidade. O tema se justifica, também, pela escassez ${ }^{7}$, em nosso país, de estudos a ele dedicados, ainda mais ao se considerar a ausência de uma sistematização, de enfoque acadêmico, da jurisprudência dos tribunais superiores acerca da atuação do Conselho Nacional de Justiça.

O tema proposto se mostra relevante porque se situa em um campo em que se intersectam os importantes planos da separação de poderes, do federalismo, da

\footnotetext{
${ }^{7}$ Cumpre assinalar que esta escassez se deve, em certa medida, também ao fato de ser relativamente recente a criação do Conselho Nacional de Justiça e, mais recente ainda, a visibilidade alcançada pelo exercício de sua competência disciplinar.
} 
organização dos Poderes em um Estado Democrático de Direito, da interpretação constitucional, cujo conhecimento é indispensável para a construção e a consolidação de uma base teórica sólida, que possibilite o desenvolvimento de futuros trabalhos acadêmicos.

Em síntese, o tema se justifica pelo esforço a ser empreendido para uma melhor compreensão da atuação do Conselho Nacional de Justiça, com a finalidade de fornecer subsídios para o desenvolvimento jurídico do pais, especialmente no âmbito do Poder Judiciário.

Antes de se iniciar o tratamento propriamente dito do tema, cabem alguns esclarecimentos e delimitações conceituais.

De acordo com Luigi Ferrajoli ${ }^{8}$, o Poder Judiciário pode ser definido como o "conjunto dos espaços decisórios - a interpretação das leis, a indução probatória, a conotação equitativa e os juízos de valor discricionários - reservados mais ou menos irredutivelmente à atividade do Juiz". A atividade jurisdicional, por sua vez, entendida como "atividade cognitiva que inclui momentos de valoração e de definição", tem como elemento caracterizador a "sujeição somente à lei", sujeição esta que se exprime no "requisito da imparcialidade, e tem sua justificação ético-política" nos valores "busca da verdade" e "tutela das liberdades". 9

Tendo estas definições como premissas válidas, pode-se verificar que a atividade-fim do Poder Judiciário é a atividade jurisdicional. Deve-se ter, de forma bastante clara, que a atividade jurisdicional, cerne e atividade-fim do Poder Judiciário, difere-se, por sua própria natureza, das demais atividades desempenhadas pelos membros daquele Poder. E este fato gera reflexos na análise do tema - situado no plano da relação existente entre independência e responsabilidade judicial - da competência disciplinar do Conselho Nacional de Justiça. Com efeito, o exercício da competência disciplinar do Conselho só pode ter por objeto a atividade não-jurisdicional dos magistrados. Esta é uma premissa da qual se parte neste trabalho.

Outra importante delimitação é aquela que deve ser feita entre os conceitos de Justiça e de Magistratura.

\footnotetext{
${ }^{8}$ Ferrajoli, 2010, p. 532.

${ }^{9}$ Ferrajoli, 2010, pp. 532-534.
} 
Nesse sentido, tem-se que "o conjunto das instituições judiciárias do país, ou seja, dos órgãos que exercem a jurisdição, compõe o que tradicionalmente se chama Justiça”. A Justiça brasileira é composta por órgãos de superposição - Supremo Tribunal Federal e Superior Tribunal de Justiça, por exemplo -, bem como por diversos organismos chamados "Justiças", cada uma delas com sua estrutura própria. A Justiça, assim considerada, é una e inteiramente contida no Poder Judiciário. É importante ressaltar que o vocábulo Justiça, grafado com inicial maiúscula, não se confunde com justiça, que é o predicado daquilo que é justo ${ }^{10}$. A Magistratura, por sua vez, consiste no "conjunto das pessoas investidas nos órgãos judiciários, ou seja, o conjunto de juízes do país”. Assim conceituada, esta se confunde com a categoria profissional dos juízes. Dessa forma, tem-se que, enquanto "Justiça é um conceito ligado ao serviço público consistente no exercício da função jurisdicional, Magistratura exprime o conglomerado humano dos sujeitos que ocupam os cargos e atuam como agentes do Estado". ${ }^{11}$

\footnotetext{
${ }^{10}$ Dinamarco, 2009, p. 360.

${ }^{11}$ Dinamarco, 2009, pp. 360-361.
} 


\section{CAPÍTULO I}

\section{CONTEXTUALIZAÇÃO DA CRIAÇÃO DO CONSELHO NACIONAL DE JUSTIÇA}

\section{1. Considerações Iniciais}

A contextualização da criação do Conselho Nacional de Justiça é fundamental para o estudo de sua competência disciplinar, pois foi a conjuntura do Poder Judiciário no momento pré-Reforma do Judiciário que ensejou as transformações levadas a efeito pela Emenda Constitucional n. 45/2004.

Utilizando uma analogia, pode-se dizer que, para o correto tratamento de uma doença - conjunto de sinais e sintomas apresentados por um organismo - é necessário conhecer quais são os sinais e sintomas. É necessário, portanto, fazer um diagnóstico daquele organismo para se prescrever um remédio que seja o mais adequado possível.

Sob esta perspectiva, o conhecimento das condições pretéritas e atuais é muito importante para a construção do futuro - trata-se de um olhar para trás. Nesse sentido, Fernanda Flurh ${ }^{12}$ avalia que a criação do Conselho Nacional de Justiça está diretamente ligada às discussões sobre a necessidade de reforma do Poder Judiciário, ponderando que "as constantes preocupações com a lentidão processual e com casos de corrupção, nepotismo e desmandos administrativos estimulavam a ideia de criação de uma instância, órgão ou conselho de controle".

Por outro lado, é igualmente importante um outro ponto de vista, que considere a situação em que se quer chegar, os objetivos a serem alcançados - tem-se, agora, um olhar para frente. Inserida nesta segunda perspectiva está a afirmação de Maria Tereza Sadek ${ }^{13}$, para quem uma das formas de se examinar as propostas de reforma do sistema de justiça é a partir de suas metas.

\footnotetext{
${ }^{12}$ Flurh, 2011, p. 242.

${ }^{13}$ Sadek, 2001, p. 177.
} 
Por isso, neste primeiro capítulo, será feito um breve diagnóstico da situação do Poder Judiciário antes da Reforma de 2004, seguido de um relato dos principais acontecimentos relativos à elaboração da Emenda Constitucional n. 45/2004, sempre com o enfoque para o tema da competência disciplinar do Conselho Nacional de Justiça.

Ao final, será realizada uma abordagem acerca de alguns Conselhos de Justiça no Direito Comparado, com o objetivo de contextualizar seus surgimentos, apontando-se as eventuais semelhanças e diferenças em relação ao Conselho Nacional de Justiça brasileiro.

\section{2. O momento pré-Reforma do Judiciário: breve diagnóstico da situação do Poder Judiciário brasileiro antes de 2004}

Em diagnóstico feito por Dalmo Dallari, no ano de 1996, avaliou-se que os três Poderes que compõem o aparato governamental dos Estados atuais "estão inadequados para a realidade social e política contemporânea". ${ }^{14}$

Em análise voltada ao Poder Judiciário, José Renato Nalini afirmou que "comparativamente aos demais poderes, a Justiça é considerada a mais disfuncional dentre as tarefas confiadas ao Estado", apontando que "ela é lenta demais, inacessível aos excluídos, burocratizada, ineficiente e imprevisível"15.

Considerando que tais diagnósticos foram realizados de forma séria e competente - motivo pelo qual são adotados, neste capítulo, como premissas corretas -, já se observa, logo de início, que a situação em que se encontravam, há alguns anos, os Poderes da República no Brasil, em particular o Judiciário, não era adequada.

Concentrando os esforços no Poder Judiciário - uma vez que o objeto do presente trabalho é a competência disciplinar do Conselho Nacional de Justiça - e esmiuçando a análise feita por Nalini, identificam-se algumas importantes constatações.

\footnotetext{
${ }^{14}$ Dallari, 2008, p. 1. A referência ao ano de 1996 deve-se ao ano da primeira edição da obra do Professor Dalmo de Abreu Dallari.

${ }^{15}$ Nalini, 2004, p. 67.
} 
A primeira delas foi a de que o volume de ações judiciais em curso no Brasil, excessivo e crescente, é “insuportável para o arcaísmo das instituições”. ${ }^{16}$

Além disso, verificou-se que o modelo de Judiciário adotado no Brasil não tem como característica "a adoção de diretivas consensuais", o que "impede a formulação de uma estratégia de ação" e "exclui a possibilidade de se traçar uma política judicial consequente". Num quadro em que há um "descompasso das afirmações das cúpulas", que muitas vezes vivenciam realidades muito distintas, chega-se ao inevitável - e indesejável "personalismo das propostas". ${ }^{17}$

Como resultado de tudo isso, tem-se "uma multiplicação de tribunais, cada qual provido de autonomia administrativa e orçamentária", a funcionar como se fossem “ilhas num arquipélago muita vezes incomunicável”, além da existência de "sistemas não só diferentes, mas verdadeiramente divorciados", bem como da "inexistência de planejamento e insuficiência de critérios administrativos", que são "obrigatórios para o Poder Público". 18

Em um país como o Brasil, de dimensões continentais, com um assimétrico Federalismo composto por muitos - vinte e sete - estados, cada um com o seu Judiciário independente e autônomo, contando ainda com a dualidade de justiça com cinco tribunais federais e mais os tribunais das justiças especializadas (trabalho, eleitoral e militar), é natural que não houvesse uniformidade na administração do Poder Judiciário. ${ }^{19}$

Contudo, esta situação agrava-se considerando-se que a estrutura administrativa seccionada dos Tribunais de Justiça estaduais, "ensimesmados em nome da independência e autonomia federativa", proporcionou, ao longo do tempo, a adoção de costumes e práticas "arraigados numa cultura tradicional e eminentemente local". Com isso, o "modelo de uma justiça estruturada para atender a uma sociedade do século XIX, de economia agrária, patrimonialista, exclusivista e preconceituosa", reproduziu-se para outros estados, e foi se perdurando, com reflexos imediatos na atividade jurisdicional: "morosa, cara, divergente, provocando um desestímulo aos investimentos pela inadimplência e impunidade". ${ }^{20}$

\footnotetext{
${ }^{16}$ Nalini, 2004, pp. 67-68.

${ }^{17}$ Nalini, 2004, pp. 68-69.

${ }^{18}$ Nalini, 2004, pp. 70-72.

${ }^{19}$ Calmon, 2012, sem paginação.

${ }^{20}$ Calmon, 2012, sem paginação.
} 
Dalmo Dallari chama a atenção para uma circunstância muito importante, que é o fato de que "grande parte das deficiências de funcionamento do setor público não decorre de falhas de organização ou de falta de meios, mas se deve a vícios de comportamento", um dos quais é "uma atitude contraditória em relação às leis". ${ }^{21}$ Nesse sentido, acrescenta - e vale o destaque:

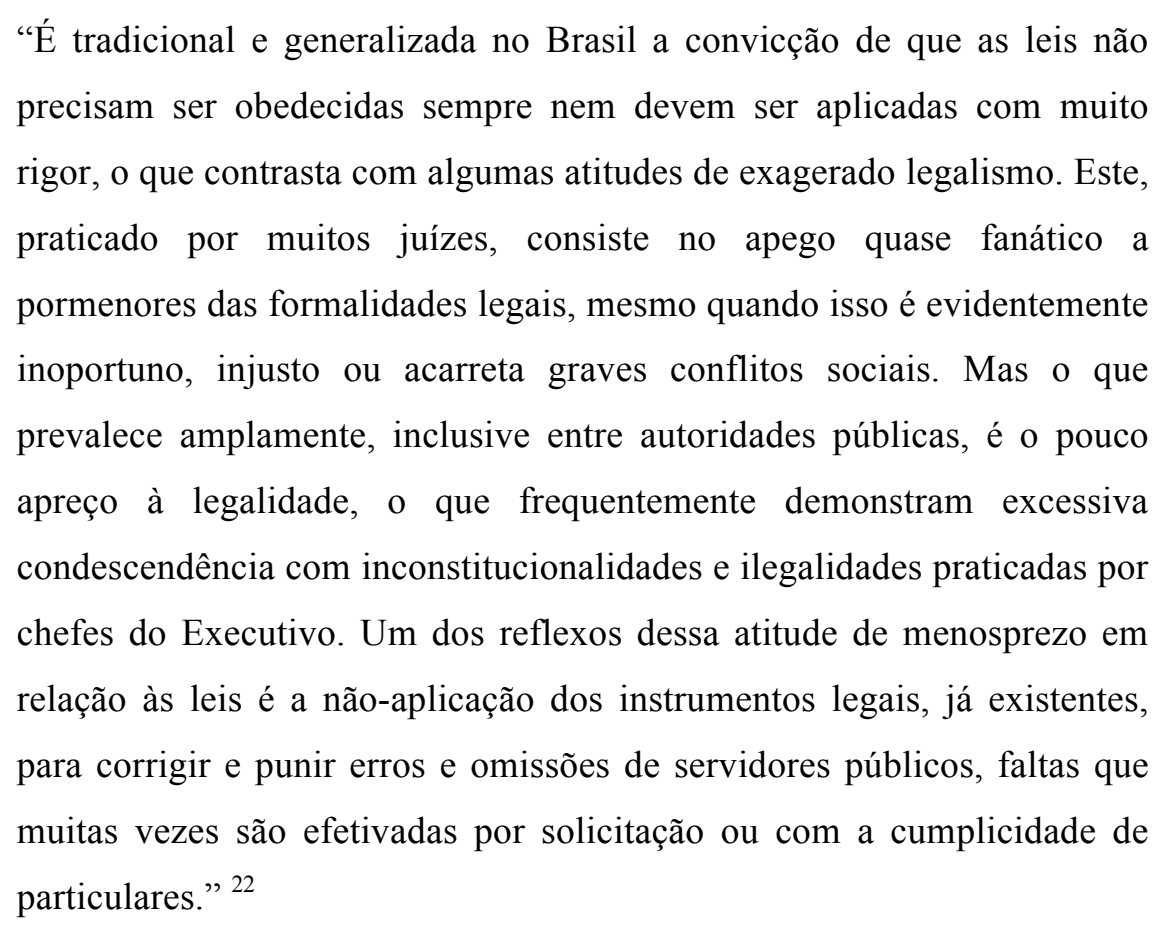

Também alertando para esta situação, Candido Rangel Dinamarco pondera que "não se desconhece que há setores da Justiça brasileira em que a atuação de seus membros tem estado muito abaixo dos padrões desejáveis", tanto sob o prisma da eficiência profissional, como em razão de "comprometimentos incompatíveis com a dignidade do cargo", ou, ainda, por conta de "imprudentes aproximações com litigantes notórios e aceitação de favores espúrios". ${ }^{23}$

Não se pode olvidar, além do mais, de situações em que os próprios magistrados, "por ingenuidade ou leviandade, assumem a condição de cúmplices dos que promovem a desmoralização da magistratura, associando-se a demagogos e corruptos, acobertando ilegalidades de governantes", em troca de vantagens pessoais que não

\footnotetext{
${ }^{21}$ Dallari, 2008, p. 3.

${ }^{22}$ Dallari, 2008, p. 3.

${ }^{23}$ Dinamarco, 2009, p. 419.
} 
guardam relação com a melhoria das condições de trabalho dos juízes e tribunais. "Nesses casos, os juízes é que são os principais inimigos da independência da magistratura". ${ }^{24}$

Fato é que, em um espectro conjuntural que vai "de sistemas informatizados que não conversam entre si a denúncias de impunidade quanto às faltas cometidas por magistrados no exercício de atividades jurisdicionais e administrativas", o sistema de autogoverno do Judiciário mostrou-se "incapaz de atender aos reclamos sociais por um sistema judiciário célere, eficiente e seguro". 25

Em síntese, tem-se que a noção de administração da justiça no Brasil, antes da criação do Conselho Nacional de Justiça, era bastante limitada. Exemplos para ilustrar esta situação não faltam: não constituía disciplina nas escolas da magistratura, nem como instrumento de atualização dos magistrados; não era compartilhada entre os órgãos da própria estrutura judiciária, sendo cada tribunal responsável pela sua própria gestão; a administração de cada órgão passava por mudanças em um curto espaço de tempo, sem uma mínima continuidade, dificultando um planejamento estratégico ${ }^{26}$.

Por tudo isso é que, no século XXI, a administração da Justiça passou a ocupar espaço central nos debates sobre o papel dos tribunais. Publicidade, eficiência e responsabilização passaram a ser preocupações não apenas do Executivo ${ }^{27}$, mas também dos membros do Poder Judiciário enquanto agentes públicos de especial relevo no trato do espaço republicano ${ }^{28}$.

De acordo com o Ex-Ministro do Supremo Tribunal Federal Nelson Jobim" $^{29}$, as "condições históricas que deram lugar ao juiz burocrata e civilmente irresponsável desapareceram" e "foram substituídas por outras", que "impuseram a atualização dos mecanismos de responsabilização e controle da magistratura”. Tal fato é decorrência da extraordinária revalorização da função judicial, nos últimos cinquenta anos, tendo em vista seu crescimento ${ }^{30}$ na sociedade moderna de tipo liberal-democrático. Esta

\footnotetext{
${ }^{24}$ Dallari, 2008, pp. 47-49.

${ }^{25}$ Chimenti, 2005, p. 140.

${ }^{26}$ Guerra, 2010, p. 50, em referência a Freitas, 2006.

${ }^{27}$ E nesse ponto vale a menção à reforma gerencial por que passou o aparato estatal brasileiro na década de 1990, impulsionada, sobretudo, no campo normativo, pela a Emenda Constitucional n. 19, de 1998.

${ }^{28}$ Guerra, 2010, p. 50.

${ }^{29}$ Jobim, 2012, sem paginação.

${ }^{30}$ São causas deste crescimento, segundo Nelson Jobim (2012, sem paginação): “a) a emergência do Welfare State: a expansão da competência dos Poderes Executivo e Legislativo determinou a expansão dos controles pelo Poder Judiciário; b) a imprecisão e ambiguidade dos textos legislativos, decorrentes de compromissos dilatórios entre forças políticas díspares (chamados de "compromissos não autênticos ou apócrifos" por Carl Schmitt); há uma proliferação de legislação aberta, propiciando o aumento da discricionariedade judicial e o
} 
expansão da magistratura e dos poderes processuais substanciais dos juízes trouxe consigo o problema de "sua responsabilidade perante o corpo social - accountability (dever de prestar contas)".

A importância de um controle administrativo é enfatizada também por Celso Antônio Bandeira de Mello, para quem, no Estado de Direito, a Administração Pública submete-se a múltiplos controles ${ }^{31}$, "no afã de impedir-se que desgarre de seus objetivos, que desatenda as balizas legais e ofenda interesses públicos ou particulares". ${ }^{32}$

Um dos pontos mais relevantes deste diagnóstico do Poder Judiciário no momento pré-Reforma reside na visível inação do poder disciplinar exercido no âmbito deste Poder, o qual se concentrava nos órgãos diretivos de segundo grau, e muitas vezes rompia-se a imparcialidade. $^{33}$

Em decorrência dessa inação, houve uma perda significativa da credibilidade nas corregedorias judiciais e na própria lisura da prestação jurisdicional, ante a impunidade de ilícitos funcionais graves ou na punição mais retórica do que prática. ${ }^{34}$

Uma das causas para esta perda de credibilidade das corregedorias é o fato de que elas têm, tradicionalmente, papel eminentemente disciplinar e, por razões culturais, "a proximidade da autoridade correcional com os inspecionados leva a um certo afrouxamento comportamental”. Uma agravante, no âmbito do Judiciário, é "o fato de seus integrantes, além de próximos, terem convivência longa, o que contribui para mais se acentuar a inação, tornando o poder disciplinar das corregedorias quase inócuo”, com

desenvolvimento de uma nova concepção sobre o trabalho interpretativo do juiz - uma espécie de "poder legislativo supletivo"; c) a natureza "promocional" dos direitos sociais, o que importa em decidir se determinada atividade estatal, ou sua inércia, está alinhada com os programas prescritos de forma vaga na legislação social; d) a massificação das demandas judiciais (Class action; Public interest litigation; Actions Collectives; Verbandsklagen e a tutela judiciária dos interesses difusos); e) a autonomia em relação ao Poder Legislativo, decorrente do estabelecimento de uma supralegalidade constitucional e da crise da lei, como fonte primária do ordenamento jurídico. A magistratura não mais se limita à interpretação e aplicação da lei, mas realiza, também, sua fiscalização, seja de forma difusa e em concreto (Estados Unidos e Brasil), seja de forma concentrada e em abstrato (Brasil, Alemanha, Áustria); f) o autogoverno da magistratura, com autonomia em relação ao Poder Executivo e independência do juiz; g) a politização de alguns setores da magistratura; h) a ampliação dos poderes de direção processual do juiz (redução do princípio dispositivo no processo); i) a crise da Justiça (falta de meios; atrasos inimagináveis; falta de formação; necessidade de especialização)".

${ }^{31}$ Bandeira de Mello, 2004, p. 825. Tais controles, prossegue Bandeira de Mello, "envolvem quer aspectos de conveniência e oportunidade, quer aspectos de legitimidade".

32 Bandeira de Mello, 2004, p. 825. O Professor Celso Antônio Bandeira de Mello leciona, em complemento, que "o controle externo [da Administração Pública] compreende o controle parlamentar direto, o controle exercido pelo Tribunal de Contas (órgão auxiliar do Legislativo nesta matéria) e o controle jurisdicional."

${ }^{33}$ Calmon, 2012, sem paginação.

${ }^{34}$ Flurh, 2011, p. 80. 
efeito deletério para a carreira: "a falta de repressão à indisciplina é porta aberta para seguidores do mau exemplo." 35

Além disso, há um dado muito importante geralmente desconhecido: "as competências das Corregedorias-Gerais são estabelecidas nos Regimentos Internos dos tribunais e estes quase nunca autorizam o Corregedor a fiscalizar os atos dos membros do tribunal, mas apenas dos juízes de nível inferior”. Assim, “como é evidente, a omissão de controle é total quanto aos atos dos dirigentes dos tribunais". 36

No julgamento da Ação Direta de Inconstitucionalidade n. 3367, é possível entrever, nos votos de vários dos Ministros do Supremo Tribunal Federal, a constatação de que o controle disciplinar, quando ocorre, consiste em agir sobre os juízes de primeiro grau (de cima para baixo) e não nos próprios Tribunais.

Durante os debates que ocorreram ao longo do julgamento da referida Ação Direta de Inconstitucionalidade, mais precisamente por ocasião do voto do Ex-Ministro Carlos Velloso, o Ex-Ministro Ayres Britto vislumbrou, no relato do magistrado Vladimir Passos de Freitas, o que pareceu ao Ministro uma grande e justa preocupação daquele autor com o corporativismo do Judiciário:

\begin{abstract}
"As infrações administrativas praticadas por um magistrado de segunda instância devem ser apuradas no próprio tribunal onde ele exerce as suas funções. A apuração nem sempre é fácil. A convivência durante anos, a aproximação das famílias, a solidariedade nos momentos difíceis de vida, tudo isso cria vínculos fortes. É exigir demais, ainda que não seja impossível, que um colega investigue a falta funcional praticada por outro. (...) Disso resulta que pouco se faz em tal sentido." ${ }^{37}$
\end{abstract}

É necessário que se reconheça que a diversidade de gestão e a indisciplina administrativa deixavam isolados os tribunais, principalmente os estaduais. A Justiça Federal contou, desde a sua recriação em 1967, com o Conselho da Justiça Federal,

${ }^{35}$ Calmon, 2012, sem paginação.

${ }^{36}$ Dallari, 2008, p. 47.

${ }^{37}$ Freitas, 2003, p. 35; o trecho foi utilizado no voto do Ex-Ministro Ayres Britto, no julgamento da ADI 3367. Nessa mesma obra, Freitas (2003, p. 36) resume a questão do controle disciplinar em segundo grau: "em suma, o que se pode concluir é que o controle interno da Magistratura de segundo grau (...) é muito frágil. Ao contrário da primeira instância, sujeita a permanente fiscalização, os magistrados de segundo grau não possuem, em realidade, qualquer tipo de controle". 
incumbido de uniformizar as práticas administrativas, estabelecer unidade nos benefícios concedidos, traçar as regras a serem seguidas pelos magistrados e servidores, compatibilizando-as com a legislação federal. As Justiças Especiais, por sua vez, tinham como elemento uniformizador os Tribunais Superiores (Tribunal Superior do Trabalho, Superior Tribunal Militar e Tribunal Superior Eleitoral), que direcionavam as práticas administrativas, estabeleciam limites e exigiam o cumprimento da legislação federal. "Faltava, portanto, um órgão centralizador de gestão para a Justiça Estadual". ${ }^{38}$

Ainda com relação ao poder disciplinar administrativo, após a Constituição da República de 1988, no momento pré-Reforma do Judiciário, "não havia um adequado sistema de controle disciplinar administrativo dos juízes, pois não foram concedidos os incentivos suficientes para que os magistrados buscassem seguir da melhor maneira possível os deveres funcionais". Além disso, "não se estabeleceu um mecanismo de accountability horizontal", uma vez que inexistia um agente estatal, a não ser os próprios tribunais, para conhecer ou rever aspectos disciplinares dos magistrados. ${ }^{39}$

Não se pode negar que o problema do controle administrativo e disciplinar dos juízes é consideravelmente delicado. Muitas vezes não porque um juiz que cometeu uma infração passível de sanção não é punido, mas sim porque não se divulga ou não se permite sua conveniente divulgação, dando a sensação de corporativismo ou falta de transparência. ${ }^{40}$

Dessa maneira, o controle disciplinar acabava por ter um indesejado viés corporativo, além de ser pouco transparente. Isso não significa, necessariamente, uma garantia de impunidade. Contudo, não deixa de ser grave, pois, muitas vezes, nem mesmo quem solicitou alguma providência é informado adequadamente sobre o resultado do pedido. De qualquer forma, falta uma atividade mais constante de vigilância - permitindose, obviamente, a ampla defesa do juiz - para que as irregularidades sejam devidamente apuradas. $^{41}$

\footnotetext{
${ }^{38}$ Calmon, 2012, sem paginação.

${ }^{39}$ Robl Filho, 2012, p. 242.

${ }^{40}$ Gomes, 1993, p. 34.

${ }^{41}$ Gomes, 1993, p. 34.
} 


\section{3. A necessidade de reforma do Poder Judiciário}

Diante desse quadro apresentado, Luiz Flávio Gomes apresentou um diagnóstico - "o que está faltando na estrutura do Poder Judiciário brasileiro é a criação de um conselho nacional da magistratura", e um remédio - "que deve encarregar-se, precipuamente, das tarefas de controle disciplinar de todos os juízes do país ${ }^{42}$, e de [avaliação da] qualidade do juiz e do serviço prestado por todos os órgãos jurisdicionais". Este órgão teria competência também para supervisionar os atos administrativos praticados pelos Tribunais, bem como os atos de gestão orçamentária. Ademais, "por ser um órgão idealizado para unificar a política judicial em todo país, é evidente que ainda lhe caberia encarregar-se da atividade correcional, sem prejuízo da exercida pelos órgãos censórios já existentes nos vários setores da Justiça." 43

O caráter administrativo deste órgão nacional de controle proposto por Luiz Flávio Gomes ${ }^{44}$ já era acentuado, na medida em que deveria competir-lhe receber "as reclamações contra as atividades administrativas dos juízes e tribunais, assim como contra a qualidade do serviço judicial prestado, excluindo-se a estrita atividade jurisdicional, que já está sujeita ao controle recursal". E esse controle se daria com a supervisão dos juízes pelos Tribunais, encarregando-se o Conselho Nacional de controlar, diretamente, os Tribunais e, indiretamente, todos os juízes, “mas sempre no que diz respeito ao âmbito administrativo". 45

Destacava-se, também, a função disciplinar deste Conselho Nacional de Magistratura idealizado por Luiz Flávio Gomes, a desempenhar as atividades de "controle e disciplina dos juízes - originariamente ou em grau de recurso". ${ }^{4}$

\footnotetext{
${ }^{42}$ Luiz Flávio Gomes (1993, p. 36) acrescenta que esse controle seria originário em relação aos juízes de tribunais e em grau de recurso em relação aos juízes de primeiro grau.

${ }^{43}$ Gomes, 1993, pp. 36-37.

${ }^{44}$ Gomes, 1993, p. 38: “A composição desse órgão de controle, no entanto, para não incorrer em flagrante inconstitucionalidade e para preservar a independência do Judiciário, não pode contar com nenhum membro alheio aos seus quadros. (...). A delicada questão disciplinar dos juízes, de outro lado, encontraria melhor equacionamento, embora ainda ficasse restrita ao próprio Judiciário. Para quebrar o risco do corporativismo, e considerando que nenhum órgão dentro do Estado de Direito pode ficar sem controle, os membros do Conselho Nacional de Magistratura devem estar sujeitos ao impeachment, tal como os Ministros do Supremo Tribunal Federal, o que permitiria, em última análise, um certo controle do Legislativo.”

${ }^{45}$ Gomes, 1993, p. 37, sem destaque no original.

${ }^{46}$ Gomes, 1993, p. 76. Luiz Flávio Gomes acrescenta, neste ponto que, "de todas as funções dos órgãos de governo e de controle, uma possui particular e especial importância: é a que consiste em apurar a responsabilidade dos membros do próprio Poder Judiciário, aplicando as sanções cabíveis”.
} 
$\mathrm{Na}$ apresentação da monografia de Luiz Flávio Gomes - “A questão do controle externo do Poder Judiciário" - Sergio Jacintho Guerrieri Rezende, à época 1993 - Presidente da Associação Paulista de Magistrados, apresentava o seguinte quadro para a Magistratura Nacional, mais especificamente sobre a necessidade de uma reforma do Judiciário:

\begin{abstract}
"A questão do controle do Poder Judiciário precisa ser debatida, e quem tem que assumir a liderança deste debate é o próprio Juiz. Se não tomarmos essa iniciativa agora, poderemos ser surpreendidos por decisões externas que não levam em conta a real situação do Judiciário nem contemplem os anseios da Magistratura. Não podemos ficar alheios a esse debate, sob pena de sermos marginalizados no processo de reforma constitucional. Qualquer tipo de controle "externo" compromete a independência do Juiz e do Judiciário. (...) Urge uma campanha de esclarecimento público sobre a verdadeira situação da Justiça. Seu anacronismo não deriva da culpa dos Juízes, mas de uma estrutura quase centenária que se mantém praticamente inalterada até os dias de hoje. O problema da Justiça não é propriamente de controle, embora se deva pensar no aprimoramento do sistema atual, mas de estrutura. Falta uma base informatizada, faz-se necessária a descentralização do direito processual, faltam meios materiais e humanos, a autonomia do Judiciário ainda é puramente formal, os Juizados Especiais precisam funcionar rapidamente para acelerar a prestação jurisdicional, o acesso à Justiça precisa ser ampliado etc. No Brasil, no entanto, tradicionalmente, não se investe na Justiça, apenas cobra-se sua eficiência. Precisamos realmente de um Judiciário forte, mas não é com controle 'externo' que isso poderá ser alcançado. $" 47$
\end{abstract}

Também no ano de 1993, prefaciando tal obra de Luiz Flávio Gomes, Francisco de Paula Xavier Neto, então Presidente da Associação dos Magistrados Brasileiros, apontava que

\footnotetext{
${ }^{47}$ Gomes, 1993, apresentação feita por Sergio Jacintho Guerrieri Rezende.
} 
"deve ficar muito claro que o organismo de controle externo, se for considerado necessário, tem que preservar a natureza inerente ao Judiciário - ser técnico, sereno, criterioso, discreto, objetivo, de modo nenhum político no sentido pouco feliz que se empresta ao termo em nosso país." $" 48$

Por fim, Luiz Flávio Gomes propunha que se deixasse a cargo do legislador complementar o tratamento de "detalhes da sua composição e atribuições", mas ressalvava que as resoluções do Conselho deveriam ter "caráter imperativo, pois do contrário será criado um órgão meramente decorativo". 49

O depoimento na audiência pública na Comissão de Reforma do Judiciário, em 28/4/99, do então presidente do Superior Tribunal de Justiça, Ministro Antonio Pádua Ribeiro, retrata com muita percuciência a situação do controle disciplinar no âmbito do Poder Judiciário, bem como vislumbra as alterações necessárias:

"Vou explicar como funcionará. Já temos controle do Poder Judiciário, exercido pelas corregedorias e pelos próprios tribunais. Mas há defeitos nesse controle. E quais esses defeitos? Hoje, punir desembargador, punir Ministro é quase impossivel. Para isso, precisamos alterar o texto constitucional. Como? Sustento o seguinte: há certas punições que são risíveis, por exemplo, aposentadoria e disponibilidade com vencimentos integrais. Isso é um absurdo, deve ser mudado imediatamente, não há dúvida; é indiscutível. Ademais, dever-se-ia abrir o texto constitucional para permitir a punição do juiz por falta de decoro e por falta de trabalho. Isso precisa ser feito. Falo de punição administrativa, de forma que é preciso ter-se cuidado: essas punições, com a perda do cargo, não podem, em todos os casos, ser aplicadas pelo tribunal ao qual o juiz está submetido, pois as relações entre juiz de primeiro grau e o tribunal são relações de simpatia e de antipatia, e a vitaliciedade é uma garantia da imparcialidade do juiz. O juiz decide contra poderosos, contra o poder econômico e o poder político, de modo que essa e outras garantias constitucionais são fundamentais. Tenham os senhores a certeza de que

\footnotetext{
${ }^{48}$ Gomes, 1993, prefácio feito por Francisco de Paula Xavier Neto.

${ }^{49}$ Gomes, 1993, p. 41. Sobre o poder normativo do Conselho Nacional de Justiça, serão lançadas breves notas no Capítulo II deste trabalho.
} 
só a existência desse Conselho, com as alterações constitucionais sugeridas, irá estimular o funcionamento dos outros órgãos de controle existentes e, na eventualidade de não funcionarem estes, aquele avocará $o$ processo. Já fui membro do Conselho de Justiça Federal e posso testemunhar-lhes que vi muitos problemas serem resolvidos só com telefonemas: reclamava-se contra o juiz, o corregedor the telefonava, e muitas vezes, a dificuldade era resolvida sem desgaste para o juiz ou para a Justiça. Creio que, com a criação de um órgão pequeno - grandes estruturas não funcionarão - e com a modificação constitucional - há que se alterar o texto constitucional prevendo punição por falta de decoro e de trabalho, o sistema será oxigenado e melhorado, e poder-se-ão evitar os absurdos que acontecem. Este Conselho não deveria ter apenas função de punir, mas também de ditar a política do Poder Judiciário, a política orçamentária, as diretrizes do Poder, enfim, outras funções também importantes". ${ }^{50}$

Evidenciando também a necessidade de reforma do Judiciário, José Renato Nalini ponderava que um órgão nacional de administração do Judiciário "talvez corrigisse distorções, pois há regiões com atendimento satisfatório da Justiça e outras carentes de recursos humanos". Com isso, poder-se-ia "comprovar, ou não, a alegada necessidade de imediata multiplicação do número de juízes e funcionários". Ademais, tal órgão "permitiria o estabelecimento de um módulo de produtividade, seja para magistrado, seja para unidade judicial", conferindo "a isonomia possível entre prestadores de serviço ontologicamente idêntico". 51

Dalmo Dallari, também apontando para a necessidade de transformação da estrutura e dos hábitos do Poder Judiciário, enfocava um outro ponto importante, qual seja, a necessidade de se conferir maior transparência aos atos de gestão do Poder Judiciário. Com efeito, para Dallari, "para que o povo respeite verdadeiramente o Judiciário" é necessário que este Poder apresente, com clareza e transparência, por meio do "fornecimento de informações precisas e de modo facilmente compreensível aos principais

\footnotetext{
${ }^{50}$ Sadek, 2001, pp. 124-127. Sem destaque no original.

${ }^{51}$ Nalini, 2004, pp. 67-69.
} 
órgãos da imprensa", quais são "suas rendas e de que modo são gastos os recursos que lhe são destinados". 52

Nessa mesma linha de raciocínio, José Afonso da Silva defendia a necessidade de "um órgão para o exercício de certas funções de controle administrativo, disciplinar e de desvios de condutas da Magistratura, como é previsto em Constituições de vários países". Tal órgão seria "benéfico à eficácia das funções judiciais, não só por colaboração na formulação de uma verdadeira política judicial como, também, porque impede que os integrantes do Poder Judiciário se convertam num corpo fechado e estratificado". Sob outro aspecto, não se pode negar que poderia contribuir "para dar legitimidade democrática aos integrantes do Poder Judiciário, cuja investidura não nasce da fonte primária da democracia, que é o povo",53.

Sob outra perspectiva - da necessidade de implementação de mecanismos de accountability $^{54}$ pelo Poder Judiciário brasileiro - Ilton Robl Filho aponta para a necessidade de se resolver o problema da eficiência judicial, além da carência de instrumentos de accountability dos agentes estatais em geral e de accountability judiciais institucional e comportamental. ${ }^{55}$

Dessa forma, e levando em consideração o que foi exposto até aqui, fica clara a necessidade de uma reforma do Poder Judiciário, especialmente no que se refere à criação de um órgão de administração, planejamento e controle.

Como indica José Afonso da Silva ${ }^{56}$, já no ano de 1854, o Ministro Joaquim Nabuco, havia pensado uma profunda reforma do Judiciário, que não foi, contudo, levada a efeito, pelo menos no sentido de se criar um órgão do Poder Judiciário com atribuições de planejamento e controle.

Posteriormente, no século XX, sobretudo a partir da década de 1970, ocorreram dois movimentos, em certa medida, complementares: de um lado, fortaleceramse os argumentos a favor da criação de um órgão para exercer o controle externo, acentuando-se os limites de sua intervenção; e, de outro, houve uma considerável

\footnotetext{
${ }^{52}$ Dallari, 2008, p. 153.

${ }^{53}$ Silva, 2006, p. 593; no mesmo sentido, Silva, 2005, pp. 567-568.

${ }^{54}$ Uma análise acerca da accountability como função do Conselho Nacional de Justiça será apresentada no Capítulo IV, no item em que se estuda a relação existente entre o conceito de accountability e a competência disciplinar do Conselho.

${ }^{55}$ Robl Filho, 2012, p. 243.

${ }^{56}$ Silva, 2006, p. 502.
} 
diminuição no grau de resistências à criação de uma instituição com poderes de supervisionar a magistratura. ${ }^{57}$

Este fato é mais perceptível ao se analisar a década de 1990. Enquanto no início dos anos 90 "temia-se que um organismo dessa natureza pudesse ferir de morte a independência entre os Poderes e a autonomia do Judiciário", no final da década "os argumentos dominantes passaram a sublinhar o caráter democrático e republicano desta inovação". Do mesmo modo, "aumentaram as manifestações de apoio, até mesmo no interior da Magistratura". 58

Nesse sentido, é interessante notar que, em pesquisa realizada em 1993, $86,5 \%$ dos juízes avaliavam negativamente a proposta de criação de órgão de controle externo do Poder Judiciário, ao passo que, em 2000, este percentual foi reduzido para $25,5 \%{ }^{59}$

Com um cenário mais favorável, tanto por condições internas ao Poder Judiciário, como por condições externas àquele poder - em especial uma maior maturidade político-institucional no Brasil - surge um novo discurso de Reforma do Poder Judiciário, revestido de caráter democrático, em que se sustentava a necessidade de se instituir um verdadeiro e efetivo autogoverno dos juízes, e se defendia, como exigência inafastável do Estado de Direito e garantia dos direitos fundamentais, a independência plena do Poder Judiciário.

Dessa forma, conclui-se que o surgimento do atual Conselho Nacional de Justiça está relacionado com as discussões sobre a necessidade de reforma do Judiciário e à própria ideia de controle externo deste Poder. "As constantes preocupações com a lentidão judiciária e com as notícias de corrupção, nepotismo e desmandos administrativos estimulavam a ideia de criação de uma instância, órgão ou conselho de controle". ${ }^{6}$

É importante que se esclareça que são muitas as reformas de que o Judiciário necessita, indo desde pormenor da mudança de condições materiais de trabalho até a atualização da mentalidade de seus membros. ${ }^{61}$

\footnotetext{
${ }^{57}$ Sadek, 2001, p. 92.

${ }^{58}$ Sadek, 2001, p. 93.

${ }^{59}$ Sadek, 2001, p. 112.

${ }^{60}$ Flurh, 2011, p. 67.

${ }^{61}$ Dallari, 2008, p. 8.
} 
Com efeito, "uma reforma que se resuma à alteração do texto constitucional é insuficiente para converter a Justiça no serviço público célere, eficiente e acessível". Uma verdadeira reforma da Justiça instituiria "um modelo unificado, homogeneidade de administração, observância de um planejamento", conferiria "racionalidade e eficácia a esse poder estatal hoje pulverizado e desprovido de condições até mesmo de disseminar as boas experiências". ${ }^{2}$

A criação de estruturas institucionais no âmbito do Poder Judiciário, é importante ponderar, constitui apenas "o primeiro eixo do salto qualitativo essencial à reformulação da Justiça. Há um segundo eixo, que é o capítulo das alterações legislativas. E um terceiro eixo, que independe de Emenda à Constituição ou modificação de lei. Depende apenas da consciência de cada operador". ${ }^{63}$

\section{4. A Emenda Constitucional n. 45, de 30 de dezembro de 2004.}

Inserido no art. 103-B da Constituição da República, por meio da Emenda Constitucional n. 45, de 30 de dezembro de 2004, o constituinte derivado criou o Conselho Nacional de Justiça como órgão do Poder Judiciário, atribuindo-lhe competência de controlar a atuação administrativa e financeira do próprio Poder ao qual pertence, assim como a competência de controle do cumprimento funcional dos juízes.

O Conselho Nacional de Justiça surgiu em um contexto de inúmeros questionamentos, de naturezas as mais diversas, como por exemplo, sua composição, a forma de indicação de seus membros e o rol de suas competências.

Um importante foco de críticas direcionava-se à inexistência de controle semelhante no âmbito do Executivo e do Legislativo, bem como às implicações que geraria no federalismo brasileiro, tendo em vista que se defendia a existência de um controle uno para a magistratura da União e dos Estados.

\footnotetext{
${ }^{62}$ Nalini, 2004, p. 70.

${ }^{63}$ Nalini, 2004, pp. 70-71.
} 
Um ponto muito controvertido sempre foi o da instituição de um controle externo do Poder Judiciário. ${ }^{64}$ Luiz Flavio Gomes ${ }^{65}$, por exemplo, temia que os conselhos externos, mais que órgão de governo $d a$ Magistratura, representassem, na realidade, órgãos do Governo na Magistratura. ${ }^{66}$

Desde antes da Emenda Constitucional n. $7 / 1977^{67}$, pela que se instituiu o Conselho Nacional da Magistratura no art. 112 da Constituição de 1967/1969, questionavase a necessidade - e a constitucionalidade - de um órgão do próprio Poder Judiciário para disciplinar o comportamento dos magistrados, debatendo-se a tese da independência do Judiciário.

O Conselho Nacional da Magistratura era um órgão com jurisdição em todo território nacional, formado integralmente por Ministros do Supremo Tribunal Federal, num total de sete membros, sendo estes indicados pela própria Corte, por meio de votação nominal, com mandato de dois anos. O Procurador-Geral da República também oficiava perante o Conselho.

A Lei Complementar n. 35/1979 - Lei Orgânica da Magistratura Nacional disciplinava infraconstitucionalmente a estrutura e o funcionamento do Conselho. Sua atribuição principal era de natureza correcional, desempenhando atividades como o conhecimento de reclamações contra membros de tribunais e a condução de processos disciplinares contra juízes de primeira instância, podendo, nesta hipótese, determinar a disponibilidade ou a aposentadoria com vencimentos proporcionais ao tempo de serviço.

José Adércio Leite Sampaio, traçando o perfil das atribuições do Conselho Nacional da Magistratura, esclarece que “o Conselho era feito de papel e de intenção". Isso porque se dizia que seu objetivo era unificar o sistema da magistratura estadual e federal, além de evitar atos de insubordinação administrativa e de corrupção. ${ }^{68}$ No entanto, o principal objetivo do Conselho - o controle das instâncias inferiores e estaduais da justiça - não foi atingido em razão da falta de abertura política, permanecendo o Judiciário sem a interferência do Conselho, aprofundando vícios e corporativismos antigos e, de certo

\footnotetext{
${ }^{64}$ Registre-se a ressalva de José Afonso da Silva (2006, p. 593; no mesmo sentido, Silva, 2005, pp. 567-568) para o fato de que "esta expressão [controle externo do Poder Judiciário] peca por sua má significação", pois "transmite a ideia de que o Poder Judiciário seria controlado por um órgão externo", o que "seria inconcebível, porque, então, este órgão externo é que seria o Poder.

${ }^{65}$ Luiz Flávio Gomes aponta aproximadamente 70 textos publicados no período entre 1988 e 1993 acerca do controle externo da Magistratura. Cf. Gomes, 1993, pp. 32-33.

${ }^{66}$ Gomes, 1993, p. 23.

${ }^{67}$ Editada com base no Ato Institucional n. 5/1968.

${ }^{68}$ Sampaio, 2007, p. 240.
} 
modo, exercendo as suas competências constitucionais com a autonomia permitida pelo tempo. ${ }^{69}$

Com a extinção do Conselho da Magistratura Nacional, que não foi mantido na ordem constitucional pelo legislador constituinte de 1988, a fiscalização disciplinar dos membros dos tribunais foi fortemente abalada na prática.

Apesar de não ter sido incorporada no Texto Constitucional de 1988, a ideia de um órgão de controle do Poder Judiciário ensejou alguns debates antes mesmo da Assembleia Nacional Constituinte, o que levou à inclusão do Conselho Nacional de Justiça no art. 151 do Projeto A de Constituição, elaborado pela Comissão de Sistematização da Comissão liderada por Afonso Arinos. ${ }^{70}$

Contudo, diante das intensas pressões contrárias dos juízes, resultando em constantes embates entre a Magistratura e a Ordem dos Advogados do Brasil, sendo noticiado na imprensa nacional - que se manifestava pela criação de um Conselho fiscalizador - a ideia do Conselho foi fulminada e enterrada no Projeto B da Constituição. E desta forma, valorizando o pleno governo do Judiciário, a Constituição Federal de 1988, obviamente, não abarcou a ideia do Conselho. ${ }^{71}$

Neste ponto, não se pode esquecer um aspecto relativo às origens e à formação do processo constituinte concluído em 1988. O Brasil buscava deixar no passado "um regime autoritário e de restrições de direitos e de liberdades e, enfrentando grave crise política, institucional, social e econômica, almejava reconstruir suas instituições e seus quadros constitucionais e de reconstrução das instituições”. Desse modo, a Constituição da República de 1988 foi “a constituição possível nas circunstâncias da conjuntura política interna", em um cenário de "entrechoque severo de opiniões, carência de hegemonias políticas estruturadas e operantes, e pressões de toda ordem". ${ }^{72}$

De qualquer forma, após a Constituição da República de 1988, foi ganhando cada vez mais corpo e visibilidade a ideia de contenção de eventuais abusos provenientes dos membros do Poder Judiciário, de modificação do "ambiente de desmandos, de improbidades, de nepotismo". Além disso, ficava cada vez mais premente a "necessidade de tornar mais responsável a gestão administrativo-financeira" dos tribunais. Tudo isso

\footnotetext{
${ }^{69}$ Flurh, 2011, p. 67.

${ }^{70}$ Flurh, 2011, p. 67.

${ }^{71}$ Flurh, 2011, p. 67.

72 Jucá, 2005, p. 16.
} 
contribuiu para que não fosse exaurida ideia de controle do Poder Judiciário, a fim de se promover sua reestruturação. $^{73}$

Passada a promulgação da nova Constituição da República, não tardou para terem reinício os debates sobre a criação do Conselho. Isso ocorreu, em primeiro lugar, com a Proposta de Emenda à Constituição n. 96/1992, de autoria do deputado Hélio Bicudo, sendo convertida, em dezembro de 1993, em Proposta de Emenda Revisional. ${ }^{74}$

A Proposta de Emenda à Constituição 96/1992 (PEC 96/1992) ${ }^{75}$ foi aprovada pela Câmara dos Deputados, e trazia um órgão com composição híbrida ${ }^{76}$. O Conselho tal como formado na PEC 96/1992 e aprovado na Câmara dos Deputados, possuía dentre suas atribuições o papel de zelar pela autonomia do Poder Judiciário e pelo cumprimento do Estatuto da Magistratura.

O projeto apresentado pelo Deputado Aloysio Nunes Ferreira em seu relatório sobre a PEC 96/1992 estava baseado em três grandes eixos. O primeiro destes eixos consistia na criação de um órgão de controle externo do Judiciário, com funções administrativas e correcionais. O segundo eixo relacionava-se à criação da súmula vinculante, do incidente de inconstitucionalidade e da arguição de relevância, como medidas de concentração de competências e de centralização da máquina judiciária. $\mathrm{O}$ terceiro eixo, por sua vez, tinha por objeto mudanças no âmbito das justiças especializadas, com destaque para a proposta radical de extinção da Justiça trabalhista. ${ }^{77}$

Analisando os sucessivos relatórios elaborados no âmbito da PEC 96/92, Maria Teresa Sadek $^{78}$ identificou três dimensões principais da Reforma do Judiciário. Pode-se dizer que existe, em primeiro lugar, o problema da jurisdição política constitucional, relativo ao sistema de controle da constitucionalidade das leis. A segunda

\footnotetext{
${ }^{73}$ Flurh, 2011, p. 67.

${ }^{74}$ Flurh, 2011, p. 68, que acrescenta que já àquela época havia algumas vozes, como o então deputado Nelson Jobim, defendendo uma espécie de controle externo do Judiciário.

${ }^{75}$ Um tratamento bem detalhado à questão da tramitação legislativa da PEC 96/92, que deu origem à EC 45/2004, é realizado por Rulli Neto, 2007, em especial pp. 192-199.

${ }^{76}$ Tal composição já previa a existência de 15 membros: Ministro do Supremo Tribunal Federal; Ministro do Superior Tribunal de Justiça; Ministro do Tribunal Superior do Trabalho; desembargador de Tribunal de Justiça e juiz estadual, indicados pelo Supremo Tribunal Federal; juiz de Tribunal Regional Federal e Juiz Federal, indicado pelo Superior Tribunal de Justiça; juiz de Tribunal Regional do Trabalho e juiz do trabalho, indicados pelo Tribunal Superior do Trabalho; membro do Ministério Público da União, indicado pelo Procurador-Geral da República; membro do Ministério Público Estadual, indicado pelo Procurador-Geral da República dentre os nomes indicados pelo órgão competente de cada instituição estadual; dois advogados indicados pelo Conselho Federal da Ordem dos Advogados do Brasil; e dois cidadão de notável saber e de reputação ilibada, indicados pela Câmara e pelo Senado.

${ }^{77}$ Sadek, 2001, p. 18.

${ }^{78}$ Sadek, 2001, pp. 20-21.
} 
dimensão da reforma trata da existência e efetividade de mecanismos de controle e fiscalização dos órgãos do sistema de justiça, especialmente por meio da criação do polêmico Conselho Nacional de Justiça. Já a terceira dimensão contempla os aspectos organizacionais e estruturais segundo sua capacidade de ampliar ou reduzir o acesso à Justiça e a democratização do Judiciário.

Em agosto de 1995, uma Comissão Especial foi constituída para emitir Parecer sobre a Proposta de Emenda Revisional. Entretanto, diversas emendas foram apresentadas na oportunidade, totalizando em torno de quarenta e cinco emendas, sempre com foco de discussão voltado para a composição e as atribuições.

No entanto, o texto aprovado pela Câmara recebeu, já no Senado Federal, diversas outras emendas, quase sempre se debatendo acerca da representação de interesses corporativos, carecendo-se, por vezes, de debates profundos sobre a oportunidade de criação de órgão de efetivo aperfeiçoamento do Judiciário e de prestação devida e efetiva da jurisdição. Mais uma vez, sepultou-se a ideia de controle do Poder Judiciário, arquivando-se a PEC 96/1992.

Frise-se, no entanto, que a instituição do Conselho não se deu de forma fácil. A inserção de tal órgão no âmbito do Poder Judiciário foi alvo de muitas críticas e resistências. Paradoxalmente, não houve muitos debates - sobretudo no meio acadêmico em que se buscassem soluções para os problemas do Judiciário por meio da instituição de um novo Conselho. ${ }^{79}$

A Magistratura, em sua maioria, resistia à ideia do controle, embora alguns de seus membros defendessem-na nos termos idealizado pelo então deputado Nelson Jobim - uma instituição com representação de diversos setores da sociedade, mais ligados ao sistema de justiça, isto em um órgão de composição híbrida, composta essencialmente por integrantes dos tribunais de cúpula ${ }^{80}$.

Para Luiz Flávio Gomes, um equívoco bastante comum de algumas propostas oficiais de Reforma ${ }^{81}$ era a manutenção de uma "verticalização petrificada" do exercício do Poder, consistente na presença constante de Ministros do Supremo e de

\footnotetext{
${ }^{79}$ Sampaio (2007, p. 247) acrescenta ainda que até mesmo a Secretaria criada pelo Ministério da Justiça, intitulada de Secretaria da Reforma do Judiciário, não trouxe discussões profundas sobre a questão, limitando-se a realizar e publicar estudos que justificassem as teses e as propostas do governo.

${ }^{80}$ Sampaio, 2007, p. 243.

${ }^{81}$ De acordo com Flurh (2011, p. 70), diversas foram as propostas de criação de um Conselho Nacional Estatuto da Magistratura, PEC n. 12, de 1991, do Senador Mauricio Correia, proposta do Superior Tribunal de Justiça etc.
} 
Tribunais Superiores, sendo assim, "propostas que sugerem a concentração do poder". Com isso, tratava-se de "propostas, com o devido respeito, feitas para não mudar nada". Um interessante obstáculo, na visão de Luiz Flávio Gomes, consistia no fato de todos os potenciais membros integrantes de um conselho encontrarem-se "atarefadíssimos com seus processos ou encargos atuais" e, por esta razão, sem tempo suficiente "para se dedicar à importante tarefa de controlar efetivamente o Judiciário para aprimorá-lo". 82

Interessante destacar, também, uma preocupação revelada pelo magistrado Ricardo Cunha Chimenti, Juiz do Tribunal de Justiça do Estado de São Paulo, em audiência pública organizada pela Comissão de Reforma do Judiciário, realizada em 5 de maio de 1999. Apesar de este magistrado concordar com a criação de um órgão de controle, incorporando juízes de primeiro grau e integrantes de outras instituições do sistema de justiça, ele ressalvava o que lhe pareciam ser desvantagens, caso a instituição tivesse braços nas unidades da Federação. Ponderou ele:

\begin{abstract}
"Com relação ao controle externo, há de fato uma preocupação de que órgãos regionais virem novas paróquias. Hoje há uma Corregedoria eficiente em relação à primeira instância - ou razoavelmente eficiência em relação à primeira instância -, mas não há Corregedoria em relação à segunda instância. Se temos essa preocupação em São Paulo, com uma população muito maior e, consequentemente, um contato menor de magistrados e parlamentares, tenho a preocupação de que isso se torne um novo órgão paroquial. Parece-me mais interessante a formação de um Conselho Nacional de Justiça, com a participação de técnicos, por se tratar de uma atividade técnica." ${ }^{, 83}$
\end{abstract}

Nas discussões de apreciação da proposta de reforma assinada pelo deputado Aloysio Nunes Ferreira, voltou a se manifestar, em junho de 1999, acrescentando outras justificativas às já expostas:

“(...) A questão do conselho de controle, (...) é, dentre todas as questões suscitadas pela reforma, a que mais me preocupa. Quantas Corregedorias

${ }^{82}$ Gomes, 1993, p. 39.

${ }^{83}$ Sadek, 2001, pp. 120-121. 
existem no Brasil incumbidas de fiscalizar a atuação do Poder Judiciário? São 26 estados, portanto, existem 26 corregedorias da Justiça Estadual. A Justiça Eleitoral está estabelecida em todos os estados da Federação e, portanto, temos mais 26 corregedorias dessa Justiça. Temos ainda corregedorias da Justiça Federal e, além delas, vasto Conselho da Justiça Federal com filiais em São Paulo e Rio de Janeiro. Lembrei-me agora do Distrito Federal, então, acrescente-se um para cada unidade. Isso tudo significa que devemos ter no Brasil mais de 100 corregedorias incumbidas de controlar os prazos judiciais e a normalidade e honestidade do andamento dos serviços cartoriais. E, a despeito da multidão de pessoas e multiplicidade de órgãos, aqui estamos na tentativa de criar mais um conselho nacional de controle do Poder Judiciário. E se não tivermos cuidado na elaboração desse conselho, todo o resultado do nosso trabalho se resumirá apenas numa coisa: talvez estejamos criando a $101^{\text {a }}$ Corregedoria da Justiça do Brasil. Antes, portanto, de escolhermos os membros do Conselho de Justiça, precisamos estabelecer sua competência. (...) Teremos que ter, então, órgão de controle do Judiciário que tenha natureza intervencionista. Um órgão de controle do Poder Judiciário que se incumba de moto-próprio da vigilância de todas as Comarcas e tribunais". ${ }^{84}$

Apenas com a Emenda Constitucional n. 45, de 2004, conseguiu-se criar o Conselho Nacional de Justiça como órgão de planejamento, coordenação e gestão administrativa, com função de fiscalização disciplinar do Poder Judiciário.

A criação do Conselho objetivou imprimir no Judiciário mudanças ordenadas e qualitativas, reavivando princípios constitucionais, estabelecendo novos critérios de administração judiciária, fiscalização das atividades desempenhadas pelos Tribunais e estimulando a responsabilidade social daquele Poder. ${ }^{85}$

É importante registrar que, embora condição insuficiente, a Emenda Constitucional é condição necessária ao início de uma profunda reforma estrutural do Judiciário. $^{86}$

\footnotetext{
${ }^{84}$ Sadek, 2001, pp. 164-165.

${ }^{85}$ Deocleciano, 2010, p. 12.

${ }^{86}$ Nalini, 2004, pp. 67-72.
} 
Deve-se registrar também que, embora louvável, o trabalho do legislador constituinte reformador que culminou com a criação do Conselho Nacional de Justiça não está isento de críticas.

Nesse sentido, destaca-se, a título de ilustração, o entendimento de Pedro Deocleciano, para quem alguns temas poderiam ter sido trabalhados de forma diferente. Com efeito, Pedro Deocleciano destaca, por exemplo, que o legislador da Emenda Constitucional n. 45/2004 preocupou-se mais com a manutenção da independência do Supremo Tribunal Federal - no sentido de não submetê-lo ao controle administrativo pelo Conselho Nacional de Justiça - do que com a do próprio Judiciário como um todo. ${ }^{87}$

Outro ponto objeto de crítica volta-se à composição do Conselho Nacional de Justiça, na medida em que não se estabeleceu assento para a Academia, que desempenha um papel fundamental na construção do pensamento das ciências jurídicas no país. Ainda nesta linha de raciocínio, não houve uma proposta, no momento da implementação da Emenda Constitucional n. 45, de concomitante reformulação da Lei Orgânica da Magistratura, o que diminui, em parte, o poder das determinações do Conselho. Outros avanços que poderiam ter sido feitos referem-se à questão da autonomia orçamentária e de formas mais democráticas de ascensão aos Tribunais. ${ }^{88}$

\section{5. Conselhos de Justiça no Direito Comparado}

\section{5.1. Panorama geral dos Conselhos de Justiça em outros ordenamentos jurídicos}

No mais amplo estudo sobre Conselhos de Justiça no âmbito da literatura jurídica brasileira, José Adércio Leite Sampaio ${ }^{89}$ relata que os sistemas jurídicos nacionais podem ser divididos entre aqueles que são dotados de Conselho Superior de Justiça e os

\footnotetext{
${ }^{87}$ Deocleciano, 2010, p. 124.

${ }^{88}$ Deocleciano, 2010, pp. 124-125.

${ }^{89}$ Sampaio, 2007, pp. 161-174.
} 
que não o possuem. Estes últimos podem ser subdivididos em sistemas com independência judiciária plena ${ }^{90}$ e sistemas com independência judiciária relativa ${ }^{91}$.

Já nos sistemas jurídicos em que há um órgão de governo e de administração de tribunais, existem dois grandes modelos. O primeiro modelo, de caráter anglo-americano, funda-se em um critério de independência e autonomia dos organismos judiciais, cujo governo e administração são exercidos pelos órgãos judiciais de maior hierarquia. O segundo modelo, de caráter europeu-continental, tem como elemento central a atribuição das competências de seleção, nomeação e fiscalização dos juízes a um órgão do Poder Executivo, normalmente o Ministério da Justiça. ${ }^{92}$

Para Mendes e Branco ${ }^{93}$, os Conselhos de Justiça de inspiração europeiacontinental foram instituídos e desenvolvidos com o primordial intuito de limitar a interferência do Poder Executivo no Poder Judiciário.

Entre os órgãos de administração da Justiça de inspiração europeiacontinental, destacam-se o Conselho Superior da Magistratura da Itália (Constituição de 1948), o Conselho Superior da Magistratura na França (Constituição de 1958), o Conselho Superior da Magistratura de Portugal (Constituição de 1976) e o Conselho Geral do Poder Judicial da Espanha (Constituição de 1978). ${ }^{94}$

Os Conselhos latino-americanos ${ }^{95}$, por sua vez, apresentam-se como modelos mistos, de influência tanto anglo-americana como europeia-continental ${ }^{96}$.

Outra classificação é proposta em estudo de Fernanda Flurh ${ }^{97}$, para quem, atualmente, existem dois grandes modelos de Conselhos de Justiça, sendo um com matriz franco-italiana, denominado de latino-europeu, e o outro chamado de nórdico-europeu.

\footnotetext{
90 Sampaio (2007, p. 162) ressalva que "não ter conselho não significa que falte instituição destinada a promover a independência do Judiciário, pelo menos no que se refere à forma de escolha dos juízes e, em especial, aqueles de instâncias inferiores. O Chile é um exemplo".

91 "Em outros sistemas constitucionais, a ausência de órgãos especializados na garantia da independência do Judiciário torna-o ligado aos outros poderes, ora por demandas orçamentárias, ora por deles depender para provimento de cargo de juízes, em muitos casos, para seu treinamento e formação”. São exemplos Grécia, Áustria, Luxemburgo, Austrália, Estados Unidos e Inglaterra. Sampaio, 2007, pp. 163-166.

${ }_{92}$ Mendes e Branco, 2012, p. 1070.

${ }^{93}$ Mendes e Branco, 2012, p. 1070.

${ }^{94}$ Estes quatro conselhos serão analisados posteriormente.

${ }^{95}$ Apresentam-se alguns exemplos, informando-se o ano de sua(s) Constituição(ões) e o(s) artigo(s) em que se encontram: Argentina (1853, 1994, art. 114), Bolívia, (1967, 1994, arts. 122 e 123), Colômbia (1991, arts. 254/257), Equador (1978, 1992, arts. 99/100 e 124/125), México (1917, 1994 e 1996, arts. 99/100), Paraguai (1992, arts. 162/264), Peru (1993, arts. 150/157) e Venezuela (1961, art. 217).

${ }^{96}$ Mendes e Branco, 2012, p. 1071.

${ }^{97}$ Flurh, 2012, pp. 58-59.
} 
Nos países que adotam o modelo latino-europeu ${ }^{98}$, os Conselhos enfocam questões relativas às formas de ingresso da magistratura e questões disciplinares Por outro lado, caracterizam o modelo nórdico-europeu a assunção de atribuições de autogoverno do Judiciário em sua quase plenitude e uma relativa independência do Executivo. Nesse sentido, destacam-se os Conselhos da Irlanda, da Suécia e da Dinamarca. ${ }^{99}$

Apesar das diferenças entre os modelos adotados, bem como as peculiaridades existentes em cada país, é possível encontrar um denominador comum, por meio do qual se pode caracterizar os Conselhos da Magistratura como "órgãos colegiados, de composição plural, integrados na estrutura do Poder Judicial, que têm como função exercer a administração dos órgãos jurisdicionais, assegurando autonomia e independência". 100

Apresentadas estas classificações, é interessante notar que a evolução histórica dos Conselhos de Justiça está diretamente relacionada com a busca pela conquista e pelo aumento da autonomia e da independência do Poder Judiciário.

Nesse sentido, Fernanda Flurh ${ }^{101}$ divide o período histórico da progressiva autonomia do judiciário em quatro fases. As duas primeiras - chamadas de (i) período revolucionário e (ii) período napoleônico - estão relacionadas com a afirmação da independência funcional. As duas últimas - (iii) período do surgimento dos conselhos judiciais e (iv) período da universalização dos conselhos judiciais - guardam maior relação com a independência orgânica do judiciário.

Na primeira fase - período revolucionário - sob inspiração dos ideais de Rousseau e de Montesquieu, o Judiciário era visto como uma função especializada limitada, ocupando o Legislativo o patamar de poder supremo e o Executivo o status de poder independente. ${ }^{102}$

\footnotetext{
${ }^{98}$ Merece registro a seguinte indicação de Fernanda Flurh (2011, pp. 63-64): "Importante destacar que o modelo latino-europeu dos conselhos de justiça exerce influência em outros países e continentes. Países como Hungria, Rússia, Ucrânia e outros Estados da Europa Oriental e da África, adotam o conselho de justiça com ênfase no processo de seleção dos juízes."

${ }_{99}$ Cf. Flurh, 2011, p. 241 e Sampaio, 2007, p. 178.

${ }^{100}$ Mendes e Branco, 2012, p. 1071.

${ }^{101}$ Flurh, 2011, p. 55.

102 Nesse sentido, Flurh (2011, p. 56), acrescenta ainda que a função do juiz era a de mero aplicador da lei ao caso concreto. Na verdade, "um agente público submetido a mandato e a eleições, com atribuições limitadas, sem poder de interpretação, pois, em caso de dúvidas quanto a aplicação das disposições legais, deveria submeter o problema à interpretação do legislativo para esclarecimento da vontade do legislador". Além disso, os juízes não podiam exercer o controle da atividade administrativa (...) Mas, isto não quer dizer que o juiz detinha papel irrelevante, pois, assim como o Parquet, já era detentor da garantia da inamovibilidade".
} 
Posteriormente, no período napoleônico, houve um importante aumento da autonomia do judiciário, com a equiparação dos juízes aos funcionários públicos, ainda que permanecessem submetidos hierarquicamente ao Ministro da Justiça. Neste período, ocorreu a transformação da Corte de Cassação em órgão da cúpula judiciária, objetivando uniformizar o ato interpretativo das leis e dar continuidade ao exercício da função disciplinar. ${ }^{103}$

José Adércio Leite Sampaio ${ }^{104}$ e Hamilton Schwartz ${ }^{105}$ também relacionam a criação dos conselhos judiciais à luta pela independência judicial na Europa, enfatizando, este último autor, que "a história dos conselhos judiciais está umbilicalmente ligada ao processo de independência do Poder Judiciário na Europa Continental e, mais especificamente, na França e na Itália”.

Além disso, é importante ponderar que os conselhos foram instalados na Europa também como resposta à necessidade de se criar uma agenda responsável e eficaz para as estruturas do Poder Judiciário, as quais cresciam demasiadamente sobretudo em decorrência das novas ondas de renovação do acesso à justiça. ${ }^{106}$

Neste ponto passa-se às fases do surgimento dos conselhos de justiça e sua posterior universalização. Nesse sentido, foi na Itália que ocorreu a criação do primeiro Conselho da Magistratura, o qual apresentava não apenas função disciplinar, mas também a função consultiva nas áreas de seleção, de transferência e de promoção dos juízes. ${ }^{107}$

Em seguida, constituiu-se, na França, o Conselho Superior da Magistratura, como órgão autônomo e destinado a garantir a independência do Judiciário e cuidar da seleção e da disciplina dos juízes. ${ }^{108}$

Depois disso iniciou-se uma fase de universalização do órgão, servindo os conselhos italiano e francês como modelos para o desenvolvimento de instituições semelhantes em outros países. É o que será visto a seguir, em uma breve análise dos

\footnotetext{
${ }^{103}$ Flurh, 2011, p. 56. Fernanda Flurh destaca ainda que, também neste período, no ano de 1817, ocorreu a profisssionalização dos juízes, por meio da edição de uma lei napolitana. Com isso, houve a instituição de mecanismo seletivo para ingresso na carreira e da garantia de estabilidade no cargo após três anos de exercício. O Ministro da Justiça e um tribunal superior passaram a compartilhar o exercício do poder disciplinar. Era uma tentativa de se reduzir as interferências na atividade judicial pelo Poder Executivo.

${ }^{104}$ Sampaio, 2007, p. 177.

${ }^{105}$ Schwartz, 2009, p. 268.

${ }^{106}$ Nesse sentido, Guerra, 2010, p. 88.

${ }^{107}$ Sampaio, 2007, p. 180 e Flurh, 2011, p. 58.

${ }^{108}$ Sampaio, 2007, pp. 183-184 e Flurh, 2011, p. 58.
} 
Conselhos de Justiça da Itália, da França, de Portugal e da Espanha e, de forma mais sintética, da Bélgica, da Turquia, de Andorra, da Irlanda, da Suécia e da Dinamarca.

\section{5.2. Conselho Italiano}

O Conselho de Justiça Italiano - Consiglio Superiore della Magistratura teve, como antecedentes históricos, importantes conquistas do Poder Judiciário ocorridas no século XIX, por meio da Lei Napolitana, de 1817, do Estatuto Albertino, de 1848, da Lei Siccardi, de 1851 e da Lei do Reino, de 1865, que estabeleceram, por exemplo, um mecanismo seletivo para ingresso na carreira, e as garantias de estabilidade, inamovibilidade e irredutibilidade dos salários dos juízes. ${ }^{109}$

O Conselho italiano, previsto nos artigos 104 e 105 da Constituição de $1948^{110}$, é composto pelos seguintes membros: (i) Presidente da República, que o preside, (ii) presidente da Corte de Cassação, (iii) Procurador-Geral junto à Corte de Cassação, (iv) dezesseis membros togados escolhidos pelo Judiciário dentre seus integrantes, e (v) dez membros escolhidos pelo Parlamento, dentre renomados juristas.

Dentre suas atribuições, destacam-se as seguintes: formulação de propostas ou pareceres ao Ministro da Justiça sobre modificação de circunscrições judiciárias e matérias relativas à administração, à organização e ao funcionamento dos serviços relativos à Justiça; exercício do poder disciplinar; condução do processo de seleção judicial, lotação, transferência e promoção de juízes. Predomina, assim, a função de controle da magistratura. ${ }^{111}$

\footnotetext{
109 Sampaio, 2007, p. 179. Para um estudo de literatura jurídica italiana acerca do Conselho Italiano, cf. Santosuosso, 1958.

${ }^{110}$ De acordo com a Constituição Italiana: “Art. 104. La magistratura costituisce un ordine autonomo e indipendente da ogni altro potere. Il Consiglio superiore della magistratura è presieduto dal Presidente della Repubblica. Ne fanno parte di diritto il primo presidente e il procuratore generale della Corte di cassazione. Gli altri componenti sono eletti per due terzi da tutti i magistrati ordinari tra gli appartenenti alle varie categorie, e per un terzo dal Parlamento in seduta comune tra professori ordinari di università in materie giuridiche ed avvocati dopo quindici anni di esercizio. Il Consiglio elegge un vice presidente fra $i$ componenti designati dal Parlamento. I membri elettivi del Consiglio durano in carica quattro anni e non sono immediatamente rieleggibili. Non possono, finché sono in carica, essere iscritti negli albi professionali, né far parte del Parlamento o di un Consiglio regionale. Art. 105. Spettano al Consiglio superiore della magistratura, secondo le norme dell'ordinamento giudiziario, le assunzioni, le assegnazioni ed $i$ trasferimenti, le promozioni e i provvedimenti disciplinari nei riguardi dei magistrati."

${ }^{111}$ Sampaio, 2007, p. 186.
} 
Interessante destacar a possibilidade de o Ministro da Justiça intervir nas reuniões do Conselho Superior da Magistratura. O Ministro da Justiça também pode, de forma concorrente, instaurar processo disciplinar contra magistrado e designar magistrados para o exercício de funções no Ministério da Justiça. ${ }^{12}$

\section{5.3. Conselho Francês}

A origem do Conselho da Magistratura da França - Conseil Supérieur de la Magistrature - remonta, da mesma forma que o Conselho Italiano, a acontecimentos históricos do século XIX, destacadamente o ano de 1883, quando as câmaras da Corte de Cassação reuniram-se com o fim de deliberar sobre matéria disciplinar dos magistrados. ${ }^{113}$

Com as Constituições de 1946 e de 1958, o Conselho ganhou autonomia, embora ainda fosse órgão auxiliar do presidente da República. Na década de 1990, com a Lei Constitucional de 1993 e a Lei Orgânica de 1994, modificou-se o tratamento do Conselho Francês, ampliando-se suas competências para os denominados magistrados do Parquet. $^{114}$

O Conselho Francês tem composição mista contando com doze representantes do Judiciário e do Ministério Público, que são por eles indicados, além de um membro do Conselho de Estado e de três membros escolhidos pelo chefe de Estado. É presidido pelo Presidente da República, que tem como seu vice, no Conselho, o Ministro da Justiça.

\footnotetext{
112 Sampaio, 2007, p. 186.

113 Sampaio, 2007, p. 183. Para um estudo de literatura jurídica francesa sobre o Conselho Francês, cf. Bodiguel, 1991, em especial pp. 246-252.

${ }^{114} \mathrm{O}$ atual tratamento constitucional do Conselho Francês está, sobretudo, nos artigos 64 e 65 , em que se destacam as seguintes passagens: "Art. 65. Le Conseil supérieur de la magistrature comprend une formation compétente à l'égard des magistrats du siège et une formation compétente à l'égard des magistrats du parquet. (...) La formation du Conseil supérieur de la magistrature compétente à l'égard des magistrats du parquet donne son avis sur les sanctions disciplinaires qui les concernent. Elle comprend alors, outre les membres visés au troisième alinéa, le magistrat du parquet appartenant à la formation compétente à l'égard des magistrats du siège. (...) Le Conseil supérieur de la magistrature se réunit en formation plénière pour répondre aux demandes d'avis formulées par le Président de la République au titre de l'article 64. Il se prononce, dans la même formation, sur les questions relatives à la déontologie des magistrats ainsi que sur toute question relative au fonctionnement de la justice dont le saisit le ministre de la justice. (...) La formation plénière comprend trois des cinq magistrats du siège mentionnés au deuxième alinéa, trois des cinq magistrats du parquet mentionnés au troisième alinéa, ainsi que le conseiller d'État, l'avocat et les six personnalités qualifiées mentionnés au deuxième alinéa. Elle est présidée par le premier président de la Cour de cassation, que peut suppléer le procureur général près cette cour. (...) Sauf en matière disciplinaire, le ministre de la justice peut participer aux séances des formations du Conseil supérieur de la magistrature."
} 
São atribuições do Conselho zelar pela independência do Poder Judiciário, adotar medidas disciplinares e realizar as promoções na carreira judicial. Nesse mister, emitem parecer e sugerem providências ao presidente da República, sobre a inspeção e o recolhimento de dados sobre a situação, organização e funcionamento da Corte de Cassação, das Cortes de Apelação, dos Tribunais e da Escola Nacional da Magistratura ${ }^{115}$.

Dentre suas competências, também ganha relevo a indicação ou recomendação de nomes ao presidente da República, para fins de ocupação dos postos do Judiciário. Nessa atividade, o Conselho examina o currículo dos candidatos e submete relatório ao presidente da República, para escolha dos magistrados judiciais da Corte de Cassação, dos primeiros presidentes das Cortes de Apelação e dos presidentes dos Tribunais de Grande Instância.

Cumpre destacar, por fim, que o Conselho de Justiça Francês é delineado como órgão puramente administrativo, e tal característica manifesta-se, por exemplo, na possibilidade de revisão de suas decisões pelo Conselho de Estado ${ }^{116}$.

\section{5.4. Conselho Português}

O Conselho de Justiça de Portugal - Conselho Superior da Magistratura - é órgão de gestão e disciplina da magistratura judicial, e tem por função salvaguardar as garantias institucionais de inamovibilidade e independência da Magistratura ${ }^{117}$. Sua composição e suas competências estão constitucionalmente definidas nos artigos 217 e $218^{118}$ da Constituição Portuguesa de 1976.

115 Flurh, 2011, pp. 59-60, acrescenta, ainda, o seguinte: "Muito embora se ressinta de meios próprios de
inspeção e de prerrogativas investigatórias, como poderes de condução coercitiva e de injunção, as condições
de infraestrutura e de segurança pessoal dos magistrados são informações relacionadas ao Judiciário também
prestadas pelo Conselho Francês, quando solicitadas pelo presidente da República ou pelo Ministro da
Justiça." Para um estudo de literatura jurídica portuguesa acerca do Conselho Português, cf. Sifuentes, 2000 .
116 Como bem salienta Sampaio, 2007, p. 185 , "o Conselho tem recebido diversas críticas que dão conta de
uma elevada ideologização do colegiado e, ao mesmo tempo, partidarização da magistratura, motivadas pelas
eleições de conselheiros e da injustificada diferença de tratamento entre magistrado judicial e du parquet,
possibilitando ao presidente inclusive nomear membros desta última categoria para assumir postos relevantes
no governo ao preço de uma combatida e ainda persistente vinculação entre os dois".
117 Flurh, 2011 , p. 62 .
118 Do conteúdo de tais artigos, destacam-se os seguintes trechos: "Artigo 217 . (Nomeação, colocação,
transferência e promoção de juízes) 1. A nomeação, a colocação, a transferência e a promoção dos juizes
dos tribunais judiciais e o exercício da acção disciplinar competem ao Conselho Superior da Magistratura,
nos termos da lei. 2. A nomeação, a colocação, a transferência e a promoção dos juizes dos tribunais
administrativos e fiscais, bem como o exercício da acção disciplinar, competem ao respectivo conselho 
Apesar de não possuir poder de iniciativa de lei, o Conselho Português, além de estudar e propor ao Ministro da Justiça providências legislativas com vista à eficiência e ao aperfeiçoamento das instituições judiciárias, pode emitir parecer sobre diplomas legais relativos à organização judiciária e ao estatuto dos magistrados judiciais. ${ }^{119}$

Outras importantes atribuições são a fixação do número e a composição das seções de tribunais e do Supremo Tribunal de Justiça, bem como a distribuição de processos nos tribunais com mais de um juízo. ${ }^{120}$

No que tange à sua competência disciplinar, destacam-se as atividades de determinação de sindicâncias e inquéritos aos serviços judiciais e de elaboração de plano anual de inspeções. ${ }^{121}$

Estão, ainda, entre as competências do Conselho Português ${ }^{122}$, o acompanhamento da primeira nomeação, lotação, transferência, promoção, exoneração e a apreciação do mérito profissional nos cursos e estágios de formação para ingresso na carreira judicial que ocorrem no Centro de Estudos Judiciários.

\section{5.5. Conselho Espanhol}

O Conselho de Justiça da Espanha - Consejo General del Poder Judicial está previsto normativamente no art. $122^{123}$ da Constituição Espanhola de 1978.

superior, nos termos da lei. (...) Artigo 218. (Conselho Superior da Magistratura) 1. O Conselho Superior da Magistratura é presidido pelo Presidente do Supremo Tribunal de Justiça e composto pelos seguintes vogais: a) Dois designados pelo Presidente da República; b) Sete eleitos pela Assembleia da República; c) Sete juizes eleitos pelos seus pares, de harmonia com o princípio da representação proporcional."

${ }^{119}$ Sampaio, 2007, pp. 188-189 e Flurh, 2011, p. 62.

${ }^{120}$ Sampaio, 2007, pp. 188-189 e Flurh, 2011, p. 62.

${ }^{121}$ Sampaio, 2007, pp. 188-189 e Flurh, 2011, p. 62.

122 Sampaio, 2007, p. 189.

${ }^{123}$ O conteúdo do art. 122 é o seguinte: "1. La Ley orgánica del poder judicial determinará la constitución, funcionamiento y gobierno de los Juzgados y Tribunales, así como el estatuto jurídico de los Jueces y Magistrados de carrera, que formarán un Cuerpo único, y del personal al servicio de la Administración de Justicia. 2. El Consejo General del Poder Judicial es el órgano de gobierno del mismo. La Ley orgánica establecerá su estatuto y el régimen de incompatibilidades de sus miembros y sus funciones, en particular en materia de nombramientos, ascensos, inspección y régimen disciplinario. 3. El Consejo General del Poder Judicial estará integrado por el Presidente del Tribunal Supremo, que lo presidirá, y por veinte miembros nombrados por el Rey por un período de cinco años. De éstos, doce entre Jueces y Magistrados de todas las categorías judiciales, en los términos que establezca la Ley Orgánica; cuatro a propuesta del Congreso de los Diputados y cuatro a propuesta del Senado, elegidos en ambos casos por mayoría de tres quintos de sus miembros, entre abogados y otros juristas, todos ellos de reconocida competencia y con más de quince años de ejercicio en su profesión." 
O Conselho Espanhol é composto por vinte membros nomeados pelo rei, por recomendação do Parlamento, e pelo presidente do Tribunal Supremo. Doze dos seus membros são oriundos do Judiciário, quatro são indicados pelo Congresso de Deputados e quatro são indicados pelo Senado, sendo, em ambos os casos, eleitos pela maioria de três quintos de seus membros entre juristas com mais de quinze anos de exercício profissional e de reconhecida competência.

Dentre suas atribuições, destaca-se o zelo pelo regime disciplinar, sobretudo pelo sistema de inspeções judiciais, objetivando o controle do funcionamento da administração da Justiça, atendendo especialmente às exigências impostas pelos deveres funcionais dos magistrados e pela pronta e eficaz prestação jurisdicional. Não pode, contudo, nesta atividade disciplinar, invadir o espaço de competência judicial na interpretação e na aplicação que os juízes fazem das leis. ${ }^{124}$

Também compete ao Conselho Espanhol cuidar da seleção, nomeação e promoção dos juízes. No caso das nomeações, sua atividade pode se dar de duas formas: quando do ingresso mediante realização de processo de seleção e de curso de preparação, por meio da Escola Judicial; e quando há nomeação mediante ordem, por meio de indicação, ao rei, de nomeação do presidente e dos magistrados do Tribunal Supremo e de dois magistrados do Tribunal Constitucional.

Para Flurh ${ }^{125}$, o Conselho Espanhol, em razão de seu status constitucional e da amplitude da lista de suas competências, tem sido objeto de críticas, no sentido de situálo fora do âmbito dos três poderes, sendo considerado como órgão constitucional autônomo encarregado do governo dos juízes e magistrados.

É oportuno observar que o Conselho Espanhol não sofre controle de legalidade dos seus atos pelo Tribunal Constitucional; deve, entretanto, apresentar relatório anual $^{126}$ a respeito do funcionamento e da atividade do Judiciário, ressaltando as questões dos recursos humanos, físicos e orçamentários.

\footnotetext{
${ }^{124}$ Sampaio, 2007, p. 187.

${ }^{125}$ Flurh, 2011, p. 61, citando Juan Aguilar, em sua obra La justicia y sus problemas en la Constitución (1996, p. 116).

${ }^{126}$ Granda (1993, pp. 156-157) relata que, nos termos do art. 109 da Lei Orgânica da magistratura espanhola, o CGPJ deverá elaborar, anualmente, relatório sobre "el estado, funcionamiento y actividades del proprio Consejo y de los Juzgados y Tribunales de Justicia". Tal relatório tem por finalidade lograr a inserção dos juízes na realidade social, eliminar práticas indevidamente sigilosas, fazer cumprir os deveres administrativos (assistência, horário, residência), exigir o rigoroso cumprimento das garantias do processo (prazo razoável, publicidade e oralidade) etc.
} 


\section{5.6. Outros Conselhos de Justiça: Bélgica, Turquia, Andorra, Irlanda, Suécia e Dinamarca}

Além dos conselhos de França, Itália, Portugal e Espanha, também são de inspiração latino-europeia os conselhos de Andorra, Bélgica e Turquia. Na atuação de tais conselhos, destaca-se a tutela das questões disciplinares e das formas de ingresso na Magistratura. ${ }^{127}$

O Conselho de Justiça de Andorra - Consell Superior de Justícia ${ }^{128}$ - é responsável pela seleção dos promotores e magistrados, pelo exercício do poder disciplinar e pela promoção das medidas necessárias para o cumprimento de deveres pela administração da Justiça. Seus membros, num total de apenas cinco, são indicados por diferentes autoridades de Estado, e possuem mandato de seis anos, não sendo permitida a recondução imediata. ${ }^{129}$

O Conselho de Justiça belga - Conseil Supérieur de la Justice ${ }^{130}$-, constituído em 1998, possui uma composição bastante paritária, com quarenta e quatro membros de nacionalidade belga, subdivididos em dois colégios, sendo um de língua holandesa e outro de língua francesa. Cada colégio conta com a participação de onze magistrados e onze não-magistrados. O mandato de todos é de quatro anos, podendo ser renovado uma única vez. Na Bélgica, com a criação do Conselho Superior de Justiça, as nomeações na Magistratura deixaram de sofrer interferências do Poder Executivo, como tradicionalmente ocorria. Tem, como funções primordiais, planejar o sistema de formação continuada e realizar exames de ingresso na carreira da magistratura e do Parquet. ${ }^{131}$

O Conselho Superior de Juízes e Promotores Públicos da Turquia - The High Council of Judges and Prosecutors ${ }^{132}$ - pode ser considerado frágil, dada a inexistência de um corpo burocrático e de orçamento próprios, dependendo sempre do

\footnotetext{
${ }^{127}$ Para um estudo analítico mais abrangente dos Conselhos de Justiça no âmbito da União Europeia, conferir o importante - embora não muito atualizado, pois foi finalizado em 2003 - estudo de Wim Voermans e Pim Albers, intitulado "Councils for the Judiciary in EU Countries", como parte dos trabalhos da Comissão Europeia para Eficiência do Judiciário. Há uma versão eletrônica disponível em: http://papers.ssrn.com/sol3/papers.cfm?abstract id=1271182.

${ }_{128}$ Para uma pesquisa mais detalhada sobre o Conselho de Andorra, cf. http://www.justicia.ad/es/coneix.

${ }^{129}$ Sampaio, 2007, p. 191 e Flurh, 2011, p. 63.

$130 \mathrm{O}$ histórico oficial do Conselho belga está apresentado, em língua francesa, em http://www.csj.be/fr/content/historique.

${ }_{131}$ Sampaio, 2007, pp. 189-190 e Flurh, 2011, p. 63.

${ }^{132} \mathrm{O}$ site oficial do The High Council of Judges and Prosecutors turco é http://www.hcjp.gov.tr/index.html.
} 
Executivo e sem a participação dos juízes e de promotores na designação de seus representantes. O Ministro da Justiça é o presidente do Conselho Turco, sendo este composto ainda pelo secretário-executivo do Ministério da Justiça e por três conselheiros indicados pela Corte Superior de Apelação e dois pelo Conselho de Estado. Dentre as atribuições deste Conselho, está a seleção, a transferência e a promoção de todos os juízes e promotores públicos, bem como a atividade disciplinar. ${ }^{133}$

Uma relativa independência do Executivo e a assunção de um grande número de atribuições de autogoverno do Judiciário caracterizam o modelo nórdicoeuropeu. Nesse sentido, destacam-se os Conselhos da Irlanda, da Suécia e da Dinamarca. ${ }^{134}$

O Conselho de Justiça Irlandês - Courts Service ${ }^{135}$-, constituído em 1998, possui atribuições de definição, fiscalização e controle dos gastos administrativos, elaboração de plano estratégico e de relatório anual, gerenciamento do banco de dados da jurisprudência, sugestão de mudanças legislativas, alocação pessoal de apoio aos juízes e aquisição de instalações de infraestrutura adequada ao bom funcionamento das Cortes. $\mathrm{O}$ Conselho Irlandês possui nove membros e é presidido por um representante do Chefe do Executivo. Dentre seus membros estão o procurador geral, dois advogados, membros dos escalões administrativos das cortes, um promotor público, um representante dos interesses da clientela do Judiciário, outro designado pelos sindicatos e um perito judicial. ${ }^{136}$

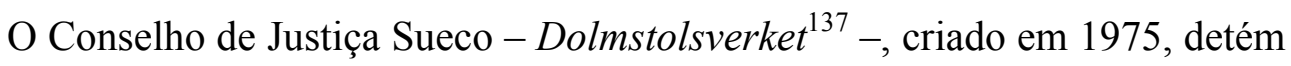
atribuições tais como recrutamento, treinamento e nomeação dos juízes, gerenciamento de recursos humanos, físicos e logísticos, formulação de projetos orçamentários para o Judiciário e distribuição entre os diversos ramos da Justiça, desenvolvimento e coordenação da política de custeio e investimento do Judiciário. A composição do Conselho da Suécia é mais simples do que o do Conselho Irlandês, possuindo, dentre seus membros, um diretor-geral, quatro juízes - dois presidentes da Corte Suprema e dois das Cortes de Apelação -, dois membros do Parlamento, um advogado e dois representantes sindicais. $^{138}$

\footnotetext{
${ }^{133}$ Sampaio, 2007, pp. 190-191 e Flurh, 2011, p. 63.

${ }^{134}$ Sampaio, 2007, p. 192.

135 Para uma pesquisa de dados acerca deste órgão judicial irlandês - Courts Service -, cf. http://www.courts.ie/courts.ie/library3.nsf/pagecurrent/39EE41AE3259894B80256DA90036F8BD?opendoc ument\&l=en.

${ }^{136}$ Sampaio, 2007, p. 193 e Flurh, p. 64.

137 A estrutura do The Swedish National Courts Administration está apresentada em maiores detalhes em: http://www.domstol.se/Funktioner/English/The-Swedish-National-Courts-Administration/.

${ }^{138}$ Sampaio, 2007, pp. 192-193 e Flurh, p. 64.
} 
Já o Conselho de Justiça Dinamarquês - Domstolsstyrelsen ${ }^{139}$-, constituído em 1999, tem composição e atribuições inspiradas no Conselho Sueco, sendo seus integrantes nomeados pelo Ministro da Justiça a cada quatro anos. Tal como ocorre no Conselho Sueco, as suas competências orçamentárias são destacadas tanto na fase de propositura por meio do Ministro da Justiça, quanto na fase de distribuição dos recursos e do respectivo acompanhamento da execução. ${ }^{140}$

\section{5. 7. Algumas importantes observações}

Apresentado este panorama geral dos Conselhos de Justiça, é necessário realizar, antes do estudo do Conselho Nacional de Justiça do Brasil, algumas importantes observações.

Pelo estudo que foi feito até este ponto, verificou-se que, apesar das variações nos vínculos institucionais, no número de membros, na forma e nos requisitos de sua designação, e nas atribuições e competências de cada um, os Conselhos ou órgãos de administração de tribunais e juízes foram estabelecidos, sobretudo, com o propósito primordial de garantir a independência do Poder Judiciário.

No Brasil, por outro lado, a instituição do Conselho Nacional de Justiça, que pode ser inserido, tal como os conselhos latino-americanos, num modelo de inspiração hibrida - com características tanto do modelo anglo-americano como do modelo europeucontinental - se deu, em especial, como resposta às deficiências de gestão administrativa do Poder Judiciário, na linha do que já foi abordado anteriormente.

Nesse sentido, Christiane Pedersoli ${ }^{141}$ relata que "destoam as finalidades de implantação dos conselhos da magistratura no contexto europeu e no brasileiro". Alexandre de Moraes também chama a atenção para as diferenças existentes entre a realidade político-constitucional europeia e a brasileira:

\footnotetext{
139 Para um histórico, em língua inglesa, das cortes judiciais na Dinamarca, inclusive sobre o Conselho Dinamarquês, cf. http://www.domstol.dk/om/otherlanguages/english/historicoutline/Pages/default.aspx.

${ }^{140}$ Sampaio, 2007, p. 193 e Flurh, 2011, pp. 64-65.

${ }^{141}$ Pedersoli, 2009, p. 65.
} 
"Os países europeus que adotaram fórmulas semelhantes de Conselhos Nacionais de Justiça são parlamentaristas ou semipresidencialistas, como no caso de Franca e Portugal, e o fizeram para ampliar a autonomia dos magistrados, diminuindo a ingerência política do Parlamento e do Primeiro-Ministro sobre o Judiciário." 142

Registre-se, ademais, o entendimento de Gustavo Guerra, para quem, no conjuntura existente antes da criação do Conselho Nacional de Justiça, mais do que medidas voltadas à independência judicial, eram necessárias "medidas de fiscalização" e "medidas de accountability", em contrapartida às "prerrogativas autonômicas" que possuíam apenas alguns poucos "mecanismos corporativos locais de responsabilização dos juízes desidiosos, incapazes ou corruptos", num quadro de "quase irresponsabilidade disciplinar dos integrantes dos tribunais". ${ }^{143}$

Dessa forma, o escopo do Conselho de Justiça brasileiro afastou-se da clássica marca de órgãos congêneres de outros países, tradicionalmente voltados à garantia da independência do Judiciário. ${ }^{144}$

Por tudo isso, a experiência dos Conselhos de Justiça em outros ordenamentos jurídicos não pode ser importada acriticamente para a realidade jurídica brasileira. No próprio Supremo Tribunal Federal, durante o julgamento da Ação Direta de Inconstitucionalidade n. 3367, sustentou-se este entendimento de que a experiência da Europa continental não se pode transpor sem traumas para o regime brasileiro:

"Na Europa, os conselhos da magistratura representaram um avanço significativo no sentido da independência do Judiciário, na medida em que nada the tomaram do poder de administrar-se, de que nunca antes dispuseram, mas, ao contrário, transferiram a colegiados onde a magistratura tem presença relevante, quando não majoritária, poderes de administração judicial e sobre os quadros da magistratura que historicamente eram reservados ao Executivo; a mesma instituição, contudo, traduziria retrocesso e violência constitucional, onde, como sucede no Brasil, a ideia da independência do Judiciário está

\footnotetext{
${ }^{142}$ Moraes, 2006, p. 1546.

${ }^{143}$ Guerra, 2010, p. 118.

${ }^{144}$ Sampaio, 2007, p. 273.
} 


extensamente imbricada com os predicados de autogoverno
crescentemente outorgados aos Tribunais." 145

Pondere-se, por fim, que apesar das deficiências que ainda podem ser observadas em cada sistema e em cada modelo, é inegável que “os Conselhos de Magistratura têm cumprido um relevante papel na solução dos complicados problemas relacionados à administração eficiente dos órgãos jurisdicionais." "146

Portanto, o conhecimento das condições que ensejaram e que permeiam a criação e a evolução destes órgãos, bem como o adequado entendimento de suas razões de ser, de suas estruturas e de seu funcionamento, tanto na experiência jurídica brasileira, como em outros países, é importante, como será visto, para o tratamento da competência disciplinar do Conselho Nacional de Justiça.

\footnotetext{
${ }^{145}$ Trecho do voto do Ex-Ministro Sepúlveda Pertence.

${ }^{146}$ Mendes e Branco, 2012, p. 1071.
} 


\section{CAPÍTULO II}

\section{ESTRUTURA E FUNCIONAMENTO DO \\ CONSELHO NACIONAL DE JUSTIÇA}

\section{II.1. Considerações Iniciais}

Seguindo orientação de Candido Rangel Dinamarco ${ }^{147}$, é importante e necessário, em todas as áreas científicas, que o conhecimento de uma função esteja sempre ligado ao conhecimento dos órgãos que a desempenham, sob pena de ser superficial ou desconectado da realidade.

Por este motivo, depois de delineado o contexto de criação do Conselho Nacional de Justiça, tarefa empreendida no capítulo anterior, o estudo volta-se à abordagem da estrutura e do funcionamento do Conselho, para, posteriormente, ser analisada a questão de sua competência disciplinar.

Para tanto, serão apresentados, neste capítulo, a estruturação do Conselho constitucionalmente definida, a estruturação e o funcionamento definidos no Regimento Interno do Conselho Nacional de Justiça e suas competências e mais relevantes aspectos institucionais.

Antes disso, porém, cabem algumas observações acerca da natureza jurídica do Conselho Nacional de Justiça.

É importante que se considere que o Conselho Nacional de Justiça brasileiro foi idealizado, durante muito tempo, antes de se chegar ao texto definitivo dado pelo legislador constituinte reformador de 2004, como órgão de controle externo. Contudo, nos termos materiais e formais como foi alçado ao patamar constitucional, o Conselho foi inserido, no artigo 92, I-A, da Constituição da República de 1988, pela Emenda

${ }^{147}$ Dinamarco, 2009, p. 352. 
Constitucional n. 45/2004, como órgão integrante do próprio Poder Judiciário nacional, motivo pelo qual não pode ser considerado externo. ${ }^{148}$

Nesse sentido, inclusive, o Supremo Tribunal Federal decidiu, no julgamento da Ação Direta de Inconstitucionalidade n. $3367^{149}$, invocando referido dispositivo constitucional, que o Conselho Nacional de Justiça é órgão interno de controle administrativo financeiro e disciplinar do Judiciário, ou seja, não é órgão jurisdicional, mas apenas um órgão do Judiciário, de natureza meramente administrativa.

Desse modo, a Corte Suprema afastou a tese da natureza do Conselho Nacional de Justiça como órgão de controle externo do Judiciário, rememorando que no sistema jurídico brasileiro existem os Tribunais de Contas, estes sim responsáveis por uma espécie de controle externo ao Poder Judiciário.

Portanto, com relação à sua natureza jurídica, pode-se afirmar que o Conselho Nacional de Justiça é um órgão do Poder Judiciário, de natureza constitucional, autônomo administrativa e funcionalmente, que desempenha funções políticoadministrativas relativas ao Poder que integra, com atuação em todo o território nacional. $^{150}$

Cumpre indicar o entendimento de Fernanda Flurh ${ }^{151}$ - apesar de não se concordar com ele, nos termos da definição apresentada acima - para quem o Conselho Nacional de Justiça, no âmbito das atribuições amplas que lhes foram conferidas pela Emenda Constitucional n. 45/2004, demonstra-se uma espécie sui generis de tribunal, com função jurisdicional atípica.

\footnotetext{
${ }^{148}$ Guerra, 2010, p. 85. Acerca da problemática de ser ou não órgão de controle externo, Gilberto Bercovici (2005, pp. 185-187), assinala que "toda a polêmica gerada sobre o 'controle externo' do Poder Judiciário e do Ministério Público não faz nenhum sentido", afirmando que "o controle destas instituições é perfeitamente adequado a um Estado Constitucional fundado na soberania popular e, no nosso caso, não foi criado nenhum controle externo real". Ademais, Bercovici, inspirado em Sieyès, diferencia poder constituinte de poder constituído, e afirma que o Poder Judiciário, por ser poder constituído, submete-se à Constituição e às leis. Por esta razão, não só pode, como deve ser controlado, para que não abuse de suas funções, ou para que não usurpe funções constitucionais de outros poderes constituídos ou, ainda, para que não tentem usurpar o próprio poder constituinte, colocando-se acima da própria Constituição e da soberania popular que a criou e a mantém.

${ }^{149}$ No julgamento da ADI 3367, o Supremo Tribunal Federal concluiu pela constitucionalidade da criação do Conselho Nacional de Justiça, arrematando que tal órgão "representa o símbolo da quebra do corporativismo que obscurece os procedimentos investigativos, debilita as medidas sancionatórias e desprestigia o Poder Judiciário". Tal julgamento será abordado no capítulo III deste trabalho.

${ }^{150}$ De acordo com o art. $1^{\circ}$ do Regimento Interno do Conselho Nacional de Justiça, o Conselho foi instalado no dia 14 de junho de 2005, como órgão do Poder Judiciário com atuação em todo o território nacional, com sede em Brasília-DF.

${ }^{151}$ Flurh, 2012, p. 80.
} 
Vale destacar também o registro feito por Alexandre de Moraes, no sentido de apontar que a criação do Conselho Nacional de Justiça e sua marcante atuação em relação às grandes questões da Magistratura "fizeram nascer um novo Direito Administrativo Judiciário". ${ }^{152}$

Este denominado "Direito Administrativo Judiciário" ou "direito administrativo da Justiça e das instituições judiciárias" tem por objeto a relação entre cada juiz e o Estado, ou entre o Estado e a Magistratura, e é integrado pelas normas que regem a organização judiciária - a qual tem natureza preponderantemente administrativa. ${ }^{153}$

Sob o prisma deste direito administrativo da Justiça, os juízes aparecem como "sujeitos de deveres, ônus, faculdades, prerrogativas e direitos, bem como destinatários de garantias e impedimentos". Além disso, "as normas sobre os temas de organização judiciária ou estão na própria Constituição Federal ou devem ser fiéis às linhas gerais integrantes da tutela constitucional da organização judiciária", sob pena de ilegitimidade. Tais normas "têm sua razão de ser no plano teórico da funcionalidade e eficiência do Poder Judiciário ou no plano político do federalismo brasileiro, da separação dos Poderes do Estado e da convivência internacional". ${ }^{154}$

Todos estes temas serão, ainda que algumas vezes de forma apenas tangencial, abordados a partir deste momento. Com efeito, ao se discorrer sobre a estrutura e o funcionamento do Conselho Nacional de Justiça, o que será feito neste capítulo, toca-se em questões ligadas à organização judiciária. Além disso, os temas do federalismo e da repartição de poderes foram enfrentados no julgamento da Ação Direta de Inconstitucionalidade n. 3367, como será visto no capítulo III. E, finalmente, a questão dos juízes como sujeitos de deveres e de direitos relaciona-se com as ideias de independência e responsabilização do Poder Judiciário, tema a ser tratado no capítulo IV.

Inicia-se, dessa forma, com a estrutura e o funcionamento do Conselho Nacional de Justiça.

\footnotetext{
${ }^{152}$ Moraes, 2010, p. 24.

${ }^{153}$ Dinamarco, 2009, p. 354.

${ }^{154}$ Dinamarco, 2009, pp. 354-355.
} 


\section{II.2 A estruturação definida constitucionalmente}

De acordo com o artigo 103-B, caput, da Constituição da República, inserido pela já referida Emenda Constitucional n. 45/2004, o Conselho é integrado por quinze membros, entre os quais nove pertencem aos quadros do Poder Judiciário.

Os quinze membros e a respectiva forma de nomeação são: (i) o Presidente do Supremo Tribunal Federal; (ii) um Ministro do Superior Tribunal de Justiça, indicado pelo respectivo tribunal; (iii) um Ministro do Tribunal Superior do Trabalho, indicado pelo respectivo tribunal; (iv) um desembargador de Tribunal de Justiça, indicado pelo Supremo Tribunal Federal; (v) um juiz estadual, indicado pelo Supremo Tribunal Federal; (vi) um juiz de Tribunal Regional Federal, indicado pelo Superior Tribunal de Justiça; (vii) um juiz federal, indicado pelo Superior Tribunal de Justiça; (viii) um juiz de Tribunal Regional do Trabalho, indicado pelo Tribunal Superior do Trabalho; (ix) um juiz do trabalho, indicado pelo Tribunal Superior do Trabalho; (x) um membro do Ministério Público da União, indicado pelo Procurador-Geral da República; (xi) um membro do Ministério Público estadual, escolhido pelo Procurador-Geral da República dentre os nomes indicados pelo órgão competente de cada instituição estadual; (xii e xiii) dois advogados, indicados pelo Conselho Federal da Ordem dos Advogados do Brasil; (xiv e xv) dois cidadãos ${ }^{155}$, de notável saber jurídico e reputação ilibada, indicados um pela Câmara dos Deputados e outro pelo Senado Federal. ${ }^{156}$

Com exceção do Presidente do Supremo Tribunal Federal, os demais membros do Conselho são nomeados pelo Presidente da República, depois de aprovada a escolha pela maioria absoluta do Senado Federal. ${ }^{157}$ Na ausência de indicação de membros para a composição do Conselho pelos respectivos órgãos, a escolha cabe ao Supremo Tribunal Federal. ${ }^{158}$ Os Conselheiros são nomeados para um mandato de dois anos, e admite-se uma recondução.

\footnotetext{
155 No julgamento do MS 25.393-AgR/DF, de relatoria do Ministro Marco Aurélio, o Supremo Tribunal Federal decidiu que inexiste direito subjetivo à nomeação para o Conselho Nacional de Justiça, considerada vaga destinada à escolha do Senado Federal.

${ }^{156}$ Constituição da República, art. 103-B, caput.

157 Constituição da República, art. 103-B, parágrafos $1^{\circ}$ e $2^{\circ}$. A Emenda Constitucional n. 61, de 2009, suprimiu a exigência de sabatina do Presidente do Supremo Tribunal Federal pelo Senado Federal.

${ }^{158}$ Constituição da República, art. 103-B, parágrafo $3^{\circ}$.
} 
É interessante destacar que, com a Emenda Constitucional n. 61, de 11 de novembro de 2009, modificou-se uma exigência que se mostrava pouco razoável. Até a sua edição, não se podiam nomear para o Conselho indivíduos com mais de 66 anos de idade. Com esta reforma, também se extinguiu a exigência de idade mínima de 35 anos para o cargo de conselheiro. ${ }^{159}$

O Conselho é presidido pelo Presidente do Supremo Tribunal Federal e, nas suas ausências e impedimentos, assumirá a posição de Presidente do Conselho o VicePresidente do Supremo Tribunal Federal. ${ }^{160}$

A Emenda Constitucional n. 61, de 2009, também suprimiu do texto constitucional disposição segundo a qual o Presidente do Conselho votaria apenas em caso de empate, estando excluído da distribuição de processos no âmbito do Conselho. Desse modo, esta matéria fica aberta à disciplina regimental. ${ }^{161}$

De destacado interesse para o tema da competência disciplinar do Conselho é a determinação constitucional no sentido de que “a função de Ministro-Corregedor" é

\footnotetext{
${ }^{159}$ Constituição da República, art. 103-B, caput.

160 Há uma interessante decisão acerca da necessidade ou não do efetivo exercício da presidência do Conselho Nacional de Justiça pelo Presidente do Supremo Tribunal Federal, colacionada no Informativo Mensal de Jurisprudência do STF n.20, Junho de 2012 - "CNJ: PAD e punição de magistrado". No MS 28.816160 (Rel. Ministr Joaquim Barbosa), o Plenário do STF denegou mandado de segurança impetrado por juíza de direito contra decisão proferida pelo CNJ, que instaurara Processo Administrativo Disciplinar contra ela, a despeito de a Corte local, à qual vinculada, haver determinado a não instauração de procedimento. A impetrante sustentava nulidade do ato impugnado, visto que: a) o CNJ somente teria competência para rever decisões proferidas ao término de PAD; b) não haveria demonstração de que o tribunal de justiça teria agido em contrariedade às provas contidas em sindicância levada a termo pela corregedoria estadual; c) os fundamentos defensivos apresentados perante o CNJ não teriam sido apreciados; e d) a sessão em que proferido o ato fora presidida por integrante do STJ, em suposta afronta ao art. 103-B da CF. Preliminarmente, por maioria, decidiu-se não ser necessário que as sessões do CNJ fossem presididas por Ministro do STF. Destacou-se que, embora o art. 103-B, $\S 1^{\circ}$, da $\mathrm{CF}$, prescrevesse que o "Conselho será presidido pelo Ministro do Supremo Tribunal Federal", o inciso I do mesmo dispositivo reservaria apenas um assento do CNJ para membro do Supremo. Assim, a previsão constitucional de apenas um Ministro do STF, considerado o caráter ordinário e previsível de eventuais afastamentos temporários em qualquer órgão colegiado, infirmaria a interpretação de que, em toda e qualquer oportunidade, as sessões do CNJ devessem necessariamente ser presididas por Ministro desta Corte. Ademais, como o Vice-Presidente do Supremo, que em tese poderia substituir o Presidente em eventual ausência, teria outras atribuições, não seria razoável interpretar a Constituição de modo a condicionar a atuação do CNJ à criação de cronograma voltado a garantir que mais um Ministro da Corte ficasse de prontidão, em prejuízo de suas obrigações constitucionais principais. Afirmou-se que posição contrária levaria à paralisação do colegiado do CNJ. O Ministr Luiz Fux consignou decisão da Corte na qual se deliberara não haver nulidade quando sessão do CNJ fosse presidida pelo Corregedor-Geral de Justiça, desde que a assentada tivesse sido realizada antes da vigência da EC 61/2009, ou seja, anteriormente a 12.11.2009, como no caso dos presentes autos. Vencidos os Ministros Ricardo Lewandowski e Marco Aurélio, que acolhiam a preliminar. O Ministr Marco Aurélio observava que a EC 61/2009 teria apenas explicitado o que já contido na ordem jurídica, ou seja, a substituição do Presidente do CNJ pelo Vice-Presidente do STF. O Ministr Ricardo Lewandowski ressalvava que, por motivos de segurança jurídica, dever-se-ia preservar as decisões tomadas no passado". Sem destaque no original.

${ }^{161}$ Mendes e Branco, 2012, p. 1073.
} 
exercida pelo Ministro do Superior Tribunal de Justiça, o qual fica excluído da distribuição de processos no Tribunal. ${ }^{162}$

Compete ao Corregedor Nacional de Justiça, além das atribuições que lhe forem conferidas pelo Estatuto da Magistratura receber as reclamações e denúncias, de qualquer interessado, relativas aos magistrados e aos serviços judiciários; exercer funções executivas do Conselho, de inspeção e de correição geral; e requisitar e designar magistrados, delegando-lhes atribuições, e requisitar servidores de juízos ou tribunais, inclusive nos Estados, Distrito Federal e Territórios. ${ }^{163}$

Ainda quanto à estrutura do Conselho, há previsão constitucional expressa $^{164}$ que impõe a criação, pela União, de ouvidorias de justiça, para recebimento de reclamações e denúncias feitas por quaisquer interessados contra membros e órgãos do Poder Judiciário, remetendo-as diretamente ao Conselho.

A previsão da existência e funcionamento de órgãos de comunicação de denúncias, reclamações e sugestões visa a preencher uma grande lacuna de integração existente entre os órgãos jurisdicionais e a população, buscando ampliar o acesso à justiça e apurar os erros e falhas que mais afetam a sociedade.

Em razão da relevante função que desempenham, os Conselheiros serão processados e julgados, em caso de cometimento de crimes de responsabilidade, pelo Senado Federal, da mesma forma que os Ministros do Supremo Tribunal Federal, os membros do Conselho Nacional do Ministério Público, o Procurador-Geral da República e o Advogado-Geral da União ${ }^{165}$.

Apresentada a conformação estrutural do Conselho Nacional de Justiça dada pela Constituição da República de 1988, com as alterações levadas a efeito pelas Emendas Constitucionais n. 45, de 2004, e n. 61, de 2009, passa-se à abordagem da estruturação e do funcionamento definidos regimentalmente.

\footnotetext{
${ }^{162}$ Constituição da República, art. 103-B, parágrafo $5^{\circ}$.

${ }^{163}$ Constituição da República, art. 103-B, parágrafo $5^{\circ}$.

${ }^{164}$ Constituição da República, art. 103-B, parágrafo $7^{\circ}$.

${ }^{165}$ Constituição da República, art. 52, II.
} 


\section{II.3 A estruturação e o funcionamento definidos regimentalmente}

Nos termos do Regimento Interno do Conselho Nacional de Justiça (RICNJ), a estrutura interna do Conselho é composta por nove órgãos: (i) o Plenário; (ii) a Presidência; (iii) a Corregedoria Nacional de Justiça; (iv) os Conselheiros; (v) as Comissões; (vi) a Secretaria-Geral; (vii) o Departamento de Pesquisas Judiciárias - DPJ; (viii) o Departamento de Monitoramento e Fiscalização do Sistema Carcerário e do Sistema de Execução de Medidas Socioeducativas - DMF; e (ix) a Ouvidoria.

O órgão máximo de julgamento é constituído pelo Plenário, que se reúne com o mínimo de dez conselheiros. A este órgão compete o controle da atuação administrativa e financeira do Poder Judiciário e do cumprimento dos deveres funcionais dos magistrados ${ }^{166}$.

Dentre as competências do Plenário do Conselho, algumas merecem destaque, como, por exemplo: (i) a avocação, se entender conveniente e necessário, de processos disciplinares em curso; (ii) a proposição de realização, pelo Corregedor Nacional de Justiça, de correições, inspeções e sindicâncias em varas, Tribunais, serventias judiciais e serviços notariais e de registro; (iii) o julgamento dos processos disciplinares regularmente instaurados contra magistrados, podendo determinar a remoção, a disponibilidade ou a aposentadoria com subsídios ou proventos proporcionais ao tempo de serviço e aplicar outras sanções administrativas previstas em lei complementar ou no Regimento Interno do Conselho, assegurada a ampla defesa; e (iv) a revisão, de ofício, ou mediante provocação, os processos disciplinares contra juízes de primeiro grau e membros de Tribunais julgados há menos de um ano ${ }^{167}$. Note-se que se buscou destacar atribuições que apresentam direta relação com o exercício da competência disciplinar do Conselho.

Por fim, interessa mencionar, em relação ao Plenário, que não cabe recurso, de caráter administrativo, em face dos atos e das decisões proferidas por este órgão do Conselho.

$\mathrm{O}$ artigo $5^{\circ}$ do RICNJ reproduz norma constitucional relativa à Presidência do Conselho, no sentido de que essa será exercida pelo Presidente do Supremo Tribunal Federal e, em suas ausências e impedimentos, pelo Vice-Presidente daquele Tribunal. É

\footnotetext{
${ }^{166}$ RICNJ, art. $4^{\circ}$ caput.

${ }^{167}$ RICNJ, art. $4^{\mathrm{o}}$, IV, V, VI e VIII.
} 
oportuno frisar que a Emenda Regimental n. 1, de 2010, procurou adequar o texto regimental às alterações constitucionais promovidas pela Emenda Constitucional n. 61, de 2009.

Também faz parte da estrutura do Conselho a Corregedoria Nacional de Justiça, dirigida pelo Corregedor Nacional de Justiça, que dispõe, para auxiliá-lo, de Secretaria e Assessoria próprias, bem como de magistrados requisitados.

O Corregedor Nacional de Justiça tem ampla competência, destacadamente de caráter disciplinar: receber as reclamações e denúncias de qualquer interessado relativas aos magistrados e Tribunais e aos serviços judiciários auxiliares, serventias, órgãos prestadores de serviços notariais e de registro ${ }^{168}$; instaurar sindicância ou propor ao Plenário, desde logo, a instauração de processo administrativo disciplinar, quando houver indício suficiente de infração; promover ou determinar a realização de sindicâncias, inspeções e correições, quando houver fatos graves ou relevantes que as justifiquem, desde logo determinando as medidas que se mostrem necessárias, urgentes ou adequadas, ou propondo ao Plenário a adoção das medidas que lhe pareçam suficientes a suprir as necessidades ou deficiências constatadas. ${ }^{169}$

Um importante instrumento de que se vale o Corregedor Nacional de Justiça no exercício de suas atividades é a requisição a autoridades fiscais, monetárias e outras autoridades competentes de informações, exames, perícias ou documentos, sigilosos ou não, que se apresentem imprescindíveis ao esclarecimento de processos ou procedimentos submetidos à sua apreciação, dando conhecimento ao Plenário. ${ }^{170}$

Ao observar as funções constitucionais outorgadas à Corregedoria Nacional de Justiça, órgão do Conselho, verifica-se que há duas atividades específicas: “corregência, função executiva do Conselho, fiscalizando e viabilizando para os juízes e tribunais o cumprimento da política traçada pelo Conselho por meio das metas" - inciso II do $\S 5^{\circ}$ do art.103-B; e "função disciplinar, recebendo reclamações e denúncias contra

\footnotetext{
${ }^{168}$ Nesse mister, pode determinar o arquivamento sumário das anônimas, das prescritas e daquelas que se apresentem manifestamente improcedentes ou despidas de elementos mínimos para a sua compreensão, de tudo dando ciência ao reclamante; pode também determinar o processamento das reclamações que atendam aos requisitos de admissibilidade, arquivando-as quando o fato não constituir infração disciplinar.

${ }^{169}$ RICNJ, art. $8^{\circ}$.

${ }^{170}$ Guerra (2010, p. 127) pondera que "a Corregedoria Nacional de Justiça pode realizar inspeções para a apuração de fatos relacionados com deficiências graves dos serviços judiciais e auxiliares, das serventias e dos órgãos prestadores de serviços notariais e registrais. Esses expedientes contam com a participação ativa do órgão sob inspeção, franqueando, ainda, aos seus servidores e aos jurisdicionados, em geral, discutirem, por meio de audiências públicas, providências que restituam boas práticas aos serviços avaliados ou aprimorem as existentes, no sentido de uma uniformização dos procedimentos".
} 
magistrados e servidores, investigando e propondo aplicação de sanções administrativodisciplinares". 171

Uma benfazeja medida da Corregedoria Nacional de Justiça foi o estabelecimento de metas de nivelamento das corregedorias de todo o país. Dentre estas metas, destacam-se as seguintes: apresentar, no prazo de 120 dias, de plano de gestão para as corregedorias; publicar $100 \%$ das ações correcionais (preservando o sigilo); relatar, em até 180 dias, $80 \%$ dos procedimentos administrativos disciplinares; realizar, anualmente, correição em pelo menos 30\% das unidades jurisdicionais, ainda que por amostragem; fiscalizar $100 \%$ das metas do Poder Judiciário Nacional. ${ }^{172}$

Em relação aos Conselheiros, algumas considerações devem ser feitas, em acréscimo ao que já foi apresentado no item anterior. Os Conselheiros oriundos da Magistratura e do Ministério Público poderão se afastar de suas atividades funcionais perante esses órgãos. Os Conselheiros perderão os seus mandatos em virtude de sentença judicial transitada em julgado, declaração, pelo Plenário, de perda do mandato por invalidez e de condenação, pelo Senado Federal, em crime de responsabilidade. ${ }^{173}$

Em razão da importância de sua função e em respeito ao próprio exercício da atividade correcional e fiscalizadora que lhes compete, os Conselheiros guardam as mesmas garantias, prerrogativas, impedimentos e suspeições dos membros da Magistratura ${ }^{174}$, ainda que a função seja exercida temporariamente - no prazo de dois anos prorrogável por igual período, em caso de recondução. ${ }^{175}$

Além disso, os membros do Conselho não podem exercer atividades incompatíveis com a função de Conselheiro. Sendo assim, não podem concorrer à vaga do quinto constitucional os Conselheiros provenientes do Ministério Público ou Advocacia. Os membros originariamente pertencentes ao órgão ministerial e os magistrados indicados para o Conselho não podem ser promovidos por critério de merecimento na respectiva carreira. Também fica vedada a indicação de conselheiro para integrar tribunal superior

\footnotetext{
${ }^{171}$ Calmon, 2012, sem paginação.

172 Informações oficiais extraídas do site do Conselho Nacional de Justiça. Cf., especificamente, http://www.cnj.jus.br/noticias/cnj/17005:corregedorias-aprovam-metas-para-2012.

${ }_{173}^{17}$ RICNJ, arts. 16 e 17.

${ }^{174}$ Sampaio, 2007, p. 267. Nesse sentido também é o entendimento de Mendes e Branco (2012, p. 1076): “o próprio Congresso Nacional havia aprovado proposta de emenda que impõe aos membros do Conselho as mesmas restrições e impedimentos constitucionais impostos aos juízes, o que estaria a sinalizar a plena integração do órgão na estrutura do Poder Judiciário".

${ }^{175}$ RICNJ, arts. 11 a 15.
} 
durante o mandato no Conselho e até dois anos após o término, tampouco podendo advogar perante o Conselho nos três anos subsequentes à saída desse órgão. ${ }^{176}$

As Comissões, que podem ser permanentes ou temporárias, são criadas pelo Plenário e compõem-se por, no mínimo, três Conselheiros. Constituem-se para o estudo de temas e o desenvolvimento de atividades específicas do interesse respectivo ou relacionadas com suas competências. ${ }^{177}$

A Secretaria-Geral é responsável por assegurar a assessoria e o apoio técnico e administrativo necessários à preparação e à execução de sua gestão administrativa, das atividades do Plenário, da Presidência do CNJ, da Corregedoria Nacional de Justiça, dos Conselheiros e das Comissões. ${ }^{178}$

Existem ainda, na composição do Conselho, dois importantes departamentos. O Departamento de Pesquisas Judiciárias, normatizado pela Lei n. 11.364/2006, tem por objetivo desenvolver pesquisas destinadas ao conhecimento da função jurisdicional brasileira, realizar análise e diagnóstico dos problemas estruturais e conjunturais dos diversos segmentos do Poder Judiciário e fornecer subsídios técnicos para a formulação de políticas judiciárias ${ }^{179}$. Já o Departamento de Monitoramento e Fiscalização do Sistema Carcerário e do Sistema de Execução de Medidas Socioeducativas foi criado pela Lei n. 12.106/2009. Trata-se de órgão com a elevada função de acompanhamento e fiscalização do sistema carcerário e de execução de medidas socioeducativas no âmbito do Poder Judiciário. ${ }^{180}$

Por fim, existe a Ouvidoria, que é coordenada por um Conselheiro tem atribuições definidas em ato do Plenário ${ }^{181}$. Trata-se da unidade responsável pelo Serviço de Atendimento ao Cidadão, conforme estabelece a Lei 12.527 de 2011 - conhecida como lei de acesso à informação. Segundo o inciso I do artigo $9^{\circ}$ da Lei, o serviço de

\footnotetext{
${ }^{176}$ Sampaio, 2007, p. 268. Nacional de Justiça (www.cnj.jus.br). pelo Presidente do CNJ.

${ }^{179}$ RICNJ, arts. 36 a 40 e Lei $11.364 / 06$, art. $5^{\circ}$, parágrafo $1^{\circ}$.

${ }^{180}$ RICNJ, arts. 40-A e 40-B.

${ }^{181}$ RICNJ, art. 41, parágrafo único.
}

177 RICNJ, art. 28. Existem, atualmente, as seguintes composições: Comissão de Acesso à Justiça e à Cidadania; Comissão de Eficiência Operacional e Gestão de Pessoas; Comissão de Gestão Estratégica, Estatística e Orçamento; Comissão de Regimento Interno; Comissão de Tecnologia da Informação e Infraestrutura; Comissão Permanente de Articulação Federativa e Parlamentar e Comissão Permanente de Jurisprudência. Para informações institucionais acerca de cada uma delas, bastar acessar o site do Conselho

178 RICNJ, arts. 32 a 35. Acresça-se que, nos processos administrativos submetidos ao CNJ, os atos ordinatórios, de administração ou de mero expediente serão executados pela Secretaria-Geral; as comunicações, determinações ou ordens de execução concessivas ou restritivas de direito serão subscritas 
informações ao cidadão nos órgãos e entidades do Poder Público deve atender e orientar o público, informar sobre a tramitação de documentos e protocolar requerimentos de acesso à informação. O Serviço de Atendimento ao Cidadão do Conselho foi instituído na gestão sob a Presidência do Ministro Ayres Britto. De acordo o disposto no art. $2^{\circ}$ e $4^{\circ}$, III, da Resolução n. 103/2010, a Ouvidoria tem por função orientar, transmitir informações e colaborar no aprimoramento das atividades desenvolvidas pelo Conselho, bem como promover a interação com os demais órgãos do Poder Judiciário para o atendimento às demandas recebidas e aperfeiçoamento dos serviços prestados.

As sessões serão públicas, exceto nas hipóteses de sigilo previstas na Constituição Federal e de proteção do direito à intimidade. As sessões do Plenário poderão ser ordinárias ${ }^{182}$, extraordinárias ${ }^{183}$ ou de planejamento. ${ }^{184}$

As decisões do Plenário do Conselho e das Comissões serão tomadas pelo voto da maioria simples dos Conselheiros presentes, observado o quorum regimental, exceto nos casos em que haja exigência de quorum qualificado. ${ }^{185}$

Nos julgamentos, será assegurado direito à sustentação oral ao interessado ou ao seu advogado e, se for o caso, ao Presidente do Tribunal, pelo prazo de dez minutos. Pode haver a manifestação de presidente de associação de juízes presentes à sessão. Durante os debates, cada Conselheiro poderá falar tantas vezes sobre o assunto em discussão quantas forem necessárias ao esclarecimento da causa ou, em regime de votação, para explicar a modificação do voto, desde que autorizado pelo Presidente. O Plenário poderá converter o julgamento em diligência, quando necessária à decisão da causa. ${ }^{186}$

Finalmente, muito importante é a norma contida no art. 138 do RICNJ, a qual permite ${ }^{187}$ ao Conselho, até a entrada em vigor o Estatuto da Magistratura, a edição de resolução com o objetivo de disciplinar seu funcionamento, dispor sobre a sua estrutura, direitos e deveres de seus Conselheiros, bem como sobre cargos e funções indispensáveis ao seu regular funcionamento.

\footnotetext{
${ }^{182}$ As sessões ordinárias serão realizadas quinzenalmente, em dias úteis, mediante prévia comunicação aos Conselheiros do calendário de planejamento instituído ao início de cada semestre.

${ }^{183}$ As sessões extraordinárias serão convocadas pelo Presidente, fora do calendário semestral estabelecido, com pelo menos dois dias úteis de antecedência. O Presidente convocará sessão extraordinária, que se realizará em até quinze (15) dias, quando requerida, por escrito, por um terço dos Conselheiros, devendo o requerimento indicar o tema objeto de análise e deliberação.

${ }^{184}$ RICNJ, arts. 116 a 118.

${ }^{185}$ RICNJ, art. 121

${ }^{186}$ RICNJ, arts. 122-134.

${ }^{187}$ Com fundamento no art. $5^{\circ}, \S 2^{\circ}$, da EC n. 45/2004.
} 


\section{II.4. Competências, atribuições e aspectos institucionais relevantes}

O Conselho Nacional de Justiça foi instituído com o objetivo de ser um instrumento efetivo de desenvolvimento do Poder Judiciário, e tem por missão institucional contribuir para que a prestação jurisdicional seja realizada com moralidade, eficiência e efetividade, em benefício da sociedade. ${ }^{188}$

Na visão da Ministra Eliana Calmon, Ex-Corregedora Nacional de Justiça, o Conselho tem, como objetivos-macro, a responsabilização, a democratização, o planejamento e a publicidade. ${ }^{189}$

Como já foi apontado no primeiro capítulo, José Adércio Leite Sampaio evidencia que, no Brasil, os objetivos da criação do Conselho estão menos voltados à racionalização da administração da Justiça e ao zelo pela independência no Judiciário, e sim mais orientados ao estabelecimento de accountability, fiscalização e controle para modernização do funcionamento interno do Poder, à racionalização do uso dos recursos humanos e financeiros, e "ao combate ao nepotismo, à corrupção, à má-gestão". ${ }^{190}$

Nesse contexto, sua atuação tem por diretrizes: (i) planejamento estratégico e proposição de políticas judiciárias; (ii) modernização tecnológica do Judiciário; (iii) ampliação do acesso à justiça, pacificação e responsabilidade social; e (iv) garantia de efetivo respeito às liberdades públicas e execuções penais.

Conferindo transparência à sua atuação, o Conselho Nacional de Justiça tem publicado, anualmente, relatórios bastante completos e elucidativos, informando suas ações, dividindo-as por temas e objetivos estratégicos, da seguinte forma: (i) ações de fiscalização e correição, objetivando garantir a conformidade aos princípios constitucionais na atuação administrativa e financeira do Poder Judiciário; (ii) ações de alinhamento e integração, com os objetivos de garantir o alinhamento estratégico em todas as unidades do Judiciário, promover a modernização tecnológica do Poder Judiciário e fomentar a integração e a troca de experiência entre Tribunais; (iii) ações institucionais, visando a fortalecer e harmonizar as relações entre os Poderes, setores e instituições e aprimorar a comunicação com públicos externos; (iv) ações de eficiência operacional, para garantir a

\footnotetext{
${ }^{188}$ Este "objetivo" e esta "missão institucional" são desta forma apresentados no próprio site institucional oficial do Conselho Nacional de Justiça. Cf., nesse sentido, www.cnj.jus.br.

${ }^{189}$ Calmon, 2012, sem paginação.

${ }^{190}$ Sampaio, 2007, p. 272.
} 
agilidade nos trâmites judiciais e administrativos; (v) ações em gestão de pessoas, almejando desenvolver conhecimentos, habilidades e atitudes dos Conselheiros, magistrados e servidores; (vi) ações de infraestrutura e tecnologia ${ }^{191}$, com o intuito de garantir a infraestrutura apropriada às suas atividades; (vii) ações orçamentárias, para assegurar recursos orçamentários necessários para execução da estratégia; (viii) ações junto aos Tribunais Superiores, contendo, em especial, o relato dos principais projetos alinhados aos temas estratégicos do Poder Judiciário. ${ }^{192}$

Possibilitam a atuação do Conselho, de acordo com o direcionamento acima proposto, as competências que lhe são constitucional e infraconstitucionalmente atribuídas.

Nos termos do parágrafo $4^{\circ}$ do art. 103-B da Constituição da República:

"compete ao Conselho o controle da atuação administrativa e financeira do Poder Judiciário e do cumprimento dos deveres funcionais dos juízes, cabendo-lhe, além de outras atribuições que lhe forem conferidas pelo Estatuto da Magistratura: I - zelar pela autonomia do Poder Judiciário e pelo cumprimento do Estatuto da Magistratura, podendo expedir atos regulamentares, no âmbito de sua competência, ou recomendar providências; II - zelar pela observância do art. 37 e apreciar, de ofício ou mediante provocação, a legalidade dos atos administrativos praticados por membros ou órgãos do Poder Judiciário, podendo desconstituí-los, revê-los ou fixar prazo para que se adotem as providências necessárias ao exato cumprimento da lei, sem prejuízo da competência do Tribunal de Contas da União; III - receber e conhecer das reclamações contra membros ou órgãos do Poder Judiciário, inclusive contra seus serviços auxiliares, serventias e órgãos prestadores de serviços notariais e de registro que atuem por delegação do poder público ou oficializados, sem prejuízo da competência disciplinar e correcional dos tribunais, podendo avocar processos disciplinares em curso e determinar a remoção, a disponibilidade ou a aposentadoria com subsídios ou proventos proporcionais ao tempo de serviço e aplicar outras sanções administrativas, assegurada ampla defesa; IV - representar ao Ministério Público, no caso de crime contra a administração pública ou de abuso de

${ }^{191}$ Para uma abordagem sobre o papel do Conselho Nacional de Justiça na implementação do processo judicial eletrônico, cf. Martinez, 2012, pp. 190-203.

${ }^{192}$ Conselho Nacional de Justiça, 2010. 
autoridade; V - rever, de ofício ou mediante provocação, os processos disciplinares de juízes e membros de tribunais julgados há menos de um ano; VI - elaborar semestralmente relatório estatístico sobre processos e sentenças prolatadas, por unidade da Federação, nos diferentes órgãos do Poder Judiciário; VII - elaborar relatório anual, propondo as providências que julgar necessárias, sobre a situação do Poder Judiciário no País e as atividades do Conselho, o qual deve integrar mensagem do Presidente do Supremo Tribunal Federal a ser remetida ao Congresso Nacional, por ocasião da abertura da sessão legislativa".

Além das competências conferidas constitucionalmente, como visto acima, e das competências estabelecidas no Estatuto da Magistratura, são atribuições do Conselho Nacional de Justiça: (i) na Política Judiciária: zelar pela autonomia do Poder Judiciário e pelo cumprimento do Estatuto da Magistratura, expedindo atos normativos e recomendações; (ii) na Gestão: definir o planejamento estratégico, os planos de metas e os programas de avaliação institucional do Poder Judiciário; (iii) na Prestação de Serviços ao Cidadão: receber reclamações, petições eletrônicas e representações contra membros ou órgãos do Judiciário, seus serviços auxiliares, serventias e órgãos prestadores de serviços notariais e de registro que atuem por delegação do poder público ou oficializado; (iv) na Moralidade: julgar processos disciplinares, assegurada ampla defesa, podendo determinar a remoção, a disponibilidade ou a aposentadoria com subsídios ou proventos proporcionais ao tempo de serviço e aplicar outras sanções administrativas; (v) na Eficiência dos Serviços Judiciais: propor melhores práticas, buscando a celeridade, elaborar e publicar semestralmente relatório estatístico sobre movimentação processual e outros indicadores pertinentes à atividade jurisdicional em todo o País.

Como se verificou acima, a Constituição concede ao Conselho poderes discricionários delimitados pelas regras de competência do art. 103-B e pelos princípios gerais aplicáveis à Administração Pública do art. 37. Desses poderes discricionários decorrem poderes administrativos "inerentes" ou "implícitos". 193

Com efeito, quando a Constituição confere ao Conselho a competência de fiscalizar a atuação administrativa do Poder Judiciário e fazer cumprir o art. 37, implicitamente concede os poderes necessários para o exercício eficaz dessa competência.

\footnotetext{
${ }^{193}$ Nesse sentido foi o voto do Ex-Ministro Ayres Britto, do Supremo Tribunal Federal, na relatoria da Ação Declaratória de Constitucionalidade n. 7.
} 
José Afonso da Silva relata que se cogitou "a ideia de um órgão de controle externo da administração da Justiça que tivesse, entre suas incumbências, o planejamento e a preparação da proposta orçamentária do Poder Judiciário" ${ }^{194}$. Entretanto, o Conselho criado pela Emenda Constitucional n. 45/2004 não recebeu essa atribuição, só cumprindo a ele, nesse particular, o controle da atuação administrativa e financeira do Poder Judiciário.

Segundo Gustavo Guerra, pode-se distinguir duas categorias básicas de atribuições do Conselho Nacional de Justiça. Há, por um lado, a categoria precípua ou primária, consistente nos atos típicos de controle da conduta dos magistrados e do planejamento das ações do sistema judicial. Por outro lado, existe uma categoria segmentada ou político-estruturante, caracterizada por programas, recomendações, rotinas de padronização e interlocuções dentro dos mais variados segmentos da governança pública. ${ }^{195}$

De acordo com Carvalho Filho, é possível classificar as atribuições do Conselho Nacional de Justiça em quatro grupos, a saber: (i) controle financeiro e administrativo do Poder Judiciário; (ii) controle institucional, incidente sobre $\mathrm{o}$ cumprimento dos deveres funcionais dos juízes; (iii) observância das atribuições do Estatuto da Magistratura; (iv) cumprimento das atribuições relacionadas nos incisos I a VI do parágrafo $4^{\mathrm{o}}$ do art. 103-B da Constituição. ${ }^{196}$

José Adércio Leite Sampaio, por sua vez, sistematiza as atribuições do Conselho Nacional de Justiça em seis grupos: (i) atribuições políticas; (ii) atribuições de controle administrativo; (iii) atribuições de ouvidoria; (iv) atribuições correcionais e disciplinares; (v) atribuições sancionatórias; e (vi) atribuições informativa e propositiva. ${ }^{197}$

Antonio Rulli Netto ${ }^{198}$ classifica as funções de controle exercidas pelo Conselho Nacional de Justiça em três grupos: regulamentar - que pode se dar por pedido de providências; fiscalizatório - normalmente desencadeado por procedimento de controle administrativo ou por representação por excesso de prazo; e disciplinar - desencadeado por reclamação disciplinar ou de ofício.

\footnotetext{
${ }^{194}$ Silva, 2005, p. 590.

${ }_{195}$ Guerra, 2010, p. 119.

${ }^{196}$ Carvalho Filho, 2010, p. 19.

${ }^{197}$ Sampaio, 2007, pp. 273-303

${ }^{198}$ Rulli Neto, 2007, pp. 241-244.
} 
De acordo com Maria Tereza Sadek ${ }^{199}$, a definição das competências do Conselho Nacional de Justiça está diretamente relacionada com a discussão sobre a amplitude deste órgão encarregado de exercer o controle do Judiciário. Por esta razão, o rol de atribuições tende a aumentar e a incidir sobre temas mais centrais a medida que a caracterização da instituição aproxima-se de um órgão de fiscalização e de cobrança de responsabilidades. E, inversamente, serão mais estreitas as atribuições quanto menores e menos centrais as áreas sobre as quais têm poder de monitorar e aplicar sanções.

Por sua vez, Alexandre de Moraes considera que a atuação constitucional do Conselho Nacional de Justiça direciona-se para duas importantes missões: o controle da atuação administrativa e financeira do Poder Judiciário e o controle do cumprimento dos deveres funcionais dos juízes. Deve-se observar, contudo, ressalva Alexandre de Moraes, que as duas hipóteses apresentam "uma importante e significativa diferença de atuação" do Conselho Nacional de Justiça. ${ }^{200}$

No exercício de sua função correcional e disciplinar dos membros, órgãos e serviços do Poder Judiciário, o Conselho atua como órgão administrativo hierarquicamente superior, podendo analisar tanto a legalidade quanto o mérito de eventuais faltas funcionais. $^{201}$

Diversamente, porém, na função de controle da atuação administrativa e financeira do Poder Judiciário, inclusive com a possibilidade de desconstituição ou revisão dos atos administrativos praticados pelos membros ou órgãos judiciários, o Conselho somente poderá analisar a legalidade do ato, e não o mérito, na hipótese de atos administrativos discricionários. Vale enfatizar: em relação aos atos administrativos vinculados, como a lei determina todos os seus elementos, o controle será pleno, pois inexiste vontade subjetiva da administração dos membros ou órgãos dos Tribunais na sua edição; por outro lado, nos atos administrativos discricionários expedidos pelo Poder Judiciário, o Conselho Nacional de Justiça só pode apreciar a legalidade e a moralidade da conveniência e oportunidade que fundamentaram o ato. ${ }^{202}$

Obviamente, não são poucas as competências e atribuições do Conselho Nacional de Justiça. Adicione-se a isso o fato de que a enumeração das competências atribuídas contém poderes de atuação com marcas de alguma fluidez e indefinição. Porém,

\footnotetext{
${ }^{199}$ Sadek, 2001, p. 93.

${ }^{200}$ Moraes, 2009, pp. 529-530.

${ }^{201}$ Moraes, 2009, p. 530.

202 Moraes, 2009, pp. 529-531.
} 
como ocorre com todos e quaisquer órgãos e agentes públicos, não há espaço para competências ilimitadas. ${ }^{203}$ Nesse sentido, cumpre lembrar a afirmação de Carvalho Filho, para quem "a competência de órgãos estatais somente se legitima se a ordem jurídica tiver fixado os respectivos parâmetros". ${ }^{204}$

Embora seja bastante claro o rol de competências arroladas constitucional e infraconstitucionalmente, não tem sido muito fácil identificar, com precisão, o real alcance das competências relacionadas e os limites dentro dos quais se revela legítimo exercê-las dentro dos parâmetros constitucionais.

Ao contrário, a discussão sobre alguns casos concretos e, da mesma forma, os estudos produzidos acerca dos Conselhos "têm demonstrado profunda e compreensível perplexidade sobre a matéria". ${ }^{205}$

Para José dos Santos Carvalho Filho,

\begin{abstract}
"a prova mais contundente de que os limites da atuação dos Conselhos [de Justiça e do Ministério Público] ainda são objeto de certa hesitação entre os estudiosos e Tribunais consiste na natureza das questões levadas ao Supremo Tribunal Federal. Algumas decisões convalidam as resoluções dos Conselhos, ao passo que outras lhes declaram a nulidade, fundadas em diversas razões de ordem constitucional". ${ }^{206}$
\end{abstract}

Após esta análise, José dos Santos Carvalho Filho sistematiza os pontos a serem estudados, de forma mais aprofundada, do seguinte modo: "(i) os limites do poder normativo dos órgãos; (ii) a adequação à autonomia dos entes federativos estaduais no que concerne ao Judiciário e ao Ministério Público; (iii) as condições para o exercício do controle administrativo e financeiro; (iv) o poder revisional sobre processos disciplinares; (v) a natureza e conteúdo da matéria objeto das resoluções". ${ }^{207}$

Cumpre ponderar, ainda, que "o CNJ não é um conselho da magistratura, mas um conselho do sistema de Justiça" e, portanto, "a complexidade que envolve seu

\footnotetext{
${ }^{203}$ Carvalho Filho, 2010, p. 37.

${ }^{204}$ Carvalho Filho, 2010, p. 38.

${ }^{205}$ Sampaio, 2007, p. 275.

${ }^{206}$ Carvalho Filho, 2010, p. 32.

${ }^{207}$ Carvalho Filho, 2010, p. 34.
} 
trabalho gera severas controvérsias sobre seu papel". ${ }^{208}$ Nesse sentido, Gustavo Guerra acrescenta que em apenas poucos anos de atuação

“o Conselho Nacional de Justiça promoveu profundas alterações, não apenas no Judiciário, mas no Estado brasileiro, de maneira geral. Suas competências funcionais e materiais, longe de serem apenas dirigidas ao planejamento do judiciário e o uso da força disciplinar que the foi atribuída, passou a desencadear práticas e ações que ampliam de forma visceral a governança democrática." 209

Deve ser apresentado, também, o registro feito por Janaína Penalva e Adriene Costa:

"Como fator de incremento do sistema jurídico, a criação do Conselho Nacional de Justiça agregou complexidade sistêmica. Um novo órgão com previsão constitucional certamente resolveu impasses e dificuldades, mas, da mesma forma, criou novos problemas e desafios a serem enfrentados. (...) Como instância inovadora de formulação de políticas judiciárias, assim como espaço mais efetivo de controle disciplinar, o CNJ a todo tempo provoca reformulações nas estruturas internas do Judiciário. Neste aspecto, talvez a questão mais difícil que o CNJ tenha trazido ao sistema jurídico seja exatamente sua relação com o Supremo Tribunal Federal. $" 210$

Dessa forma, diante desse amplo feixe de competências e de atividades desempenhadas pelo Conselho Nacional de justiça, e não se olvidando que a literatura jurídica brasileira volta-se com distinta ênfase - qualitativa e quantitativamente - às diferentes competências, enfoca-se, no presente trabalho, a competência disciplinar.

\footnotetext{
${ }^{208}$ Guerra, 2010, p. 4.

${ }^{209}$ Guerra, 2010, p. 159.

${ }^{210}$ Penalva e Costa, 2010 , sem paginação.
} 
Antes, contudo, de se passar ao próximo capítulo, cabem ainda neste item "Competências, atribuições e aspectos institucionais relevantes" algumas observações finais.

Além do rol apresentado no artigo 103-B, parágrafo $4^{\circ}$, da Constituição da República, acima apresentado, há outras competências atribuídas ao Conselho esparsamente apontadas no texto constitucional, visando concatenar suas funções e sua atuação à estrutura do Poder Judiciário brasileiro. Com efeito, existem ainda três outros dispositivos constitucionais que guardam relação direta com a estrutura e o funcionamento do Conselho Nacional de Justiça. São eles: o art. 93, inciso VIII; o art. 100, parágrafo $7^{\text {; }}$ e o art. 102, inciso I, alínea "r".

De acordo com o art. 93, VIII, o ato de remoção, disponibilidade e aposentadoria do magistrado, por interesse público, fundar-se-á em decisão por voto da maioria absoluta do respectivo tribunal ou do Conselho Nacional de Justiça, assegurada ampla defesa. Tal dispositivo apresenta-se importante ao exercício da competência disciplinar do Conselho, na medida em que lhe possibilita a aplicação de sanções em decorrência de infrações devidamente apuradas e julgadas em sede, por exemplo, de procedimento administrativo disciplinar.

Também relacionada com a competência disciplinar - e fiscalizatória - do Conselho, é a norma contida no parágrafo $7^{\circ}$ do art. 100 da Constituição da República, a qual determina que, além de incorrer em crime de responsabilidade, responderá também perante o Conselho Nacional de Justiça o Presidente do Tribunal competente que, por ato omissivo ou comissivo, retardar ou tentar frustrar a liquidação regular de precatórios.

Finalmente, apresente-se a norma constitucionalmente prevista no art. 102, I, "r", que estabelece a competência do Supremo Tribunal Federal para o julgamento das ações contra o Conselho Nacional de Justiça e o Conselho Nacional do Ministério Público. Trata-se de disposição lógica e decorrente tanto das atribuições especiais do Conselho, como em razão dos membros que o compõe. 


\title{
CAPÍTULO III
}

\author{
ENTENDIMENTO JURISPRUDENCIAL ACERCA DA \\ CONSTITUCIONALIDADE DA CRIAÇÃO DO CONSELHO \\ NACIONAL DE JUSTIÇA: AS PRINCIPAIS DEFINIÇÕES A PARTIR \\ DOS JULGAMENTOS DA ADI N. 3367 E DA ADC N. 12
}

\section{III.1. Considerações Iniciais}

No presente capítulo, será apresentado o entendimento jurisprudencial acerca da constitucionalidade da criação do Conselho Nacional de Justiça brasileiro.

Neste ponto, considera-se que as mais relevantes decisões jurisprudenciais relativas ao Conselho, em sede de controle de constitucionalidade, foram proferidas pelo Supremo Tribunal Federal primeiramente no julgamento da Ação Direta de Inconstitucionalidade n. 3367, no ano de 2005 e, posteriormente, no julgamento da Ação Declaratória de Constitucionalidade n. 12, no ano de 2006.

Logo após a instituição do Conselho, e antes mesmo da publicação da Emenda Constitucional n. 45, em 31 de dezembro de 2004, a Associação dos Magistrados Brasileiros, impulsionada pelos infindáveis questionamentos em torno da legitimidade da criação de um órgão de controle do Poder Judiciário, propôs uma Ação Direta questionando sua constitucionalidade.

Analisando-se a petição inicial da ADI n. 3367, verifica-se que os principais argumentos trazidos em sua fundamentação foram: "ofensa à cláusula constitucional da repartição e independência dos poderes"; “desrespeito ao pacto federativo, na medida em que submeteu os órgãos do Poder Judiciário dos Estados a uma supervisão administrativa, orçamentária, financeira e disciplinar por órgão da União Federal”; “as competências atribuídas ao Conselho Nacional de Justiça são competências dos próprios tribunais, impostas legislador constituinte originário"; inconstitucionalidade da composição heterogênea do Conselho Nacional de Justiça; "a sobreposição das competências do 
Conselho Nacional de Justiça às competências do Conselho de Justiça Federal e do Conselho Superior da Justiça do Trabalho"; "inconstitucionalidade formal do inciso III, $\S 4^{\circ}$, do art. 103-B, porque não teria sido votado nas duas casas do Congresso Nacional, violando o $\S 2^{\circ}$, do art. 60, da Constituição da República”.

Curiosamente, apenas uma ano depois do ajuizamento da ação de inconstitucionalidade, a Associação dos Magistrados Brasileiros ajuizou uma Ação Declaratória de Constitucionalidade que teve por objeto a análise da conformidade da Resolução n. $7^{211}$ do Conselho Nacional de Justiça à Constituição da República.

Conhecida por seu objetivo de combate ao nepotismo, tal resolução tem por objeto a disciplina do exercício de cargos, empregos e funções por parentes, cônjuges e companheiros de magistrados e de servidores investidos em cargos de direção e assessoramento, no âmbito dos órgãos do Poder Judiciário.

Por ocasião do julgamento de tais ações, o Supremo Tribunal Federal teve oportunidade de, em sede de controle concentrado de constitucionalidade, analisar a constituição de um novo órgão integrante do próprio Judiciário à luz de alguns dos pilares do sistema constitucional brasileiro - repartição de poderes, federalismo, autonomia do Poder Judiciário.

No âmbito desta dissertação, é oportuna a menção ao conteúdo essencial emanado destes dois importantes julgamentos pela Suprema Corte, com o objetivo de delinear, de forma mais adequada, os contornos das competências atribuídas ao Conselho Nacional de Justiça.

É importante acrescentar que a preocupação que norteia a redação deste capítulo é mais com o registro do entendimento jurisprudencial do Supremo Tribunal Federal acerca do Conselho do que propriamente com uma análise da pertinência ou não deste entendimento, ou com o estudo aprofundado de cada um dos temas em análise. ${ }^{212}$

\footnotetext{
${ }^{211}$ No MS 25.938-8 - DF, de relatoria da Ministra Cármen Lúcia, o Supremo reconheceu que, expedida no exercício da competência normativa do Conselho Nacional de Justiça, a Resolução n. 07/2005 tem caráter ato normativo, genérico, abstrato e impessoal: “A Resolução n. 07/05 do CNJ reveste-se dos atributos da generalidade (os dispositivos dela constantes veiculam normas proibitivas de ações administrativas de logo padronizadas), impessoalidade (ausência de indicação nominal ou patronímica de quem quer que seja) e abstratividade (trata-se de um modelo normativo com âmbito temporal de vigência em aberto, pois claramente vocacionado para renovar de forma contínua o liame que prende suas hipóteses de incidência)".

${ }^{212} \mathrm{O}$ que poderia ensejar a redação de diversas teses sobre aspectos de cada um dos temas - separação de poderes, federalismo, independência do Judiciário, poder regulamentar etc.
} 


\section{III.2. CNJ e repartição de Poderes}

Após uma análise de caráter histórico e um considerável estudo de revisão de doutrina político-jurídica que inspira e explica a teoria constitucional da repartição de funções pelos Poderes constitucionalmente estabelecidos, o ex-Ministro Cezar Peluso, do Supremo Tribunal Federal, no exercício da relatoria na Ação Direta de Inconstitucionalidade n. 3367, entendeu que não se pode conceber que a criação do Conselho Nacional de Justiça ofenda a repartição de poderes, no que foi acompanhado pela maioria dos Ministros ${ }^{213}$.

Com efeito, consignou em seu voto que, sob o prisma constitucional brasileiro do sistema da separação dos Poderes, não se vê como possa ofendê-lo a criação do Conselho Nacional de Justiça.

Para tanto, justificou, em um primeiro momento, que à luz da estrutura que lhe deu a Emenda Constitucional n. 45, de 2004, trata-se de órgão integrante do próprio do Poder Judiciário ${ }^{214}$, composto, na maioria, por membros desse mesmo Poder $^{215}$, nomeados sem interferência direta dos outros Poderes, dos quais o Legislativo apenas indica, fora de seus quadros e, portanto, sem laivos de representação orgânica, dois dos quinze membros e que, tal indicação "significa mera representação simbólica da instância legislativa, não podendo equiparar-se a nenhuma forma de intromissão incompatível com a ideia política e o perfil constitucional da separação e independência dos Poderes". ${ }^{216}$

Além disso, ponderou que a independência, "como predicado essencial do sistema da separação", somente pode ser considerada invulnerável "quando concreta redução de seu âmbito primitivo" ocasione "dano do equilíbrio e estabilidade entre os Poderes", ou ainda "transferência de prerrogativas a outro deles", mesmo que com isso "não chegue a caracterizar submissão política".

\footnotetext{
213 A decisão foi tomada por maioria (sete votos em onze); ficaram vencidos os ministros Ellen Gracie e Carlos Velloso (que tinham por inconstitucional a participação, no CNJ, de membros do Ministério Público, da advocacia e de cidadãos indicados pelo Legislativo), Sepúlveda Pertence (que restringia sua insurgência ao inciso XIII, que prevê a indicação, pelo Legislativo, de dois cidadãos) e Marco Aurélio (que entendia inconstitucional todo o artigo 103-B, por afrontar a independência do Judiciário).

${ }^{214}$ Constituição da República, art. 92, I-A.

${ }^{215}$ Constituição da República, art. 103-B.

${ }^{216}$ Trecho do voto do Ex-Ministro Cezar Peluso, na relatoria da ADI 3367.
} 
Especificamente no que se refere ao Judiciário, a independência entre os Poderes somente o afetaria realmente, a ponto de ferir o princípio da repartição de poderes, “quando a supressão de atribuições degrade ou estreite a imparcialidade jurisdicional". ${ }^{217}$

Além disso, registrou, no que tange à vida orgânica do Judiciário, que merece atenção especial a competência do Executivo para nomear parte dos membros do Poder $^{218}$, como se dá com integrantes da Justiça Eleitoral ${ }^{219}$, dos Tribunais Regionais Federais, dos Tribunais estaduais e do Distrito Federal, por via do chamado quinto constitucional $^{220}$, e dos próprios Ministros do Supremo, cuja investidura depende ainda de aprovação do Senado ${ }^{221}$.

A menção a tais casos prova, segundo o Ex-Ministro Cezar Peluso, que

\begin{abstract}
“a incorporação privilegiada do princípio da separação na ordem constitucional não significa de modo algum que a distribuição primária das funções típicas e a independência formal dos Poderes excluam regras doutro teor, que, suposto excepcionais na aparência, tendem, no fundo, a reafirmar a natureza unitária das funções estatais, a cuja repartição orgânica é imanente a vocação conjunta de instrumentos da liberdade e da cidadania. Tal arrumação normativa está longe de fraturar ou empobrecer o núcleo político e jurídico do sistema, que só estará mortalmente ferido lá onde se caracterizar, à luz de sua inspiração primordial, usurpação de funções típicas ou aniquilamento prático da autonomia de cada Poder" ${ }^{222}$
\end{abstract}

Em conclusão, afirmou-se no voto condutor do julgamento da ADI 3367, que "está no valor político supremo da imparcialidade dos juízes e tribunais o critério decisivo da estima da compatibilidade do Conselho Nacional de Justiça, com todas as provisões constitucionais de um Judiciário independente", em sintonia com a doutrina da repartição de poderes. ${ }^{223}$

\footnotetext{
${ }^{217}$ Trecho do voto do Ex-Ministro Cezar Peluso, na relatoria da ADI 3367.

${ }^{218}$ Trecho do voto do Ex-Ministro Cezar Peluso, na relatoria da ADI 3367.

${ }^{219}$ Constituição da República, arts. 119, inc. II, e 120, inc. III.

${ }^{220}$ Constituição da República, art. 94.

${ }^{221}$ Constituição da República, art. 101, parágrafo único.

${ }^{222}$ Trecho do voto do Ex-Ministro Cezar Peluso, na relatoria da ADI 3367.

${ }^{223}$ Trecho do voto do Ex-Ministro Cezar Peluso, na relatoria da ADI 3367.
} 
No julgamento da Ação Declaratória de Constitucionalidade n. 7, por diversas vezes, foi feita menção ao importante precedente constituído pela ADI 3367 . No que se refere ao tema em análise, registrou-se que "o modelo normativo em exame [da conformação constitucional do Conselho Nacional de Justiça] não é suscetível de ofender a pureza do princípio da separação dos Poderes [e do princípio federativo]"224, reforçando a menção ao fato de o Conselho não é órgão estranho ao Poder Judiciário, não se submetendo à autoridade de nenhum dos outros dois Poderes.

\section{III.3. CNJ e princípio federativo}

No capítulo anterior, afirmou-se que o Conselho Nacional de Justiça é um órgão do Poder Judiciário, de natureza constitucional, autônomo administrativa e funcionalmente, que desempenha funções político-administrativas relativas ao Poder que integra, com atuação em todo o território nacional.

Com efeito, o Conselho constitui-se em um órgão judicial nacional, que promove, dentre outras atividades, a uniformização de determinados procedimentos e instituições para todos os tribunais federais e estaduais.

O Judiciário, assim como o Executivo e o Legislativo, é composto por entes da União e dos Estados-membros. O Conselho Nacional de Justiça, contudo, não é concebido nem estruturado como órgão da União, e, sim, do Poder Judiciário nacional. Este entendimento permeou a análise, feita na Ação Direta de Constitucionalidade n. 3367, da questão da compatibilidade do Conselho com o princípio federativo no sistema constitucional brasileiro.

Com efeito, no julgamento de referida ação, considerou-se que não prejudica este entendimento - que aponta para o caráter nacional do Conselho - o fato de que seu orçamento seja federal, pois "a origem da fonte de custeio não transmuda a natureza nem a relação de pertinência do órgão no plano da separação dos Poderes”, que é o plano em que se situa "o critério de sua taxinomia, que nada tem com outro plano classificatório, o das unidades da federação”. Deve-se ter em consideração, nesse sentido,

\footnotetext{
${ }^{224}$ Adiante-se, neste ponto, que o registro já informa o tema a ser analisado na sequência.
} 
“o plano lógico em que está o critério de divisão dos órgãos do mesmo Poder”, não apenas o plano que "discerne entre as entidades elementares da federação". Considerando apenas este aspecto orçamentário, caracterizá-lo como órgão federal seria “tão impróprio quanto supor que o Supremo Tribunal Federal e o Superior Tribunal de Justiça, por exemplo, não pudessem julgar recursos interpostos em causas da competência de órgãos jurisdicionais estaduais, ou de interesse de municípios", com a justificativa de que "o custeio de ambos corre à conta do orçamento da União". 225

Também não se podem estabelecer comparações entre Conselho e os Executivos e Legislativos estaduais e municipais, porque estes não constituem Poderes nacionais, mas apenas "se situam, definem e qualificam dentro das respectivas camadas da federação". E tampouco se pode imaginar que haveria supervisão administrativa, orçamentária, financeira e disciplinar dos órgãos judiciários estaduais por órgão da União. "Não vejo, pois, como cogitar de violação ao princípio federativo". 226

O Conselho não é órgão da União. Sua composição reverencia e contempla as duas esferas federativas dotadas de Justiças, a União e os Estados-membros, os quais contam ali com representantes das respectivas magistraturas ${ }^{227}$. Além disso, a indicação de um cidadão pelo Senado Federal exprime de certa maneira, senão a vontade, pelo menos forma indireta de participação dos Estados $^{228}$.

Acrescentou o Ministro Gilmar Mendes, no julgamento da Ação Declaratória n. 7 - e o que é ponderado aqui importa diretamente ao estudo específico da competência disciplinar do Conselho - que, à vista desta sua característica de órgão de feição nacional,

"pode-se afirmar, primeiro, que, no seu escopo constitucional de competências, a atuação do CNJ dar-se-á "sem prejuízo da competência disciplinar e correcional dos tribunais" (art. 103-B, $\S 4^{\circ}$, inciso III) - ou seja, não substitui, por eliminação, a competência própria às diversas Cortes de Justiça -, mas também sem que, em outro extremo, esteja ela limitada a alguma função recursal ou revisora desta atuação local: o CNJ,

\footnotetext{
${ }^{225}$ Trecho do voto do Ex-Ministro Cezar Peluso, na relatoria da ADI 3367.

226 Trecho do voto do Ministro Gilmar Mendes, proferido no julgamento da Ação Declaratória de Constitucionalidade n. 07.

${ }^{227}$ Constituição da República, art. 103-B, I a IX.

${ }^{228}$ Constituição da República, art. 103-B, XIII.
} 
na matéria que lhe é própria, é funcionalmente primus inter pares, pois atua nacionalmente e em caráter vinculativo para os Tribunais do país, podendo (e devendo) estes atuar, no exercício daquela competência disciplinar e correcional, sempre que assim autorizado pelo CNJ ou que não seja incompatível com as suas normas, orientações, decisões e determinações. $^{229}$

Ademais, também se pode afirmar, especialmente se for considerado, em adição, a ausência de competência legislativa geral, de sede constitucional, para a disciplina dos temas próprios ao funcionalismo público - “é um dos exemplos clássicos, no nosso modelo, de competência legislativa comum" -, que a criação do Conselho instituiu no sistema constitucional brasileiro "autoridade administrativa" com poderes normativos e executórios, “cuja parametração, exclusivamente na matéria que lhe é própria, é nacional e unitariamente impositiva às autoridades judiciárias - em caráter direto - e às demais autoridades do Estado brasileiro - em caráter indireto". 230

Dessa forma, ponderou-se que, no âmbito de sua competência, o Conselho "atua sobrepondo-se inclusive à legislação não-nacional - ou seja, federal, em sentido estrito, estadual ou, se for o caso, municipal". 231

Explicou-se que tal característica assim se revela porque é "inerente ao modelo federativo brasileiro que nos temas constitucionalmente reservados à atuação, exclusiva ou concorrente, em âmbito nacional", as normas, orientações, decisões e determinações de caráter "federal" se sobreponham àquelas de âmbito meramente "local" (“ou seja, reitere-se, federal - em sentido estrito -, estadual ou municipal”), com a ressalva de que "estas últimas validamente existam, porém desde que assim o seja em compatibilidade com o parâmetro nacional (ou na sua inexistência, enquanto esta situação perdurar) e para atender a peculiaridades locais". Além disso, consignou-se que "a preservação do caráter nacional e do regime orgânico unitário do Poder Judiciário não permite, ou não deve mais permitir, a existência de disparidades jurídicas locais ou

\footnotetext{
229 Trecho do voto do Ministro Gilmar Mendes, proferido no julgamento da Ação Declaratória de Constitucionalidade n. 07. Sem destaque no original.

${ }^{230}$ Trecho do voto do Ministro Gilmar Mendes, proferido no julgamento da Ação Declaratória de Constitucionalidade n. 07.

231 Trecho do voto do Ministro Gilmar Mendes, proferido no julgamento da Ação Declaratória de Constitucionalidade n. 07.
} 
regionais" que não possam ser justificadas pela "estrita necessidade de adaptação a peculiaridades locais legítimas e de acordo com o interesse público". 232

Não se pode esquecer, por fim, que em sua atuação o Conselho Nacional de Justiça vincula-se não apenas às normas constitucionais e às suas próprias regras de funcionamento - no que se refere a aspectos procedimentais -, mas também aos conceitos jurídicos previamente estabelecidos na legislação de âmbito nacional ${ }^{233}$.

Ainda no julgamento da Ação Declaratória de Constitucionalidade n. 7, relativamente ao tema do federalismo, apresentaram-se outras duas justificativas para a compatibilidade do Conselho com aquele principio, sendo a primeira delas consistente no reconhecimento de que "o Poder Judiciário tem uma singular compostura de âmbito nacional, perfeitamente compatibilizada com o caráter estadualizado de uma parte dele". Ademais, de acordo com o art. 125, caput, da Constituição da República ${ }^{234}$, defere-se aos Estados a competência de organizar a sua própria Justiça, estando tal organização jungida aos princípios estabelecidos na própria Constituição, neles incluídos os constantes do art. 37 . $^{\text {aput. }}{ }^{235}$

Concluiu-se, no julgamento da ADI n. 3367, que "o Conselho não anula, antes reafirma o princípio federativo" 236 , entendimento este posteriormente ratificado no âmbito da ADC n. 12.

\section{III.4. CNJ e independência e responsabilização da Magistratura}

Afirmou-se, na Ação Direta de Inconstitucionalidade n. 3367, que o Poder Judiciário tem caráter nacional e "regime orgânico unitário, sendo este precisamente a premissa maior pela qual não ofende a sua autonomia a instituição de um órgão próprio à

${ }^{232}$ Trecho do voto do Ministro Gilmar Mendes, proferido no julgamento da Ação Declaratória de Constitucionalidade n. 07.

${ }^{233}$ Trecho do voto do Ministro Gilmar Mendes, proferido no julgamento da Ação Declaratória de Constitucionalidade n. 07, em que se acrescenta: "como ocorre, primeiramente, com a Lei Orgânica da Magistratura (art. 93 da CF, ou até o seu advento a Lei Complementar n. 35), e ainda, exemplificativamente e tendo em vista a singularidade da controvérsia aqui analisada, com as regras do Código Civil relativas à caracterização do parentesco (sanguíneo ou civil) - exemplos similares, no âmbito das competências constitucionais do CNJ, poderia ocorrer com a Lei de Licitações ou com a Lei de Responsabilidade Fiscal".

234 “Art. 125. Os Estados organizarão sua Justiça, observados os princípios estabelecidos nesta Constituição".

${ }^{235}$ Ementa do julgamento da ADC n. 12.

${ }^{236}$ Trecho do voto do Ex-Ministro Cezar Peluso, na relatoria da ADI 3367. 
sua estrutura e harmônico à sua composição para o controle administrativo, financeiro e disciplinar de sua atuação administrativa”.

Quanto à questão da preocupação com comprometimento da independência da magistratura, o Supremo Tribunal Federal entendeu que a ideia de independência suporta, na sua feição constitucional, teores diversos da autonomia administrativa, financeira e disciplinar.

Conduzida pelo voto do Ministro Relator Cezar Peluso, a Suprema Corte entendeu que nada obsta o "redesenho da configuração histórica da independência pelo constituinte reformador", mediante reorganização orgânica e redistribuição de competências no âmbito da estrutura interna do judiciário, "sem perda nem deterioração das condições materiais de isenção e imparcialidade dos juízes”. 237

Com efeito, pode-se dizer que são duas as ordens de atribuições conferidas ao Conselho pela Emenda Constitucional n. 45/2004: o controle da atividade administrativa e financeira do Judiciário, e o controle ético-disciplinar de seus membros.

A primeira não atinge o autogoverno do Judiciário, pois "da totalidade das competências privativas dos tribunais" $" 238$, nenhuma foi retirada deles, "que continuarão a exercê-las todas com plenitude e exclusividade", elegendo os corpos diretivos, organizando as secretarias e serviços auxiliares, elaborando os regimentos internos, provendo os cargos de juiz de carreira, desempenhando os atos necessários à administração da justiça, "sem terem perdido o poder de elaborar e encaminhar as respectivas propostas orçamentárias". ${ }^{239}$

Não se pode esquecer o caráter não-absoluto da independência constitucional do Poder. Afora as limitações concernentes à elaboração dos orçamentos, a criação ou extinção dos tribunais, a alteração do número de seus membros, a modificação da organização e da divisão judiciárias, bem como a criação de cargos e a remuneração dos serviços auxiliares e dos juízos vinculados ao Supremo Tribunal Federal, aos Tribunais Superiores e aos Tribunais de Justiça também dependem da aprovação do Poder Legislativo, o que demonstra que as garantias do art. 96 da Constituição objetivam fundamentalmente estabelecer a independência do Poder Judiciário em relação aos demais Poderes. "Mas se é absoluta essa independência no que respeita ao desempenho de suas

\footnotetext{
${ }^{237}$ Trecho do voto do Ex-Ministro Cezar Peluso, na relatoria da ADI 3367.

${ }^{238}$ Objeto do disposto no art. 96 da Constituição da República

${ }^{239}$ Trecho do voto do Ex-Ministro Cezar Peluso, na relatoria da ADI 3367.
} 
funções, não se pode dizer o mesmo no tocante à organização do Poder Judiciário, a qual depende frequentemente do Poder Executivo ou do Legislativo, quando não de ambos". ${ }^{240}$

A segunda modalidade de atribuições do Conselho, que se refere ao controle do cumprimento dos deveres funcionais dos juízes não hostiliza imparcialidade jurisdicional. Com efeito, e este ponto será abordado com maiores detalhes no Capítulo IV

\begin{abstract}
"representa expressiva conquista do Estado democrático de direito, a consciência de que mecanismos de responsabilização dos juízes por inobservância das obrigações funcionais são também imprescindíveis à boa prestação jurisdicional - "a responsabilidade judicial é a outra face da moeda da independência, a sua contrapartida". E a necessidade, enfatizou, de se coordenarem essas exigências, põe-nos, como bem o percebeu o saudoso Mauro Cappelletti, diante de "um problema de equilíbrio entre o valor de garantia e instrumental da independência, externa e interna, dos juízes, e o outro valor moderno (mas também antigo, como se viu) do dever democrático de prestar contas". ${ }^{241}$
\end{abstract}

Longe de constituir um insulto à independência judicial, "a criação de um órgão com poderes de controle nacional dos deveres funcionais dos magistrados responde a uma imperfeição contingente do Poder, no contexto do sistema republicano de governo". Conveniente, portanto, a existência de um órgão controlador, integrado, em sua maioria, por magistrados, mas também por profissionais de outras áreas jurídicas, "como se tem feito para compor bancas examinadoras de concursos de ingresso na magistratura".

Não se pode esquecer que "o Poder Judiciário exerce poder público, age em nome do povo, embora seus membros não sejam escolhidos por meio de eleição popular". Por esta razão é "necessário um controle democrático de seu desempenho, que assegure a obediência às regras legais e a prevalência do interesse público, mantendo o requisito fundamental, que é a garantia da independência dos juízes". ${ }^{242}$

\footnotetext{
${ }^{240}$ Trecho do voto do Ex-Ministro Cezar Peluso, na relatoria da ADI 3367.

${ }^{241}$ Trecho do voto do Ex-Ministro Cezar Peluso, na relatoria da ADI 3367. É importante registrar que neste trecho o Relator vale-se dos ensinamentos de Mauro Cappelletti, em sua obra Juízes Irresponsáveis? (Cappelletti, 1989).

${ }^{242}$ Trecho do voto do Ex-Ministro Cezar Peluso, na relatoria da ADI 3367.
} 
Oportuno colacionar também o voto proferido no julgamento da ADI n. 3367 pelo Ex-Ministro Eros Grau em que ficou consignado que ao Conselho Nacional de Justiça não é atribuída competência nenhuma que permita a sua interferência na independência funcional do magistrado. Nesse sentido, caberia ao Conselho exclusivamente o "controle da atuação administrativa e financeira do Poder Judiciário e do cumprimento dos deveres funcionais dos juízes", nada mais do que isso. Sua presença, como órgão do Poder Judiciário, no modelo brasileiro de harmonia e equilíbrio entre os poderes, não conformará nem informará, nem mesmo afetará, o dever-poder de decidir conforme a Constituição e as leis que vincula os membros da Magistratura. ${ }^{243}$

Nesta mesma linha de raciocínio, o Ministro Relator da ADI n. 3367 enfatiza que "o Conselho não julga causa alguma, nem dispõe de nenhuma atribuição, de nenhuma competência, cujo exercício fosse capaz de interferir no desempenho da função típica do Judiciário, a jurisdicional". E, dessa forma, conclui que "não seria lógico nem sensato levantar suspeitas de que, sem atribuição jurisdicional, possa comprometer independência que jamais se negou a órgãos jurisdicionais integrados por juízes cuja nomeação compete ao Poder Executivo, com ou sem colaboração do Legislativo". 244

\section{III.5. Breves notas sobre o Poder Regulamentar do Conselho Nacional de Justiça}

De notável destaque nas análises feitas tanto na Ação Direta de Inconstitucionalidade n. 3367 como na Ação Declaratória de Constitucionalidade n. 12, foi o controvertido tema dos limites da atuação normativa do Conselho Nacional de Justiça. Trata-se, sem dúvida, de discussão relevante no que toca ao debate em torno da atuação do Conselho, e que vem sendo objeto de acessos debates doutrinários e jurisprudenciais. ${ }^{245}$

\footnotetext{
${ }^{243}$ Trehco do voto do Ex-Ministro Eros Grau, no julgamento da ADI 3367.

${ }^{244}$ Trecho do voto do Ex-Ministro Cezar Peluso, na relatoria da ADI 3367.

${ }^{245}$ Há duas importantes ações diretas de inconstitucionalidade que versam sobre o poder regulamentar do CNJ que ainda não foram objeto de julgamento definitivo pelo Supremo Tribunal Federal (ADI 4465 Referendo-MC, Rel. Ministr Marco Aurélio, que tem por objeto a Resolução CNJ n. 115/1010, e a ADI 4638-MC, Rel. Ministr Marco Aurélio, que tem por objeto a Resolução CNJ n. 135/2011, a qual será estudada no capítulo $\mathrm{V}$ deste trabalho).
} 
Um dos motivos para tanto, no entender de Flurh $^{246}$, reside no fato de que a criação do Conselho Nacional de Justiça "não foi fruto de reflexão mais aprofundada ou de debates mais consistentes no cenário sócio-jurídico". Com isso, houve "uma fixação pouco concreta de suas atribuições e limites, e, quiçá, de uma revisão das suas competências”.

De acordo com Pedro Deocleciano ${ }^{247}$, a origem da controvérsia está na existência de lacunas tanto nas prerrogativas constitucionais quanto na LOMAN e na própria decisão que confirmou a constitucionalidade do Conselho - ADI 3367.

O cerne da questão é o alcance da norma contida no parágrafo $4^{\circ}$, inciso I, do art. 103-B ${ }^{248}$. Relacionado ao dispositivo constitucional, o art. 138 do Regimento Interno do Conselho Nacional de Justiça, dispõe que, até a entrada em vigor o Estatuto da Magistratura, o Conselho poderá, por Resolução, nos termos do art. $5^{\circ}, \S 2^{\circ}$, da Emenda Constitucional n. 45/2004, disciplinar seu funcionamento, dispor sobre a sua estrutura, direitos e deveres de seus Conselheiros, bem como sobre cargos e funções indispensáveis ao seu regular funcionamento.

Como se verificou no capítulo anterior, a Constituição concede ao Conselho poderes discricionários delimitados pelas regras de competência do art. 103-B e pelos princípios gerais aplicáveis à Administração Pública do art. 37. Desses poderes discricionários decorrem poderes administrativos "inerentes" ou "implícitos" (inherent powers, implied powers). Com efeito, quando a Constituição confere ao Conselho a competência de fiscalizar a atuação administrativa do Poder Judiciário e fazer cumprir o art. 37, implicitamente concede os poderes necessários para o exercício eficaz dessa competência.

Para Hamilton Schwartz e Christiane Pedersoli, autores de duas monografias específicas sobre o tema, não é plenamente correto invocar a experiência estrangeira, sobretudo a europeia, para embasar ao poder regulamentar do Conselho brasileiro. Justificam os seus entendimentos com quatro argumentos principais: (i) existência de presidencialismo no Brasil e de parlamentarismo ou semipresidencialismo na Europa; (ii) o Judiciário brasileiro possui uma independência única, o que levou o

\footnotetext{
${ }^{246}$ Flurh, 2012, p. 80.

${ }^{247}$ Deocleciano, 2010, p. 16.

248 " $4^{\circ}$ Compete ao Conselho o controle da atuação administrativa e financeira do Poder Judiciário e do cumprimento dos deveres funcionais dos juízes, cabendo-lhe, além de outras atribuições que lhe forem conferidas pelo Estatuto da Magistratura: I - zelar pela autonomia do Poder Judiciário e pelo cumprimento do Estatuto da Magistratura, podendo expedir atos regulamentares, no âmbito de sua competência, ou recomendar providências". Sem destaque no original.
} 
Conselho a limitar a sua atuação de maneira mais efetiva do que cumprir a sua primeira diretriz: a garantia da independência do Poder Judiciário; (iii) há, no Brasil, um sistema de jurisdição única, lembrando a existência, em alguns países da Europa, de jurisdição administrativa; (iv) o ordenamento jurídico brasileiro, diferentemente do Direito comparado, não delineou claramente a esfera jurídica na qual o regulamento pode ser editado, ou seja, as matérias que comportam regulamentação. ${ }^{249}$

No julgamento da Ação Direta de Inconstitucionalidade n. 3367, o ExMinistro Cezar Peluso, relator da ação, consignou em seu voto que a competência do Conselho para expedir atos regulamentares "destina-se, por definição mesma de regulamento heterônomo, a fixar diretrizes para execução dos seus próprios atos, praticados nos limites de seus poderes constitucionais", como consta, aliás, do art. 103-B, $\S$ $4^{\text {o }}$, I. E, complementa o Ex-Ministro, “a mesma coisa é de dizer-se a respeito do poder de iniciativa de propostas ao Congresso Nacional - art. 103-B, $\S 4^{\circ}$, inc. VII". 250

Em seus consideranda, a Resolução n. 7/05 deixa claro seu fundamento e propósito: dar cumprimento ao disposto no artigo 103-B, § 4º II, da Constituição Federal, adequando a administração do Judiciário aos parâmetros erigidos pelo artigo 37 , caput, da Carta. $^{251}$

Como foi visto no capítulo anterior, compete ao Conselho Nacional de Justiça zelar pela observância do art. 37 da Constituição da República. Assim, ao lado do controle geral de legalidade, o constituinte previu, igualmente, a fiscalização dos atos administrativos praticados pelo Judiciário à luz de um parâmetro constitucional específico: os princípios e regras do art. 37.

Para poder zelar por seu cumprimento, o Conselho Nacional de Justiça não pode estar desautorizado a identificar as condutas administrativas que considera violadoras do art. 37. Não parece haver dúvida de que, ao atribuir ao Conselho tal poder-dever, a Constituição conferiu-lhe também os meios lícitos para desincumbir-se dele. "Essa lógica está longe de ser nova e, a rigor, fundamenta toda a atuação regulamentar da Administração: quem determina os fins, concede igualmente os meios". ${ }^{252}$

\footnotetext{
${ }^{249}$ Pedersoli, 2009, pp. 65-66 e pp. 91-92; Schwartz, 2009, pp.145-146.

${ }^{250}$ Ementa do julgamento da ADI n. 3367.

${ }^{251}$ Petição Inicial da ADC n. 12, ajuizada pela Associação dos Magistrados Brasileiros (AMB), assinada pelo advogado Luís Roberto Barroso.

${ }^{252}$ Petição Inicial da ADC n. 12, ajuizada pela Associação dos Magistrados Brasileiros (AMB), assinada pelo advogado Luís Roberto Barroso.
} 
No julgamento da constitucionalidade da Resolução n. 07, de 2005, do Conselho Nacional de Justiça, feita em sede de controle de constitucionalidade - Ação Declaratória de Constitucionalidade n. 12 - a questão a que procurou responder o Supremo Tribunal Federal foi posta da seguinte forma pelo Ex-Ministro Ayres Britto, relator da ação: "o Conselho Nacional de Justiça foi aquinhoado com essa modalidade primária de competência? Mais exatamente: foi o Conselho Nacional de Justiça contemplado com o poder de expedir normas primárias sobre as matérias que servem de recheio fático ao inciso II, do $\S 4^{\circ}$, do art. 103-B da Constituição?". ${ }^{253}$

A este questionamento, respondeu-se afirmativamente, no sentido de que pode o Conselho expedir atos regulamentares no exercício de suas competências, como bem estabelece, com clareza, o próprio texto constitucional. Esclareceu o Ex-Ministro Ayres Britto, e vale a ênfase, que:

No âmbito dessas competências de logo avançadas pela Constituição é que se inscrevem, conforme visto, os poderes do inciso II, acima transcrito. Dispositivo que se compõe de mais de um núcleo normativo, quatro deles expressos e um implícito, que me parecem os seguintes: I núcleos expressos: a) "zelar pela observância do art. 37" (comando, esse, que, ao contrário do que se lê no inciso de n. I, não se atrela ao segundo por nenhum gerúndio); b) "apreciar, de ofício ou mediante provocação, a legalidade dos atos administrativos praticados por membros ou órgãos do Poder Judiciário"; c) “podendo desconstitui-los,”(agora, sim, existe um gerúndio), "revê-los ou fixar prazo para que se adotem as providências necessárias ao exato cumprimento da lei”; d) "sem prejuízo da competência do Tribunal de Contas da União" (isto quando se cuidar, naturalmente, da aplicação de lei em tema de fiscalização "contábil, financeira, orçamentária, operacional e patrimonial”, mais aquelas densificadoras dos princípio da"economicidade", "eficácia e eficiência" das respectivas gestões, pelo fato de que nesses espaços jurídicos é que também se dá a atuação dos Tribunais de Contas, tudo conforme os arts. 70 e 74 da Constituição Federal); II - o núcleo inexpresso é a outorga de competência para o Conselho dispor, primariamente, sobre cada qual dos quatro núcleos expressos, na lógica pressuposição de que a competência

\footnotetext{
${ }^{253}$ Trecho do voto do Ex-Ministro Ayres Britto, relator da ADC n. 12.
} 
para zelar pela observância do art. $37^{254}$ da Constituição e ainda baixar os atos de sanação de condutas eventualmente contrárias à legalidade é poder que traz consigo a dimensão da normatividade em abstrato, que já é uma forma de prevenir a irrupção de conflitos. O poder de precaver-se ou acautelar-se para minimizar a possibilidade das transgressões em concreto. ${ }^{255}$

Vale ainda a menção ao voto do Ministro Joaquim Barbosa, a apontar que, uma vez que o Conselho foi incumbido da função de assegurar a observância dos princípios constitucionais regentes da atuação administrativa do Poder Judiciário, é curial que se considere lícita a possibilidade de imposição, pelo Conselho, mediante ato normativo próprio, de obrigações nesse específico sentido.

José Adércio Leite Sampaio ${ }^{256}$ faz uma importante ressalva em relação aos limites do poder regulamentar do Conselho no sentido de que "não se pode aceitar que, de princípios abertos, se possam extrair vedações que não se encontrem positivadas em lei ou reconhecidas pela jurisprudência”.

Mais incisivas são as críticas trazidas por Lênio Streck, Ingo Sarlet e Clemerson Clève, que veem no poder de expedir atos regulamentares um "objetivo específico de controle externo", a partir de situações concretas que surjam no exercício das atividades do Judiciário - "aliás, não se pode esquecer que é exatamente o controle externo que se constituiu na ratio essendi da criação de ambos os Conselhos [de Justiça e do Ministério Público]". ${ }^{257}$

Para Streck, Sarlet e Clève, o fato de a Emenda Constitucional n. 45, de 2004, estabelecer o poder do Conselho de editar atos regulamentares não pode significar "uma carta branca para tais regulamentações". Afinal, existem duas limitações, segundo eles: uma, stricto sensu, "pela qual não podem expedir regulamentos com caráter geral e abstrato, em face da reserva de lei"; outra, lato sensu, "que diz respeito à impossibilidade de ingerência nos direitos e garantias fundamentais dos cidadãos".

\footnotetext{
${ }^{254}$ Vale também colacionar o entendimento de Gustavo Guerra (2010, p. 123), no que se refere especificamente ao que foi analisado na $\mathrm{ADC} 12$, no caso da resolução de vedação ao nepotismo, tal como foi defendido pela maioria do Supremo, "a razão está menos na competência regulamentar prevista no inciso I, $\S 4^{\circ}$, do art. 103-B e mais na sua combinação com o seguinte que atribui ao CNJ o dever de zelar pela observância do art. 37"

${ }^{255}$ Ementa do julgamento da ADC n. 12.

${ }^{256}$ Sampaio, 2007, p. 281.

${ }^{257}$ Streck, Sarlet e Clève, 2005, pp. 16-26.
} 
Ademais, para tais autores, "o poder regulamentar dos Conselhos esbarra impossibilidade de inovar"; tal poder não pode ser transformado em "poder de legislar", nem pode ser justificado pela própria Emenda Constitucional n. 45, de 2004, pois se este argumento estivesse correto, 'bastaria elaborar uma emenda constitucional para 'delegar' a qualquer órgão o poder de 'legislar' por regulamentos". E com isto, "restariam fragilizados inúmeros princípios que conformam o Estado Democrático de Direito". ${ }^{258}$ Detalhando a análise, arrematam que:

"O exercício do poder regulamentar do CNJ, previsto no inciso I, do art. 103-B, CF, não pode i) estabelecer novos direitos e deveres, ii) criar regras gerais e abstratas e iii) restringir direitos fundamentais. Por sua vez, esse poder regulamentar deveria concretizar leis formais (leis ordinárias e complementares) já estabelecidas e excepcionalmente efetivar diretamente a constituição. Esse poder regulamentar possui uma função parecida com as leis medidas, devendo o CNJ exercer esse poder no âmbito de sua competência (atuações financeiras e orçamentárias, cumprimento dos deveres judiciais e outras competências postas na constituição e no Estatuto da Magistratura). Concorda-se que há uma diferença estrutural e política entre as leis ordinárias e complementares, de um lado, e o poder regulamentar do CNJ, de outro lado. Os limites do poder regulamentar do $\mathrm{CNJ}$ dependem de duas questões: i) novo Estatuto da Magistratura Nacional e ii) costumes constitucionais firmados pelo CNJ, Supremo Tribunal Federal, Congresso Nacional e Presidente da República". 259

Apesar dos sérios argumentos trazidos por esta abalizada doutrina, o entendimento que prevaleceu no Supremo Tribunal Federal, em especial quando do julgamento da Ação Declaratória de Constitucionalidade n. 12 - o qual se considera bastante apropriado - foi o de que o Conselho Nacional de Justiça é dotado de poder normativo no âmbito de suas competências e atribuições.

\footnotetext{
${ }^{258}$ Streck, Sarlet e Clève, 2005, pp. 16-26.

${ }^{259}$ Robl Filho, 2012, pp. 244-245.
} 


\section{CAPÍTULO IV}

\section{A COMPETÊNCIA DISCIPLINAR DO \\ CONSELHO NACIONAL DE JUSTIÇA}

“O Sr. Ministro NELSON JOBIM (Presidente)

- A observação, Ministro, é de que a correição

horizontal é quase inexistente; a vertical, pode

dar exemplos, os quais são estatísticos.

O Sr. Ministro CARLOS VELLOSO - Quer

dizer, Ministro Carlos Britto, que Vossa

Excelência acaba entendendo que essas

questões devem ser examinadas pelo

Conselho?

O Sr. Ministro CARLOS BRITTO -

Concorrentemente, como, aliás, diz a Emenda.

O Sr. Ministro CARLOS VELLOSO - Aliás, é

o que escrevi em 1986. Penso assim também.

Em 1986, cheguei a dizer isso, falando até que

somos capazes de punir os juizes

tardinheiros ". 260

${ }^{260}$ Trecho dos debates que ocorreram durante o voto do Ex-Ministro Carlos Velloso, no julgamento da Ação
Direta de Inconstitucionalidade n. 3367 , pelo Supremo Tribunal Federal, acerca da possibilidade de o
Conselho Nacional de Justiça exercer controle sobre infrações administrativas cometidas por magistrados de
segunda instância. Sem destaques no original. Ainda relativamente ao julgamento desta ação direta, vale um
registro de uma análise da competência disciplinar do Conselho Nacional de Justiça, feita pelo ex-Ministro
Carlos Velloso. Afirmou ele que tal competência, de todas as atribuições do órgão, é "certamente a mais
complexa"; justificou esta sua afirmação apontando que o "gigantismo do Judiciário brasileiro poderia gerar
um grande número de representações". Com isso, alertou o ex-Ministro, "se não for criada uma estrutura
moderna e eficiente, o Conselho corre o risco de cair no descrédito, de cair no ridículo", impactando,
inclusive, nos trabalhos do próprio Supremo Tribunal Federal - "as prebendas vão avolumar-se nesta Casa". 


\section{IV.1. Considerações Iniciais}

Nos capítulos anteriores, objetivando construir um pano de fundo para o estudo específico da competência disciplinar do Conselho Nacional de Justiça, foram analisados (i) a contextualização de sua criação, (ii) os principais aspectos de sua estrutura e funcionamento e (iii) o entendimento jurisprudencial, segundo o Supremo Tribunal Federal, acerca da constitucionalidade da sua criação.

Neste capítulo, após algumas considerações gerais sobre a definição de competência e sua relação com a temática dos controles da Administração e com a doutrina dos poderes administrativos, será realizada uma análise da relação da competência disciplinar do Conselho com os princípios de independência e de responsabilização do Poder Judiciário, com a noção de accountability e com o princípio da publicidade.

Em seguida, a competência disciplinar do Conselho Nacional de Justiça será estudada, com o objetivo de caracterizá-la, relativamente às atribuições das Corregedorias dos Tribunais em geral, como sendo de natureza concorrente ou, por outro lado, de caráter subsidiário.

IV.2 Aspectos gerais relativos à competência: definição de competência e relação com a temática dos controles da Administração Pública e com a doutrina dos poderes administrativos

Em definição dada por Ruy Cirne Lima, a doutrina da competência no Direito Administrativo é formada pelo "estudo dos poderes de direito público conferido às pessoas administrativas". E, em sentido lato, "competência se denomina, em direito público, a medida do poder que a ordem jurídica confere a uma determinada pessoa". ${ }^{261}$

Apenas a título comparativo, é interessante registrar o entendimento de Cândido Rangel Dinamarco que, no âmbito do Direito Processual, define competência como sendo o "conjunto das atribuições jurisdicionais de cada órgão ou grupo de órgãos, estabelecidos pela Constituição e pela lei”. Neste sentido processual, a competência é

${ }^{261}$ Cirne Lima, 2007, p. 385. 
tradicionalmente conceituada como medida da jurisdição ou quantidade de jurisdição cujo exercício é atribuído a um órgão ou grupo de órgãos. ${ }^{262}$ Em outras palavras, considerando determinado órgão judiciário, ou grupo de órgãos, sua competência é representada pela "massa de atividades jurisdicionais que a ele cabe realizar, segundo o direito positivo". ${ }^{263}$

Voltando a analisar o conceito de competência sob a perspectiva do Direito do Estado, para Celso Antônio Bandeira de Mello, competência pode ser conceituada como o "círculo compreensivo de um plexo de deveres públicos a serem satisfeitos mediante o exercício de correlatos e demarcados poderes instrumentais, legalmente conferidos para a satisfação de interesses públicos". ${ }^{264}$

Aprofundando a análise deste conceito, deve-se atentar para a presença de dois elementos importantes: a estreita relação entre competência e poderes administrativos, e a finalidade de atendimento dos interesses públicos.

Com efeito, Bandeira de Mello ressalta que, "antes que poderes efetivamente seu lado mais aparente -, as competências são deveres, o que é particularmente visível no caso das competências administrativas". Na verdade, "elas são poderes-deveres, expressão esta que começou a ser utilizada no Direito Administrativo a partir das lições de Santi-Romano". ${ }^{265}$

Dessa forma, "o poder expressado nas competências não é senão a face do dever de bem satisfazer interesses públicos". Afinal, tais "competências são atribuídas ao Estado, a seus órgãos, e, pois, aos agentes neles investidos, especificamente para que possam atender a certas finalidades públicas consagradas em lei". 266

E, acrescenta Bandeira de Mello, que em razão de a atividade administrativa submeter-se à lei e preordenar-se à satisfação de seus comandos, as competências administrativas nada mais podem ser "senão feixes de atribuições concebidas para proporcionar a realização in concreto dos desideratos legais, cujo atendimento propõe-se para órgãos e agentes administrativo como uma imposição à qual, de direito, não podem se esquivar". Por este motivo, “os poderes nela contidos, por definição, ficarão delimitados

\footnotetext{
${ }^{262}$ Trata-se de célebre definição dada por Enrico Tulio Liebman.

${ }^{263}$ Dinamarco, 2009, p. 410.

${ }^{264}$ Bandeira de Mello, 2004, p. 132.

${ }^{265}$ Bandeira de Mello, 2004, pp. 132-133.

${ }^{266}$ Bandeira de Mello, 2004, pp. 133-134.
} 
pelo necessário e suficiente ao cumprimento do escopo normativo, jamais podendo excedêlos". 267

Consequentemente, não obstante "apareçam abstratamente com a extensão, intensidade e amplitude necessárias para colher várias hipóteses possíveis", as competências outorgam, concretamente, "única e exclusivamente o quantum de poder indispensável para curar o interesse em vista do qual foram atribuídas a alguém, ou seja, nada mais do que o requerido para a satisfação do dever que lhes preside a existência". ${ }^{268}$

Por todos estes motivos é que as competências são (i) de exercício obrigatório para os órgãos e agentes públicos; (ii) irrenunciáveis - seu titular não pode delas se desfazer enquanto as titularizar; (iii) intransferíveis - cabendo, tão-somente, nos casos previstos em lei, delegação de seu exercício; (iv) imodificáveis pela própria vontade do titular; e (v) imprescritíveis. ${ }^{269}$

Delimitando o objeto de estudo, o tema da competência disciplinar do Conselho Nacional de Justiça, de natureza eminentemente constitucional, também possui uma estreita relação com algumas questões muito caras ao Direito Administrativo, como, por exemplo, a temática dos controles da Administração Pública e, como não poderia deixar de ser - pelo que foi exposto acima - a doutrina dos poderes administrativos.

Com efeito, algumas das atividades desempenhadas pelo Conselho Nacional Justiça estão claramente estampadas no conceito de controle da Administração Pública formulado por Diógenes Gasparini - "atribuição de vigilância, orientação e correção de certo órgão ou agente público sobre a atuação de outro ${ }^{270}$ ou de sua própria atuação ${ }^{271}$, objetivando confirmá-la ou desfazê-la, conforme seja, ou não, legal, conveniente, oportuna e eficiente" ${ }^{, 272}$.

É relevante destacar que a existência de controles inseridos nos processos de poder, os chamados "controles institucionalizados", desempenha importante função em um Estado Democrático de Direito, e possui destacada importância no combate à corrupção. ${ }^{273}$

\footnotetext{
${ }^{267}$ Bandeira de Mello, 2004, p. 134.

${ }^{268}$ Bandeira de Mello, 2004, pp. 134-135.

${ }^{269}$ Bandeira de Mello, 2004, p. 135.

${ }^{270}$ Controle externo ou heterocontrole.

${ }^{271}$ Controle interno ou autocontrole.

272 Gasparini, 1995, p. 532.

${ }^{273}$ Nesse sentido, Medauar, 2005, p. 441. Sobre o tema do controle da atividade estatal e da natureza administrativa do controle exercido pelos Conselhos Nacionais de Justiça e do Ministério Público, cf. Slaibi Filho, 2005, pp. 282-283.
} 
Segundo Diógenes Gasparini, a competência disciplinar - por ele denominada atribuição disciplinar - é a que se reconhece em favor da Administração Pública, no exercício de seu poder disciplinar, para punir ${ }^{274}$ seus servidores pelo cometimento de infrações funcionais. Seu fundamento reside "na supremacia especial que a Administração Pública exerce sobre as pessoas que a ela se ligam por relações jurídicas específicas, como a estatutária”. E, na mesma linha do que é defendido por Bandeira de Mello, trata-se de "verdadeiro dever-poder da Administração Pública". ${ }^{275}$

Ainda de acordo com Gasparini ${ }^{276}$, está na necessidade de se instrumentar a Administração Pública para o "cumprimento de sua razão de ser, o porquê dos poderes que lhe são conferidos. Nesse mesmo sentido, José Cretella Junior pondera que o poder disciplinar tem sua origem e razão de ser no interesse e na necessidade de aperfeiçoamento progressivo do serviço público. ${ }^{277}$

Odete Medauar, por sua vez, afirma que o poder disciplinar é atribuído à autoridade administrativa "com o objetivo de apurar e punir faltas funcionais, condutas contrárias à realização normal das atividades do órgão, irregularidades de diversos tipos". E acrescenta que "tal poder se materializa por meio de atividade administrativa, regida pelo direito administrativo, segunda normas do processo administrativo" e tem por objetivo a "punição de condutas, qualificadas em estatutos ou em outros instrumentos normativos, como infrações funcionais". Sua finalidade é "preservar, de modo imediato, a ordem interna do serviço, para que as atividades do órgão possam ser realizadas sem perturbação e sem desvirtuamentos, dentro da legalidade e da lisura". 278

Feitas estas apresentações, antes de se passar à análise relação da competência disciplinar com a independência e a responsabilização do Poder Judiciário, cabe um último registro, também consignado por Odete Medauar: as normas que regem o poder disciplinar, que decorrem da Constituição da República, dos Estatutos dos servidores, das leis orgânicas de categorias profissionais, dos princípios do direito

\footnotetext{
${ }^{274}$ As penas aplicáveis, variáveis de acordo com a legislação aplicável, são, por exemplo, repreensão, multa, suspensão, destituição de função, demissão, cassação de aposentadoria ou disponibilidade.

${ }^{275}$ Gasparini, 1995, pp. 171-172.

${ }^{276}$ Gasparini, 1995, p. 53.

${ }^{277}$ Cretella Junior, 1966-1974, p. 163.

${ }^{278}$ Medauar, 2005, pp. 353-354.
} 
administrativo, da jurisprudência - esta com "influência marcante na matéria" -, informam o chamado regime disciplinar. ${ }^{279}$

\section{IV.3. Competência disciplinar do Conselho Nacional de Justiça entre Independência e Responsabilização do Poder Judiciário}

A independência de cada um dos Poderes, no Estado de Direito contemporâneo, pressupõe, necessariamente, formas de controle e responsabilidade. No âmbito do Poder Judiciário, deve-se buscar a instituição de mecanismos eficientes de fiscalização que zelem pelo regular exercício de suas atividades, sem interferir nem adentrar no mérito da prestação jurisdicional em si mesma. ${ }^{280}$

De acordo com Pontes de Miranda, a formulação dos princípios da independência dos juízes e da subordinação dos juízes ao direito deve ser o primeiro cuidado do legislador constitucional, ao tratar do Poder Judiciário. ${ }^{281}$

Foi justamente um equilíbrio entre os princípios da independência e responsabilização dos membros do Poder Judiciário que a Emenda Constitucional n. 45/2004 procurou contemplar.

A discussão sobre a independência da Magistratura aparece frequentemente ligada aos temas da liberdade, da justiça social e da democracia. Isso faz pressupor a existência de um papel político da Magistratura e enseja uma importante reflexão sobre sua independência, sobre razões pelas quais se deseja que ela seja independente e com que objetivos ela deve utilizar a independência que lhe for assegurada. ${ }^{282}$

\footnotetext{
${ }^{279}$ Medauar, 2005, p. 354. Odete Medauar acrescenta que os aspectos fundamentais do regime disciplinar aplicam-se a outros âmbitos, na ausência de disposições específicas explícitas, tal como, por exemplo, no exercício do poder disciplinar do Judiciário sobre seus magistrados.

${ }^{280}$ Jobim, 2012, sem paginação.

${ }^{281}$ Pontes de Miranda, 1970, p. 552.

${ }^{282}$ Neste ponto, Dallari (2008, p. 49) acrescenta que devem ser sempre lembradas circunstâncias sociais e políticas que caracterizam este momento da história brasileira e latino-americana em especial, porque nesse contexto existem peculiaridades de extrema importância, que devem ser consideradas no exame da exigência de independência da magistratura e das dificuldades que aí estão implicadas.
} 
Nesse sentido, Dalmo Dallari aponta algumas justificativas para a necessidade de se assegurar a independência do Poder Judiciário. ${ }^{283}$

A primeira delas ${ }^{284}$ está no fato de que um Judiciário independente é o que pode garantir a eficácia das regras de comportamento social inspiradas na busca do ideal de justiça. O Judiciário deve ser independente também para que se possa orientar no sentido da justiça, decidindo com equidade os conflitos de interesses. A independência do Judiciário é necessária, além disso, para garantir a possibilidade de novas conquistas sociais, para a eliminação das injustiças existentes e para que os avanços no sentido da justiça sejam consolidados. Assim, a independência do Poder Judiciário é entendida como um valor instrumental ${ }^{285}$. Por todos esses motivos, deve ser dado todo o apoio para que o Judiciário possa conquistar e manter sua independência, que deve concreta e bem protegida dos efeitos de eventuais oscilações políticas. ${ }^{286}$

Algumas medidas devem ser adotadas para que se tenha e mantenha a um Judiciário independente. ${ }^{287}$

Em primeiro lugar, deve-se procurar conhecer a realidade deste Poder e, quando for o caso, "reconhecer honesta e serenamente suas eventuais falhas de organização e funcionamento". Além disso, deve-se fazer, "sem rodeios e sem disfarces, a afirmação da natureza política do problema da independência da Poder Judiciário", pois “o tratamento desse assunto como questão de natureza exclusivamente técnica tem facilitado a negativa ou adiamento da superação de falhas fundamentais". Além do mais, importa realizar uma "discussão constante e franca", para a definição e adoção dos "meios concretos para a mudança estrutural da sociedade e do Estado, no sentido de garantir uma prática democrática”. Finalmente, é necessário que “os juízes queiram ${ }^{288}$ ser independentes e trabalhem para isso". 289

Segundo Eugênio Raúl Zaffaroni a independência judicial pode ser desmembrada em independência da Magistratura e independência pessoal do juiz. A

\footnotetext{
${ }^{283}$ Dallari, p. 47.

${ }^{284}$ De inspiração nos teóricos liberais-racionalistas do século XVIII.

${ }^{285}$ Cappelletti, 1989, p. 32.

${ }^{286}$ Dallari, 2008 , p. $47-49$ e p. 55.

${ }^{287}$ Dallari, 2008, p. 55-61.

${ }^{288}$ Dalmo Dallari (2008, p. 60) adverte que, "na realidade, as transigências frequentes, a renúncia aos seus valores próprios, a tolerância com a violência e a arbitrariedade, a aceitação das 'razões de Estado', a adoção de teses que implicam a negação de convicções solenemente proclamadas, tudo isso, que tem estado presente no comportamento da magistratura como instituição, permite a suposição de que, na realidade, a magistratura não quer ser independente".

${ }^{289}$ Dallari, 2008, p. 55-61.
} 
independência da Magistratura é condição para a existência da independência do juiz, e implica a autonomia de governo do Poder Judiciário, bem como o a existência do poder disciplinar. A independência do juiz, por outro lado, é a que importa a garantia de que o juiz não sofrerá as pressões dos órgãos colegiados do próprio Judiciário. ${ }^{290}$

Para Luiz Flávio Gomes, a independência pessoal do juiz pode ser dividida em interna e externa.

A independência pessoal externa do juiz - chamada independência política - objetiva protegê-lo das ingerências e pressões que possam vir de fora da instituição (ad extra). As tradicionais garantias e proibições constitucionais vinculadas ao juiz vitaliciedade, irredutibilidade de vencimentos, proibição de filiação partidária - nada mais representam do que a materialização desta independência. ${ }^{291}$

Já a independência interna do juiz - que configura sua independência funcional - visa a resguardá-lo dentro (ad intra) da sua própria instituição frente aos demais órgãos jurisdicionais, principalmente aos colegiados, bem como frente aos seus órgãos de governo. ${ }^{292}$

Zaffaroni considera que ambas as formas de independência do juiz - a externa e a interna - são igualmente necessárias para possibilitar sua independência moral, ou seja, para dotá-lo do espaço de decisão necessário a que resolva conforme seu entendimento do direito. ${ }^{293}$

De acordo com Luigi Ferrajoli, "a independência da função judiciária” deve ser assegurada tanto à Magistratura enquanto classe - nas relações com outros Poderes, "em particular o Poder Executivo" - como ao magistrado enquanto indivíduo - nas relações hierárquicas internas à classe, as quais de algum modo possam influenciar a autonomia de julgamento. ${ }^{294}$

Para José Adércio Leite Sampaio, acompanhado por Hamilton Schwartz, a independência do Judiciário tem dois aspectos: um de caráter institucional, orgânico e

\footnotetext{
${ }^{290}$ Zaffaroni, 1995, p. 88.

291 Gomes, 1993, p. 66. Luiz Flávio Gomes ressalta que várias outras garantias, não positivadas constitucionalmente de forma expressa, como por exemplo a necessidade de proteção e segurança de sua vida e de sua liberdade individual, principalmente quando e onde existem situações concretas de ameaça, também são fundamentais para o exercício livre da jurisdição e talvez merecessem previsão constitucional.

${ }^{292}$ Gomes, 1993, p. 18.

293 Zaffaroni, 1995, p. 90.

${ }^{294}$ Ferrajoli, 2010, p. 538. Destaque-se um outro autor italiano a estudar a independência do Judiciário Gustapane, 1999.
} 
externo ou coletivo; outro de natureza subjetiva, particular e interna. A independência externa concerne à autonomia do Judiciário como Poder, em face das forças exteriores, sejam elas os outros Poderes, os partidos políticos, a imprensa e mesmo a sociedade civil organizada. Engloba o autogoverno judiciário e a independência do Juiz. A independência interna é a que diz respeito ao juiz em relação a seus pares (de mesmo nível ou superior), e as entidades ou outros órgãos do próprio Poder. Está a se proteger a independência da decisão. ${ }^{295}$

Um interessante destaque feito por Zaffaroni, é no sentido de que a pressão sofrida pelos juízes em face da lesão à sua independência externa, em um país democrático, é relativamente neutralizável, por via da liberdade de informação, de expressão e de crítica; a lesão de sua independência interna, por outro lado, é muito mais contínua, sutil, humanamente deteriorante e eticamente degradante. ${ }^{296}$

Quanto menor seja o espaço de poder da Magistratura, vale dizer, quanto menor independência externa possua, maior parece ser a compensação buscada pelos seus corpos colegiados no "exercício tirânico de seu poder interno". A independência interna somente pode ser garantida dentro de uma estrutura judiciária que reconheça igual dignidade a todos os juízes.

O juiz não pode sofrer qualquer espécie de violência, de ameaça ou de constrangimento material, moral ou psicológico. Ele necessita da independência para poder desempenhar plenamente suas funções, decidindo com serenidade e imparcialidade, cumprindo verdadeira missão no interesse da sociedade. ${ }^{297}$

Estas considerações e a necessidade da independência, como pressuposto ou condição indispensável da imparcialidade, que é caráter essencial da jurisdição ou jurisdicionariedade, bastam para comprovar que ela não deriva da separação tripartida de poderes, que é uma exceção dentro do Estado - cujas funções se caracterizam pela independência - e que, ao definir-se ou demandar-se em razão da essência da mesma atividade jurisdicional, deve-se reconhecer que este mesmo conceito erradica qualquer pretensão de independência absoluta do juiz com o sistema. ${ }^{298}$

\footnotetext{
${ }^{295}$ Sampaio, 2007, p. 129; 140-141 e Schwartz, 2009.

${ }^{296}$ Zaffaroni, 1995, p. 89.

${ }^{297}$ Dallari, 2008, p. 47-49.

${ }^{298}$ Zaffaroni, 1995, p. 90.
} 
O requisito da imparcialidade, por sua vez, decompõe-se em três perfis equidistância, independência e naturalidade. A equidistância corresponde ao afastamento, pelo juiz, dos interesses das partes demandantes. A independência refere-se à exterioridade do Juiz ao sistema político em geral e a todo sistema de poderes. Por fim, a naturalidade relaciona-se com a predeterminação exclusivamente legal das competências jurisdicionais. $^{299}$

Sobre a independência dos juízes e a politização do judiciário, Zaffaroni discorre que, "em princípio, os poderes judiciários não podem deixar de estarem politizados no sentido de quem cumprem funções políticas”. A isso, acresce que é importante que se faça uma clara distinção: por um lado, "quanto mais consciente seja um Poder Judiciário acerca de seu papel político, mais idôneo será para cumpri-lo e assim, desempenhar suas funções, que são sempre políticas"; por outro lado, "quanto mais partidário ou parcializado, menos jurisdicional será". De acordo com esse entendimento, “a partidarização nada mais é do que o cancelamento da dimensão democrática da estrutura judiciária, supressora do pluralismo". ${ }^{300}$

A independência do Juiz em relação aos outros Poderes está ligada, de um lado, ao princípio da estrita legalidade e à natureza cognitiva de jurisdição e, de outro lado, aos direitos fundamentais. Os fundamentos externos ou políticos da independência judicial são os mesmo que legitimam a jurisdição: busca da verdade e tutela das liberdades ${ }^{301}$.

Como corolário de sua independência, reserva-se, constitucionalmente, ao Poder Judiciário, o poder exclusivo de apresentar ao Poder Legislativo projetos de lei sobre matérias relacionadas a seu autogoverno.

Feliciano e Dantas entendem que se mostra atentatória à independência dos Magistratura a instauração de qualquer modalidade de procedimento administrativo - em especial os de natureza disciplinar e as sindicâncias que os precedem - nos casos ou situações em que a atuação do magistrado se pauta em entendimento jurídico devidamente exposto e fundamentado. ${ }^{302}$ Isso porque a garantia da segurança jurídica, nos Estados Democráticos de Direito, é dada pela fundamentação da decisão judicial ${ }^{303}$, não pelo

\footnotetext{
${ }^{299}$ Ferrajoli, 2010, p. 534.

${ }^{300}$ Zaffaroni, 1995, p. 94-96.

${ }^{301}$ Ferrajoli, 2010, p. 538.

${ }^{302}$ Feliciano e Dantas, 2011, sem paginação.

${ }^{303}$ De acordo com o art. 93, IX, da Constituição da República.
} 
engessamento da atividade judicante segundo parâmetros de constitucionalidade, legalidade e justiça ditados por órgãos judiciários de cúpula. ${ }^{304}$

Por esta razão, não se pode relativizar a garantia de independência de entendimento dos magistrados, ainda que desagrade a parte e seja contrária ao entendimento majoritário da doutrina, jurisprudência ou, ainda, dos órgãos imbuídos do poder disciplinar. Afinal, para rever e questionar decisões judiciais fundamentadas há meios e recursos processuais próprios, não sendo aceitável o uso transverso da via disciplinar. Também não se mostra aceitável a utilização da via correcional ou disciplinar com o propósito de atingir a honra, a dignidade e o decoro do magistrado simplesmente por discordar do mérito de seus atos judiciais. ${ }^{305}$

É interessante o destaque de Ferrajoli no sentido de que a independência judicial é "um fato cultural antes que institucional" e que, por esta razão, a "autonomia da magistratura como poder independente amadurece pro meio de um lento processo, trabalhoso e não inconteste". 306

Antes de se passar à análise da questão da responsabilização judicial, cabe o registro do entendimento de Fernanda Flurh ${ }^{307}$, no sentido de que é possível perceber a

304 Feliciano e Dantas (2011, sem paginação) corretamente excepcionam os casos constitucionalmente previstos: a jurisdição constitucional de tipo concentrado, que surte efeitos vinculantes "erga omnes", e, após o advento da EC n. 45/2004, as súmulas vinculantes do Supremo Tribunal Federal.

${ }^{305}$ Feliciano e Dantas, 2011, sem paginação.

${ }^{306}$ Ferrajoli, 2010, p. 542.

307 Flurh (2011, pp. 73-74) entrevê na atuação do Conselho Nacional de Justiça uma considerável possibilidade de intervenção na autonomia e na independência do Poder Judiciário. Para tanto, cita caso noticiado na imprensa nacional sobre a intervenção do Conselho em decisão proferida por uma Juíza do Estado do Pará. No caso, a corregedora nacional de Justiça cancelou, liminarmente, uma decisão da juíza que bloqueou dinheiro de uma instituição bancária, além de converter, de ofício, o pedido de providência, formulado pelo banco em desfavor da magistrada, em Reclamação Disciplinar. Tal ato do Conselho Nacional de Justiça foi objeto de Reclamação proposta perante o Supremo Tribunal Federal pela Associação de Magistrados Brasileiros, em defesa das prerrogativas da magistratura e da fixação dos limites da competência do CNJ. A Reclamação dantes referida ainda encontra-se pendente de julgamento e tramita em segredo de justiça. Ainda segundo Flurh, outro exemplo citado de interferência do Conselho Nacional de Justiça na autonomia do Judiciário pode ser vislumbrado no Mandado de Segurança n. 28.286, impetrado no Supremo Tribunal Federal pela Associação dos Magistrados Paulistas, em face de decisão do CNJ, nos autos do Pedido de Providências n. 2007.2010.00001131-0, proposto pelo Tribunal de Justiça do Distrito Federal, que negou o direito aos magistrados de receber indenização por férias não gozadas. Neste caso, o Conselho Nacional de Justiça sustentou o interesse da Administração da Justiça em sua decisão, alegando que as férias justificam-se pela necessidade fisiológica e psicológica de um período prolongado de repouso para os exercentes de atividade contínua e que, neste contexto, as férias dos magistrados atendem tanto ao interesse individual quanto ao interesse da Administração da Justiça e à própria sociedade que necessitam de agentes públicos em pleno gozo de saúde física e mental para o satisfatório desempenho das atividades jurisdicionais. Por tal razão, justificou dizendo que a regra legal proibitiva de acúmulo de mais de dois períodos de férias dos magistrados volta-se à direção dos tribunais que haverá de assegurar a fruição periódica e sem retardamento dos períodos de férias adquiridos. Sobre a questão da conversão em pecúnia do direito às férias, disse que, desde que caracterizada a absoluta impossibilidade material de fruição exclusivamente por necessidade imperiosa de continuidade da prestação dos serviços jurisdicionais e havendo disponibilidade financeira e 
existência de potencial conflito entre as atribuições do Conselho Nacional de Justiça e a preservação da independência e autonomia do Poder Judiciário.

No mesmo sentido, o Ministro Marco Aurélio, na votação da Ação Direta de Inconstitucionalidade n. 3367, advertiu sobre a inevitável repercussão - na visão dele - da competência disciplinar do Conselho Nacional de Justiça no ofício judicante:

\begin{abstract}
"Vem-nos do $\S 4^{\circ}$, inciso I, que a ele [Conselho Nacional de Justiça] incumbe 'zelar pela autonomia do Poder Judiciário'. A autonomia do Poder Judiciário não será fruto da existência de um órgão que atue ao lado do próprio Poder Judiciário, exercendo influência implícita nesse Poder, já que não podemos ser ingênuos a ponto de acreditar que a atividade a ser desenvolvida pelo Conselho Nacional de Justiça não repercutirá no ofício judicante, exercido por seres humanos, e circunstâncias externas acabam por repercutir na formalização de decisões."
\end{abstract}

De acordo com o alerta feito por Dieter Grimm, "a garantia constitucional de independência judicial protege os juízes da política, mas não protege o sistema constitucional e a sociedade de juízes que, por razões distintas da pressão política direta, estão dispostos a desobedecer ou distorcer a lei". ${ }^{308}$

Com efeito, o contraponto da independência judicial é dado pela necessidade de responsabilização do Poder Judiciário, enquanto instituição como um todo, e também no que diz respeito aos seus membros individualmente considerados.

orçamentária, é regular a indenização pecuniária, em caráter excepcionalíssimo, das férias dos magistrados que não puderem ser fruídas até o momento em que, por qualquer razão, deixe de pertencer ao quadro de magistrados ativos. Sustentou ainda que abusos na conversão pecuniária das férias de magistrados sujeitam as autoridades ordenadoras das respectivas despesas à responsabilidade civil, administrativa e penal, conforme o caso, conhecendo assim da Consulta efetuada pelo Tribunal de Justiça do Distrito Federal e respondendo, quanto à primeira indagação, negativamente e, em termos, favoravelmente às demais indagações formuladas. Em sede de Mandado de Segurança impetrado pela Associação dos Magistrados Paulistas junto ao Supremo Tribunal Federal, o Ministro Relator Marco Aurélio deferiu a liminar pleiteada, afastando a eficácia do ato do Conselho Nacional de Justiça impugnado, assegurando aos substituídos da Associação impetrante o gozo das férias uma vez completado o período aquisitivo e, na impossibilidade de atender-se a esse direito constitucional, por imperiosa necessidade do serviço certificada ante o requerimento do magistrado, a indenização simples de período de férias que ultrapasse os sessenta dias, a ser satisfeita, mediante opção do interessado, conforme a disponibilidade orçamentária.

${ }^{308}$ Dieter Grimm, citado por Guerra, 2010, pp. 75-76. 
A Declaração dos Direitos do Homem e do Cidadão, de 1789, já continha, em seu artigo 15, o preceito segundo o qual "a sociedade tem o direito de pedir contas, a todo agente público, quanto à sua administração". 309

A responsabilidade judicial pode significar "tanto o poder dos juízes, quanto o seu dever de prestação de contas no exercício de tal poder-responsabilidade”. Há uma conexão entre as duas acepções da responsabilidade judicial - a responsabilidade como poder-função e a responsabilidade como dever de prestar contas. Em outras palavras, os juízes exercitam um poder; e, onde há poder deve haver responsabilidade. Por esta razão, pode-se dizer que "o problema da responsabilidade judicial torna-se mais ou menos importante conforme o maior ou menor poder dos juízes em questão. ${ }^{310}$

Trata-se de um poder que é ao mesmo tempo um dever - o dever do juiz de exercer a função pública de julgar. E porque o exercício de tal função é disciplinado por regras e princípios, escritos ou não-escritos, a óbvia consequência será uma responsabilidade no sentido ulterior de sujeição a sanções daqueles que, em tal exercício, violem essas regras ou princípios. ${ }^{311}$

Mauro Cappelletti traz uma importante tipologia da responsabilidade judicial. Um primeiro tipo é a responsabilidade política, seja do juiz individualmente, seja da Magistratura ${ }^{312}$; tal responsabilidade subdivide-se em responsabilidade em face dos poderes políticos e responsabilidade constitucional. Além dela, existe a responsabilidade social, que se dá perante o público em geral. Também este segundo tipo pode referir-se tanto ao juiz como indivíduo, quanto à Magistratura. Há também a responsabilidade jurídica (pessoal) do juiz, que pode ser civil, disciplinar ou penal. Finalmente, existe uma responsabilidade jurídica do Estado, que pode ser exclusiva, ou concorrente com a responsabilidade pessoal do juiz ${ }^{313}$

Concentrando-se especificamente na responsabilidade mais diretamente ligada ao objeto da presente dissertação - a responsabilidade disciplinar - cumpre realizar

\footnotetext{
${ }^{309}$ Nesse sentido, Medauar, 2005, p. 440.

${ }^{310}$ Cappelleti, 1989, pp. 17-18, que neste ponto é acompanhado por, dente outros, Guerra, 2010, p. 84: "propõe ao termo responsabilidade judicial núcleos de significação: é ao mesmo tempo, o poder dos juízes e, em contrapartida, o dever de prestar contas (accountability, answerability) no exercício de tal mister, caracterizando assim um "poder -responsabilidade".

${ }^{311}$ Cappelletti, 1989, p. 17.

${ }^{312}$ Entendida como conjunto de juízes de um país, tal como delineado na Introdução.

${ }^{313}$ Cappelletti, 1989, p. 36.
} 
alguns apontamentos a partir da diferenciação feita por Mauro Cappelletti entre responsabilidade civil, de um lado, e responsabilidade disciplinar, de outro.

Enquanto a responsabilidade civil é caracterizada por um "núcleo essencialmente privatístico" - pois sua finalidade primária consiste no ressarcimento do dano causado a um ou mais indivíduos pelo comportamento lesivo do juiz -, caracteriza a responsabilidade disciplinar um "núcleo essencialmente publicístico" - porque sua finalidade precípua consiste em "assegurar ${ }^{314}$ que os juízes observem os deveres do seu ofício - deveres tipicamente de direito público perante o Estado e a sociedade em geral". ${ }^{315}$

Prosseguindo com a distinção, pode-se dizer que, o objetivo primário da responsabilidade civil, ainda que dela decorra um benefício público indireto, é constranger magistrado culpado por seu comportamento lesivo a reparar um dano específico, causado ao jurisdicionado. Por outro lado, o objetivo fundamental da responsabilidade disciplinar é salvaguardar a honestidade e competência profissional, assegurando que os cidadãos podem, com confiança, dirigir-se ao Judiciário. Dessa forma, "a responsabilidade civil dirige-se ao passado" na medida em que "pretende punir atos lesivos específicos". A responsabilidade disciplinar, por sua vez, "dirige-se principalmente ao futuro", pois almeja "prevenir atos lesivos por desonestidade ou incompetência profissional". 316

A importância desta diferenciação está no fato de que esta característica da responsabilidade disciplinar - "de olhar sobretudo para o futuro" - deve repercutir na caracterização do procedimento disciplinar, cujo intento deve ser não somente o de descobrir se o juiz "fez algo", mas, sobretudo, de analisar se ele "está em condições de trabalhar como juiz".317

A partir desta tipologia da responsabilidade judicial, Cappelletti apresenta uma classificação tripartite dos modelos de estruturação do Poder Judiciário: "modelo da sujeição" - repressivo, "modelo do isolamento" - autônomo-corporativo, e "modelo da responsabilização social" - em função dos consumidores. ${ }^{318}$

\footnotetext{
${ }^{314}$ Por meio, segundo Cappelletti (1989, p. 71), de uma variedade de sanções disciplinares, como censura, perda da antiguidade, da remuneração, transferência ou aposentadoria forçada, remoção etc.

${ }^{315}$ Cappelletti, 1989, p. 71.

${ }^{316}$ Cappelletti, 1989, p. 72.

${ }^{317}$ Cappelletti, 1989, p. 72, que acrescenta: "esta diversa orientação dos dois processos, o da responsabilidade civil e o da responsabilidade disciplinar, deve resolver-se em standards diversos em matéria de prova, de diligência, e obviamente de sanções."

${ }^{318}$ Cappelletti, 1989, pp. 80 ss. Nesse sentido, ver também Jobim, 2012, sem paginação.
} 
A responsabilidade típica do modelo repressivo possui natureza política, encontrando-se a Magistratura obrigada a prestar contas aos poderes políticos, especialmente o Executivo. Neste modelo, pode-se verificar certa inoperabilidade - em virtude de dificuldades de ordem procedimental - e opressão dos membros da Magistratura. ${ }^{319}$

O modelo autônomo-corporativo é diametralmente oposto ao anterior. Segundo seus parâmetros, o Judiciário atua como um corpo independente, alheio à sociedade e ao restante da organização estatal ${ }^{320}$. Neste modelo, não só a instituição, mas cada membro individual do Poder Judiciário ganha grande autonomia, ficando ao largo de controles de qualquer natureza; por esta razão, sobre ele paira a ameaça da anarquia individual. $^{321}$

Finalmente, o modelo da responsabilização social procura combinar razoável medida de responsabilidade política e social, com razoável medida de responsabilidade jurídica, em seus subtipos principais - civil, disciplinar e penal. Busca, com isso, de um lado, evitar "a subordinação dos juízes aos poderes políticos, aos partidos políticos e a outras organizações sociais", bem como evitar "ações vexatórias de litigantes irritados". Objetiva, de outro lado, amenizar "o isolamento corporativo da Magistratura e igualmente a anarquia controlada e irresponsável dos membros individuais do Judiciário". ${ }^{322}$ É importante o conhecimento de que tal modelo insere-se no "movimento no sentido de ver o Direito e a Justiça não mais no quadro da concepção tradicional dos que criam o direito, governam, julgam e administram, mas sim no quadro de concepção bem mais democrática, a dos consumidores do Direito e da Justiça". ${ }^{323}$ Por este modelo, a responsabilidade judicial "deve ser vista não em função do prestígio e da independência da magistratura enquanto $\operatorname{tal}^{324}$, mas em função dos usuários. A responsabilidade judicial aparece, assim, como elemento de um sistema de Justiça apto a conjugar imparcialidade

\footnotetext{
${ }^{319}$ Cappelletti, 1989, pp. 80-87 e Jobim, 2012, sem paginação.

320 Para Nelson Jobim (2012, sem paginação), a tradição judiciária republicana no Brasil aproxima-se deste tipo abstrato.

321 Cappelletti, 1989, p. 88-89. Interessante registrar que Mauro Cappelletti, embora reconhecendo que esse sistema pode ser bem menos perigoso às liberdades fundamentais dos cidadãos do que o sistema de sujeição do Judiciário ao poder político, afirmar que ele não é necessariamente menos danoso à sociedade moderna, que necessita de uma administração da Justiça razoavelmente ordenada e eficiente.

${ }^{322}$ Cappelletti, 1989, pp. 89-91.

${ }^{323}$ Cappelletti, 1989, pp. 89-90 e p. 95. Nesse sentido, Jobim, 2012, sem paginação.

${ }^{324}$ Nem em função do poder de uma entidade abstrata como o Estado ou o soberano - seja este um individuo ou a coletividade.
} 
“com razoável grau de abertura e de sensibilidade à sociedade e aos indivíduos que a compõem". 325

Uma classificação ligeiramente distinta é apresentada por Luigi Ferrajoli, que sistematiza os tipos de responsabilidade judiciária em três grupos: responsabilidade política - de cima para baixo, se o juiz é eleito, ou de baixo para cima, se ele é nomeado por órgãos do poder político; responsabilidade jurídica - que pode ser, de acordo com o caráter do ilícito, da sanção e dos procedimentos aplicados, subdividida em civil, penal ou disciplinar; e responsabilidade social, que se manifesta na "transparência da atividade judiciária” e na sua “ampla sujeição à crítica e ao controle da opinião pública". 326

Não se pode esquecer que a importante ressalva feita por Ferrajoli, no sentido de que "cada sistema de responsabilidade remeta a modelos de juízes diversos quanto às formas de seleção, quanto às fontes de legitimação política, quanto à posição institucional frente à sociedade e aos outros poderes do Estado", 327

Ao analisar os modelos de responsabilidade judicial e os modelos de juiz, Ferrajoli sustenta que, se, por um lado, existe um "nexo indissolúvel entre sujeição à lei, independência e responsabilidade dos juízes", de outro lado, "toda forma de responsabilidade pela ausência de sujeição à lei parece aludir a alguma forma de fiscalização sobre o mérito da função judicial" e "a alguma forma de dependência nos confrontos dos órgãos chamados a exercitá-la". 328

Apresentadas estas classificações, é oportuno que ponderar que não se pode esquecer, naturalmente, que os contornos da responsabilidade disciplinar podem mudar substancialmente de país para país, conforme sejam as diversas circunstâncias sociais, estruturais e organizacionais. ${ }^{329}$

Ademais, as responsabilidades - no sentido de poderes - processuais e substanciais dos juízes expandiram-se consideravelmente nas sociedades modernas. Por essa razão, avalia Cappelletti, é "natural que o correlativo problema da responsabilidade no sentido de accountability, ou seja, do dever de prestar contas - [também] tenha se tornado particularmente agudo".330

\footnotetext{
${ }^{325}$ Cappelletti, 1989, p. 91.

${ }^{326}$ Ferrajoli, 2010, p. 547.

${ }^{327}$ Ferrajoli, 2010, p. 547.

${ }^{328}$ Ferrajoli, 2010, p. 546.

${ }^{329}$ Cappelletti, 1989, p. 78.

${ }^{330}$ Cappelleti, 1989, p. 23.
} 


\section{IV.4. Competência disciplinar e accountability}

O termo accountability é de imprecisa tradução para a língua portuguesa. Seu significado, no entanto, é bastante claro, e revela-se por meio da noção de que todo agente ou órgão público deve prestar contas de seu trabalho, de seus resultados, e de sua eficiência. $^{331}$

De acordo com Leandro Rodrigues, a noção política de accountability carrega em si duas conotações básicas: dar explicações - answerability, que é a obrigação, por parte daqueles agentes ou órgãos de informar e explicar o que eles fazem - e coação legal - enforcement, que é a capacidade de organismos com poder de accountability de impor sanções aos detentores do poder que violarem suas obrigações públicas. ${ }^{332}$

A conotação de dar explicações demonstra que os ocupantes de cargos públicos devem responder por suas ações. Envolve o direito dos cidadãos e eleitores de receber informações e a obrigação correspondente dos ocupantes de cargos públicos de fornecer explicação que justifique a sua conduta. Sob a ótica de dar explicações, accountability envolve elementos de monitoração, não apenas formal - mediante os controles institucionalizados, mas também informal - dando amplo conhecimento público de ações desempenhadas. ${ }^{333}$

Enquanto a noção de dar explicações implica que o poder seja exercido de forma transparente e que seus atos sejam justificados, a noção de coação legal implica sujeitar o poder a sanções. ${ }^{334}$

Para Robl Filho, a estrutura conceitual da accountability é composta pelos elementos informações, justificações e sanção. Com efeito, a accountability pressupõe a existência de um agente que possui dever de apresentar informações e justificações sobre seus resultados e ações, podendo ser sancionado por um terceiro. ${ }^{335}$

\footnotetext{
${ }^{331}$ Rodrigues, 2008, p. 38. Este conceito inicial, apresentado por Rodrigues, pressupõe que esta prestação de contas é inerente ao funcionamento das modernas democracias. Nesse modelo, os governos, ainda que aparentemente centrados na representação do povo, são "conduzidos por uma pluralidade de grupos de interesses que competem entre si, respondendo a eleições livres e à liberdade de opinião e de associação.

${ }_{332}^{332}$ Rodrigues, 2008, p. 38.

${ }^{333}$ Rodrigues, 2008, p. 38.

${ }^{334}$ Rodrigues, 2008, p. 39. A definição de accountability é explicada por Rodrigues, valendo-se de Shedler, da seguinte forma: Pode-se resumir a ideia de accountability a partir do enunciado a seguir: "A deve prestar contas a B quando A é obrigado a informar B a respeito das ações e decisões de A (passadas e futuras), para justificá-las e sofrer a punição devida no coso de má conduta".

335 Robl Filho, 2012, p. 236-237.
} 
No mesmo sentido, Leandro Rodrigues afirma que em accountability geralmente os elementos informação, justificação e punição estão presentes. Entretanto, é possível que existam situações em que a ideia de accountability não englobe esses três elementos, ou seja, pode estar dissociada de algum de seus elementos nucleares, answerability ou enforcement, sem que isso desconfigure por completo a existência de accountability. $^{336}$

É importante que todo agente cujas atividades estejam sujeitas aos elementos de accountability detenha alguma capacidade de tomar decisões ou seja, "deve ser detentor de algum tipo de poder, ainda que pequeno". 337

Quanto à discussão sobre a quem prestar accountability, deve-se diferenciar accountability vertical de accountability horizontal. Essa distinção surgiu a partir da ideia piramidal de hierarquias, em que quanto mais alto no pirâmide, maior é o poder que se detém. $^{338}$

Dessa forma, uma relação vertical pressupõe uma relação entre desiguais. Essa desigualdade pode desestabilizar a estrutura da accountability. Nas democracias representativas, um exemplo de mecanismo de accountability vertical são as eleições, momento em que os cidadãos avaliam os representantes.

Por outro lado, accountability horizontal descreve uma relação entre iguais. Representa sua expressão típica a teoria da repartição de poderes, em que Executivo, Legislativo e Judiciário, atuando na forma de freios e contrapesos. ${ }^{339}$

Leandro Rodrigues ${ }^{340}$ afirma, por meio de reflexões teóricas e de pesquisas acerca da atuação do Conselho Nacional de Justiça durante o período entre 2005 a 2007, que é nítido o desenho institucional do Conselho, que goza de poderes de supervisão, de investigação e de sanção, como instrumento de accountability horizontal do Judiciário.

Taylor e Buranelli ${ }^{341}$ propõem que o conceito de accountability é composto por três estágios distintos: supervisão dos agentes públicos, com uma ênfase ex ante, ou

\footnotetext{
${ }^{336}$ Rodrigues, 2008, p. 39.

${ }^{337}$ Rodrigues, 2008, p. 39. "Sem a existência da capacidade de se tomar decisões, perde-se a razão da existência de accountability."

${ }^{338}$ Rodrigues, 2008 , p. 39.

339 Rodrigues, 2008, p. 39, que acrescenta a ressalva a existência de um debate acerca dos agentes de accountability horizontal, se esta deve ser somente entre relações de agentes estatais ou se pode estender-se a atores da sociedade civil.

${ }^{340}$ Rodrigues, 2008, p. 84.

${ }^{341}$ Taylor e Buranelli, 2005, sem paginação.
} 
seja, que a supervisão seja constante e ocorra anteriormente ao acontecimento das ações e omissões; investigação das alegações de conduta ilegal realizadas pelos agentes públicos, o que constitui numa ação ex post, com foco em descobrir a profundidade e extensão das condutas ilegais ocorridas e poder de sanção.

Assim, para que o Conselho Nacional de Justiça possa ser considerado como uma agência de accountability horizontal é preciso que ele tenha as três características mencionadas: i) capacidade de supervisão ex ante; ii) capacidade de investigação; iii) poder de sanção.

Esta distinção entre accountability horizontal e vertical também é proposta por Guillermo O'Donnell ${ }^{342}$, para quem accountability é mecanismo de controle social que deve haver sobre agentes públicos. Para O'Donnell, a accountability é vertical quando se realiza por meio das eleições e da liberdade de imprensa. Por outro lado, a accountability horizontal é atividade de controle exercida por agências estatais, que têm a autoridade legal e estão interessadas e capacitadas a supervisionar e têm ainda prerrogativas de impor sanções legais em relação às ações e omissões, que sejam consideradas ilícitas, de outros agentes ou agências estatais; assim, é horizontal quando se realiza por intermédio de agências internas de controle ${ }^{343}$.

Robl Filho, por sua vez, também faz a distinção entre accountability horizontal e vertical e, em acréscimo, aponta para uma subdivisão do conceito de accountability horizontal em legal e política e do conceito de accountability vertical, que apresenta as espécies eleitoral e não-eleitoral (social).

No que se refere à accountability horizontal, trata-se na linha das concepções de Leandro Rodrigues e Guillermo O`Donnell, da relação dos agentes estatais eleitos ou não eleitos entre si. Um agente estatal pode requerer informações e justificações de outro agente estatal, sendo possível aplicar sanções. As sanções são tomadas por violação do direito pelos agentes estatais - accountability horizontal legal - ou pela nãoconcordância dos agentes dotados do poder de sanção sobre decisão política de outro agente estatal - a accountability horizontal política. ${ }^{344}$

A accountability vertical eleitoral constitui-se na possibilidade de os cidadãos-eleitores sancionarem os políticos e os partidos políticos pelas ações e resultados

\footnotetext{
${ }^{342}$ Guillermo O’Donnell (1998, sem paginação), aponta

${ }^{343}$ Tribunal de Contas da União, à Controladoria-Geral da União e as várias corregedorias.

${ }^{344}$ Robl Filho, 2012, p. 237-238.
} 
políticos. Para que a accountability eleitoral aconteça, os cidadãos devem receber informações e justificações sobre as ações dos agentes estatais eleitos. ${ }^{345}$

A accountability vertical não-eleitoral (social) constitui-se na relação de grupos da sociedade civil e da imprensa com os agentes estatais eleitos ou não eleitos. Por meio da busca e da análise de informações e justificações dos agentes estatais, os grupos sociais e a imprensa podem sancioná-los por não alcançar os resultados políticos almejados ou por violar o direito. ${ }^{346}$ As sanções deste tipo de modalidade - accountability social - são a exposição pública dos agentes estatais e a formulação de denúncias aos órgãos de accountability horizontal responsáveis pela fiscalização dos agentes estatais.

Para Robl Filho, o enfoque da análise sobre o Conselho Nacional de Justiça não pode ser a independência judicial, já que o Conselho foi criado e possui competências de accountability. $^{347}$

Além disso, é imperioso ir além da análise do Conselho Nacional de Justiça a partir da categoria da accountability horizontal. Não há dúvidas de que a maior parte das competências do CNJ é exercida mediante mecanismos de accountability horizontal. ${ }^{348}$

Para uma análise mais apropriada do Conselho Nacional de Justiça, não é adequado utilizar apenas os conceitos de accountabilities vertical e horizontal, os quais são categorias que podem ser empregadas na compreensão de todos os poderes políticos e agentes estatais. Essas modalidades de accountability são necessárias, mas não suficientes na análise da função e do desenho institucional do Conselho. Desse modo, impõe-se o estudo das accountabilities judiciais decisional, comportamental e institucional, relacionando-as com as independências judiciais decisional e institucional e com as accountabilities eleitoral, horizontal e social. ${ }^{349}$

\footnotetext{
345 Robl Filho, 2012, p. 237, que acrescenta: "Precisa ser revista a forma pela qual as eleições são estruturadas, pois apenas um instrumento (voto) escolhe o programa dos candidatos e dos partidos (questão prospectiva) e sanciona os agentes estatais eleitos (accountability vertical eleitoral com função retrospectiva). Ainda, outras mudanças institucionais precisam ser feitas para maximizar a accountability vertical eleitoral."

${ }^{346}$ Robl Filho, 2012, p. 237.

${ }^{347}$ Robl Filho, 2012, p. 245. Por esta razão, Robl Filho faz a seguinte crítica ao trabalho de Sampaio (2007): “(...) há o ótimo trabalho de Sampaio - O Conselho Nacional de Justiça e a Independência do Judiciário. Trata-se de obra pioneira e vertical sobre o CNJ, porém não se concorda com a perspectiva posta já no título do livro: valorizar a análise do conselho por meio da categoria independência judicial, deixando em segundo plano a accountability.

${ }^{348}$ Robl Filho, 2012, p. 241.

${ }^{349}$ Robl Filho, 2012, p. 242-243
} 
Um conceito relacionado à accountability é o de independência judicial decisional, o que significa que "os magistrados possuem liberdade para interpretar as leis, a constituição e os costumes jurídicos no exercício da jurisdição".

Por correspondência, "accountability judicial decisional constitui-se na possibilidade de outro agente estatal ou particular de dirigir, de anular ou de rever a decisão judicial”. São formas legitimas de exercer accountability judicial decisional os recursos judiciais. ${ }^{350}$

Além disso, existe a independência judicial institucional, consistente na autonomia que o Poder Judiciário possui para realizar adequadamente sua atividade-fim o exercício da jurisdição. ${ }^{351}$ A accountability judicial institucional diz respeito ao poder de fiscalizar, influenciar e sancionar o judiciário como um poder, como uma instituição. ${ }^{352}$

Como o Poder Judiciário é composto por diversos agentes estatais (magistrados, órgãos e tribunais), a accountability judicial institucional também é exercida por alguns agentes do Judiciário sobre outros agentes judiciais. Em outras palavras, além da accountability judicial institucional externa, há a accountability judicial institucional interna. Esta forma de accountability é exercida pelo tribunal de maior hierarquia, pelos conselhos de justiça (quando a maioria dos membros são juízes), pela direção dos tribunais e pela corregedoria de justiça. ${ }^{353}$

O Conselho Nacional de Justiça detém poderes de accountabilities judiciais institucional e comportamental. Desse modo, o Conselho é um agente estatal de accountability judicial institucional interno, pois sua atuação promove principalmente um redesenho parcial das relações de poder administrativo, disciplinar, orçamentário e financeiro no seio do Judiciário. Há também elementos de accountability judicial institucional externa, em razão de quarenta por cento dos conselheiros não serem

\footnotetext{
${ }^{350}$ Robl Filho, 2012, pp. 237-238.

${ }^{351}$ Robl Filho (2012, pp. 238-239) relata que são diversos os elementos que compõem a independência judicial institucional como poder de seleção dos magistrados e de servidores auxiliares, exercício do poder disciplinar sobre magistrados e servidores auxiliares, autonomias administrativa, financeira e orçamentária, garantias funcionais como vitaliciedade, irredutibilidade de salários e inamovibilidade, possibilidade de participar do processo legislativo de atos normativos relevantes para a magistratura e para a gestão da justiça, observância dos comandos judiciais pelos outros agentes estatais, participação dos outros agentes estatais na concretização dos interesses da magistratura e outras questões.

352 Robl Filho, 2012, p. 239.

${ }^{353}$ Robl Filho, 2012, p. 239-240.
} 
magistrados e devido ao fornecimento de maiores informações à população sobre o judiciário, permitindo o exercício de accountability judicial institucional social. ${ }^{354}$

O exercício das competências do Conselho Nacional de Justiça promovem principalmente a accountability horizontal, pois o Conselho exige informações e justificações dos magistrados, tribunais, servidores auxiliares, cartórios e notários, podendo sancioná-los. De outro lado, por meio da concretização do princípio da publicidade no Judiciário, do recebimento de denúncias de ilícitos disciplinares de agentes judiciais, da existência de ouvidorias de justiça e da apresentação de relatórios, o Conselho possibilita o exercício de accountabilities sociais judiciais institucional e comportamental. ${ }^{355}$

De outro lado, deve-se reconhecer que o Conselho também detém função de participar de uma rede de accountability social - vertical não-eleitoral - judicial. Esta forma de accountability não pode ser desprezada no estudo do Conselho Nacional de Justiça. ${ }^{356}$ Robl Filho defende que o Conselho detém, no Estado Democrático de Direito brasileiro, ${ }^{357}$ a função de colmatar lacunas de accountabilities judiciais institucional e comportamental por meio de mecanismos de accountabilities horizontal e vertical nãoeleitoral.

Cumpre apresentar, por fim, uma importante crítica de Robl Filho, para quem faz-se necessário, no âmbito do Poder Judiciário, a sedimentação de uma nova cultura da Magistratura nacional, que articule seus predicados institucionais estanques independência, autogoverno e autonomia - com a ideia de accountability e democratização. ${ }^{358}$

\section{IV.5. Competência disciplinar e princípio da publicidade}

No item IV.3., demonstrou-se a importância de se assegurar a independência do Poder Judiciário e da Magistratura, bem como o necessário contraponto

\footnotetext{
${ }^{354}$ Robl Filho, 2012, p. 243.

${ }^{355}$ Robl Filho, 2012, p. 244.

${ }^{356}$ Robl Filho, 2012, p. 242

${ }^{357}$ Para Robl Filho (2012, p. 241), o Brasil possui instrumentos de accountability e luta pela implantação desses mecanismos, tendo dificuldades, assim como todos os Estados Democráticos de Direito possuem, em concretizar as diversas modalidades de accountability.

${ }^{358}$ Guerra, 2010, p. 76.
} 
que deve ser feito, em busca de um equilíbrio, com a noção em torno da responsabilização dos juízes.

Com efeito, é importante que seja preservada, em intenso grau, a autonomia dos juízes. Esta autonomia, todavia, "não deve ser fechada, mas sim aberta às instâncias da sociedade". Para amenizar o risco da clausura corporativa, "particularmente ameaçadora numa Magistratura de carreira", devem-se adotar os instrumentos normativos, organizativos e estruturais que possam tornar a autonomia dos juízes aberta ao corpo social e, assim, às solicitações dos jurisdicionados. Incluem-se, entre tais instrumentos, "as formas de responsabilidade de prestação de contas, políticas, sociais e jurídicas". 359

Neste ponto, é oportuno ressaltar a importância de associar a função disciplinar do Conselho Nacional de Justiça ao princípio da publicidade.

Em um Estado Democrático de Direito, é essencial, para a independência do Poder Judiciário, a publicidade ampla de seus atos administrativos e jurisdicionais, com o objetivo de que os cidadãos tenham consciência de sua importância social e política, participando e participe ativamente da proteção de sua independência.

Excepcionalmente, contudo, em casos de nítido interesse público ou de manifesta necessidade para a proteção de direitos individuais, podem ser admitidos processos judiciais com publicidade restrita - jamais devendo ser tolerado, contudo, o sigilo sobre questões administrativas de interesse do Judiciário. ${ }^{360}$

De fato, a garantia da publicidade dos atos praticados pelos tribunais, centros de onde emanam importantes decisões administrativas, representa uma dupla repercussão democrática ${ }^{361}$ : uma interna, preservando o respeito e a dignidade da Magistratura, e outra externa, que está ligada diretamente à satisfação social ${ }^{362}$.

Um mecanismo que objetiva conferir maior transparência e publicidade aos atos do Poder Judiciário consiste, na percepção de José Adércio Leite Sampaio ${ }^{363}$, na possibilidade de qualquer cidadão poder acionar o poder correcional - enquanto as autoridades públicas terão o dever de fazê-lo. Interessante ressaltar o poder de provocação

\footnotetext{
${ }^{359}$ Cappelletti, 1989, pp. 92-93.

${ }^{360}$ Dallari, 2008, p. 156.

${ }^{361}$ Deocleciano, 2010, p. 82-83.

${ }^{362} \mathrm{Um}$ exemplo de decisão do CNJ sustentando a necessidade de se observar o princípio da publicidade às decisões quando da tomada de decisões administrativas por parte dos tribunais foi a proferida no Procedimento de Controle Administrativo n. 35/2005, em que foi relator o Conselheiro Douglas Rodrigues.

${ }^{363}$ Sampaio, 2007.
} 
pelo cidadão, permitindo sua participação, mesmo que indireta, na apuração da forma como a jurisdição é ofertada e se as determinações estabelecidas pelo Conselho decorrentes da Constituição, da LOMAN, da Lei n. 8.112/91 e da Lei n. 9.784/99 - estão sendo observadas a contento.

Visando à maior aderência do Conselho Nacional de Justiça à vida do Poder Judiciário e integração nos problemas que atingem os consumidores dos serviços deste, a Constituição Federal prevê que se instituam as ouvidorias de justiça. ${ }^{364}$ Trata-se de autênticos e legítimos canais de comunicação entre a população e o Conselho, sendo “competentes para reclamações e denúncias de qualquer interessado contra membros ou órgãos do Poder Judiciário ou contra seus serviços auxiliares, representando diretamente ao Conselho Nacional de Justiça". ${ }^{365}$

\section{IV.6. Natureza da competência disciplinar do Conselho Nacional de Justiça,} relativamente às atribuições das corregedorias dos tribunais em geral: concorrente ou subsidiária?

Antes de se examinar os contornos da competência disciplinar do Conselho Nacional de Justiça com o objetivo de definir qual é a sua natureza jurídica em relação às atribuições das corregedorias dos tribunais em geral, é fundamental que se tenha em consideração que tal competência tem natureza exclusivamente administrativa, não se confundindo, jamais, com competência de caráter jurisdicional.

Com efeito, é importante que se esclareça que, no exercício de suas funções disciplinares, o Conselho Nacional de Justiça não pode discutir a o mérito das decisões proferidas pelos juízes, não podendo interferir no conteúdo jurisdicional dos provimentos judiciais, sob pena de incorrer em desvio de finalidade.

Em decorrência desta natureza administrativa, os atos administrativos desempenhados nas atividades afeitas ao exercício da competência disciplinar devem estar

\footnotetext{
${ }^{364}$ Sampaio, 2007, p. 296. Sobre a atribuição de Ouvidoria do CNJ, José Adércio Leite Sampaio afirma que "todo e qualquer expediente que não tenha classificação específica (por exemplo, pedido de inspeção ou de sindicância) nem seja acessório ou incidente será incluído na classe de pedido de providências, se contiver requerimento formulado por escrito ou reduzido a termo, com a identificação e o endereço do requerente". ${ }^{365}$ Dinamarco, 2009, p. 421.
} 
orientados por um fim impessoal. Nesse sentido, deve-se lembrar sempre da lição de Ruy Cirne Lima, para quem o traço característico da atividade administrativa é estar vinculada - não a uma vontade personalidade - mas a um fim impessoal. ${ }^{366}$

Foi visto, no item IV.3. deste capítulo, que a competência disciplinar do Conselho Nacional de Justiça, no sentido de poder-dever constitucionalmente estabelecido, situa-se entre a independência e a responsabilidade judicial. Ao mesmo tempo, mas agora no sentido de conjunto de atribuições conferidas ao Conselho, tal competência - refletida na edição do artigo 12 da Resolução n. 135, de 13 de julho de 2011 - localiza-se entre a necessidade de compatibilização do princípio da autonomia dos Tribunais $^{367}$, e as competências constitucionais originárias do Conselho ${ }^{368}$, no âmbito disciplinar.

Logo de início já é possível sustentar que o texto constitucional é bastante claro, no inciso III, do parágrafo $4^{\circ}$, do artigo $103-\mathrm{B}^{369}$, ao estabelecer alguns importantes preceitos em relação à competência disciplinar do Conselho Nacional de Justiça. ${ }^{370}$

Da simples leitura deste dispositivo constitucional, observa-se que se trata de competência originária com substrato normativo retirado diretamente do texto constitucional, independentemente de outras atribuições que lhe possam ser conferidas pelo Estatuto da Magistratura.

Com efeito, a Emenda Constitucional n. 45/2004 estabeleceu diretamente no texto da Constituição as competências originárias do órgão administrativo de cúpula do Poder Judiciário, admitindo novas competências recursais, por meio de lei, por meio do Estatuto da Magistratura, ou Lei Complementar de iniciativa exclusiva do Supremo Tribunal Federal ${ }^{371}$.

\footnotetext{
${ }^{366}$ Cirne Lima, 2007, p. 385.

${ }^{367}$ Constituição da República, arts. 96, inciso I e 99.

${ }^{368}$ Constituição da República, art. 103-B, $\S 4^{\circ}$, III e $\S 5^{\circ}$, I, II e III.

${ }^{369}$ Constituição da República, art. 103-B, §4", III: "receber e conhecer das reclamações contra membros ou órgãos do Poder Judiciário, inclusive contra seus serviços auxiliares, serventias e órgãos prestadores de serviços notariais e de registro que atuem por delegação do poder público ou oficializados, sem prejuízo da competência disciplinar e correicional dos tribunais, podendo avocar processos disciplinares em curso e determinar a remoção, a disponibilidade ou a aposentadoria com subsídios ou proventos proporcionais ao tempo de serviço e aplicar outras sanções administrativas, assegurada ampla defesa"

${ }^{370}$ Alteração do RICNJ para se adequar ao texto constitucional - ver. art. $4^{\circ}$, III.

${ }^{371}$ A excepcionalidade da fixação das competências disciplinares originárias do CNJ, assim como ocorre em relação às competências jurisdicionais originárias do STF, exige previsão expressa e taxativa do texto constitucional.
} 
Depreende-se, além disso, que se aplica não apenas aos Magistrados, mas também aos serviços auxiliares, serventias e órgãos prestadores de serviços notariais e de registro que atuem por delegação do poder público ou oficializados.

Em linhas gerais, pode-se afirmar que o Conselho Nacional de Justiça foi dotado de ampla competência disciplinar, situando-se como órgão central do controle correcional do Judiciário nacional. Esta atuação constitucional originária do Conselho Nacional de Justiça direciona-se para duas importantes missões: o controle da atuação administrativa e financeira do Poder Judiciário e o controle do cumprimento dos deveres funcionais dos juízes e órgão auxiliares do Poder Judiciário.

Para a Ministra Eliana Calmon, do Superior Tribunal de Justiça e ExCorregedora Nacional de Justiça, o estabelecimento da competência disciplinar do Conselho Nacional de Justiça foi uma decisão acertada ${ }^{372}$. Sua justificativa para tanto é que, uma vez que se vislumbrou a impossibilidade de concentração em um só órgão do poder disciplinar de toda a Magistratura, o Constituinte Reformador de 2004 manteve a competência disciplinar dos Tribunais de Justiça, sem descartar a atuação pronta e imediata da Corregedoria Nacional, em concorrência harmoniosa, possibilitando assim a atuação do Conselho Nacional de Justiça, quando não o fizesse a Corregedoria local. ${ }^{373}$

Além de ter estabelecido expressamente como competência originária do Conselho Nacional de Justiça a sua atividade disciplinar, o legislador constituinte reformador de 2004 instrumentalizou o Conselho com a criação do cargo de MinistroCorregedor, ao qual se conferiu, também, competências originárias diretamente previstas pelo texto constitucional.

Todas as normas contidas no art. 103-B da Constituição da República que refletem as atribuições do Conselho Nacional de Justiça evidenciam que suas atribuições são imediatamente concorrentes às das corregedorias dos tribunais locais. Em relação ao princípio da eficiência, a concorrência de competências, conforme estabelecida pela Emenda Constitucional n. 45/2004, teve por finalidade melhorar a fiscalização disciplinar no âmbito do Poder Judiciário. Não se pode afastar de "qualquer interessado" 374, a possibilidade de acessar diretamente o Conselho Nacional de Justiça, o qual foi alçado pela Emenda Constitucional n. 45/2004 como verdadeiro "juiz natural" para as questões

\footnotetext{
${ }^{372}$ Calmon, 2012, sem paginação.

${ }^{373}$ Calmon, 2012, sem paginação.

${ }^{374} \mathrm{CF}$, art. $103-\mathrm{B}, \S 5^{\circ}, \mathrm{I}$
} 
disciplinares da Magistratura, sob pena de ferimento ao Estado de Direito e descrédito perante a sociedade. ${ }^{375}$

Ao analisar o conteúdo do art. 103-B, parágrafo $4^{\circ}$, da Constituição da República, Lionel Zaclis ${ }^{376}$ pondera que significado de suas disposições parece extremamente claro no sentido de atribuir ao Conselho Nacional de Justiça poder correcional e disciplinar originário, sem prejuízo da competência concorrente das corregedorias estaduais.

Nesse sentido, Zaclis aponta que "o óbvio é sempre muito difícil de ser explicado, ante o risco de incidência em tautologia". Para tanto, recorre ao seguinte exemplo: “dizer que A tem determinada competência, 'sem prejuízo' da competência de B, significa dizer que a competência de $\mathrm{A}$ não prejudica a competência de $\mathrm{B}$, que, por isso mesmo, não fica impedido de exercê-la. Em outras palavras, clara situação de competência concorrente". 377

O próprio Supremo Tribunal Federal, no julgamento da ADI n. 3367, apontou essa relação de concorrência - tanto o Conselho Nacional de Justiça quanto as corregedorias locais podem iniciar processos disciplinares contra magistrados -, e não de subsidiariedade - o Conselho Nacional de Justiça só entra em cena quando as corregedorias não atuaram.

É importante que se lembre que o Conselho Nacional de Justiça foi instituído em razão da perda significativa da credibilidade nas corregedorias judiciais e na própria, efetiva ou aparente, lisura e razoável prestação jurisdicional, ante a impunidade de ilícitos funcionais graves ou mais retóricas do que prática. ${ }^{378}$

Trabalhos congressuais e publicações especializadas relatam que o modelo anterior não funcionava e, por isso, o Conselho Nacional de Justiça foi criado também como órgão de planejamento nacional do Judiciário. ${ }^{379}$

Para o Ministro Celso de Mello, do Supremo Tribunal Federal ${ }^{380}$, a competência é subsidiária, devendo o Conselho Nacional de Justiça atuar apenas em quatro

\footnotetext{
${ }^{375}$ Nobre, 2011, sem paginação.

${ }^{376}$ Zaclis, 2012, sem paginação.

377 Zaclis, 2012, sem paginação. E vai além, afirmando que "se o Conselho Nacional de Justiça tem o poder de rever os processos disciplinares decididos há menos de um ano pelas corregedorias, com muito maior razão detém o poder de instaurar e de decidir processos disciplinares".

${ }^{378}$ Flurh, 2011, p. 80, como já mencionado no primeiro capítulo.

${ }^{379}$ Nobre, 2011, sem paginação.
} 
hipóteses: a) quando as corregedoria locais deixassem de fazê-lo (inércia); b) quanto "pretextassem fazê-lo" (simulação); c) quando demonstrassem incapacidade de fazê-lo (falta de independência); d) quando, dentre outros comportamentos evasivos, protelassem, sem justa causa, o seu exercício (procrastinação indevida).

Sobre tais hipóteses trazidas pelo Ministro Celso de Mello, Zaclis pondera que se trata de critérios não propriamente de ordem jurídica, mas, sim, de caráter meramente pragmático. Analisando tais critérios um pouco mais detalhadamente, assevera: "mas, admitindo-se, ad argumentandum tantum, que se devesse implementar, previamente, uma ou mais das hipóteses referidas para que o Conselho Nacional de Justiça pudesse atuar, caberia a indagação: do ponto de vista jurídico, qual a diferença que haveria em relação a uma competência originária, concorrente? Não haveria, relativamente aos Tribunais estaduais, a mesma interferência por parte de um órgão controlador nacional?”,381 O Ex-Ministro Nelson Jobim chama a atenção para uma interessante questão intercorrente: a quem competirá o juízo sobre a existência, ou não, em concreto, dos requisitos arrolados? Se competir ao CNJ, poderá haver controle por parte do Supremo Tribunal Federal? ${ }^{382}$

A defesa da tese da subsidiariedade também aponta que haveria invasões indevidas da competência disciplinar e correcional dos Tribunais, de modo que estes deixariam de ser a instância constitucional originária, para se transformarem em meros coadjuvantes do Conselho Nacional de Justiça.

Contudo, a aplicação do princípio da subsidiariedade não é compatível com a efetividade das atividades administrativas de fiscalização e controle. A aplicação desse princípio só teria algum cabimento nos estritos termos propostos pelo Ministro Gilmar Mendes em audiência na Comissão de Constituição, Justiça e Cidadania do Senado

\footnotetext{
${ }^{380}$ Antes da decisão da ADI 4638, o STF manifestou-se, em algumas ocasiões, no sentido de conferir um caráter subsidiário à competência disciplinar do CNJ. Assim o fez, por exemplo, no MS 28.350 - Rel. Ministro Eros Grau; MS 28.884-MC e MS 28.801 - Rel. Ministro Celso de Mello. "Dessa maneira, a incidência do postulado da subsidiariedade, como requisito legitimados da prática concreta, pelo Conselho Nacional de Justiça, de uma competência complementar em matéria correcional, disciplinar e/ou administrativa, não só harmoniza o exercício dessa jurisdição censória com o princípio da autonomia institucional dos Tribunais, como conferira, também, maior coeficiente de legitimidade jurídica à atuação desse órgão estatal, propiciando-se, desse modo, nos termos da abordagem ora preconizada, a análise do tema sob a perspectiva dos múltiplos valores constitucionais envolvidos. Outro caso foi o MS 28.884 (Rel. Ministro Marco Aurélio) - caso do Juiz de São João Del Rei que colocou arma de fogo sobre a mesa de audiência; MS contra a decisão do CNJ que anulou advertência aplicada pela Corregedoria Geral da Justiça do Estado de Minas Gerais e aplicou pena de remoção compulsória, em razão da prática de conduta incompatível com os deveres funcionais arrolados nos incisos I, IV e VIII do artigo 35 da LOMAN. Neste MS, o Relator apresenta-se contrário à tese da competência concorrente".

${ }^{381}$ Zaclis, 2012, sem paginação.

382 Jobim, 2012, sem paginação. Note-se que é feita referência à classificação proposta por Cappelletti, já abordada no item IV.3 supra.
} 
Federal, isto é, como um filtro aplicado pelo próprio Conselho, de modo a evitar que "se embaralhe com a atividade dos casos repetidos, dos casuísmos que se repetem e que são desafiadores".

Assim, o Conselho Nacional de Justiça estabelece como parâmetro de apreciação o princípio da subsidiariedade, ou seja, em regra, não terá competência para apreciar qualquer questão, mas aquelas que guardem relevância geral ou que tenham correlação com a atuação dos órgãos correcionais inferiores ou quando se relacionem com a autoridade de suas determinações. Às vésperas de tomar posse na presidência do Conselho Nacional de Justiça, o Ministro Gilmar Mendes deixou bem clara a necessidade da adoção de tal princípio, pois, segundo ele, "não cabe ao Conselho Nacional de Justiça dar resposta à angústia tópica que mora em cada processo",383.

Fora dessa hipótese, de autocontenção para evitar envolvimento em questões menos importantes, reclamações repetitivas e problemas que não apresentem relevância para merecer atuação de um órgão nacional de controle administrativo e disciplinar, a atuação apenas subsidiária do Conselho Nacional de Justiça no campo correcional será um retrocesso.

Como se já não bastassem esses argumentos, a tese da competência subsidiária não se sustenta juridicamente. É certo que a tese da subsidiariedade está em desacordo, com o caráter unitário do Poder Judiciário, salientado na ADI n. 3367. Além disso, o art. 103-B, em seu quarto parágrafo, estabelece como competência do Conselho Nacional de Justiça o controle da "a atuação administrativa e financeira do Poder Judiciário e do cumprimento dos deveres funcionais dos juízes". ${ }^{384} \mathrm{O}$ inciso III do mesmo parágrafo define que o órgão pode receber e conhecer reclamações contra membros ou órgãos do Judiciário, "sem prejuízo da competência disciplinar e correcional dos tribunais", podendo avocar processos disciplinares e aplicar sanções. Está claro que a competência do Conselho Nacional de Justiça é "concorrente" à dos tribunais. "Sem prejuízo de" não significa "em vez de" ou "depois de", mas que cada qual terá o seu papel". 385

\footnotetext{
${ }^{383}$ Mendes, 2008, sem paginação.

${ }^{384}$ D’Urso, 2011, sem paginação.

${ }^{385}$ D’Urso, 2011, sem paginação.
} 
Ao utilizar a expressão "sem prejuizo", o constituinte derivado reformador determinou que a competência do $\mathrm{CNJ}$ não eliminasse as já existentes das corregedorias e dos tribunais, em matéria de processo administrativo disciplinar.

É importante considerar também que expressão "sem prejuizo de" é utilizada ao longo do texto constitucional em diversas oportunidades. Em todas elas, a interpretação adequada se dirige em concluir pela adição e não exclusão. Assim ocorre, por exemplo, com o artigo 150, inciso I, ao estabelecer as garantias dos contribuintes; com artigo $7^{\circ}$, XVIII, ao estabelecer o direito da licença à gestante; com o artigo 30, inciso III, sobre a obrigatoriedade de prestação de contas; e, de modo emblemático, com o artigo 37, parágrafo $4^{\circ}$, pelo qual “os atos de improbidade administrativa importarão a suspensão dos direitos políticos, a perda da função pública, a indisponibilidade dos bens e o ressarcimento ao erário, na forma e gradação previstas em lei, sem prejuízo da ação penal cabível". ${ }^{386}$

Em se tratando de punição a agente do poder estatal, a Constituição costumeiramente admite o acúmulo de responsabilidades, utilizando-se a expressão em tela para significar aplicação concorrente, como exemplificam o artigo 52, parágrafo único e o artigo 86 da Constituição Federal. ${ }^{387}$ Em ambos os casos, a Emenda Constitucional n. $45 / 2004$ buscou estabelecer a possibilidade de efetivo controle administrativo centralizado de legalidade sobre a atuação dos diversos juízos e tribunais, sem prejuízo dos controles administrativos e disciplinares de cada tribunal e do controle jurisdicional, bem como sem prejuízo da autonomia financeira e administrativa que a Constituição da República consagrou aos Tribunais desde seu texto original e manteve com as alterações introduzidas pela Emenda Constitucional n. 45/2004.

Uma interpretação sistemática do texto constitucional evidencia que a expressão "sem prejuizo de" não tem o sentido de aplicabilidade preferencial de uma das normas. Ao contrário, veicula uma conjunção de normas, que têm aplicação concorrente e cumulativa. $^{388}$

Nesse sentido também é a norma contida no art. 103-B, $\S 4^{\circ}$, inciso II, segundo o qual compete ao Conselho Nacional de Justiça apreciar a legalidade dos atos

\footnotetext{
${ }^{386}$ Coelho, 2012, sem paginação. Um contraponto ao entendimento deste autor é feito por Sérgio Niemeyer, que defende que a competência não é nem pode ser corrente (Niemeyer, 2012, sem paginação).

${ }^{387}$ Coelho, 2012, sem paginação.

${ }^{388}$ Com efeito, é com esse sentido que a expressão é utilizada, por exemplo, nos arts. 103-B, § 4º II, 144, $\S 1^{\circ}$, II, 146-A, 166, $\S 1^{\circ}$, II, da Constituição da República, bem como nos arts. 62 e 77, $\S 3^{\circ}$, do Ato das Disposições Constitucionais Transitórias. Tais dispositivos tratam de atribuições exercidas sem prejuízo de outras, no sentido de que o exercício de uma não está condicionado ao não-exercício de outra.
} 
administrativos praticados pelos membros do Poder Judiciário, sem prejuízo da competência do Tribunal de Contas da União. Tal competência não é exercida apenas em caso de inação do TCU, tampouco está condicionada à inércia desse órgão, mesmo após ser formalmente provocado. Trata-se, ao contrário, de competências desempenhadas paralelamente.

A expressão "sem prejuizo", ao contrário de criar uma instância recursal ou uma instituição fiscalizadora de segunda linha, quer dizer apenas que, a despeito da existência do novo órgão disciplinar e correcional, os tribunais não perderam suas atribuições quanto a essa matéria. ${ }^{389}$

A interpretação razoável a partir da Emenda Constitucional n. 45/2004 continua sendo a de que os Tribunais ${ }^{390}$ continuam não só organizando suas Corregedorias, mas também exercendo sua função correcional em relação às suas secretarias e serviços auxiliares, bem como em relação aos juízos que lhes forem vinculados. Porém, o que era, até a edição da Emenda Constitucional n. 45/2004, exclusivo e terminativo, tornou-se concorrente e não terminativo ${ }^{391}$.

Importante salientar também que o afastamento de forma absoluta da competência concorrente em matéria disciplinar, afastaria a possibilidade de "qualquer interessado ${ }^{, 392}$, inclusive do próprio Magistrado ou servidor do Poder Judiciário, em poder dirigir-se diretamente, em matéria disciplinar ao Conselho Nacional de Justiça, em flagrante desrespeito ao princípio da eficiência e ao princípio do juiz natural, consagrado constitucionalmente.

Ressalte-se, que a alteração trazida em sede disciplinar e correcional pela Emenda Constitucional n. 45/2004, não foi somente em relação à exclusividade de seu exercício pelos Tribunais em relação aos respectivos órgão e serventias vinculados; mas também ao seu caráter terminativo, que deixou de existir.

Com efeito, tanto o inciso III, do $\S 4^{\mathrm{o} 393}$, quanto o inciso I, do $\S 5^{0394}$, ambos do artigo 103-B, consagram o caráter não-terminativo da função disciplinar e correcional

\footnotetext{
${ }^{389}$ Nobre, 2011, sem paginação.

${ }^{390}$ Nos termos do art. 96, I, b, da Constituição da República.

${ }^{391}$ Nos termos do artigo $103-\mathrm{B}, \S 4^{\circ}$, III e $\S 5^{\circ}$, I e II da Constituição da República.

${ }^{392}$ Constituição da República, art. 103-B, parágrafo $5^{\circ}$, inciso I.

393 "Podendo avocar processos disciplinares em curso"

394 "Receber as reclamações e denúncias, de qualquer interessado, relativas aos magistrados e aos serviços judiciários"
} 
dos tribunais, a partir da Emenda Constitucional n. 45/2004, pois o processo disciplinar poderá ser novamente analisado pelo Conselho Nacional de Justiça.

Nos termos do voto do Ministro Cezar Peluso, Relator da ADI n. 3367, "longe, pois, de conspirar contra a independência judicial, a criação de um órgão com poderes de controle nacional dos deveres funcionais dos Magistrados responde a uma imperfeiç ão contingente do Poder, no contexto do sistema republicano de governo. Afinal, regime republicano é regime de responsabilidade".

Além disso, o exercício das competências do CNJ não se condiciona um pronunciamento prévio das corregedorias e tribunais. Caso objetivasse conferir ao Conselho atribuições meramente revisionais, o legislador não teria, por exemplo, estabelecido a possibilidade de avocação de procedimentos em curso, limitando-se a outorgar-lhes os poderes estabelecidos no art. 103-B, $\S 4^{\circ}, \mathrm{V}$.

De acordo com a justificação constante do texto da PEC 97, de $2011^{395}$, a análise do art. 103-B, $\S 4^{\circ}$, III, da Constituição, compete ao Conselho Nacional de Justiça receber e conhecer das reclamações, e não aguardar que o tribunal de origem julgue tampouco devolver ao tribunal de origem para que processe e julgue. Dessa forma, a competência disposta na Constituição é expressamente concorrente, e não subsidiária, porque não pode o Conselho conhecer da reclamação e não julgá-la.

É assim porque sabidamente os tribunais não estavam, neste tema, funcionando adequadamente. As corregedorias não estavam cumprindo o seu papel, e essa constatação foi objeto de fundamento para que o Supremo Tribunal Federal pudesse decidir pela constitucionalidade da Emenda Constitucional n. 45, de 2004.

No que concerne diretamente ao tema deste trabalho, a Proposta de Emenda Constitucional n. 97/2011 propõe a alteração da redação do art. 103-B da Constituição

\footnotetext{
${ }^{395}$ Em dezembro de 2012, consultou-se seu andamento legislativo da PEC 97/2011- tramitação no Congresso Nacional - e verificou-se que, desde 28 de fevereiro de 2012, está aguardando parecer da Comissão de Constituição e Justiça do Senado Federal, conjuntamente com a PEC n. 42/2007 e com a PEC n. 51/2007. "Ainda que a opção do Constituinte tenha sido atuação concorrente do CNJ, exatamente para resgatar dignidade do próprio Poder Judiciário, diante da dúvida suscitada, e para aprimorar as competências do Conselho e de sua Corregedoria Nacional de Justiça, é de fundamental importância que o Congresso Nacional tenha a oportunidade de mais uma vez dispor sobre a matéria. (...) no âmbito da Corregedoria Nacional de Justiça que audiências públicas e inspeções nos tribunais têm revelado graves irregularidade em relação ao funcionamento da justiça, notadamente no campo disciplinar".
} 


\section{Federal com o objetivo de eliminar qualquer dúvida interpretativa acerca do caráter concorrente da competência disciplinar do Conselho Nacional de Justiça. ${ }^{396}$}

$\mathrm{Na}$ hipótese de haver um processo administrativo disciplinar instaurado perante uma Corregedoria local, como regra geral, tem-se que o julgamento deve ser realizado pela própria Corregedoria local. Nesse caso, tal processo pode ser revisto posteriormente pelo Conselho Nacional de Justiça, nos termos do art. 103-B, Parágrafo $4^{\mathrm{o}}$,

${ }^{396}$ Com efeito, a PEC 97/2011 tem por objeto: Determinar que compete ao Conselho Nacional de Justiça: processar e julgar, mediante provocação de qualquer pessoa, faltas disciplinares de juízes, serventuários da Justiça e dos foros extrajudiciais, podendo aplicar, além das penas já constantes do texto constitucional, as de advertência e censura, inclusive a juízes de segunda instância e dos tribunais superiores, bem como outras sanções administrativas, garantida a ampla defesa (inciso III do $\S 4^{\circ}$ ); e avocar e rever, de ofício ou mediante provocação de qualquer pessoa, os processos ou procedimentos disciplinares, envolvendo os mesmos sujeitos, julgados ou arquivados há menos de cinco anos (inciso $\mathrm{V}$ do $\S 4^{\circ}$ ); Acrescenta $\S \S 4^{\circ}$-A e $5^{\circ}$-A e altera a redação do $\S 5^{\circ}$ do mesmo artigo 103-B, para tornar clara a competência da Corregedoria Nacional de Justiça, autônoma e concorrente em relação aos órgãos administrativos dos tribunais, podendo instaurar procedimentos e propor ao plenário do Conselho Nacional de Justiça a abertura de processo administrativo disciplinar, requisitar informações, exames, perícias ou documentos, sigilosos ou não, imprescindíveis ao esclarecimento de processos ou procedimentos sob sua apreciação; dispõe que a abertura de processo administrativo disciplinar pelo plenário do Conselho Nacional de Justiça suspende, até deliberação final, a instauração ou o prosseguimento de procedimentos similares nos tribunais. Determina que, enquanto não houver lei específica, o Conselho Nacional de Justiça disciplinará, por resolução, seu funcionamento e as atribuições da Corregedoria Nacional de Justiça, sem prejuízo daquelas constantes do art. 103-B da Constituição Federal, na redação dada pela presente proposta. Explicita as competências do Conselho Nacional de Justiça para processar e julgar, de ofício ou mediante provocação de qualquer pessoa, faltas disciplinares praticadas por membros ou órgãos do Poder Judiciário e auxiliares da justiça, ou de serventias do foro extrajudicial, podendo determinar a remoção, a disponibilidade ou a aposentadoria com subsídios ou proventos proporcionais ao tempo de serviço, aplicar advertência e censura, inclusive em relação aos magistrados de segunda instância e dos tribunais superiores, bem como outras sanções administrativas, assegurada ampla defesa; Confere competência ao Conselho Nacional de Justiça para avocar não apenas processos disciplinares em curso, mas também procedimentos prévios de apuração; Estende de um para cinco anos o prazo de exercício, pelo Conselho Nacional de Justiça, da competência para rever processos disciplinares contra magistrados e prevê essa mesma competência revisional em relação a processos disciplinares contra auxiliares da justiça ou de serventias do foro extrajudicial; Explicita o caráter autônomo e concorrente da competência do Conselho Nacional de Justiça e da Corregedoria Nacional de Justiça, em relação aos órgãos administrativos dos tribunais, e confere à instauração de processo disciplinar ou procedimento de apuração no âmbito do Conselho Nacional de Justiça efeito suspensivo, até deliberação final, da tramitação de procedimentos similares nos tribunais confere status constitucional à Corregedoria Nacional de Justiça (o texto atual da Carta Magna apenas se refere ao cargo de Ministro-Corregedor) e permite a criação, por meio de lei (e não mais do Estatuto Nacional da Magistratura), de outras atribuições para o órgão, além daquelas que enumera; Explicita as competências correcionais para instaurar, de oficio ou mediante provocação de qualquer pessoa (o texto constitucional vigente fala em provocação apenas de interessados), procedimentos dirigidos à apuração de faltas disciplinares, inclusive das praticadas no âmbito das serventias do foro extrajudicial, e de propor ao plenário do Conselho Nacional de Justiça a abertura de processo administrativo disciplinar; Conferir poderes à Corregedoria Nacional de Justiça para requisitar informações, exames, perícias ou documentos, sigilosos ou não, das autoridades físcais, monetárias e outras competentes, quando imprescindível ao esclarecimento de processos ou procedimentos submetidos à sua apreciação. Outro ponto importante em relação ao CNJ que é objeto da PEC 97 é a proposta de alteração do art. 102 da Constituição Federal, para explicitar, nas alíneas b e r do inciso I, a competência do Supremo Tribunal Federal para processar e julgar, nos crimes comuns, os membros do Conselho Nacional de Justiça (CNJ) e os do Conselho Nacional do Ministério Público (CNMP), bem como as ações ou causas de qualquer espécie contra o CNJ e seus atos e contra o CNMP e seus atos e de suas corregedorias, ainda que tenham a União no pólo passivo 
da Constituição da República e suas hipóteses de cabimento estão previstas no art. 83 do Regimento Interno do Conselho Nacional de Justiça.

Nos casos de competência do Corregedor Nacional, cabe a ele a análise do pleito de avocação. Por outro lado, se for caso de competência do Plenário do Conselho Nacional de Justiça, designa-se relator, e o pleito é analisado pelo Plenário ${ }^{397}$.

Considerando o instituto da avocatória, também não faria sentido alçar as corregedorias e tribunais locais a instâncias obrigatórias, impedindo o julgamento, pelo Conselho Nacional de Justiça, de processos disciplinares resultantes de reclamações diretamente a ele dirigidas. Caso as corregedorias constituíssem uma espécie de "juízo natural" inafastável, nem mesmo por avocatória o julgamento poderia se dar diretamente pelo Conselho Nacional de Justiça.

O entendimento de que o Conselho Nacional de Justiça deveria examinar o comportamento ético dos magistrados apenas após pronunciamento de órgãos disciplinadores dos tribunais desfiguraria a instituição, pois ficaria à mercê dos tribunais locais, exatamente contra cuja inércia foi criado o Conselho Nacional de Justiça.

Com efeito, adotando-se a tese da subsidiariedade, o Conselho Nacional de Justiça, de órgão nacional integrante da cúpula do Poder Judiciário, passaria a ser órgão dependente de ações prévias dos Tribunais. Nesse cenário, o Conselho seria transformado em uma "corregedoria de segunda divisão"398. Com a adoção da tese da subsidiariedade, em outras palavras, a Reforma empreendida Emenda Constitucional n. 45/2004 perderia todo o seu significado. Ou pode o Conselho examinar originária e/ou concorrentemente processos de condutas dos magistrados, ou a sua manutenção perderia sentido. ${ }^{399}$

Nesse sentido, Nelson Jobim afirma que "por tudo e, em especial, da perspectiva histórica, a tese da subsidiariedade é regressista; volta, por caminhos retóricos, ao modelo 'autônomo-corporativo' ou de 'isolamento"', 400

\footnotetext{
${ }^{397}$ De acordo com o art. 79, parágrafo único do RICNJ.

${ }^{398}$ A expressão é do Ex-Conselheiro Marcelo Nobre (2011, sem paginação).

${ }^{399}$ Gandra da Silva Martins, 2011, sem paginação.

400 Jobim, 2012, sem paginação, em referência aos modelos de responsabilização judicial apontados por Cappelletti, como se estudou no item IV. 3, supra.
} 


\section{CAPÍTULO V}

\section{DIMENSÃO PROCESSUAL DA COMPETÊNCIA DISCIPLINAR DO CONSELHO NACIONAL DE JUSTIÇA}

\section{V.1. Considerações Iniciais}

No capítulo anterior, tratou-se de estudar a competência disciplinar do Conselho Nacional de Justiça sob uma perspectiva teórico-conceitual. Neste capítulo V, o enfoque da análise tem caráter mais concreto, na medida em que se volta à dimensão processual daquela competência.

Com efeito, a análise do delicado tema da competência disciplinar do Conselho Nacional de Justiça, não se pode fazer apenas de forma abstrata ${ }^{401}$. É necessário, além do tratamento teórico, o conhecimento de casos em que se discutiu a responsabilização de membros do Poder Judiciário.

É justamente por meio das diversas classes processuais previstas no Regimento Interno do Conselho Nacional de Justiça que são exercidas as competências e atribuições constitucionalmente conferidas ao órgão. Nesse sentido, ganha relevo o procedimento administrativo disciplinar, que possui fundamento mediato na Constituição da República e fundamentação imediata no Regimento Interno e em sua Resolução n. 135, de 2011.

E, uma vez que se analisa tal resolução do Conselho Nacional de Justiça, não se pode olvidar a menção ao julgamento, concluído no mês de fevereiro de 2011, da Medida Cautelar na Ação Direta de Inconstitucionalidade n. 4638, que teve por objeto, justamente, dispositivos da Resolução referida.

Ao final, a competência disciplinar do Conselho será abordada à luz de suas próprias decisões, bem como de acordo com decisões do Supremo Tribunal Federal. Complementando esta apresentação, serão apresentadas algumas sintéticas considerações acerca da relação entre o Conselho e a Suprema Corte brasileira.

${ }^{401}$ Cf. Cappelletti, 1989, p. 15. 


\section{V.2. Dos processos no âmbito do Conselho Nacional de Justiça no exercício de sua competência disciplinar}

A sistemática dos processos no âmbito do Conselho Nacional de Justiça é tratada, no Regimento Interno do Conselho (RICNJ), em título próprio.

De acordo com o art. 42 do RICNJ, os requerimentos iniciais, as reclamações disciplinares, os processos instaurados de ofício e os processos recebidos de outros órgãos ou os incidentes correlatos serão protocolados no dia da entrada, na ordem de recebimento, e registrados ${ }^{402}$ até o primeiro dia útil imediato.

Segundo o art. 44 do RICNJ, os pedidos, propostas de atos normativos e processos regularmente registrados serão, quando for o caso, apresentados à distribuição $^{403}$, a qual é feita sob a supervisão da Presidência, por sorteio, mediante sistema informatizado, por classe de processo.

É interessante indicar que não existe Conselheiro a atuar como Revisor nos processos submetidos ao CNJ - em atenção ao disposto no art. 46 do RICNJ.

Com esta apresentação feita, passemos a uma breve exposição do tratamento conferido pelo RICNJ às classes processuais mais diretamente relacionadas ao objeto do presente trabalho.

\section{V.2.1. Inspeção}

A Corregedoria Nacional de Justiça pode realizar inspeções para apuração de fatos relacionados ao conhecimento e à verificação do funcionamento dos serviços judiciais e auxiliares, das serventias e dos órgãos prestadores de serviços notariais e de

\footnotetext{
${ }^{402}$ De acordo com o art. 43 do RICNJ, o registro é realizado observadas as seguintes classes processuais: I Inspeção; II - Correição; III - Sindicância; IV - Reclamação Disciplinar; V - Processo Administrativo Disciplinar; VI - Representação por Excesso de Prazo; VII - Avocação; VIII - Revisão Disciplinar; IX Consulta; X - Procedimento de Controle Administrativo; XI - Pedido de Providências; XII - Arguição de Suspeição e Impedimento; XIII - Acompanhamento de Cumprimento de Decisão; XIV - Comissão; XV Restauração de Autos; XVI - Reclamação para Garantia das Decisões; XVII - Ato Normativo; XVIII - Nota Técnica; XIX - Termo de Compromisso; XX - Convênios e Contratos; XXI - Parecer de Mérito sobre Anteprojeto de Lei.

${ }^{403}$ Em obediência ao disposto no art. 45, a distribuição se fará entre todos os Conselheiros, inclusive os ausentes ou licenciados por até trinta dias, excetuando o Presidente e o Corregedor Nacional de Justiça.
} 
registro $^{404}$. É interessante destacar que as inspeções podem ser realizadas havendo ou não evidências de irregularidades, e independem, inclusive, de convocação ou comunicação prévia, com ou sem a presença das autoridades responsáveis pelos órgãos inspecionados. ${ }^{405}$

Merece destaque, pela relação direta que guarda com o tema deste trabalho $^{406}$, a norma contida no parágrafo único do art. 48, cujo conteúdo é o seguinte: “as inspeções poderão ser realizadas rotineiramente ou a qualquer tempo por iniciativa da Corregedoria Nacional de Justiça, por proposição de qualquer Conselheiro ou a requerimento de autoridade pública, sem prejuízo da atuação disciplinar e correcional dos respectivos Tribunais".

Para tanto, confere-se ao Corregedor Geral de Justiça, ou a ao Juiz Auxiliar do CNJ por ele designado, poderes tais como o livre ingresso em locais onde se processem atividades inspecionadas e o acesso a qualquer dado ou elemento de prova que repute relevante para os propósitos da inspeção.

O Plenário do CNJ poderá, considerando o conteúdo das atas de inspeção, em face do órgão inspecionado, regulamentar práticas administrativas, uniformizando procedimentos com vista à melhoria da organização, do funcionamento e do controle dos serviços de administração da Justiça. ${ }^{407}$

\section{V.2.2. Correição}

A Corregedoria Nacional de Justiça também é competente para realizar correições $^{408}$ para apuração de fatos determinados relacionados com deficiências graves

\footnotetext{
${ }^{404}$ RICNJ, art. 48.

${ }^{405}$ RICNJ, art. 50.

${ }^{406}$ Refere-se especificamente à análise da expressão "sem prejuízo", contida no art. 103-B da Constituição da República, vista no Capítulo anterior, acerca da natureza da competência disciplinar do CNJ.

${ }^{407}$ RICNJ, art. 53.

408 Nelson Jobim, 2012, sem paginação: "No tema de correição, há que ser feita uma distinção entre reclamações diretas e avocações. Quanto à primeira - competência do CNJ de "receber e conhecer das reclamações contra membros ou órgãos do Poder Judiciário [...], sem prejuízo da competência disciplinar e correicional dos tribunais..." - a Constituição não impõe nenhum requisito. Os interessados poderão se dirigir diretamente ao CNJ sem passar pelas corregedorias dos Tribunais. O que a Constituição afirma - e só - é que tal ação do CNJ será "sem prejuízo" das ações dos tribunais. Quanto à segunda - "avocar processos" - a Constituição é claríssima na atribuição de um poder. Como cautela, o próprio CNJ, em seu regimento interno, só admite representação para avocação, devidamente fundamentada, por parte de membro do próprio Conselho, do Procurador-Geral da República, do Presidente do Conselho Federal da OAB ou de entidade nacional da magistratura (art. 71)".
} 
dos serviços judiciais e auxiliares, das serventias e dos órgãos prestadores de serviços notariais e de registro. ${ }^{409}$

Tal como se dá relativamente às inspeções, as correições serão realizadas sem prejuízo da atuação disciplinar e correcional dos Tribunais, e são conferidos ao Corregedor Geral de Justiça, ou ao Juiz Auxiliar do CNJ por ele designado, amplos poderes instrumentais para a consecução de suas atividades correcionais ${ }^{410}$.

A correição será precedida ${ }^{411}$ de ato convocatório com indicação dos fatos a apurar e realizada na presença das autoridades responsáveis pelos órgãos correcionados, que terão direito a prestar esclarecimentos e fazer observações que reputem de interesse para a elucidação dos fatos objeto de apuração.

De acordo com o resultado das apurações realizadas em sede de correição $^{412}$, o Plenário do CNJ e o Corregedor Nacional de Justiça poderão encaminhar traslado do expediente de correição à corregedoria do Tribunal ao qual esteja o órgão correcionado vinculado, para a adoção das providências a seu cargo, com ou sem prazo.

Além disso, o Plenário do $\mathrm{CNJ}$ poderá regulamentar práticas administrativas, uniformizando procedimentos com vista à melhoria da organização, do funcionamento e do controle dos serviços de administração da Justiça.

O Plenário, a Presidência ou o Corregedor Nacional de Justiça poderá, se assim for necessário, determinar a realização de mutirão para atendimento de excesso ou congestionamento de feitos ou de processos em qualquer vara ou juízo, diretamente, ou por Juízes Auxiliares, neste caso conferindo-lhes, por delegação especial, poderes correcionais gerais para o completo desempenho das diligências ${ }^{413}$.

\footnotetext{
${ }^{409}$ RICNJ, art. 54.

${ }^{410}$ RICNJ, arts. 54 e 55.

${ }^{411}$ De acordo com o art. 56 do RICNJ, a regra geral de necessidade de prévia convocação para as atividades de correição é excepcionada em caso de extrema urgência ou em virtude de relevante motivação devidamente fundamentada, ocasião em que a correição poderá ser realizada sem a comunicação prévia e independente da ciência da autoridade judiciária responsável.

412 RICNJ, art. 57.

${ }^{413} \mathrm{Em}$ qualquer momento em que apuradas, as irregularidades que constituam ilícito penal deverão ser imediatamente comunicadas ao Ministério Público.
} 


\section{V.2.3. Sindicância}

A Corregedoria Nacional de Justiça dispõe de outro instrumento destinado a apurar irregularidades atribuídas a magistrados ou servidores nos serviços judiciais e auxiliares, ou a quaisquer serventuários, nas serventias e nos órgãos prestadores de serviços notariais e de registro, cuja apreciação não se deva dar por inspeção ou correição: trata-se da sindicância ${ }^{414}$.

De caráter residual, a sindicância é procedimento investigativo sumário, com prazo de conclusão não excedente a sessenta dias, o qual pode ser motivadamente prorrogado, por prazo certo, a juízo do Corregedor Nacional de Justiça.

O Corregedor Nacional de Justiça ou o sindicante por ele regularmente designado $^{415}$ determinará a oitiva do investigado, que poderá apresentar defesa e requerer a produção de prova no prazo de dez dias a contar da ciência da instauração da sindicância $^{416}$.

Após o encerramento da investigação, e de acordo com as informações apuradas, pode ocorrer instauração de processo disciplinar ${ }^{417}$, ou pode haver o arquivamento da sindicância ${ }^{418}$.

\section{V.2.4. Reclamação Disciplinar}

Outro instrumento de controle administrativo de que dispõe o Conselho Nacional de Justiça é a reclamação disciplinar ${ }^{419}$, a qual também é dirigida à Corregedoria Nacional de Justiça em requerimento assinado contendo a descrição do fato, a identificação do reclamado e as provas da infração.

\footnotetext{
${ }^{414}$ RICNJ, art. 60.

415 Segundo o art. 61 do RICNJ, o Corregedor Nacional de Justiça poderá delegar a Conselheiros e aos magistrados requisitados, em caráter permanente ou temporário, competência para a realização de sindicância.

${ }^{416}$ RICNJ, art. 63.

${ }^{417}$ E, de acordo com a redação pela Emenda Regimental n. 01/10, o parágrafo único do art. 63 do RICNJ, estabelece que a instauração de processo disciplinar será precedida da intimação para apresentar defesa prévia em 15 (quinze) dias

${ }^{418}$ RICNJ, art. 64.

419 Segundo o art. 67 do RICNJ, a reclamação disciplinar poderá ser proposta contra membros do Poder Judiciário e contra titulares de seus serviços auxiliares, serventias e órgãos prestadores de serviços notariais e de registro.
} 
Quando não atendidos os requisitos ou o fato narrado não configurar infração disciplinar, a reclamação será arquivada. Configurada a evidência de possível infração disciplinar atribuída a magistrado, o Corregedor Nacional de Justiça, no caso de serem suficientes as provas, proporá ao Plenário a instauração de processo administrativo disciplinar. Se, por outro lado, houver necessidade de investigação dos fatos, instaurará sindicância. ${ }^{420}$

$\mathrm{O}$ instituto da reclamação disciplinar possibilita uma importante interface entre as atividades da Corregedoria Nacional de Justiça e as atividades das corregedorias e dos Tribunais locais.

Com efeito, a Corregedoria Nacional de Justiça pode, relativamente às corregedorias e aos Tribunais locais, requisitar-lhes informações, determinar-lhes a realização de diligências instrutórias, podendo, inclusive, fixar-lhes prazo para apuração e comunicação de providências e conclusão adotadas. ${ }^{421}$

Por fim, oportuno apontar que o procedimento da reclamação disciplinar contra magistrado obedecerá, subsidiariamente, no que couber, ao disposto no Estatuto da Magistratura. ${ }^{422}$

\section{V.2.5. Processo Administrativo Disciplinar}

O processo administrativo disciplinar é o instrumento que objetiva apurar responsabilidades de magistrados e de titulares de serviços notariais e de registro por infração disciplinar praticada no exercício de suas atribuições. ${ }^{423}$

Determinada pelo Plenário do $\mathrm{CNJ}$ a instauração do processo administrativo disciplinar, o feito será distribuído a um Relator a quem competirá ordenar e dirigir a instrução respectiva. ${ }^{424}$

O processo administrativo disciplinar instaurado contra magistrado será regido pelo procedimento estabelecido no Estatuto da Magistratura, inclusive no que concerne à aplicação pelo $\mathrm{CNJ}$ das penas disciplinares respectivas, sujeitando-se

\footnotetext{
${ }^{420}$ RICNJ, art. $67, \S 2^{\circ}$ e art. 69.

${ }^{421}$ RICNJ, art. $67, \S \S 3^{\circ}$ e $4^{\circ}$ e art. 71.

${ }^{422}$ RICNJ, art. 69, parágrafo único.

${ }^{423}$ É o que estabelece o art. 73 do RICNJ, em redação dada pela Emenda Regimental n. 01/10.

${ }^{424}$ RICNJ, art. 74, com a redação conferida pela Emenda Regimental n. 01/10.
} 
subsidiariamente, no que não for incompatível à Resolução do CNJ, à Lei n. 8.112, de 1990, e à Lei n. 9.784, de $1999 .{ }^{425}$

Por se tratar de classe processual estreitamente ligada ao tema central do trabalho, um tratamento mais detalhado ao processo administrativo disciplinar será dado mais adiante. ${ }^{426}$

\section{V.2.6. Representação por excesso de prazo}

Em caso de excesso injustificado de prazo para a prática de ato da competência jurisdicional ou administrativa de magistrado, contra este poderá ser formulada representação, por qualquer pessoa com interesse legítimo, pelo Ministério Público, pelos Presidentes de Tribunais ou, ainda, de ofício pelos Conselheiros. ${ }^{427}$

Encaminhada ao Corregedor Nacional de Justiça, a representação pode ser indeferida sumariamente, ou pode-se oportunizar ao magistrado a apresentação de defesa, após a qual pode se dar o arquivamento da representação ou a instauração de processo disciplinar.

Cumpre destacar a previsão regimental que prevê a hipótese de, apurada a generalizada ocorrência de atraso ou acúmulo de processos envolvendo dois ou mais magistrados, de primeiro ou segundo grau, do mesmo órgão judiciário, a Corregedoria Nacional de Justiça pode instaurar procedimento especial para apuração concertada. ${ }^{428}$

\section{V.2.7. Avocação de processo de natureza disciplinar}

Um importante mecanismo de controle disciplinar que se confere ao Conselho Nacional de Justiça é a avocação de processo de natureza disciplinar em curso

\footnotetext{
${ }^{425}$ Segundo o art. 75 do RICNJ, com a redação dada pela Emenda Regimental n. 01/10.

${ }^{426}$ Cf. Item V.3. infra.

${ }^{427}$ RICNJ, art. 78 .

${ }^{428}$ RICNJ, art. $78, \S 5^{\circ}$, com a redação dada pela Emenda Regimental n. 01/10.
} 
contra membros do Poder Judiciário ou de seus serviços auxiliares, serventias e órgãos prestadores de serviços notariais e de registro. ${ }^{429}$

Tal avocação pode ser realizada a qualquer tempo, por meio de representação fundamentada de membro do Conselho, do Procurador-Geral da República, do Presidente do Conselho Federal da Ordem dos Advogados do Brasil ou de entidade nacional da magistratura. ${ }^{430}$

Se a matéria for de competência da Corregedoria Nacional de Justiça, o Corregedor Nacional, acolhendo o pedido, e depois de ouvido o órgão disciplinar local, com prazo de 15 dias, adotará as providências pertinentes. ${ }^{431}$

Por outro lado, se a matéria for de competência do Plenário do Conselho o Relator mandará ouvir, em quinze dias, o magistrado ou o servidor e o órgão disciplinar originariamente competente para a decisão. Decorrido tal prazo, e decidindo o Plenário pela avocação do processo disciplinar, a decisão será imediatamente comunicada ao Tribunal respectivo, para o envio dos autos no prazo máximo de quinze dias. ${ }^{432}$

Recebidos os autos avocados, estes serão novamente autuados como processo disciplinar, com distribuição por prevenção ao Relator ou encaminhados ao Corregedor Nacional, nos casos de sua competência. ${ }^{433}$

\section{V.2.8. Revisão Disciplinar}

Os processos disciplinares de juízes e membros de Tribunais julgados há menos de um ano do pedido revisional poderão ser revistos, de ofício ou mediante provocação de qualquer interessado. ${ }^{434}$

Sua instauração pode decorrer de proposição de qualquer um dos Conselheiros, do Procurador-Geral da República ou do Presidente do Conselho Federal da

\footnotetext{
${ }^{429}$ RICNJ, art. 79, modificado pela Emenda Regimental n. 01/10.

${ }^{430}$ RICNJ, art. 79, modificado pela Emenda Regimental n. 01/10.

${ }^{431}$ RICNJ, art. 80, com a redação dada pela Emenda Regimental n. 01/10.

${ }^{432}$ RICNJ, art. 81, modificado pela Emenda Regimental n. 01/10.

${ }^{433}$ RICNJ, art. 81-A, com a redação dada pela Emenda Regimental n. 01/10.

${ }^{434}$ RICNJ, art. 82. O art. 83, por sua vez, estabelece que as hipóteses de cabimento de revisão dos processos disciplinares: I - quando a decisão for contrária a texto expresso da lei, à evidência dos autos ou a ato normativo do CNJ; II - quando a decisão se fundar em depoimentos, exames ou documentos comprovadamente falsos; III - quando, após a decisão, surgirem fatos novos ou novas provas ou circunstâncias que determinem ou autorizem modificação da decisão proferida pelo órgão de origem.
} 
Ordem dos Advogados do Brasil, a qual é seguida da determinação de ofício pela maioria absoluta do Plenário do Conselho. ${ }^{435}$

Após julgado procedente o pedido de revisão, o Plenário do Conselho poderá determinar a instauração de processo administrativo disciplinar, alterar a classificação da infração, absolver ou condenar juiz ou membro de Tribunal, alterar a pena ou anular o processo. ${ }^{436}$

\section{V.2.9. Procedimento de Controle Administrativo}

Em caso de contrariedade aos princípios estabelecidos no art. 37 da Constituição da República ${ }^{437}$, os atos administrativos praticados por membros ou órgãos do Poder Judiciário poderão sofrer controle pelo Plenário do CNJ, de ofício ou mediante provocação, sem prejuízo da competência do Tribunal de Contas da União e dos Tribunais de Contas dos Estados. ${ }^{438}$

O procedimento de controle administrativo poderá ser instaurado de ofício pelo Plenário, mediante proposição de Conselheiro, do Procurador-Geral da República ou do Presidente do Conselho Federal da Ordem dos Advogados do Brasil. ${ }^{439}$

Se a autoridade que realizou o ato objeto de controle não ilidir o fundamento do pedido, o Plenário determinará: uma das seguintes providências: sustação da execução do ato impugnado; desconstituição ou revisão do respectivo ato administrativo; afastamento da autoridade competente pela prática do ato impugnado. ${ }^{440}$

Caso a matéria em exame esteja sujeita à competência administrativa concorrente, o Plenário do Conselho, por conveniência ou oportunidade, poderá determinar

\footnotetext{
${ }^{435}$ RICNJ, art. 87.

${ }^{436}$ RICNJ, art. 88.

437 Os princípios constitucionais expressos no art. 37 da Constituição são os princípios legalidade, impessoalidade, moralidade, publicidade e eficiência

${ }^{438}$ É o que estabelece o art. 91 do $\mathrm{CNJ}$, o qual traz, em seu parágrafo único, a previsão de que não será admitido o controle de atos administrativos praticados há mais de cinco (5) anos, salvo quando houver afronta direta à Constituição.

${ }^{439}$ RICNJ, art. 94.

${ }^{440}$ RICNJ, art. 95. O parágrafo único deste dispositivo possibilita ao Plenário do CNJ fixar prazos para que se adotem as providências necessárias ao exato cumprimento da lei ou dos atos do Conselho. No MS 26163- DF (Rel. Ministr Cármen Lúcia), o Supremo Tribunal Federal reafirmou que os artigos 95 e 97 do RICNJ autorizam-lhe a instaurar, de ofício, procedimento administrativo para fiscalização de atos praticados por órgãos do Poder Judiciário.
} 
que o procedimento seja iniciado ou tenha prosseguimento perante a autoridade administrativa de menor grau hierárquico para decidir, fixando prazo para a sua conclusão. $^{441}$

\section{V.2.10. Recurso Administrativo}

Embora não se trate propriamente de uma classe processual autonomamente prevista no art. 43 do RICNJ, é necessário apontar a previsão regimental que possibilita a interposição de recurso administrativo em face de algumas decisões proferidas no âmbito do Conselho Nacional de Justiça.

Com efeito, é cabível a interposição de recurso administrativo ${ }^{442}$ ao Plenário do CNJ, no prazo de cinco (5) dias contados da intimação de decisão proferida pelo Presidente do Conselho, pela Corregedoria Nacional de Justiça ou pelo Conselheiro Relator $^{443}$.

Mas há importante ressalva: são recorríveis apenas as decisões monocráticas terminativas de que manifestamente resultar ou puder resultar restrição de direito ou prerrogativa, determinação de conduta ou anulação de ato ou decisão, nos casos de processo disciplinar, reclamação disciplinar, representação por excesso de prazo, procedimento de controle administrativo ou pedido de providências.

Relatará o recurso administrativo o prolator da decisão recorrida; caso se trate de decisão proferida pelo Presidente do Conselho, o recurso poderá ser, a seu juízo, livremente distribuído. Interessante destacar que o recurso administrativo não suspende os efeitos da decisão agravada - mas o relator pode dispor em contrário, caso entenda relevante e necessário. A decisão recorrida é substituída, para todos os efeitos, pela decisão final do colegiado. ${ }^{444}$

\footnotetext{
${ }^{441}$ RICNJ, art. 96.

${ }^{442}$ Segundo o art. 115 , caput e parágrafo $1^{\circ}$, do RICNJ, com a redação dada pela Emenda Regimental $\mathrm{n}$. $01 / 2010$.

${ }^{443}$ Não cabe recurso em face dos atos e decisões do Plenário do CNJ, de acordo com o parágrafo $6^{\circ}$ do art. 115.

${ }^{444}$ RICNJ, art. 115 , parágrafos $3^{\circ}$ a $5^{\circ}$.
} 


\section{V.3. O procedimento administrativo disciplinar previsto na Resolução n. 135/2011, do Conselho Nacional de Justiça}

Para Diógenes Gasparini, dois são os fundamentos que permitem à Administração Pública instaurar um processo administrativo disciplinar: um constitucional - art. $5^{\circ}, \mathrm{LV}$ e art. 41, parágrafo $1^{\circ}$ - e um legal - art. 143, da Lei Federal n. 8.112/90. ${ }^{445}$

O objeto do processo administrativo disciplinar é a apuração de infrações e a aplicação das penas correspondentes aos servidores da Administração Pública, seus autores. Deve-se ressalvar que isso não significa que sempre deve haver uma apenação, pois pode-se chegar ao fim da instrução sem estar configurada a autoria da infração, por exemplo. A finalidade do processo administrativo disciplinar é o controle da conduta dos servidores públicos. ${ }^{446}$

A sanção disciplinar, ou pena disciplinar ${ }^{447}$, que é a pena imposta ao servidor público em resposta ao cometimento de falta funcional ou à prática de atos privados cuja repercussão leve desprestígio à Administração Pública a que pertence o servidor, tem duas funções básicas, uma preventiva e a outra repressiva. Por esta, em razão da sanção sofrida pelo servidor, busca-se restaurar o equilíbrio funcional abalado com a transgressão. Por aquela, procura-se induzir os servidores em geral a não transgredir as regras disciplinares e funcionais a que estão sujeitos. Os objetivos da sanção disciplinar são a manutenção normal e regular da função administrativa, o resguardo do prestígio que essa atividade tem para com os administrados, seus beneficiários últimos, a reeducação dos servidores e a exemplarização. ${ }^{448}$

A Resolução do Conselho Nacional de Justiça n. 135, de 13 de julho de 2011, dispõe sobre a uniformização de normas relativas ao procedimento administrativo disciplinar $(\mathrm{PAD})^{449}$ aplicável aos magistrados, acerca do rito e das penalidades, e dá outras providências.

\footnotetext{
${ }^{445}$ Gasparini, 1995, p. 572.

${ }^{446}$ Gasparini, 1995, p. 572-573.

${ }^{447}$ De acordo com o art. 3 da Resolução CNJ n. 135/2011, as penas disciplinares aplicáveis aos magistrados são: advertência, censura, remoção compulsória, disponibilidade, aposentadoria compulsória e demissão.

${ }^{448}$ Gasparini, 1995, p. 576.

449 Para uma análise acerca da necessidade de justa causa para a instauração de processo administrativo disciplinar, ver Mattos, 2004, sem paginação.
} 
É oportuno indicar as constatações que ensejaram a edição de tal Resolução, consubstanciadas em seus consideranda.

Nesse sentido, apontou-se que as normas relativas ao procedimento administrativo disciplinar dos Magistrados, não obstante tenham de observar as disposições da Constituição, do Estatuto da Magistratura, da Lei Orgânica da Magistratura, e da legislação ordinária em vigor, têm peculiaridades que caracterizam sua natureza especial. Relatou-se, também que as leis de organização judiciária dos Estados, os Regimentos dos Tribunais e Resoluções em vigor, relativas ao procedimento administrativo disciplinar aplicável aos magistrados, são discrepantes e, muitas vezes, encontram-se desatualizadas ou superadas. Registrou-se, ademais, que as disposições estatutárias devem prevalecer sobre os regramentos locais, a necessidade de sistematizar a disciplina legal em vigor acerca da matéria.

A competência para o julgamento dos processos administrativos disciplinares é do tribunal a que pertença o Magistrado, "sem prejuízo da atuação do Conselho Nacional de Justiça". ${ }^{450}$ Trata-se de norma central no âmbito não apenas da Resolução n. 135, de 2011, como de toda a sistemática do controle disciplinar que é exercido pelo Conselho.

O processo administrativo disciplinar é iniciado por determinação do Conselho, após proposta do Corregedor Nacional ou deliberação do seu Plenário, ou ainda, por determinação do Pleno ou Órgão Especial, após proposta do Corregedor - no caso de Magistrado de primeiro grau - ou proposta do Presidente do Tribunal respectivo - nos demais casos. $^{451}$

Uma vez notificado da acusação, o Magistrado terá quinze dias para apresentar defesa prévia, antes da decisão sobre a instauração do processo. Após esse prazo, o relator submeterá ao Tribunal Pleno ou ao seu Órgão Especial relatório com a proposta de instauração ou arquivamento do processo administrativo disciplinar. Em caso de instauração, o Corregedor relatará a acusação ao Órgão Censor - Magistrado de primeiro grau - ou ao Presidente do Tribunal - demais casos. ${ }^{452}$

\footnotetext{
450 Resolução CNJ n. 135/2011, art. 12, que traz, em seu parágrafo único a disposição segundo a qual os procedimentos previstos na Resolução não prejudicam demais disposições regimentais que não sejam conflitantes.

${ }^{451}$ Resolução CNJ n. 135/2011, art. 13.

452 Resolução CNJ n. 135/2011, art. 14, caput e parágrafo $1^{\circ}$.
} 
No caso da proposta de abertura de processo administrativo disciplinar ser adiada ou deixar de ser apreciada por falta de quorum, deve-se encaminhar cópia da ata da sessão respectiva à Corregedoria do Conselho, em até 15 dias, para deliberação, processamento e submissão a julgamento. ${ }^{453}$

A instauração do PAD será determinada pela maioria absoluta dos membros do Tribunal ou do respectivo Órgão Especial. O acórdão será acompanhado de portaria que conterá os fatos e o teor da acusação, assinada pelo Presidente do Órgão. Em seguida, será encaminhada para a Corregedoria do CNJ, em até 15 dias contados da sessão de julgamento, cópia da ata da sessão respectiva. Para a escolha do relator, haverá sorteio dentre os magistrados integrantes do Pleno ou do Órgão Especial, não podendo ser o magistrado que dirigiu o procedimento preparatório. O PAD deverá ser concluído em até 140 dias, prorrogáveis mediante deliberação do Plenário ou Órgão Especial, quando imprescindível para o término da instrução e por motivo justificado. ${ }^{454}$

Ao determinar a instauração do PAD, o Tribunal decidirá, também, sobre o afastamento do Magistrado do cargo, até a decisão final ou, se conveniente, por prazo determinado. $\mathrm{O}$ afastamento poderá ser decretado cautelarmente antes da instauração do PAD, quando necessário. Durante o afastamento, o Magistrado ficará impedido de utilizar o local de trabalho, bem como o veículo oficial e outras prerrogativas da função. ${ }^{455}$

O Ministério Público será intimado para manifestação no prazo de 5 dias. Logo depois o Magistrado será citado (com cópia do acórdão e da portaria que instauraram o PAD) para apresentar as razões de defesa e provas, em até cinco dias. ${ }^{456}$ Decorrido o prazo para a apresentação de defesa pelo Magistrado, o relator decidirá sobre a realização dos atos de instrução e da produção de provas requeridas ${ }^{457}$, inclusive as testemunhais, podendo determinar de ofício as que julgar necessárias. Após a instrução, o Ministério Público e o Magistrado terão dez dias para manifestação e razões finais, respectivamente.

\footnotetext{
${ }^{453}$ Resolução CNJ n. 135/2011, art. 14, parágrafo $4^{\circ}$.

${ }^{454}$ Resolução CNJ n. 135/2011, art. 14, parágrafos $5^{\circ}$ a $9^{\circ}$.

${ }^{455}$ Resolução CNJ n. 135/2011, art. 15.

${ }^{456}$ Resolução CNJ n. 135/2011, arts. 16 e 17, o qual estabelece ainda que "no caso de dois ou mais Magistrados requeridos, o prazo para defesa será comum e de 10 dias, contados da intimação do último. $\mathrm{O}$ Magistrado deve comunicar ao Relator, ao Corregedor e ao Presidente do Tribunal eventual mudança de residência. O Magistrado que estiver em local incerto ou não sabido será citado por edital, com prazo de 30 dias. O Magistrado que regularmente citado não apresentar defesa no prazo determinado será considerado revel. O relator poderá designar defensor ao Magistrado revel, concedendo-lhe igual prazo para defesa.”

457 Aplicam-se, subsidiariamente, na realização dos depoimentos das testemunhas, das acareações e das provas periciais e técnicas, as normas de legislação processual penal e da legislação processual civil, sucessivamente. A inquirição das testemunhas e o interrogatório deverão ser feitos em audiência una, ainda que em dias sucessivos, se necessário.
} 
Em atenção aos deveres de publicidade e de transparência no exercício da suas atividades, as sessões de julgamento de processo administrativo disciplinar pelo Conselho Nacional de Justiça serão públicas. Além disso, todas as decisões, inclusive as interlocutórias, deverão ser fundamentadas.

Todavia, como exceção à regra geral, tem-se que, em determinados atos processuais e de julgamento, a presença de pessoas poderá ser limitada às partes e seus advogados, ou somente a estes, desde que com esta restrição não se prejudique o interesse público. Em qualquer caso, porém, os integrantes do órgão julgador terão acesso à integralidade dos autos do processo disciplinar para o julgamento. ${ }^{458}$

Ainda com relação à publicidade e transparência do processo, determina-se que resultados dos julgamentos dos processos administrativos disciplinares sejam comunicados à Corregedoria Nacional de Justiça em até quinze dias contados da data da sessão. $^{459}$

Para a aplicação de pena ${ }^{460}$ ao Magistrado processado, são necessários os votos da maioria absoluta dos membros do Tribunal ou do Órgão Especial. Havendo divergência quanto à pena, sem que haja maioria absoluta a favor de uma delas, aplica-se a mais leve, ou, no caso de penas alternativas, a mais leve que tiver obtido o maior número de votos. ${ }^{461}$

De acordo com a gravidade da infração em exame, bem como a depender da pena aplicada ao magistrado, caberá ao Conselho Nacional de Justiça comunicar certas informações a outros órgãos. Nesse sentido, se houver indícios de cometimento de crime de ação pública incondicionada, o Presidente deve remeter cópia dos autos ao Ministério Público. E, no caso de cominação de pena de disponibilidade ou de aposentadoria compulsória, serão remetidas cópias dos autos ao Ministério Público e à Procuradoria do órgão competente ${ }^{462}$, para que sejam tomadas as providências cabíveis. ${ }^{463}$

\footnotetext{
${ }^{458}$ Resolução CNJ n. 135/2011, art. 20. Pode-se perceber que não se admite - ou não deveria se admitir - a existência de procedimento administrativo que, baseado apenas em mera conveniência voltada a tentar preservar a imagem da Magistratura e o conteúdo dos fatos, torna o processo sigiloso, privando a qualquer o conhecimento de condutas imorais que dizem respeito ao exercício da função pública.

${ }^{459}$ Resolução CNJ n. 135/2011, art. 20, parágrafo $4^{\circ}$.

${ }^{460}$ Em relação às penas de aposentadoria compulsória e de disponibilidade aplicadas pelo CNJ, José Afonso da Silva (2005, pp. 586-587) entende que a pena de aposentadoria compulsória só pode recair em magistrado que já completara o tempo para aposentar-se e não o fizera, pois antes disso a inatividade compulsória há de ser a disponibilidade.

${ }^{461}$ Resolução CNJ n. 135/2011, art. 22.

${ }^{462}$ Advocacia-Geral da União, Procuradorias dos Estados, ou Procuradorias dos Município.

${ }^{463}$ Resolução CNJ n. 135/2011, art. 22.
} 


\section{V.4. A Ação Direta de Inconstitucionalidade n. 4638-MC - análise da constitucionalidade da Resolução n. 135 CNJ}

A Associação dos Magistrados Brasileiros (AMB) ajuizou ação direta de inconstitucionalidade, autuada sob o n. 4638, pleiteando a declaração de inconstitucionalidade de diversos dispositivos contido na Resolução n. 135, de 13 de julho de 2011.

Para Maria Tereza Sadek, tal questionamento da AMB pode evidenciar "tanto o pluralismo no interior da Magistratura como a ampliação do fórum de debates":

\footnotetext{
"Tais fenômenos são auspiciosos do ponto de vista do processo de construção de uma instituição guiada por valores democráticos e republicanos. Ministros, desembargadores, juízes expuseram argumentos revelando suas posições. Divergências vieram a público explicitando princípios em confronto. As discordâncias e sua divulgação mostram quão anacrônica se tornou a figura do 'juiz boca da lei’, do juiz que não manifesta opiniões, do juiz alheio ao que se passa na sociedade. ${ }^{\$ 464}$
}

Embora tenham sido vários os dispositivos sindicados, a discussão girou, síntese, em torno de duas teses distintas.

A primeira, defendida pela $\mathrm{AMB}$, era no sentido de que a competência do Conselho Nacional de Justiça é subsidiária, ou seja, apenas é inaugurada após o esgotamento da via correcional de cada Tribunal. Para tanto, a AMB procurou valer-se do entendimento de que a expressão "sem prejuízo da competência disciplinar e correcional dos tribunais" deveria ser entendida como limitando a competência do Conselho a apenas "rever" a ação das corregedorias locais. Para a AMB, a competência da Corregedoria Nacional de Justiça seria apenas "revisional" ou "subsidiária" relativamente à atuação das corregedorias dos tribunais locais.

${ }^{464}$ Sadek, 2012, sem paginação. 
A segunda tese, defendida no âmbito da MC-ADI 4638, pela ProcuradoriaGeral da República e pela Advocacia-Geral da União, apontava para uma competência disciplinar de natureza concorrente em relação às atribuições das corregedorias locais.

No Supremo Tribunal Federal, a primeira tese foi acolhida pelo Ministro Marco Aurélio (relator do caso e autor da liminar que suspendeu, no final de dezembro, os poderes originários de investigação da instituição), consignando-se que as investigações contra magistrados devem ocorrer prioritariamente nas corregedorias dos tribunais locais.

Contudo, a maioria dos Ministros do Supremo, por seis votos a cinco ${ }^{465}$, decidiu, em 09 de fevereiro de 2012, manter os poderes de investigação do Conselho Nacional de Justiça, em decisão que manteve a autonomia do órgão para abrir investigações contra magistrados.

A Suprema Corte concluiu que o Conselho Nacional de Justiça possui poder normativo voltado a uniformizar regras que alcancem todo o Judiciário, porque se trata de Poder de caráter nacional. Frisou-se, além disso, que o poder normativo do Conselho possui como fonte primária a própria Constituição da República, e deve ser levado a efeito considerando-se as disposições constitucionais e aquelas contidas na LOMAN. ${ }^{466}$

O Supremo assentou, ainda, que, após a criação do Conselho Nacional de Justiça, esperava-se que a autonomia dos tribunais locais sofresse um novo tratamento constitucional, tendo em vista a necessidade de compatibilizá-la com as funções de controle financeiro, administrativo e disciplinar, conferidas pelo Constituinte derivado ao Conselho.

Antes de se passar aos pormenores do julgamento da ADI 4638, cumpre relacionar dois trechos específicos de votos dos Ministros com temas já estudados neste trabalho.

Nesse sentido foi a afirmação do Ministro Gilmar Mendes ao asseverar que "até as pedras sabem que as corregedorias [locais] não funcionam quando se trata de investigar seus próprios pares" coaduna-se com o entendimento apresentado no Capítulo I,

\footnotetext{
${ }^{465}$ Resolução 135/2011 do CNJ e uniformização de procedimento administrativo disciplinar: votos pela competência subsidiária (Ministros Marco Aurélio, Luiz Fux, Lewandowski, Celso de Mello e Cezar Peluso); votos pela competência concorrente (Ministros Ayres Britto, Gilmar Mendes, Joaquim Barbosa, Cármen Lúcia, Rosa Weber, Dias Toffoli).

${ }^{466}$ É importante enfatizar que este entendimento segue a jurisprudência consolidada no Supremo acerca do Conselho Nacional de Justiça, notadamente os julgamentos da ADI 3367 e ADC 12, como visto no Capítulo III deste trabalho.
} 
especificamente na parte em que se tratou do diagnóstico do Poder Judiciário no momento antes da Reforma de 2004.

Nesse diapasão, concordou o Ministro Joaquim Barbosa, afirmando que "as decisões do Conselho passaram a expor situações escabrosas no seio do Poder Judiciário nacional", e que, por esse motivo, houve "uma reação corporativa contra o órgão, que vem produzindo resultados importantíssimos no sentido de correção das mazelas”.

Esmiuçando os argumentos trazidos aos autos da ADI 4638 pela Procuradoria-Geral da República, é necessário ponderar, inicialmente, que foi levantada preliminar ao mérito, tendo em vista que, na hipótese de declaração de inconstitucionalidade formal da Resolução n. 135/2011, haveria a repristinação de norma anterior que a resolução revogou, a Resolução n. 30, de 7 de março de 2007, a qual disciplinava a matéria de modo similar. ${ }^{467}$

Tal preliminar foi rejeitada, pois, tendo em vista a revogação da Resolução n. 30, de 2007, pela Resolução n. 135/2011, restaria inviável a análise em âmbito de controle concentrado de constitucionalidade. Ademais, salientou-se que haveria círculo vicioso caso se entendesse pela necessidade de se impugnar a resolução pretérita juntamente com a que estivesse diretamente sob apreciação.

Passando ao mérito da questão, a Procuradoria-Geral da República destacou que a Emenda Constitucional n. 45 trouxe grande inovação à organização constitucional do Poder Judiciário brasileiro ao criar o Conselho Nacional de Justiça, o que leva a uma mudança até mesmo dos padrões hermenêuticos relativos ao Poder Judiciário: "não se deve buscar interpretar a destinação constitucional e as competências do Conselho Nacional de Justiça com os padrões hermenêuticos anteriores à Emenda Constitucional n. 45/2004, como no que diz respeito ao alcance da autonomia dos tribunais", 468

Segundo a Procuradoria-Geral da República, a partir da instalação do Conselho Nacional de Justiça, os tribunais mantiveram sua autonomia administrativa, mas relativizada pelas competências do Conselho. Conforme explicou, impõe-se adotar interpretação sistemática entre a norma de autonomia do artigo 96 da Constituição Federal

\footnotetext{
${ }^{467}$ Desta forma, o procurador-geral entende que fica prejudicado o conhecimento da ação no que se refere à tese de inconstitucionalidade formal do diploma questionado, como prejudicadas as impugnações específicas apresentadas com base nesse fundamento e aquelas referentes a dispositivos que apenas reproduzem normas da Resolução n. 30, de 2007.

${ }^{468}$ Informativo Mensal de Jurisprudência do STF n. 16, Fevereiro de 2012 - "Resolução n. 135/2011 do CNJ e uniformização de procedimento administrativo disciplinar".
} 
e os dispositivos da Emenda Constitucional n. 45/2004, que preveem as competências constitucionais do Conselho Nacional de Justiça. Para a Procuradoria-Geral da República, é inadequado contrapor a todo instante a Resolução n. 135/2011 às normas da LOMAN. Afinal, esta Lei Complementar obviamente não cogitava do Conselho Nacional de Justiça, criado 25 anos depois da edição daquela lei complementar. "À luz da LOMAN, o próprio Conselho Nacional de Justiça e todos os seus atos serão inválidos". 469

É importante destacar também que a Resolução n. 135/2011, ainda de acordo com o Parecer da Procuradoria-Geral da República, possui duplo fundamento constitucional de validade. No que se refere ao conteúdo que disciplina o rito do processo administrativo disciplinar no próprio Conselho Nacional de Justiça, o fundamento está expresso no artigo $5^{\circ}$, parágrafo $2^{\circ}$, da Emenda Constitucional n. 45/2004; em relação ao rito dos processos administrativos disciplinares nos demais órgãos do Poder Judiciário, a competência do Conselho Nacional de Justiça e a consequente validade da Resolução n. 135, de 2011, decorre da competência constitucional daquele órgão para exercer o controle da atuação administrativa dos tribunais na forma do artigo 103, b, parágrafo $4^{\mathrm{o}}$ da Constituição, na redação da Emenda Constitucional n. 45/2004.

O Procurador-Geral da República, Dr. Roberto Gurgel, enfatizou, ademais, que considerada a premissa de que o Poder Judiciário tem caráter nacional e regime orgânico unitário, é conveniente do ponto de vista jurídico, administrativo, finalístico e materialmente constitucional a iniciativa do Conselho Nacional de Justiça de uniformizar o processo administrativo disciplinar dos magistrados por meio da Resolução n. 135/2011. Nesse sentido, ponderou que "seria justamente contrário a esse regime que, em nome da autonomia das cortes de justiça, persistisse a multiplicidade de ritos e normas disciplinares nos diferentes tribunais". ${ }^{470}$

Registrou-se, outrossim, que a aprovação da Resolução n. 135/2011 pelo plenário do conselho foi precedida de consulta a todos os tribunais do país e às maiores associações nacionais de juízes, com a finalidade de ouvi-los e colher sugestões para o aperfeiçoamento do sistema disciplinar dos magistrados. E acrescentou-se que a resolução amplia diversos mecanismos para a garantia da defesa dos magistrados investigados, não

\footnotetext{
${ }^{469}$ Informativo Mensal de Jurisprudência do STF n. 16, Fevereiro de 2012 - "Resolução n. 135/2011 do CNJ e uniformização de procedimento administrativo disciplinar".

${ }^{470}$ Informativo Mensal de Jurisprudência do STF n. 16, Fevereiro de 2012 - "Resolução n. 135/2011 do CNJ e uniformização de procedimento administrativo disciplinar".
} 
havendo, portanto, nenhuma ideia pré-concebida no sentido de desrespeitar ou aviltar a magistratura nacional. ${ }^{471}$

Tal como defendido no Capítulo I deste trabalho, a Procuradoria-Geral da República procurou demonstrar o que foi que levou à criação de um órgão de controle da Magistratura: "certamente, a percepção generalizada da insuficiência dos órgãos de controle interno para tal mister ou, em outras palavras, o notório déficit de atuação das corregedorias locais". ${ }^{472}$

O Procurador-Geral da República lembrou ainda que não há previsão de subsidiariedade da competência disciplinar do Conselho Nacional de Justiça na Emenda Constitucional n. 45/2004, mas, ao contrário, mais de um dispositivo de seu texto aponta para a natureza concorrente das competências. Ele citou o artigo 103, b, parágrafo $4^{\mathrm{o}}$, inciso 3, que prevê competência para conhecer reclamações contra juízes e outros servidores do Poder Judiciário, sem prejuízo da competência disciplinar dos tribunais. "Se é sem prejuízo, há competências concorrentes, não subsidiárias”, afirmou.

Segundo o Procurador-Geral da República, uma das colunas de sustentação desse novo sistema de controle instituído pela Emenda Constitucional n. 45/2004 é exatamente o poder de iniciativa própria dos conselhos, notadamente por meio de suas corregedorias nacionais de forma concorrente com o das corregedorias locais. "Subordinar a atuação do Conselho Nacional de Justiça e do CNMP à atuação das corregedorias locais" seria “incongruente em face da própria razão de existir do órgão e das suas próprias atribuições constitucionais". 473

Apresentados os argumentos colacionados pela Procuradoria-Geral da República no julgamento da ADI 4638-MC, passa-se à abordagem do entendimento do Supremo acerca de cada um dos dispositivos da Resolução n. 135/2011 em face da Constituição.

Iniciado o julgamento de referendo em medida cautelar em ação direta de inconstitucionalidade, o Ministro Marco Aurélio, Relator, em breve introdução, destacou que caberia à Corte definir se o Conselho Nacional de Justiça, ao editar a resolução em

\footnotetext{
${ }^{471}$ Informativo Mensal de Jurisprudência do STF n. 16, Fevereiro de 2012 - "Resolução n. 135/2011 do CNJ e uniformização de procedimento administrativo disciplinar".

472 Informativo Mensal de Jurisprudência do STF n. 16, Fevereiro de 2012 - "Resolução n. 135/2011 do CNJ e uniformização de procedimento administrativo disciplinar".

${ }^{473}$ Informativo Mensal de Jurisprudência do STF n. 16, Fevereiro de 2012 - "Resolução n. 135/2011 do CNJ e uniformização de procedimento administrativo disciplinar".
} 
comento, teria extrapolado os limites a ele conferidos pela Constituição. Assinalou que as competências atribuídas, pela Emenda Constitucional n. 45, de 2004, ao referido órgão produziriam tensão entre a sua atuação ( $\mathrm{CF}$, art. 103-B, $\S 4^{\circ}$, III) e a autonomia dos tribunais (CF, artigos 96, I, a, e 99). Após, o Tribunal deliberou pela análise de cada um dos dispositivos da norma questionada ${ }^{474}$.

Quanto ao art. $2^{0475}$, o Supremo Tribunal Federal, por maioria, referendou o indeferimento da liminar. Consignou-se que o Conselho Nacional de Justiça integraria a estrutura do Poder Judiciário, mas não seria órgão jurisdicional e não interviria na atividade judicante. Este Conselho possuiria, à primeira vista, caráter eminentemente administrativo e não disporia de competência para, mediante atuação colegiada ou monocrática, reexaminar atos de conteúdo jurisdicional, formalizados por magistrados ou tribunais do país. Ressaltou-se que a escolha pelo constituinte derivado do termo "Conselho" para a instituição interna de controle do Poder Judiciário mostrar-se-ia eloquente para evidenciar a natureza administrativa do órgão e para definir, de maneira precisa, os limites de sua atuação. Sublinhou-se que o vocábulo "Tribunal” contido no art. $2^{\circ}$ em tela revelaria tão somente que as normas seriam aplicáveis também ao Conselho Nacional de Justiça e ao Conselho da Justiça Federal. ${ }^{476}$

Em relação ao art. $3^{\circ}, \mathrm{V}$, da Resolução ${ }^{477}$, referendou-se o indeferimento da liminar. Repeliu-se a alegação de que o preceito impugnado excluiria o direito ao recebimento dos vencimentos proporcionais em caso de aposentadoria compulsória. Considerou-se que, no silêncio deste dispositivo - que arrola a aposentadoria compulsória sem referência à percepção de subsídios ou proventos proporcionais —, não se poderia

\footnotetext{
${ }^{474}$ No Anexo I, ao final do trabalho, disponibiliza-se, um quadro-resumo esquemático com a indicação, um a um, dos dispositivos analisados na ADI 4638, bem como o respectivo julgamento acerca de sua constitucionalidade, tanto pelo Ministro Marco Aurélio, Relator, como pelo Plenário do Supremo Tribunal Federal.

${ }^{475}$ Resolução n. 135, de 2011, Art. 2. "Considera-se Tribunal, para os efeitos desta resolução, o Conselho Nacional de Justiça, o Tribunal Pleno ou o Órgão Especial, onde houver, e o Conselho da Justiça Federal, no âmbito da respectiva competência administrativa definida na Constituição e nas leis próprias".

${ }^{476} \mathrm{O}$ Ministro Ayres Britto ressalvou que o CNJ seria mais do que um órgão meramente administrativo, pois abrangeria o caráter hibridamente político e administrativo de natureza governativa. Ficaram Vencidos os Ministros Luiz Fux e Cezar Peluso, Presidente, que também referendavam o indeferimento da liminar, mas davam ao preceito interpretação conforme a Constituição. O primeiro o fazia, sem redução de texto, para esclarecer que a expressão "Tribunal" alcançaria o CNJ apenas para efeito de submissão deste órgão às regras da resolução. O Presidente afirmava que os tribunais só poderiam ser abarcados pelos efeitos da resolução que caberiam no âmbito de incidência do poder normativo transitório do CNJ e não atingidos por normas incompatíveis com a autonomia que os próprios tribunais têm de se autorregularem nos termos da Constituição.

${ }^{477}$ Art. $3^{\circ}$ São penas disciplinares aplicáveis aos magistrados da Justiça Federal, da Justiça do Trabalho, da Justiça Eleitoral, da Justiça Militar, da Justiça dos Estados e do Distrito Federal e Territórios: ... V aposentadoria compulsória
} 
presumir que o Conselho Nacional de Justiça — órgão sancionador — atuasse à revelia do art. 103-B, $\S 4^{\circ}$, III, da $\mathrm{CF}$, preceito que determinaria expressamente aposentadoria compulsória com subsídios ou proventos proporcionais ao tempo de serviço. Registrou-se que a declaração de inconstitucionalidade do art. $3^{\circ}, \mathrm{V}$, da resolução em comento pressuporia conflito manifesto com norma constitucional, inexistente na espécie e, por isso, deveria ser mantida a sua eficácia.

Já em relação ao $\S 1^{\circ}$ desse mesmo artigo ${ }^{478}$ foi referendado, por maioria, o deferimento da liminar. Elucidou-se que, embora os magistrados respondessem disciplinarmente por ato caracterizador de abuso de autoridade, a eles não se aplicariam as penas administrativas versadas na Lei n. 4898/65, porquanto submetidos à disciplina especial derrogatória, qual seja, a Lei Orgânica da Magistratura Nacional. Enfatizou-se que esta estabeleceria, em preceitos exaustivos, os deveres e as penalidades impostos aos juízes. $^{479}$

No tocante ao art. $4^{\mathrm{o}^{480}}$, referendou-se, por maioria, o indeferimento da liminar. Afastou-se a assertiva de que a supressão da exigência de sigilo na imposição das sanções de advertência e censura deveriam ser aplicadas nos moldes preconizados na LOMAN. $^{481}$

\footnotetext{
478 "As penas previstas no art. $6^{\circ}, \S 1^{\circ}$, da Lei n. 4.898, de 9 de dezembro de 1965 , são aplicáveis aos magistrados, desde que não incompatíveis com a Lei Complementar n. 35, de 1979"

${ }^{479} \mathrm{O}$ Ministro Celso de Mello observou que o regime jurídico definido pela LOMAN, posto sob reserva de lei complementar, não permitiria que o $\mathrm{CNJ}$, ao atuar em sede administrativa, formulasse resolução ampliativa do rol a que se refere o art. 42 do Estatuto da Magistratura. Vencidos os Ministros Cármen Lúcia e Joaquim Barbosa, que indeferiam a cautelar. A primeira, ao fundamento de que preveleceria, em exame precário, a presunção de constitucionalidade das leis, haja vista que o art. 103-B, § $4^{\circ}$, IV, da CF estabeleceria a competência do CNJ para representar ao Ministério Público no caso de crime contra a Administração Pública ou de abuso de autoridade e que este instituto seria disciplinado pela Lei 4.898/65, ao passo que a LOMAN não trataria especificamente do tema. O último, por reputar que retirar a eficácia da norma, neste momento e pelo tempo que perdurar a cautelar, significava criar excepcionalidade injustificada aos magistrados.

480 "O magistrado negligente, no cumprimento dos deveres do cargo, está sujeito à pena de advertência. Na reiteração e nos casos de procedimento incorreto, a pena será de censura, caso a infração não justificar punição mais grave".

${ }^{481}$ Vencidos os Ministros Luiz Fux e o Presidente Ministro Cezar Peluso. Aquele reputava existir uma contraposição entre a resolução e o Estatuto da Magistratura, o qual, a exemplo de outras leis federais, também preveria o sigilo na tutela de seus membros. Ademais, assinalava que na ponderação de valores, consoante moderna doutrina, o princípio da dignidade da pessoa humana prevaleceria sobre o interesse público. O Presidente, por sua vez, destacava que aqueles ligados, de algum modo, ao sistema jurídico e Judiciário não deveriam ter penas e processos disciplinares em segredo. Não obstante, enfatizava que se a própria Constituição admitiria o regime de publicidade restrita aos processos criminais, em que a pena seria mais grave, indagava a razão de não admiti-la quanto à pena considerada mais leve.
} 
Estreitamente ligado ao art. $4^{\circ}$ é o art. $20^{482}$, em relação ao qual se referendou o indeferimento da cautelar. Ressaltou-se que o sigilo imposto com o objetivo de proteger a honra dos magistrados contribuiria para um ambiente de suspeição e não para a credibilidade da magistratura, pois nada mais conducente à aquisição de confiança do povo do que a transparência e a força do melhor argumento. Nesse sentido, assentou-se que a LOMAN, ao determinar a imposição de penas em caráter sigiloso, ficara suplantada pela Constituição. Asseverou-se que a modificação trazida no art. 93, IX e X, da CF pela Emenda Constitucional n. 45/2004 assegurara a observância do princípio da publicidade no exercício da atividade judiciária, inclusive nos processos disciplinares instaurados contra juízes, permitindo-se, entretanto, a realização de sessões reservadas em casos de garantia ao direito à intimidade, mediante fundamentação específica. Por fim, explicitou-se que, ante o novo contexto, a resolução do Conselho Nacional de Justiça, ao prever a publicidade das sanções disciplinares e da sessão de julgamento não extrapolara os limites normativos nem ofendera garantia da magistratura, pois, a rigor, essas normas decorreriam diretamente da Constituição, sobretudo, posteriormente à edição da Emenda Constitucional n. 45/2004.

Na sequência, o Plenário atribuiu interpretação conforme a Constituição aos artigos $8^{\circ}$ e $9^{\circ}, \S \S 2^{\circ}$ e $3^{\circ}$ da Resolução n. $135 / 2011^{483}$, com o fim de que, onde constasse "Presidente" ou "Corregedor", fosse lido "órgão competente do tribunal". O Relator realçou que o Conselho Nacional de Justiça poderia exigir informações acerca do andamento de processos disciplinares em curso nos tribunais, mas não caberia ao órgão definir quem seria a autoridade responsável pelo envio dos dados, sob pena de contrariedade aos artigos 96, I, e 99 da CF. O Ministro Ayres Britto acresceu que o fundamento de validade das competências tanto do Conselho Nacional de Justiça quanto

482 “O julgamento do processo administrativo disciplinar será realizado em sessão pública e serão fundamentadas todas as decisões, inclusive as interlocutórias".

483 "Art. $8^{\circ} \mathrm{O}$ Corregedor, no caso de magistrados de primeiro grau, o Presidente ou outro membro competente do Tribunal, nos demais casos, quando tiver ciência de irregularidade, é obrigado a promover a apuração imediata dos fatos, observados os termos desta Resolução e, no que não conflitar com esta, do Regimento Interno respectivo. Parágrafo único. Se da apuração em qualquer procedimento ou processo administrativo resultar a verificação de falta ou infração atribuída a magistrado, será determinada, pela autoridade competente, a instauração de sindicância ou proposta, diretamente, ao Tribunal, a instauração de processo administrativo disciplinar, observado, neste caso, o art. 14, caput, desta Resolução. Art. $9^{\circ}$ A notícia de irregularidade praticada por magistrados poderá ser feita por toda e qualquer pessoa, exigindo-se formulação por escrito, com confirmação da autenticidade, a identificação e o endereço do denunciante. $\S 1^{\circ}$ Identificados os fatos, o magistrado será notificado a fim de, no prazo de cinco dias, prestar informações. $\S 2^{\circ}$ Quando o fato narrado não configurar infração disciplinar ou ilícito penal, o procedimento será arquivado de plano pelo Corregedor, no caso de magistrados de primeiro grau, ou pelo Presidente do Tribunal, nos demais casos ou, ainda, pelo Corregedor Nacional de Justiça, nos casos levados ao seu exame. $\S 3^{\circ}$ Os Corregedores locais, nos casos de magistrado de primeiro grau, e os presidentes de Tribunais, nos casos de magistrados de segundo grau, comunicarão à Corregedoria Nacional de Justiça, no prazo de quinze dias da decisão, o arquivamento dos procedimentos prévios de apuração contra magistrados”), 
dos tribunais seria a Constituição. Afirmou que, consoante o $\S 4^{\circ}$ do art. 103-B da CF, o Conselho Nacional de Justiça desempenharia função de controle, cuja acepção compreender-se-ia em dois sentidos: o de prevenção e o de correição.

Ato contínuo, em juízo meramente delibatório, o Supremo, por maioria, conferiu interpretação conforme a Constituição ao art. 10 da Resolução ${ }^{484}$ para, excluindo a expressão "por parte do autor da representação", entender-se que o sentido da norma seria o da possibilidade de recurso pelo interessado, seja ele o magistrado contra o qual se instaura o procedimento, seja ele o autor da representação arquivada. Enfatizou-se inexistirem, no sistema de direito público brasileiro, especialmente no Judiciário, decisões terminais no âmbito de colegiados por parte de individualidades, componentes do tribunal. Portanto, seria uma decorrência natural que houvesse um recurso para o colegiado. ${ }^{485}$

No que se refere ao art. 12, caput e parágrafo único, da Resolução 135/2011 $1^{486}$, o Plenário, por maioria, negou referendo à liminar e manteve a competência originária e concorrente do referido órgão para instaurar procedimentos administrativos disciplinares aplicáveis a magistrados.

Para o Ministro Joaquim Barbosa, a Emenda Constitucional n. 45/2004, ao criar o Conselho Nacional de Justiça, não se limitara a criar mais um órgão para exercer, concomitantemente, atribuições exercidas com deficiência por outros órgãos. A referida emenda teria requalificado, de maneira substantiva, uma dada função, ao atribuir ao novo órgão posição de proeminência em relação aos demais. Explicou que essa primazia decorreria, em primeiro lugar, do fato de que a própria Constituição teria concedido ao Conselho Nacional de Justiça extraordinário poder de avocar processos disciplinares em curso nas corregedorias dos tribunais. Aduziu não se conferir poder meramente subsidiário a órgão hierarquicamente superior, que teria a prerrogativa de tomar para si decisões que,

\footnotetext{
484 "Das decisões referidas nos artigos anteriores caberá recurso no prazo de 15 (quinze) dias ao Tribunal, por parte do autor da representação"

${ }^{485}$ Vencidos o relator e os Ministros Luiz Fux, Ricardo Lewandowski e Celso de Mello, que mantinham a cautelar conforme deferida, ou seja, em maior extensão. Vislumbravam que não seria dado ao Conselho criar recursos contra decisões administrativo-disciplinares de tribunais tomadas em procedimento reservado à normatização do legislador complementar ou deles próprios, a depender da sanção aplicável. Vencida, também, a Ministra Rosa Weber, que indeferia o pedido da AMB, por reputar, em cognição sumária, inserirse na competência transitória do CNJ, em virtude da redação da Emenda Constitucional n. 45/2004/2004, a possibilidade de regrar e, inclusive, prever o mencionado recurso no âmbito de todos os tribunais.

486 ("Art. 12. Para os processos administrativos disciplinares e para a aplicação de quaisquer penalidades previstas em lei, é competente o Tribunal a que pertença ou esteja subordinado o Magistrado, sem prejuízo da atuação do Conselho Nacional de Justiça. Parágrafo único. Os procedimentos e normas previstos nesta Resolução aplicam-se ao processo disciplinar para apuração de infrações administrativas praticadas pelos Magistrados, sem prejuízo das disposições regimentais respectivas que com elas não conflitarem”)
} 
em princípio, deveriam ser tomadas por órgãos hierarquicamente inferiores. Em segundo lugar, destacou que o aludido órgão superior teria o poder de agir de ofício, em campo de atuação em princípio demarcado para a atividade de órgão inferior, de modo que jamais se poderia entender que a competência daquele seria subsidiária, salvo sob mandamento normativo expresso. Reforçou que a Emenda Constitucional n. 45/2004 nunca aventara a hipótese da subalternidade da ação disciplinar do Conselho Nacional de Justiça em relação às corregedorias. ${ }^{487}$

A Ministra Rosa Weber acrescentou que o Conselho deteria competência para expedir normas de caráter genérico e abstrato sobre as matérias do art. 103-B, I, II e $\S$ $4^{\mathrm{o}}$, da $\mathrm{CF}$, de sorte a não se falar em usurpação da competência dos tribunais ou do legislador complementar. Entreviu que, enquanto não vigente o novo Estatuto da Magistratura, caberia ao Conselho Nacional de Justiça disciplinar, mediante resoluções, as matérias de sua competência. Assim, o referido órgão poderia regulamentar matérias até então sediadas na LOMAN e nos regimentos internos dos tribunais nos processos disciplinares que tramitassem no âmbito dessas Cortes, diante do redesenho institucional promovido pela Emenda Constitucional n. 45/2004. Considerou que a uniformização das regras pertinentes aos procedimentos administrativos disciplinares aplicáveis aos magistrados apresentar-se-ia como condição necessária à plena efetividade da missão institucional do Conselho Nacional de Justiça. Consignou, nesse sentido, o caráter uno do Judiciário, a legitimar a existência de um regramento minimamente uniforme na matéria. Concluiu, com base no art. 103-B, $\S 4^{\mathrm{o}}$, I, II, III e V, da CF, que a competência do Conselho na matéria seria originária e concorrente, e não meramente subsidiária. ${ }^{488}$

O Ministro Dias Toffoli sublinhou que o Conselho Nacional de Justiça não teria sido criado para substituir as corregedorias, mas deveria trazer à luz da nação os casos mais relevantes, bem como decidir quais processos deveriam permanecer nos tribunais locais. Enfatizou-se que se estaria a defender a possibilidade de ampliação da atividade do Conselho Nacional de Justiça, sem, entretanto, retirar a autonomia dos tribunais. Discorreu, em obter dictum, sobre a inadmissibilidade de o Conselho Nacional de Justiça interferir nos trabalhos da justiça eleitoral.

\footnotetext{
${ }^{487}$ Informativo Mensal de Jurisprudência do STF n. 16, Fevereiro de 2012 - "Resolução n. 135/2011 do CNJ e uniformização de procedimento administrativo disciplinar".

${ }^{488}$ Informativo Mensal de Jurisprudência do STF n. 16, Fevereiro de 2012 - "Resolução n. 135/2011 do CNJ e uniformização de procedimento administrativo disciplinar".
} 
A Ministra Cármen Lúcia salientou a necessidade de o órgão exercer sua competência primária e concorrente sem necessidade de formalidades além das dispostas constitucionalmente.

Sob esse aspecto, o Ministro Gilmar Mendes asseverou que condicionar a atividade do Conselho Nacional de Justiça a uma formalização, no sentido de obrigá-lo a motivar a evocação de sua competência disciplinar no caso concreto, importaria na impugnação sistêmica de seus atos. Enfatizou ser truísmo que a atividade correcional não seria efetiva, especialmente nas ações do próprio tribunal. Rememorou que a resolução questionada teria sido obra do Conselho Nacional de Justiça em conjunto com os tribunais, ao perceberem incongruências, perplexidades e insegurança nas suas próprias disciplinas. Foi enfatizado que o Conselho Nacional de Justiça não poderia escolher, de forma aleatória, os processos que devesse julgar, sob pena de se fulminar o princípio da impessoalidade. Assim, a expressão "sem prejuízo da atuação do Conselho Nacional de Justiça” observaria a regra da competência do tribunal a que pertencesse ou estivesse subordinado o magistrado, e a possibilidade de atuação do Conselho Nacional de Justiça dar-se-ia, nos moldes da Constituição, mediante situação anômala. ${ }^{489}$

O Ministro Luiz Fux frisava que estabelecer ao Conselho Nacional de Justiça, em casos motivados e em situações anômalas, competência administrativa comum seria adaptar a realidade normativa à realidade prática. Lembrava que, atualmente, o próprio órgão já ponderaria o que seria essencial ao exercício de suas atribuições e o que deveria se sujeitar às corregedorias locais.

O Ministro Ricardo Lewandowski explicitou, com base nos princípios federativo, republicano e democrático, bem como no princípio da autonomia dos tribunais, que a competência correcional do Conselho Nacional de Justiça seria de natureza material

\footnotetext{
${ }^{489}$ Informativo Mensal de Jurisprudência do STF n. 16, Fevereiro de 2012 - "Resolução n. 135/2011 do CNJ e uniformização de procedimento administrativo disciplinar". Vencidos o relator e os Ministros Luiz Fux, Ricardo Lewandowski, Celso de Mello e Presidente, que referendavam a liminar, para exigir que o Conselho Nacional de Justiça, ao evocar sua competência correcional, fizesse-o mediante motivação. O relator aduzia que a Constituição, ao delimitar a atuação do Conselho Nacional de Justiça no tocante à matéria, estabelecera que lhe competiria o controle das atividades administrativa e financeira do Judiciário, bem como dos deveres funcionais dos juízes. Caber-lhe-ia, também, o zelo pela autonomia desse Poder e pela observância do art. 37 da CF. Poderia, assim, desconstituir atos, revê-los ou fixar prazo para que se adotassem providências necessárias ao exato cumprimento da lei. Afirmava, ademais, competir-lhe receber e conhecer de reclamações contra membros ou órgãos do Judiciário e contra seus próprios serviços, sem prejuízo da atribuição disciplinar e correcional dos tribunais, podendo avocar processos disciplinares em curso, mediante motivação socialmente aceitável — hipóteses de inércia, simulação na investigação, procrastinação ou ausência de independência do tribunal de origem. Cumprir-lhe-ia, igualmente, rever, de ofício ou mediante provocação, os processos disciplinares de juízes e membros de tribunais julgados há menos de 1 ano, nos termos da primeira parte do art. 12 da Resolução n. 135, de 2011.
} 
ou administrativa comum, nos termos do art. 23, I, da CF, assim como a desempenhada pelas corregedorias dos tribunais, cujo exercício dependeria de decisão motivada apta a afastar a competência disciplinar destes, em situações excepcionais. ${ }^{490}$

O Ministro Celso de Mello mencionou que reduzir ou mitigar a autonomia dos tribunais locais significaria degradar a autonomia institucional dos Estados-membros, e observava a importância da preservação da integridade das garantias dos juízes, mecanismos de proteção dos próprios cidadãos. Nessa contextura, o Conselho Nacional de Justiça deveria se pautar pelo princípio da subsidiariedade, e interpretação contrária colocaria em jogo a própria funcionalidade do órgão.

O Presidente do Supremo, Ministro Cezar Peluso apontou que um dos fatores que teriam ditado a edição da Emenda Constitucional n. 45/2004 seria a relativa deficiência dos órgãos correcionais especialmente tribunais. Nesse sentido, o Conselho Nacional de Justiça não teria sido criado para extinguir as corregedorias, mas para remediar sua inoperância. Consignava que qualquer interpretação que pusesse em risco a sobrevivência prática das corregedorias envolveria uma contradição no modo de conceber a Emenda Constitucional n. 45/2004 e a função do Conselho Nacional de Justiça. Haveria, portanto, a necessidade de compatibilizar a concepção da competência do órgão com a necessidade de não prejudicar, como determinaria a Constituição, a competência das corregedorias. Isso porque reconhecer a competência primária do Conselho Nacional de Justiça sem motivação implicaria reduzir um grau de jurisdição administrativa para os magistrados. Por fim, deliberou-se suspender o julgamento.

No segundo dia de julgamento, negou-se, por maioria, referendo à cautelar quanto aos $\S \S 3^{\circ}, 7^{\circ}, 8^{\circ}$ e $9^{\circ}$ do caput do art. 14; aos incisos IV e V do caput do art. 17; e ao $\S 3^{\circ}$ do art. 20 do ato questionado. ${ }^{491}$

\footnotetext{
${ }^{490}$ Informativo Mensal de Jurisprudência do STF n. 16, Fevereiro de 2012 - "Resolução n. 135/2011 do CNJ e uniformização de procedimento administrativo disciplinar".

491 “Art. 14. Antes da decisão sobre a instauração do processo pelo colegiado respectivo, a autoridade responsável pela acusação concederá ao magistrado prazo de quinze dias para a defesa prévia, contado da data da entrega da cópia do teor da acusação e das provas existentes (...) $\S 3^{\circ} \mathrm{O}$ Presidente e o Corregedor terão direito a voto $\ldots \S 7^{\circ} \mathrm{O}$ relator será sorteado dentre os magistrados que integram o Pleno ou o Órgão Especial do Tribunal, não havendo revisor. $\S 8^{\circ}$ Não poderá ser relator o magistrado que dirigiu o procedimento preparatório, ainda que não seja mais o Corregedor. $\S 9^{\circ}$. O processo administrativo terá o prazo de cento e quarenta dias para ser concluído, prorrogável, quando imprescindível para o término da instrução e houver motivo justificado, mediante deliberação do Plenário ou Órgão Especial ... Art. 17 Após, o Relator determinará a citação do Magistrado para apresentar as razões de defesa e as provas que entender necessárias, em 5 dias, encaminhando-lhe cópia do acórdão que ordenou a instauração do processo administrativo disciplinar, com a respectiva portaria, observando-se que: ... IV - considerar-se-á revel o magistrado que, regularmente citado, não apresentar defesa no prazo assinado; V - declarada a revelia, o
} 
A Ministra Rosa Weber reiterou que o redesenho do Poder Judiciário promovido pela Emenda Constitucional n. 45/2004 imporia releitura sistemática das normas constitucionais e infraconstitucionais relativas ao controle do Judiciário, inclusive a Lei Orgânica da Magistratura Nacional - LOMAN, à luz do novo paradigma instituído a partir da criação do Conselho Nacional de Justiça. Assim, tendo em conta a regra de transição do art. $5^{\circ}, \S 2^{\circ}$, da referida emenda, a qual embasaria a Resolução n. 135/2011, asseverou que, enquanto não editado o Estatuto da Magistratura, a uniformização das regras referentes aos procedimentos administrativos disciplinares aplicáveis aos juízes representaria condição essencial à plena efetividade da missão institucional do Conselho. $^{492}$

O Ministro Ayres Britto destacou que esse órgão seria um aparato do Poder Judiciário situado na cúpula da organização judiciária do país, a conferir peculiaridade federativa ao aludido Poder. Além disso, exerceria quarta função estatal, a saber, a de controle preventivo, profilático e corretivo. Consignou, ainda, que o art. 96, I, a, da CF referir-se-ia a norma geral para todo e qualquer processo, ao passo que o art. 14 da resolução impugnada seria de cunho especial, de âmbito peculiarmente disciplinar. Frisou que o controle entregue, pela Emenda Constitucional n. 45/22004, aos cuidados do Conselho Nacional de Justiça exigiria interpretação sistemática, para que esse órgão administrativo não se opusesse aos tribunais.

O Ministro Gilmar Mendes reputou que o preceito apenas estabeleceria modelo correcional pertencente ao Conselho Nacional de Justiça como órgão de cúpula, sem que houvesse comprometimento do modelo federativo ou da autonomia do Judiciário. $^{493}$

relator poderá designar defensor dativo ao requerido, concedendo-lhe igual prazo para a apresentação de defesa ... Art. $20 \ldots \S 3^{\circ} \mathrm{O}$ Presidente e o Corregedor terão direito a voto").

${ }^{492}$ Informativo Mensal de Jurisprudência do STF n. 16, Fevereiro de 2012 - "Resolução n. 135/2011 do CNJ e uniformização de procedimento administrativo disciplinar".

${ }^{493}$ Vencidos os Ministros Marco Aurélio, relator, Ricardo Lewandowski, Celso de Mello e Cezar Peluso, Presidente, que referendavam a liminar por entenderem não ser permitido ao $\mathrm{CNJ}$, via resolução, criar, em processo disciplinar dos tribunais, novos procedimentos e definir quem participaria do julgamento. Assinalavam que o art. 14, caput, do preceito reproduziria o conteúdo do art. 27 da LOMAN, a implicar sobreposição passível de surtir efeitos normativos ou causar confusão caso esta fosse alterada. Vencido, também, o Ministro Luiz Fux, que a referendava parcialmente para fixar o prazo de 140 dias a fim de que as corregedorias locais apurassem os fatos que chegassem ao seu conhecimento e, superado este, caberia a intervenção do $\mathrm{CNJ}$, sem prejuízo da verificação da responsabilidade daquelas. Explicitava que o mencionado prazo seria formado a partir da soma de 60 dias previstos no art. 152 da Lei 8.112/90 com a sua prorrogação por idêntico período, acrescido de 20 dias para o administrador competente decidir o procedimento administrativo disciplinar, consoante o art. 167 do mesmo diploma. 
No que concerne ao $\S 1^{\circ}$ do art. $15^{494}$, o Colegiado referendou, também por votação majoritária, a liminar concedida. Aduziu-se tratar-se de nova hipótese cautelar de afastamento de magistrado do cargo. Realçou-se que eventual restrição às garantias da inamovibilidade e da vitaliciedade exigiria a edição de lei em sentido formal e material, sob pena de ofensa aos princípios da legalidade e do devido processo. Ademais, a própria LOMAN preveria essa medida quando da instauração de processo administrativo disciplinar ou do recebimento de ação penal acusatória (artigos 27, $\S 3^{\circ}$, e 29). O Ministro Celso de Mello lembrou que o tema diria respeito à reserva de jurisdição. ${ }^{495}$

Por fim, com relação à norma contida no parágrafo único do art. $21^{496}$, Tribunal, por maioria, deu interpretação conforme a Constituição para entender que deve haver votação específica de cada uma das penas disciplinares aplicáveis a magistrados até que se alcance a maioria absoluta dos votos, conforme preconizado no art. 93, VIII, da CF. Salientou-se que essa solução evitaria que juízo condenatório fosse convolado em absolvição ante a falta de consenso sobre qual a penalidade cabível. ${ }^{497}$

\section{V.5. A competência disciplinar do Conselho Nacional de Justiça à luz de suas próprias decisões}

Como se mencionou na Introdução deste trabalho, reservou-se para este espaço a apresentação de algumas decisões proferidas pelo próprio Conselho Nacional de Justiça em que se aborda mais diretamente o tema de sua competência disciplinar.

\footnotetext{
494 “O afastamento do Magistrado previsto no caput poderá ser cautelarmente decretado pelo Tribunal antes da instauração do processo administrativo disciplinar, quando necessário ou conveniente a regular apuração da infração disciplinar".

${ }^{495}$ Vencida a Ministra Rosa Weber, que denegava a pretensão ao fundamento de que, em cognição sumária, o controle da observância dos deveres funcionais dos magistrados estaria compreendido na competência do CNJ de editar normas de caráter primário para regrar suas atribuições.

496 "Na hipótese em que haja divergência quanto à pena, sem que se tenha formado maioria absoluta por uma delas, será aplicada a mais leve, ou, no caso de duas penas alternativas, aplicar-se-á a mais leve que tiver ob tido o maior número de votos"

${ }^{497}$ O Ministro Ayres Britto enfatizou que a norma seria operacional e consagraria uma atenuação punitiva. Vencidos os Ministros relator, Ricardo Lewandowski e Celso de Mello, que, por considerarem linear o critério referente à maioria absoluta, concluíam que o $\mathrm{CNJ}$ não poderia dispor, em sede meramente administrativa, sobre a questão e atuar de forma aleatória escolhendo a penalidade mais benéfica para o envolvido no processo. Registravam que a proposta olvidaria o voto médio. Por fim, o Supremo deliberou autorizar os Ministros a decidirem monocraticamente a matéria em consonância com o entendimento firmado nesta ação direta de inconstitucionalidade, contra o voto do Ministro Marco Aurélio.
} 
O Conselho Nacional de Justiça vem analisando um número considerável de processos. Concentrando-se em dados mais recentes, apenas na curta gestão do Ministro Ayres Britto na presidência do Conselho, no período entre abril e novembro de 2012, foram realizadas 13 sessões plenárias, autuados 5003 processos, e julgados 4032 processos. Publicaram-se 19 resoluções e recomendações e 15 parcerias com outros órgãos ou instituições foram firmadas. Importante ainda registrar que foram abertos 10 procedimentos administrativos disciplinares; apenas 5 magistrados foram de alguma forma punidos por decisão do Plenário, que afastou outros 6 magistrados preventivamente. Além disso, 5420 servidores do Judiciário realizaram atividades de capacitação. Foram visitadas pelo Projeto Justiça ao Jovem 59 unidades de internação de jovens em conflito com a lei, em 15 estados e no Distrito Federal. ${ }^{498}$

No que se refere especificamente ao exercício de sua competência disciplinar, deve-se informar que, no período entre 2006 a 2012, o Conselho aplicou algum tipo de sanção disciplinar 49 magistrados. Desse total, 24 foram punidos com a pena máxima no plano administrativo - a aposentadoria compulsória. Os casos mais rumorosos foram os do Ministro Paulo Medina, do Superior Tribunal de Justiça, e do desembargador José Eduardo Carreira Alvim, do Tribunal Regional Federal da $2^{\mathrm{a}}$ Região. Acusados de favorecerem máfias dos caça-níqueis, eles foram aposentados em 2010. Além disso, o CNJ colocou 6 magistrados em disponibilidade, afastou 15 provisoriamente, removeu 2 compulsoriamente e submeteu 1 à sanção de censura ${ }^{499}$. Alguns casos merecem destaque, como se verá a seguir.

A organização e publicidade da jurisprudência do Conselho são realizadas mediante o Sistema Infojuris, que pode ser acessado por meio do próprio site do órgão. Tal sistema consiste numa importante base de dados, da qual foram extraídas as informações sobre os casos analisados neste estudo.

Em pesquisa feita por meio do Sistema Infojuris, foi utilizado como critério de busca a expressão "Resolução 135". Dessa pesquisa, resultaram apenas vinte e seis (26) aparições da expressão em trechos de ementas, acórdãos e votos no âmbito do Conselho Nacional de Justiça.

Após avaliação do conteúdo de cada aparição, com o objetivo de filtragem e adequação aos propósitos deste trabalho, verificou-se que somente quinze (15) referiam-se

\footnotetext{
${ }^{498}$ Dados extraídos do próprio site do Conselho - www.cnj.jus.br.

${ }^{499}$ O Supremo Tribunal Federal e o futuro do CNJ. O Estado de São Paulo.
} 
a decisões efetivamente tomadas pelo Conselho, tanto relativas a consultas sobre matéria disciplinar de competência do Conselho, quanto referentes à efetiva aplicação de penalidades disciplinares em âmbito administrativo, com amparo no Regimento Interno do Conselho.

\section{No Processo de Revisão Disciplinar 0003862-86.2012.2.00.0000 500 ,} apontou-se que é passível de revisão a penalidade imputada a magistrado em desacordo com o conjunto probatório dos autos (art. 83, inc. I, do RICNJ). Consignou-se que a LOMAN é clara ao vincular a pena de advertência a atos omissivos, caracterizadores de conduta meramente negligente. A reiteração de condutas culposas e a verificação de procedimento incorreto do magistrado, ainda que desprovidos de má-fé, ensejam a aplicação da penalidade de censura, nos termos do art. 35, incs. I e II, c/c art. 42, inc. II, c/c art. 44, todos da LOMAN e do art. $4^{\circ}$ da Resolução n. 135 do Conselho Nacional de Justiça. Não há necessidade de correição do Conselho em vara judicial que já foi alvo de procedimentos correcionais recentes por parte do Tribunal de origem, sem que haja qualquer elemento novo que não foi avaliado por este. ${ }^{501}$

No Procedimento de Controle Administrativo 000288764.2012.2.00.0000 502 , entendeu-se que a Resolução n. 135/2011 dispõe, no seu art. 24, que o prazo de prescrição de falta funcional praticada pelo magistrado é de cinco anos, contado a partir da data em que o tribunal tomou conhecimento do fato, salvo quando configurar tipo penal, hipótese em que o prazo prescricional será o do Código Penal. Entendeu-se que a ciência do Presidente do Tribunal, a mais alta autoridade da Administração do Judiciário local, tomando conhecimento de suposta infração cometida por magistrado, tem o efeito de substituir a ciência do tribunal acerca do conhecimento do fato, podendo constituir termo inicial para a contagem do prazo prescricional.

No Pedido de Providências - Corregedoria 0004880-45.2012.2.00.0000 também se examinou o art. 24 da Resolução n. 135, de $2011^{504}$, e reafirmou-se o entendimento jurisprudencial no sentido de que, não estabelecida expressamente na

\footnotetext{
${ }^{500}$ Relator: Conselheiro Jefferson Kravchychyn. Data de Julgamento: 11/12/2012.

501 Julgou-se procedente a Revisão Disciplinar, consoante o art. 83, inc. I, c/c art. 88, ambos do Regimento Interno do Conselho Nacional de Justiça, para aplicar a penalidade de censura a magistrado, nos termos do art. 35, incs. I e II, c/c art. 42, inc. II, c/c art. 44, todos da LOMAN e do art. $4^{\circ}$ da Resolução n. 135 do Conselho Nacional de Justiça.

${ }^{502}$ Relator: Conselheiro Vasi Werner. Data de Julgamento: 11/12/2012.

${ }^{503}$ Relator: Conselheira Eliana Calmon. Data de Julgamento: 04/09/2012.

504 “O prazo de prescrição de falta funcional praticada pelo magistrado é de cinco anos, contado a partir da data em que o tribunal tomou conhecimento do fato, salvo quando configurar tipo penal, hipótese em que o prazo prescricional será o do Código Penal".
} 
LOMAN as regras atinentes à prescrição da pretensão punitiva do Estado em relação às infrações praticadas por magistrados, aplica-se subsidiariamente os arts. 142 e 143 da Lei n. $8.112 / 1990$.

Ainda sobre matéria prescricional no âmbito dos processos disciplinares, no Processo de Revisão Disciplinar 0003999-05.2011.2.00.0000 ${ }^{505}$ decidiu-se que inexiste a exigência de trâmite de processo penal para aplicação do prazo prescricional penal; trata-se de construção jurisprudencial que resta enfraquecida diante do novo regramento apresentado pela Resolução n. 135/2011. Os dois laudos periciais oficiais que embasaram a decisão proferida no Tribunal não podem ser simplesmente desconsiderados pelo Conselho diante do laudo produzido a pedido da requerente, ainda menos quando este foi feito a partir da cópia reprográfica do documento original.

No Processo Administrativo Disciplinar 0005107-69.2011.2.00.0000 instaurado pelo Conselho Nacional de Justiça em face de Desembargadora de Tribunal de Justiça estadual, o Plenário, por unanimidade, aprovou a procedimentos de investigação para apurar a prática, pela requerida, dos seguintes ilícitos: a) processamento irregular de precatórios; b) incompatibilidade entre os rendimentos e a movimentação financeira da magistrada; c) utilização do cargo em proveito pessoal; d) designação de magistrado em desacordo com a Instrução Normativa n.5/2008 e em ofensa ao princípio do juiz natural; e) cobrança de presentes e coação hierárquica; f) promoção pessoal por meio de propaganda irregular; g) irregularidades na gestão administrativa; e h) apropriação de arma recolhida. Com essas considerações, provada a parcial procedência das imputações, há que se reconhecer sua gravidade para, com fundamento nos artigos 35, I, II, III e VIII, e 56, II, da Lei Complementar n.35/79 (LOMAN), aplicar Desembargadora investigada a pena de aposentadoria compulsória, com proventos proporcionais ao tempo de serviço, nos termos dos artigos 28 e 42, V, da LOMAM e no art. $7^{\circ}$, II, da Resolução n.135, de 13 de julho de 2011, do Conselho Nacional de Justiça.

No Procedimento de Controle Administrativo /ML - Medida Liminar 0006006-33.2012.2.00.0000 507 , observou-se que a decisão de afastamento de magistrado deve ser tomada com maioria absoluta dos membros do tribunal, como impõe a Constituição Federal no art. 93, X, e a Resolução n. 135, de 2011. Neste sentido já decidiu

\footnotetext{
${ }^{505}$ Relator: Conselheiro Jorge Hélio. Data de Julgamento: 21/05/2012.

${ }^{506}$ Relator: Conselheiro Neves Amorim. Data de Julgamento 27/11/2012.

${ }^{507}$ Relator: Conselheiro Emmanoel Campelo.
} 
o Conselho em outras oportunidades, em especial visando a evitar máculas e desprestígio ao magistrado, cujo afastamento coloca em perigosa evidência perante a sociedade, em especial perante a comunidade jurídica.

No Processo de Revisão Disciplinar 0003707-83.2012.2.00.0000 ${ }^{508}$, tratouse de decisão do Tribunal de Justiça do Estado do Ceará que aplicou a magistrado a pena de censura por ter autorizado a transferência de detentos de estabelecimento penitenciário da comarca da qual era titular em desacordo com as normas legais. $\mathrm{O}$ fato que deu origem ao procedimento tornou-se conhecido em 25.07.2005. A sindicância foi instaurada em 04.08.2005 e o Processo Administrativo Disciplinar foi instaurado em 15.10.09. O julgamento do processo administrativo disciplinar ocorreu em 20.04.2012. A prescrição pela pena aplicada, que deve ser verificada entre a data de instauração do Processo Administrativo Disciplinar e a data da decisão tomada pelo Pleno ou Órgão Especial, não podendo retroceder à data anterior à instauração do processo administrativo disciplinar (tem por marco inicial o $141^{\circ}$ dia após a instauração do processo administrativo disciplinar, nos termos do art. 24, $\S 2^{\circ}$, da Resolução n. 135/2011), ou seja, o dia 05.03.2010. A pena que foi aplicada ao requerente é a de censura, cujo prazo prescricional é de dois anos, conforme precedente do Superior Tribunal de Justiça reiteradamente acolhido pelo Conselho. Noutras palavras, entre o início da contagem do prazo prescricional (05.03.2010) e a data do julgamento do processo administrativo disciplinar (20.04.2012), transcorreram-se mais de dois anos. Reconheceu-se, portanto, a prescrição pela pena aplicada, conforme previsão contida no art. 24, § 2º da Resolução n. 135/2011.

A Consulta 0003484-33.2012.2.00.0000 $0^{509}$ foi formulada pela Corregedoria Geral da Justiça do Estado do Rio Grande do Norte a fim de que o Conselho se manifestasse acerca da possibilidade de distribuição específica para os Processos Administrativos Disciplinares. Embora não haja nenhuma remissão, na Resolução n. 135/2011, ao modo de se realizar a distribuição, ela deve observar a regra geral para a distribuição do direito processual. O instituto da distribuição é orientado pelos critérios da alternatividade, publicidade e igualdade. Ora, há duas maneiras de se obter igualdade na distribuição: a distribuição pode ser feita de maneira única para todos os casos da competência de determinado órgão, ou é possível fazê-la por classes de modo que, para cada processo administrativo disciplinar seja sorteado um desembargador que, em seguida,

\footnotetext{
${ }^{508}$ Relator: Conselheiro Neves Amorim. Data de Julgamento: 04/09/2012.

${ }^{509}$ Relator: Conselheiro Neves Amorim. Data de Julgamento: 03/07/2012.
} 
seja excluído da distribuição posterior para processos da mesma classe até que todos os demais desembargadores tenham recebido um processo. O silêncio da Resolução não deve ser interpretado como uma omissão, mas, sim, como uma faculdade reconhecida aos demais Tribunais para que disciplinem a distribuição como lhes for mais oportuno, desde que obedecidos: o sorteio, a igualdade e a publicidade. Há que se conhecer e responder negativamente à consulta formulada: é desnecessária a distribuição una de processos administrativos e judiciais, desde que, seja qual for a opção para manter rigorosa igualdade na distribuição, conste de maneira prévia e pública nos regimentos internos do órgão judicial.

Na Reclamação Disciplinar 0001755-69.2012.2.00.0000 ${ }^{510}$, considerou-se necessária a instauração de Processo Administrativo Disciplinar contra Desembargadores, em razão dos fortes elementos indiciários e probatórios de conduta delituosa, consubstanciada em desvios de recursos públicos provenientes das contas destinadas ao pagamento de precatórios e requisições de pequeno valor. Consignou-se que a prática consiste em procedimento incompatível com os deveres previstos no art. 35, incisos I, VII e VIII, da Lei Complementar n. 35/1979, bem como aos princípios da imparcialidade, do conhecimento e capacitação, da transparência, da prudência, da diligência, da integridade profissional e pessoal, da dignidade, da honra e do decoro, expressamente previstos no art. $1^{\mathrm{o}}$ do Código de Ética da Magistratura. A gravidade dos atos imputados aos magistrados, que evidenciam a incompatibilidade com o exercício da função, colocando em risco a atividade judicante, a credibilidade de suas decisões e do próprio Poder Judiciário, bem como o curso normal das investigações, exige o afastamento das suas funções, nos termos do artigo 27, $\S 3^{\circ}$, da LOMAN e art. 15, $\S 1^{\circ}$ da Resolução n.135, de 2011, do Conselho Nacional de Justiça.

No Processo Administrativo Disciplinar 0006374-47.2009.2.00.0000 ${ }^{511}$, após a invocação da decisão proferida na ADI n. 4638, julgou-se improcedente o pedido de suspensão do trâmite do presente processo administrativo disciplinar e de anulação dos efeitos decorrentes de sua instauração, sob a alegação de inconstitucionalidade formal da Resolução n. 35/2011. Houve demonstração probatória suficiente da prática das condutas que caracterizam infração disciplinar. Procedência das imputações, ante a prática das condutas que violaram os deveres da magistratura estampados no artigo art. 35, incisos I e

\footnotetext{
${ }^{510}$ Relator: Corregedora Eliana Calmon. Data de Julgamento: 21/05/2012.

${ }^{511}$ Relator: Conselheiro Tourinho Neto. Data de Julgamento: 21/05/2012.
} 
VIII, da LC n.35, de 14 de março de 1979 - LOMAN, com aplicação da pena de aposentadoria compulsória, com vencimentos proporcionais ao tempo de serviço, de acordo com os artigos 28 e 42, V, do mesmo Diploma, e artigo $5^{\circ}$ da Resolução n. 30/2007 do Conselho Nacional de Justiça (atual art. $7^{\circ}$ Resolução/CNJ n. 135/2011).

No Recurso Administrativo em Procedimento de Controle Administrativo 0005712-15.2011.2.00.0000 512 , a anotação das penalidades aplicadas a magistrado, assim como das promoções, remoções, licenças, dentre outros, é mero ato de registro funcional, previsto no Regimento Interno do Tribunal, que, inclusive, determina sua preservação para assegurar a independência e a dignidade do cargo. A Resolução/CNJ n. 135 determina a anotação da penalidade nos assentamentos funcionais do magistrado, sem nenhuma ressalva de exclusão após determinado decurso de tempo. A anotação da falta funcional não foi utilizada, por si, para impedir a remoção do juiz, mas, sim, o fato de ele já ter sofrido diversas penalidades (advertência, censura e remoção compulsória) e estar afastado, nos autos de processo administrativo disciplinar a que responde; sendo que ainda há outros dois processos em curso contra magistrado. Se a manutenção do registro da penalidade está amparada na norma regimental, e a penalidade não está sendo utilizada em si para indeferir pedido de remoção, não cabe nenhum controle do ato pelo CNJ. Certidão juntada aos autos não comprova que o Tribunal valeu da referida pena de advertência para negar a remoção, pois não poderia expressar algo diferente do pronunciamento do Corregedor-Geral transcrito nos autos. Recurso administrativo não provido.

\section{No Processo de Revisão Disciplinar 0007176-45.2009.2.00.0000 ${ }^{513}$,} as provas colhidas sem a presença da Requerente na fase de inquérito, foram reproduzidas no processo em referência, sob o crivo do contraditório e da ampla defesa e mantidas inalteradas quanto a seu conteúdo, o que demonstra não ter sido a decisão baseada em provas falsas. Considerou-se que conduta da magistrada foi gravíssima, mas a pena aplicada violou o princípio da proporcionalidade. Com efeito, o juízo de culpabilidade, análogo ao feito na esfera penal, deve levar em conta a reprovabilidade da conduta. A alegada "soberba" que, a juízo do Conselheiro Relator, evidenciava personalidade reprovável da requerente somente deve integrar o juízo sobre sua conduta para se determinar a extensão da pena, não a sua natureza. A contrario sensu, este Conselho estaria a punir a pessoa e não sua ação. Por isso, ante a evidente incorreção de sua conduta,

${ }^{512}$ Relator: Conselheiro Tourinho Neto. Data de Julgamento: 28/02/2012.

513 Relator: Conselheiro Marcelo Nobre; Relator para Acórdão Neves Amorim. Data de Julgamento: 27/09/2011. 
mereceria a requerente, nos termos do art. $4^{\circ}$ da Resolução n. 135, a imposição da pena de censura. O que se afigura mais grave, contudo, não foi essa conduta, mas a sua recusa em pronunciar-se suspeita. Em conta desse fato e analisando objetivamente apenas sua conduta, entendeu-se que lhe deveria ser aplicada a pena de remoção compulsória. É que, com fulcro no art. $6^{\circ}$ da Resolução n. 135 deste Conselho, há que se reconhecer incidir, na a possibilidade de dar adequada punição à autora de modo menos gravoso. Os Conselheiros, por maioria, deram parcial provimento a esta Revisão para aplicar a pena de remoção compulsória à requerente. Determinaram, outrossim, remessa de cópia desta decisão ao Tribunal de origem para que, observando a destinação para outra comarca de entrância idêntica, porém não contígua ou pertencente ao mesmo polo, promovesse a remoção compulsória da requerente e, até que o Presidente do Tribunal de Justiça promova a remoção, a requerente deverá manter-se em disponibilidade.

No Recurso Administrativo de Pedido de Providências 000401204.2011.2.00.0000 $0^{514}$, entendeu-se que o poder que o titular da Vara ou Gabinete possui de indicar ao Presidente da Corte aqueles que, com ele, irão servir ao jurisdicionado depende do pleno exercício da titularidade nas referidas unidades. A indicação dos ocupantes dos cargos em comissão, dispensáveis 'ad nutum', é atribuição que não pode ser exercida durante o afastamento preventivo do magistrado, que fica impedido de utilizar o seu local de trabalho e usufruir de veículo oficial e outras prerrogativas inerentes ao exercício da função, nos termos do art. $15, \S 2^{\circ}$ da Resolução n. 135, de 2011. Tal atribuição deve ser plenamente exercida pelo magistrado convocado pelo Tribunal.

\section{No Recurso Administrativo em Procedimento de Controle Administrativo} 0002825-58.2011.2.00.0000 515 , destacou-se que apenas em Revisão Disciplinar se poderia analisando o mérito do julgamento disciplinar do magistrado, não sendo possível em sede de recurso administrativo. ${ }^{516}$

\footnotetext{
${ }^{514}$ Relator: Conselheiro Jorge Hélio. Data de Julgamento: 13/09/2011.

515 Relator: Conselheiro Jefferson Kravchychyn; Relator p/ Acórdão Sílvio Rocha. Data de Julgamento: 30/08/2011.

516 A Resolução n. 135, de 2011, prevê em seu artigo 27, que "o magistrado que estiver respondendo a processo administrativo disciplinar só terá apreciado o pedido de aposentadoria voluntária após a conclusão do processo ou do cumprimento da penalidade". À época dos fatos e da concessão da medida liminar vigia a Resolução n.30 de 07/03/2007, que em seu artigo $1^{\circ}$, $\S 5^{\circ}$, assim dispunha: "o magistrado que estiver respondendo a processo administrativo disciplinar só será exonerado a pedido ou aposentado voluntariamente após a conclusão do processo ou do cumprimento da pena”. O ato ora questionado, qual seja a aposentadoria voluntária, com proventos integrais, ao Juiz Federal Casem Mazloum, titular da $1^{\text {a }}$ Vara Federal Criminal da $1^{\text {a }}$ Subseção Judiciária do Estado de São Paulo, descumpre frontalmente a disposição citada anteriormente ao tempo em que está pendente de análise recurso em Processo Administrativo Disciplinar em face do magistrado mencionado. Existem, no âmbito do Conselho da Justiça Federal, recursos sujeitos à análise e que
} 
No Pedido de Providências 0003970-52.2011.2.00.0000 ${ }^{517}$, anotou-se que a maioria absoluta dos integrantes do Pleno do Tribunal de Justiça decidiu que os fatos imputados à magistrada justificavam a aplicação de pena administrativa, divergindo apenas quanto à espécie incidente. Decisão contrária à evidência dos autos, no sentido do arquivamento do processo, sem a aplicação de qualquer sanção. Exegese do art. 93, X, da Constituição Federal, que inspirou o conteúdo do parágrafo único do art. 21 da Resolução 135 do CNJ, segundo o qual: na hipótese em que haja divergência quanto à pena, sem que se tenha formado maioria absoluta por uma delas, será aplicada a mais leve, ou, no caso de mais de duas penas alternativas, aplicar-se-á a mais leve que tiver obtido o maior número de votos. Decidiu-se, assim, pela aplicação de pena de censura à magistrada.

Outros casos, anteriores à vigência da Resolução n. 135/2011, também merecem destaque.

No voto do Conselheiro Joaquim Falcão proferido no Procedimento de Controle Administrativo n. 2007.100000149-42 $2^{518}$, utilizando-se conceituação doutrinária das características dos atos administrativos ${ }^{519}$, ponderou-se que as decisões do CNJ são decisões judiciais de caráter administrativo e plenamente dotadas de eficácia e cogência, bem como apresentam as características dos atos administrativos - presunção de legitimidade, presunção de legitimidade, imperatividade, autoexecutoriedade e tipicidade $^{520}$. Não se confundem, portanto, com decisões jurisdicionais das quais cabe recurso, reforma ou mesmo duplo grau de jurisdição. Não são reformáveis, nem apreciáveis por outros órgãos. Todas as hipóteses previstas são as esgotadas em seu Regimento Interno e na Constituição Federal. ${ }^{521}$ Note-se que não é competência recursal, mas competência, frise-se, originária, para julgar ações contra o próprio órgão, podendo,

podem, de forma hipotética, culminar na aplicação de sanções previstas na Lei Orgânica da Magistratura Nacional, ao magistrado a que se aposenta. Negado provimento ao recurso.

${ }^{517}$ Relatora: Corregedora Eliana Calmon. Data de Julgamento: 16/08/2011.

${ }^{518}$ Revista de Direito Administrativo n. 253.

${ }^{519}$ Di Pietro, 2004: São características dos atos administrativos: a) a presunção de legitimidade: "diz respeito à conformidade à lei”; b) a presunção de veracidade: “diz respeito aos fatos;[...] presumem-se verdadeiros os fatos alegados pela Administração"; c) a imperatividade: "os atos administrativos se impõem a terceiros, independentemente de sua vontade"; d) a autoexecutoriedade: "atributo pelo qual o ato administrativo pode ser posto em execução pela própria Administração Pública"; e) a tipicidade: "o ato administrativo deve corresponder a figuras previamente previstas em lei".

${ }^{520}$ Porque ao CNJ compete o controle da atuação administrativa e financeira do Poder Judiciário (CF, art. $\left.103-\mathrm{B}, \S 4^{\circ}\right)$, podendo expedir atos regulamentares $\left(\mathrm{CF}\right.$, art. $\left.103-\mathrm{B}, \S 4^{\circ}, \mathrm{I}\right)$.

${ }^{521}$ Nesse sentido, deve-se lembrar que o art. 102, I, r, da Constituição da República, estabelece que compete ao Supremo Tribunal Federal, precipuamente, a guarda da Constituição, cabendo-lhe processar e julgar, originariamente, as ações contra o Conselho Nacional de Justiça e contra o Conselho Nacional do Ministério Público. 
portanto, anular suas decisões. Dessa forma, somente o Supremo pode desconstituir decisão do Conselho.

\section{No Pedido de Avocação de Processo Administrativo Disciplinar $n$.} 2008.100000128-22 $2^{522}$, de relatoria do Conselheiro Rui Stocco, diante de uma demora de mais de quatro anos para a efetivação das investigações a serem realizadas pelo Tribunal Regional do Trabalho da $8^{\mathrm{a}}$ Região, em um quadro marcado por suspeitas de fraude e de inúmeras alegações de suspeições por parte dos Juízes daquele tribunal, o Plenário do CNJ deliberou pela avocação do processo disciplinar. O conjunto de imputações constante nos autos revelava a gravidade dos fatos cometidos pelo magistrado processado, comprovados em três oportunidades distintas: ao longo da sindicância levada a efeito no Tribunal de origem, nos depoimentos colhidos no processo administrativo disciplinar, enquanto teve curso na Corte de origem, e nos depoimentos colhidos pelo Conselheiro Rui Stocco, já no âmbito do CNJ. Considerou-se que a messe probatória colacionada nos autos, farta e conclusiva, revelava a inaptidão do magistrado investigado para o exercício do cargo, seja pelo seu comportamento profissional, no exercício da função pública, seja em razão de sua conduta na vida privada. Assim, diante da comprovação de (i) que a conduta do magistrado foi incompatível com a dignidade, a honra e o decoro necessários ao exercício da função; (ii) que houve violação reiterada dos deveres de imparcialidade e a ocorrência de tráfico de influência; (iii) de excessiva e reiterada morosidade na resolução das causas submetidas ao magistrado para decisão, mostrando-se manifestamente negligente no cumprimento de seus deveres - o que foi constatado em inúmeras correições; (iv) que investigado teve comportamento funcional incompatível com o bom desempenho das atividades jurisdicionais; e (v) a comprovação de favorecimento em determinados processos - a rápida e expedita elaboração de cálculos para uns em detrimento da morosidade para outros, o Plenário do Conselho Nacional de Justiça, por maioria absoluta de seus membros, julgou procedentes as imputações feitas e aplicou ${ }^{523}$ ao magistrado processado a pena de aposentadoria compulsória por interesse público, com subsídios proporcionais ao tempo de serviço.

\footnotetext{
${ }_{522}$ Revista de Direito Administrativo, n. 252.

523 Com fundamento no art. 103-B, $\$ 4^{\circ}$, inciso III da Constituição Federal, art. 28 da Lei Orgânica da Magistratura Nacional, e art. $5^{\circ}$ da Resolução n. 30, de 2007, do Conselho Nacional de Justiça.
} 
No Processo de Revisão Disciplinar n. 200810000031956, de relatoria do Conselheiro Marcelo Neves ${ }^{524}$, entendeu-se que deve ser arquivado pedido de revisão disciplinar, quando extrapolado o prazo de um ano previsto no art. $103-\mathrm{B}, \S 4^{\mathrm{o}}$, inc. $\mathrm{V}$ da Constituição Federal, como limite revisional dos procedimentos disciplinares instaurados no âmbito do Poder Judiciário, contado a partir da decisão impugnada. Ademais, não cabe ao Conselho Nacional de Justiça revisar determinação de arquivamento de representação criminal em decisão judicial do Tribunal de Justiça.

No Processo Administrativo Disciplinar n. 200910000053701 de relatoria do Conselheiro Marcelo Neves ${ }^{525}$, após rigorosa análise de dosimetria da pena, aplicou-se a pena de disponibilidade compulsória ao procedimento incorreto praticado pelo Requerido de maneira reiterada. Tratou-se de conduta consistente em excesso de linguagem manifestada em expressões de discriminação ao gênero feminino, de modo análogo ao de crime de racismo. O excesso de linguagem comporta níveis de gravidade. No presente caso, configurou-se alta reprovabilidade. Além das expressões utilizadas no exercício da atividade judicante, por meio de sentença, o Requerido conferiu extensa publicidade ao conteúdo da mesma, concedendo entrevistas e divulgando nota em diversos meios de comunicação, assim como, ainda mais grave, manteve por longa data livre acesso ao teor da sentença em seu "site" pessoal na rede mundial de computadores, insistindo na correção de sua conduta.

No Processo Administrativo Disciplinar n. 200910000032357 de relatoria do Conselheiro Marcelo Neves ${ }^{526}$, entendeu-se que são inexigíveis, na sindicância, tanto a presença do sindicado, quanto a observância do contraditório e da ampla defesa, razão pela qual não se verifica qualquer nulidade capaz de macular o processo administrativo disciplinar. O prazo de conclusão da sindicância é incapaz de gerar nulidade, em especial por decorrer do prestígio ao direito de defesa e não ter causado prejuízo algum ao magistrado requerido. Possuem os magistrados total independência no seu exercício jurisdicional, contudo, administrativamente, traz consigo deveres. Assim, exige-se o cumprimento de certos padrões de conduta, especialmente aqueles referentes aos Princípios da Administração Pública, entre os quais a Moralidade e a Impessoalidade, que

\footnotetext{
524 CNJ - REVDIS 200810000031956 - Rel. Cons. Marcelo da Costa Pinto Neves - $91^{\text {a }}$ Sessão - j. 29/09/2009 - DJU n. 190/2009 em 05/10/2009, p. 05.

${ }^{525}$ CNJ - PAD 200910000053701 - Rel. Cons. Marcelo da Costa Pinto Neves - 116 a Sessão - j. 09/11/2010 - DJe n. 206/2010, em 11/11/2010, p.18/19

${ }^{526}$ CNJ - PAD 200910000032357 - Rel. Cons. Marcelo da Costa Pinto Neves - 93 ${ }^{\text {a }}$ Sessão - j. 27/10/2009 DJU n. 209/2009, em 03/11/2009, p. 02.
} 
se fazem sujeitos ao exercício do poder disciplinar conferido Constitucionalmente ao Conselho Nacional de Justiça. (art. 103, § 4, $\mathrm{CF}$ ). A atuação do Requerido sugere, se não o propósito direcionado do Magistrado, ao menos sua desídia por conceder tutela antecipatória em processo que continha decisão liminar em Agravo de Instrumento em sentido absolutamente oposto.Por ter o Magistrado Requerido descumprido os deveres previstos nos incisos I e VIII do art. 35 da LOMAN e inciso I do art. 125 do Código de Processo Civil, aplicou-se a pena de colocação em disponibilidade com vencimentos proporcionais ao tempo de serviço, nos termos do art. 42, inciso IV, da Lei Orgânica da Magistratura Nacional.

No Procedimento de Controle Administrativo n. 200910000058322, de relatoria do Conselheiro Marcelo $\mathrm{Neves}^{527}$, decidiu-se, com base em precedentes do Conselho, que não cabe a intervenção do Conselho Nacional de Justiça determinando suspensão de atos, quando sequer houve acusação formal, com instauração do Procedimento Administrativo Disciplinar, e não se vislumbra a existência de vício insanável.

\section{V.6 A competência disciplinar do Conselho Nacional de Justiça à luz de decisões do Supremo Tribunal Federal}

De acordo com a norma constitucionalmente prevista no art. 102, I, "r", compete ao Supremo Tribunal Federal o julgamento das ações contra o Conselho Nacional de Justiça. Tem sido frequente o ajuizamento de processos na Suprema Corte, sobretudo por meio de Mandados de Segurança, em face de decisões proferidas pelo Conselho, sobretudo em matéria disciplinar. Cumpre destacar alguns julgamentos neste sentido.

No julgamento conjunto do $M S 28.816$ e do $M S 28.102^{528}$, de relatoria do Ministro Joaquim Barbosa, o Supremo Tribunal Federal cassou decisão do Conselho Nacional de Justiça que determinara aposentadoria compulsória de juíza ${ }^{529}$ que fora condenada pelo Conselho porque teria determinado a prisão de uma garota menor de idade

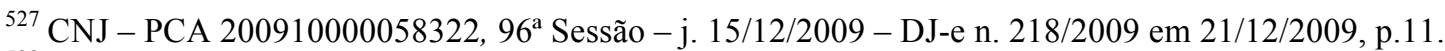

${ }^{528}$ Informativo Mensal de Jurisprudência do STF n.20, Junho de 2012 - "CNJ: PAD e punição de magistrado".

${ }_{529}$ A magistrada atuava na comarca de Abaetetuba, no estado do Pará. 
em uma cela masculina durante 24 dias, bem como teria falsificado documento para afastar sua responsabilidade no caso. ${ }^{530}$

Os Ministros do Supremo entenderam não haver evidências de que a juíza tinha ciência da circunstância em que foi cumprida a ordem de encarceramento ou que tenha agido intencionalmente ao determinar a prisão em uma cela masculina. Por esta razão, o Tribunal cassou a decisão do Conselho Nacional de Justiça, e determinou novo julgamento por este órgão, levando em conta, desta vez, apenas a acusação de falsificação. ${ }^{531}$

De acordo com o Relator, Ministro Joaquim Barbosa, por maior que seja a experiência e a capacidade técnica de um profissional, elas são insuficientes para afastar totalmente a possibilidade de erro. Assim, ao entender que havia na carceragem local a possibilidade de segregação de detentos por sexo, a juíza pode ter incorrido em erro de avaliação que não pode ser atribuído simplesmente a negligência ou imperícia.

Ademais, no caso em exame, a violação dos direitos da menor, argumentou o Ministro, decorreu de condutas excessivas de todos os agentes estatais envolvidos, a começar pela polícia. A circunstância de os policiais terem dever e possibilidade real de impedir os abusos ocorridos na carceragem é por sua vez insuficiente para afastar a responsabilidade das demais autoridades estatais envolvidas. Com a falha dos policiais, os papéis do Ministério Público, do conselho tutelar e do próprio juiz ganhariam relevância extraordinária.

O Ministro Relator também entendeu que o Conselho, ao condenar a magistrada, fez juízo de valor sobre ato jurisdicional. Com efeito, ao lavrar o ato de prisão, o juiz pode fazer considerações sobre as condições de encarceramento - o que não é um ato administrativo, mas judicial, que poderia ser revisto apenas por outra autoridade judiciária com competência jurisdicional.

\footnotetext{
${ }^{530}$ Assinalou-se que o CNJ decidira pela punição da impetrante com base em três argumentos: a) ao examinar o auto de prisão em flagrante, a magistrada sabia, ou deveria saber, que o lugar de custódia da menor a colocaria em situação de risco. Entretanto, não tomara nenhuma providência acauteladora; b) ao receber o ofício da autoridade policial sobre a questão, ela deveria ter tentado solucionar a situação lesiva imediatamente; e c) ao ficar ciente da ampla comoção social decorrente de sua desídia, a juíza teria fraudado documentação com o objetivo de comprovar a tomada imediata de providências. "Informativo Mensal de Jurisprudência do STF n.20, Junho de 2012 - "CNJ: PAD e punição de magistrado"

${ }^{531}$ Segundo os autos, a juíza teria alterado uma certidão expedida pelo diretor de Secretaria da $3^{\text {a }}$ Vara da Comarca de Abaetetuba, atestando a transmissão de fac-simile, em 8 de novembro de 2007, para a Corregedoria do Interior, autorizando a transferência da presa da delegacia para a capital do estado. O ofício só teria sido encaminhado no dia 20 de novembro de 2007 , com data retroativa ao dia 7 de novembro.
} 
Assim, concluiu o Ministro Joaquim Barbosa, ao Conselho Nacional de Justiça caberia avaliar, apenas, se a suposta falsificação de documento, caso restasse devidamente comprovada, é compatível, ou não, com o exercício da judicatura, bem como se a juíza objetivou furtar-se à responsabilidade pela fraude. ${ }^{532}$

Neste mesmo julgamento conjunto, denegou-se a ordem de segurança pleiteada no outro mandado, que tinha por fundamento o fato de que o Conselho instaurara Processo Administrativo Disciplinar contra a juíza impetrante, a despeito de a Corte local, à qual vinculada, haver determinado a não-instauração de procedimento. ${ }^{533}$

Analisando esta questão, considerou-se não haver cisão ontológica ou compartimentalização entre o procedimento administrativo disciplinar e a respectiva sindicância precedente. Afirmou-se que o resultado da sindicância integraria a motivação do ato de instauração do processo administrativo disciplinar ou sinalizaria a inércia do órgão correcional.

Portanto, a competência para controlar a validade da tramitação e do resultado do processo administrativo disciplinar também incluiria o controle de sua motivação, em outras palavras, da sindicância e de seu resultado. Ademais, se o CNJ somente pudesse examinar os processos disciplinares efetivamente instaurados, sua função seria reduzida à de órgão revisor de decisões desfavoráveis a magistrados, pois a decisão negativa de instauração de processo administrativo disciplinar pelos tribunais teria eficácia bloqueadora de qualquer iniciativa do Conselho.

É importante enfatizar que se reafirmou o entendimento proferido na ADI 4638-MC segundo o qual a instauração de processo administrativo disciplinar no âmbito das corregedorias locais não constitui pressuposto necessário, para o exercício, pelo Conselho Nacional de Justiça, da competência para rever, de ofício ou mediante

\footnotetext{
${ }^{532}$ Por maioria, acompanhando voto do ministro Marco Aurélio, o Tribunal determinou também que ao julgar novamente o caso, abordando apenas a acusação de falsificação de documento, o CNJ não determine novamente a pena de aposentadoria - determinando a suspensão, advertência ou outra punição prevista. Nesse ponto, ficaram vencidos o ministro Joaquim Barbosa e a ministra Cármen Lúcia, que não se pronunciaram sobre o conteúdo de uma eventual segunda condenação, e vencido também o ministro Dias Toffoli, que deferiu totalmente o pedido para cassar a decisão do CNJ em relação aos dois fundamentos - a negligência e a falsificação.

${ }^{533}$ A impetrante sustentava nulidade do ato impugnado, visto que: a) o CNJ somente teria competência para rever decisões proferidas ao término de $\mathrm{PAD}$; b) não haveria demonstração de que o tribunal de justiça teria agido em contrariedade às provas contidas em sindicância levada a termo pela corregedoria estadual; c) os fundamentos defensivos apresentados perante o CNJ não teriam sido apreciados; e d) a sessão em que proferido o ato fora presidida por integrante do STJ, em suposta afronta ao art. 103-B da Constituição da República.
} 
provocação, os processos disciplinares de juízes e membros de tribunais julgados há menos de um ano.

Em relação às disposições contidas no Regimento Interno do Conselho Nacional de Justiça, considerou-se inexistir violação à legalidade, consistente na ausência de autorização específica no Regimento Interno para determinar a instauração de processo disciplinar. Enfatizou-se que esse diploma deveria limitar-se a regulamentar a estrutura administrativa e o trâmite interno necessário ao exercício das atribuições outorgadas pela Constituição. Dessa forma, o Regimento Interno não pode aumentar a competência constitucional, nem reduzi-la.

Ademais, entendeu-se que o Conselho tem o poder-dever de exercer o controle externo da atividade administrativa dos tribunais, sem que se permita ao órgão dispor de seus encargos. Frisou-se decorrer dessa indisponibilidade e da regra da legalidade que o órgão não poderia ser impedido de rever pronunciamentos administrativos contrários à abertura de processo administrativo disciplinar.

Guardando relação com o tema da responsabilização judicial ${ }^{534}$, asseverouse inexistir imunidade absoluta aos titulares do ofício jurisdicional. Os juízes, como agentes públicos, responderiam por violações a que dessem causa, na medida da culpa caracterizadora das respectivas condutas. ${ }^{535}$

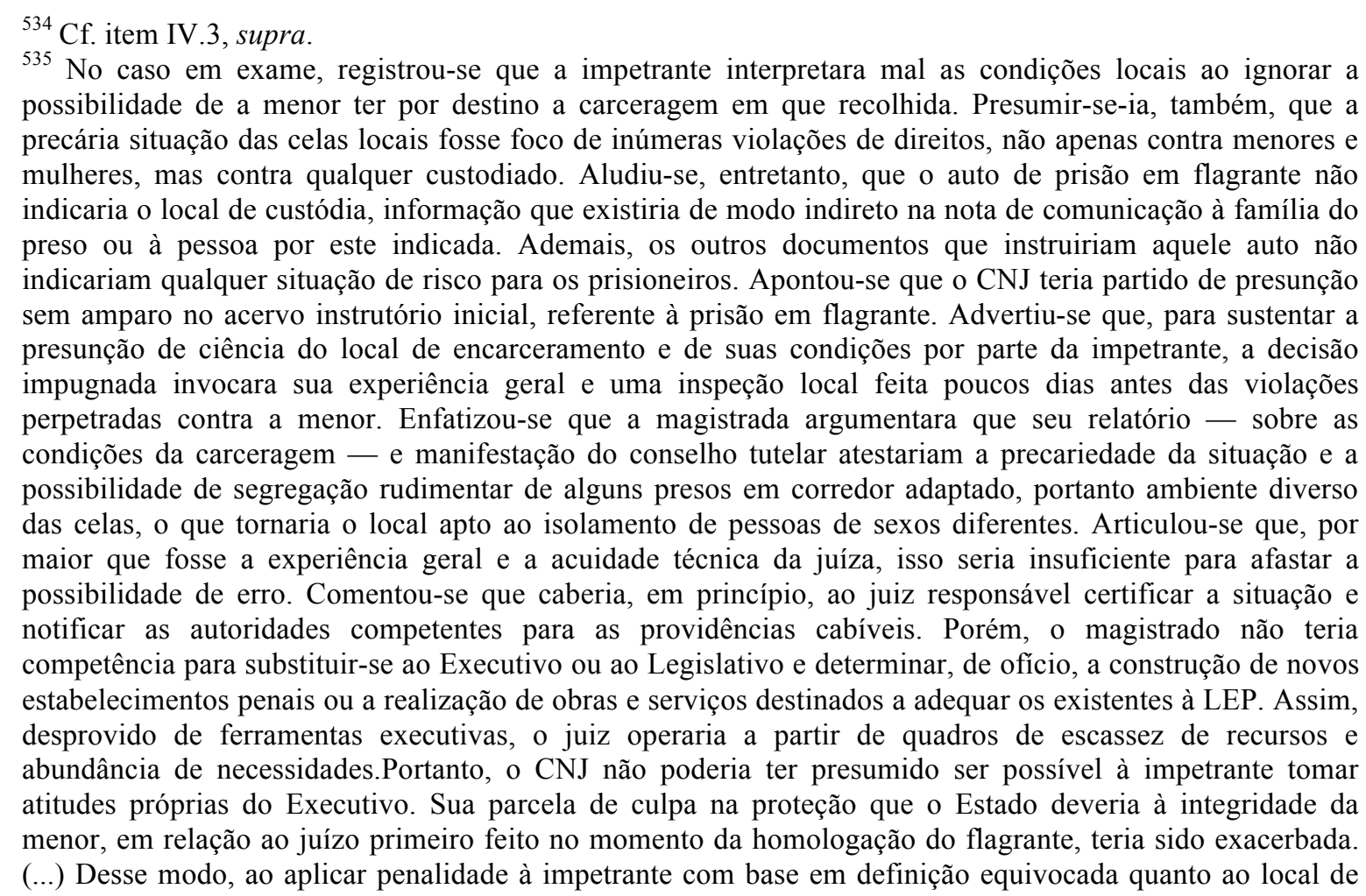


Com relação à aplicação das sanções disciplinares, estatuiu-se que, no tocante à imputação de falsidade ideológica, o Conselho não poderia aplicar a pena de aposentadoria compulsória, que seria desproporcional, mas deveria impor outra reprimenda, de menor gravidade. Assim, impenderia inaugurar novo processo administrativo disciplinar, eliminando-se a imputação alusiva à custódia em prisão masculina. Esclareceu-se que a aposentadoria deveria ser definitivamente afastada porque ela só seria compatível com o fato cujo fundamento fora excluído. ${ }^{536}$

No $M S 25.747^{537}$, em que foi relator o Ministro Gilmar Mendes, o Plenário do Supremo Tribunal Federal reafirmou seu entendimento no sentido da desnecessidade de lei complementar para dar efeitos ao art. 93, X, da Constituição da República, em face de sua auto-aplicabilidade.

Como consequência, denegou-se mandado de segurança impetrado contra decisão do Conselho Nacional de Justiça, que revogara atos administrativos, realizados no âmbito de Tribunal estadual, de remoção voluntária de magistrados, por terem sido editados em sessão secreta e desprovidos de motivação. O Conselho determinara que os atos fossem revogados e repetidos.

Asseverou-se que a referência à norma que estabelecera obrigatoriedade de sessão pública e votação nominal, aberta e fundamentada para a promoção por merecimento de magistrados, apresentar-se-ia como argumento de reforço à afirmação da necessidade dos mesmos parâmetros para as deliberações a respeito das remoções voluntárias dos membros do Poder Judiciário. ${ }^{538}$

encarceramento da menor, o CNJ teria invadido campo de competência reservado com exclusividade às autoridades judiciárias. "Informativo Mensal de Jurisprudência do STF n.20, Junho de 2012 - "CNJ: PAD e punição de magistrado".

${ }^{536}$ Vencidos os Ministros Joaquim Barbosa, relator, Cármen Lúcia e Dias Toffoli. O relator, acompanhado pela Ministra Cármen Lúcia, cassava apenas o primeiro fundamento da decisão do CNJ que determinara a aposentadoria compulsória, relativo à custódia em prisão masculina. Não alterava, entretanto, o segundo, alusivo à falsidade ideológica, por impossibilidade de fazê-lo em mandado de segurança. Assim, a questão deveria ser remetida novamente ao CNJ, para redimensionar a pena. O Ministro Dias Toffoli, por sua vez, concedia totalmente a ordem, para cassar a reprimenda imposta à magistrada. No tocante ao ofício subscrito com data incorreta, mencionava que o fato seria irrelevante, pois impenderia saber apenas a data em que produzidos seus efeitos. "Informativo Mensal de Jurisprudência do STF n.20, Junho de 2012 - "CNJ: PAD e punição de magistrado".

${ }^{537}$ Informativo Mensal de Jurisprudência do STF n. 19, Maio de 2012 - Remoção de magistrado: publicidade e fundamentação de ato administrativo.

${ }^{538}$ Precedentes citados: ADI 189/DF (DJU de 22.5.92); ADI $1303 \mathrm{MC} / \mathrm{SC}$ (DJU de $1^{\circ} .9 .2000$ ); RE 235487/RO (DJU de 21.6.2002). 
Com relatoria da Ministra Cármen Lúcia, no $M S 28.827^{539}$, cujo objeto era a análise do art. 130-A, $\S 2^{\circ}$, III - alcance da expressão "sem prejuízo" -, concluiu-se que eventuais abusos e arbitrariedades dos órgãos correcionais estaduais poderiam ser aventados nos Judiciários locais, garantida a inafastabilidade de jurisdição, a preservar o Supremo de se tornar espécie de tribunal administrativo de última instância para discussão de matérias de índole pessoal. ${ }^{540}$

No MS 28.003 ${ }^{541}$, inicialmente de relatoria da Ex-Ministra Ellen Gracie, posteriormente de relatoria do Ministro Luiz Fux, o Plenário do Supremo Tribunal Federal, por maioria, denegou mandado de segurança impetrado por juíza de direito contra decisão do Conselho Nacional de Justiça que, nos autos de reclamação disciplinar, determinara a instauração de processo administrativo em seu desfavor, bem como em relação a outros juízes, desembargadores e servidores do tribunal de justiça local. A impetrante requeria a declaração de nulidade da decisão impugnada, com o consequente arquivamento do processo $^{542}$.

Preliminarmente, reconheceu-se a competência do Supremo Tribunal Federal para o exame da matéria e a possibilidade de o Presidente do Conselho Nacional de Justiça delegar a sua atribuição de presidir as sessões plenárias e de se licenciar ${ }^{53}$ Acrescentou-se, inclusive, alteração regimental para permitir ao Vice-Presidente do Supremo substituir o Presidente do CNJ. Ressaltou-se, todavia, que, na época do julgamento da reclamação disciplinar, esta regra ainda não estaria em vigor. Anotou-se que a exigência constitucional de que o Presidente do Supremo, em sua condição institucional de Presidente do Conselho, fosse substituído em seus impedimentos e ausências eventuais pelo Vice-Presidente do Supremo teria surgido com a redação da EC 61/2009.

No mérito, aduziu-se competir ao Conselho o controle do cumprimento dos deveres funcionais dos magistrados brasileiros, cabendo-lhe receber e conhecer de

\footnotetext{
${ }^{539}$ Informativo Mensal de Jurisprudência do STF n. 21, Agosto de 2012 - "CNMP e competência revisional".

${ }^{540}$ Trata-se de análise relativa ao Conselho Nacional do Ministério Público, mas sua fundamentação é hábil para servir de parâmetro a casos semelhantes no âmbito do Conselho Nacional de Justica.

${ }^{541}$ Informativo Mensal de Jurisprudência do STF n. 17, Março de 2012 - CNJ: dispensa de sindicância e interceptação telefônica.

${ }^{542}$ Sustentava, em síntese, que: a) o julgamento teria sido presidido por conselheiro do CNJ; b) o processo administrativo estaria fundado em escutas telefônicas autorizadas por juízo incompetente, as quais seriam oriundas de inquérito cujo objeto seria distinto das supostas irregularidades a ela atribuídas; e c) o CNJ obstara o processamento de sindicância no âmbito da Corte estadual.

${ }^{543}$ RICNJ, artigos $3^{\circ}, 4^{\circ}$, III, IV, XXVI, 5 ${ }^{\circ}, 6^{\circ}$, IV, e 23, I. No ponto, em obiter dictum, o Ministro Luiz Fux, ao invocar o princípio da segurança jurídica, vislumbrou a possibilidade de modulação dos efeitos da decisão, com a finalidade de preservar-se a higidez dos atos realizados pelo $\mathrm{CNJ}$ em sessões pretéritas presididas por conselheiro não integrante do Supremo.
} 
reclamações contra membros do Poder Judiciário ${ }^{544}$. Consignou-se que, tendo em conta o princípio da hermenêutica constitucional dos "poderes implícitos", se a esse órgão administrativo fora concedida a faculdade de avocar processos disciplinares em curso, de igual modo, poderia obstar o processamento de sindicância em tramitação no tribunal de origem, mero procedimento preparatório. Ademais, realçou-se que, no caso, o CNJ concluíra pela existência de elementos suficientes para a instauração de processo administrativo disciplinar, com dispensa da sindicância. Discorreu-se, ademais, não poder o Judiciário, do qual o CNJ seria órgão, omitir-se no tocante à averiguação de eventuais fatos graves que dissessem respeito à conduta de seus magistrados, ainda que colhidos via interceptação de comunicações telefônicas judicialmente autorizada em inquérito instaurado com o fito de investigar outras pessoas e fatos diversos.

Por fim, ponderou-se - apesar da tese defendida por alguns Ministros desta Corte no sentido da competência subsidiária do CNJ relativamente a processos disciplinares instaurados para apurar condutas funcionais de magistrados em seus tribunais de origem - que esse órgão já teria apreciado o processo de outros magistrados, inclusive, de desembargadores também envolvidos.

No $M S$ 31.655-MC, em que foi relator o Ministro Joaquim Barbosa, decidiu-se que "a passagem reproduzida deixa entrever a suficiência de motivos para a deflagração do processo administrativo disciplinar contra o autor e o seu afastamento cautelar do exercício do cargo. A narração dos fatos não perde contundência se excluídos aqueles relacionados estritamente à Sindicância n. 121/TO, razão por que eventual equívoco em sua menção não torna inválido o ato impugnado". Por isso, ausente a plausibilidade jurídica do direito alegado, indeferiu-se a liminar. Ademais, também foi indeferido o requerimento para que a tramitação do presente mandado de segurança observe o sigilo, porque os fatos apurados relacionam-se à prática de ilícitos no exercício de cargo público, inexistindo aspecto que diga respeito à exclusiva intimidade do impetrante ${ }^{545}$.

No MS 26.249 - DF, de relatoria da Ministra Cármen Lúcia, tratou se uma avocação de processo disciplinar originariamente em trâmite perante o Tribunal de Justiça local. A discussão girou em torno da utilização de prova emprestada no processo disciplinar. Em 8.8.2006, no Procedimento de Controle Administrativo n. 208, o Conselho

\footnotetext{
${ }^{544}$ Constituição da República, art. 103-B, parágrafo $4^{\mathrm{o}}$, III e IV.

${ }^{545}$ Nos termos do art. 93, IX, da Constituição da República.
} 
Nacional de Justiça decidiu: a) "deferir, por maioria, a medida liminar requerida para determinar o afastamento preventivo do Desembargador Sebastião Teixeira Chaves das funções de Presidente do Tribunal de Justiça do Estado de Rondônia, mantendo-o, porém, no cargo de desembargador"; b) "determinar, por unanimidade, a instauração de procedimento administrativo disciplinar para apuração dos fatos narrados na peça inicial do procedimento de controle administrativo, (...) e a avocação do processo disciplinar instaurado no âmbito do Tribunal de Justiça do Estado de Rondônia”. Foram impugnados os seguintes dispositivos: CR, art. 103-B, par. 4º II e III; arts. 19, 85 e 97 do Regimento Interno do CNJ. Referiu-se ao julgamento da Medida Cautelar na Ação Direta de Inconstitucionalidade n. 4.638/DF, em que se analisou a constitucionalidade de vários dispositivos da Resolução n. 135/2011 do Conselho Nacional de Justiça e concluiu pela competência concorrente do Conselho para instaurar, de ofício, processos disciplinares contra magistrados e avocar aqueles em tramitação nos tribunais. Se o Conselho Nacional de Justiça pode, de ofício, instaurar processos disciplinares, os conselheiros que requereram essa instauração não podem ser considerados suspeitos para julgar referido processo, sob pena de se inviabilizar o julgamento de todos os processos instaurados naquele Conselho. O Supremo Tribunal Federal assentou que "elementos informativos de uma investigação criminal, ou as provas colhidas no bojo de instrução penal, podem ser compartilhados para fins de instruir outro processo criminal ou procedimento administrativo disciplinar".

Na Questão de Ordem no Inquérito n. 2.424/RJ, Relator o Ministro Cezar Peluso, decidiu-se que "dados obtidos em interceptação de comunicações telefônicas e em escutas ambientais, judicialmente autorizadas para produção de prova em investigação criminal ou em instrução processual penal, podem ser usados em procedimento administrativo disciplinar, contra a mesma ou as mesmas pessoas em relação às quais foram colhidos". 546 .

No MS 24.803/DF, de relatoria do Ministro Joaquim Barbosa, o Plenário do Supremo Tribunal assentou em MS impetrado por magistrada contra ato do Conselho Nacional de Justiça, que, na reclamação disciplinar, determinou a instauração de processo administrativo contra ela. Naquela ocasião, assentou-se a legalidade da instauração de processo disciplinar no Conselho Nacional de Justiça e do uso de provas obtidas em

\footnotetext{
${ }^{546}$ Nesse mesmo sentido foi o que restou decidido na Petição 3.683-QO/MG, Relator Ministro Cezar Peluso, Plenário, DJ 20.2.2009.
} 
processo criminal. Consignou-se que, tendo em conta o princípio da hermenêutica constitucional dos "poderes implícitos", se a esse órgão administrativo fora concedida a faculdade de avocar processos disciplinares em curso, de igual modo, poderia obstar o processamento de sindicância em tramitação no tribunal de origem, mero procedimento preparatório. Discorreu-se, ademais, não poder o Judiciário, do qual o CNJ seria órgão, omitir-se no tocante à averiguação de eventuais fatos graves que dissessem respeito à conduta de seus magistrados, ainda que colhidos via interceptação de comunicações telefônicas judicialmente autorizada em inquérito instaurado com o fito de investigar outras pessoas e fatos diversos".

No MS 28.799 $9^{547}-D F$, de relatoria do Ministro Celso de Mello, entendeuse que cabe aos Tribunais, em geral, o exercício prioritário do poder disciplinar quanto aos seus membros e aos juízes a eles vinculados. Trata-se da principal decisão do Supremo Tribunal Federal a tratar do tema da competência disciplinar do Conselho Nacional de Justiça, antes do julgamento da MC-ADI 4638.

Invocando o princípio da subsidiariedade e enfatizando que sua decisão está passível de revisão em posterior exame, o Ministro Celso de Mello concedeu liminarmente a ordem de segurança aos juízes G.R.C., A.H.S.N. e J.C.S.C.D e suspendeu os efeitos das aposentadorias compulsórias a bem do serviço público - punição máxima imposta à Magistratura - que foram aplicadas pelo Conselho Nacional de Justiça aos magistrados.

A punição decorreu de processo administrativo disciplinar em que o CNJ concluiu ter sido criado um esquema de desvio de verbas públicas para socorrer a Loja Maçônica de Mato Grosso, presidida pelo desembargador presidente do Tribunal de Justiça do estado. Magistrados escolhidos pelo presidente do TJ receberam dinheiro, a título de atrasados, e fizeram empréstimos à Maçonaria.

Embora reconheça a possibilidade constitucional de o CNJ instaurar, em sede originária, procedimentos disciplinares contra magistrados locais, além da prerrogativa, também constitucional, de avocar procedimentos de natureza administrativodisciplinar, o Ministro Celso de Mello enfatizou que a atuação do Conselho deve observar o princípio da subsidiariedade, ou seja, o CNJ deve ter um papel subsidiário e complementar em relação aos tribunais, atuando somente quando constatada a ineficácia dos mecanismos ordinários de administração e repressão do Poder Judiciário local.

${ }^{547}$ Julgamento conjunto do MS 28799, MS 28801 e MS 28802. 
De acordo com o Ministro, apenas depois de esgotada a possibilidade de o próprio tribunal exercer sua competência disciplinar e correcional sem sucesso é que o CNJ estaria legitimado a atuar. Somente desta maneira, segundo o Ministro Celso de Mello, será possível harmonizar o convívio entre o autogoverno da magistratura e o poder de controle e fiscalização do CNJ. "O desempenho da atividade fiscalizadora (e eventualmente punitiva) do CNJ deveria ocorrer somente nos casos em que os Tribunais havendo tido a possibilidade de exercerem, eles próprios, a competência disciplinar e correcional de que se acham ordinariamente investidos - deixassem de fazê-lo (inércia) ou pretextassem fazê-lo (simulação) ou demonstrassem incapacidade de fazê-lo (falta de independência) ou, ainda, dentre outros comportamentos evasivos, protelassem, sem justa causa, o seu exercício (procrastinação indevida)".

Dessa maneira, a incidência do postulado da subsidiariedade, como requisito legitimador da prática concreta, pelo $\mathrm{CNJ}$, de uma competência complementar em matéria correcional, disciplinar e/ou administrativa, não só harmonizaria o exercício dessa jurisdição censória com o princípio da autonomia institucional dos tribunais, como conferiria, também, maior coeficiente de legitimidade jurídica à atuação desse órgão estatal, afirmou o Ministro em sua decisão.

O Conselho Nacional de Justiça ${ }^{548}$, sob pena de atuação ultra vires, não pode interferir em atos de conteúdo jurisdicional, emanados de quaisquer magistrados ou de Tribunais da República. Com base nesse entendimento, o Plenário desproveu agravos regimentais em que se pretendia a desconstituição de decisões liminares, proferidas pelo Ministro Celso de Mello, em mandados de segurança dos quais relator. As decisões impugnadas suspenderam a eficácia de deliberações administrativas emanadas do Corregedor Nacional de Justiça, cujo dispositivo declarara ineficazes julgamentos de tribunal de justiça concessivos de mandados de segurança impetrados perante a referida Corte. Reputou-se que, embora o CNJ esteja incluído na estrutura constitucional do Poder Judiciário, sua natureza seria meramente administrativa e sua competência teria sido definida, de modo rígido, pela Emenda Constitucional n. 45/2004/2004. Aduziu-se que as deliberações administrativas, objetos dos casos em apreço, seriam impregnadas de conteúdo jurisdicional e que o Supremo, na ADI 3367, já assentara posicionamento no sentido de não caber àquele órgão nenhuma competência cujo exercício fosse capaz de

\footnotetext{
${ }^{548}$ Informativo Mensal de Jurisprudência do STF n. 03, Outubro de 2010 - "Decisão Judicial e Suspensão de Efeitos pelo CNJ".
} 
interferir no desempenho da função típica do Poder Judiciário. Competir-lhe-ia, porém, dentre outras atribuições, fiscalizar o exercício dos deveres funcionais por parte do magistrado, e não a atividade jurisdicional dele. "Os estudos acadêmicos e a predominância das decisões tomadas no âmbito do $\mathrm{CNJ}$ restringem o controle dos atos dos juízes àqueles de natureza administrativa e disciplinar. Não podem invadir, portanto, o âmbito das atividades-fim. É a orientação acolhida pelo Supremo Tribunal Federal”. ${ }^{549}$

\section{V.7. Breves notas sobre a relação entre o Conselho Nacional de Justiça e o Supremo}

\section{Tribunal Federal}

O Supremo Tribunal Federal exerce uma influência determinante sobre o Conselho Nacional de Justiça. ${ }^{550}$

Uma primeira razão para essa influência é em função do arranjo institucional constitucionalmente estabelecido: o Presidente do Supremo também preside o Conselho, desempenhando papel fundamental na condução política do órgão - "o qual pode adquirir uma feição mais ou menos corporativa, de acordo com o perfil e o impulso do Ministro que o preside" ${ }^{, 51}$; além disso, o Supremo é responsável pela indicação de outros dois Conselheiros - os membros de primeira e de segunda instância da Magistratura estadual.

Uma segunda razão reside no fato de o Supremo decidir, em única e última instância, sobre a conformidade das decisões do Conselho com a Constituição. Não se pode olvidar que, no julgamento da Ação Direta de Inconstitucionalidade n. 3367, salientou-se, considerando a natureza dita exclusivamente administrativa do Conselho Nacional de Justiça, que sua competência para as atribuições de controle da atividade administrativa, financeira e disciplinar da magistratura é destinada a todos os Tribunais e juízes, exceto o Supremo Tribunal Federal, destacando a preeminência deste, como órgão

\footnotetext{
${ }^{549}$ Outros precedentes citados: MS 27148/DF (DJe de 25.5.2010) e MS 28537 MC/DF (DJe de 21.5.2010).

${ }^{550}$ Para uma análise mais detalhada desta relação, recomenda-se a leitura do texto de Joaquim Falcão, Diego Arguelhes e Pablo Cedeira (2012), intitulado "O diálogo entre o CNJ e o STF". Para um questionamento acerca do grau e a legitimidade da interferência do STF sobre a atuação do CNJ, ver Deocleciano (2010), em especial pp. 101-11. Este mesmo autor também analisa a questão da legitimidade do CNJ como autor e réu (2010, pp. 112 e ss.).

${ }^{551}$ Badin, 2009, p. 35.
} 
máximo do Poder Judiciário, sobre o Conselho, cujos atos e decisões estão sujeitas ao seu controle jurisdicional, sustentando, ainda, a inteligência do art. 102, caput, inciso I, letra "r", e $\S 4^{\circ}$, da Constituição Federal ${ }^{552}$.

É importante que se tenha em consideração que a Emenda da Reforma do Judiciário conformou o Conselho Nacional de Justiça em variados aspectos e, ao fazê-lo, definiu competências, o que ensejou a posterior tarefa de interpretar essas competências e seus limites. E, como cabe o Supremo a análise das decisões do Conselho Nacional de Justiça, é inevitável a grande influência da Suprema Corte em relação ao Conselho.

No estudo "O diálogo entre o CNJ e o STF”, pesquisou-se a jurisprudência do Supremo com relação aos atos do Conselho Nacional de Justiça e chegou-se a duas conclusões interessantes. A primeira conclusão apresenta-se no sentido de que a análise dos dados evidencia uma reiterada atuação das associações de magistrados, por meio de ações diretas de inconstitucionalidade - quase três ao ano -, para obter do Supremo uma interpretação limitadora dos poderes do CNJ. Os dados pesquisados revelam também que o Supremo é muito cauteloso ao apreciar estas ações. Com efeito, até a data da pesquisa "cinco anos após o início dessas estratégias processuais" - a Corte Suprema não decidiu em definitivo em favor das interpretações constitucionais limitadoras da competência do CNJ, apesar de terem sido reiteradamente pleiteadas por uma pluralidade de associações de magistrados. Ao contrário, na única vez em que se manifestou de forma conclusiva sobre a constitucionalidade de alguma resolução do CNJ - na ADC n. 12 - o Supremo rejeitou de forma inequívoca as pretensões limitadoras que haviam sido levantadas. ${ }^{553}$

Ainda no que se refere à relação entre o Conselho Nacional de Justiça e o Supremo Tribunal Federal, poder-se-ia indagar se o exercício da competência disciplinar do Conselho atinge também o Supremo e seus Ministros. A dúvida que emerge é saber se realmente não estaria também o Supremo sujeito ao controle administrativo, financeiro e disciplinar do Conselho, já que este foi concebido para atuar, em matéria administrativa, em relação a todos os tribunais do país.

Concorda-se com a clara advertência feita por Joaquim Falcão segundo a qual "se considerarmos o nosso Supremo Tribunal Federal não do ponto de vista do seu

${ }^{552}$ MS 26.209 - DF (Rel. Ministro Gilmar Mendes) - Contra decisão proferida no PCA n. 264/2006 Ressalte-se que a ordem constitucional assegura ao Conselho Nacional de Justiça espectro de poder suficiente para o exercício de suas competências (art. 103-B, CR/88), não podendo o STF substituí-lo no exame discricionário dos motivos determinantes de suas decisões, quando estas não ultrapassem os limites da legalidade e da razoabilidade.

${ }^{553}$ Falcão, 2012, sem paginação. 
poder jurisdicional, mas da perspectiva de seu poder administrativo, veremos que ele não detém competência para impor seu modelo de gestão aos demais tribunais do país. A hierarquia jurisdicional não se traduz em hierarquia gerencial". Não há, portanto, alcance interpretativo lógico que afirme o poder implícito, outorgado pela Constituição, pertinente a definir que o Supremo detém a última palavra em organização judiciária e que, por consequência não poderia se submeter às diretrizes de gestão administrativa do Conselho Nacional de Justiça. ${ }^{554}$

Nesse sentido, a limitação das atividades administrativas do Conselho é, para Pedro Deocleciano, mais uma "carta na manga" utilizada pelo Supremo, que “engenhosamente confunde atribuições de última instância recursal com última instância administrativa". 555

Ainda no que toca à relação em exame, é interessante registrar que Fernanda Flurh exerce uma espécie sui generis de jurisdição, pois apesar de sua atividade não apresentar alguns caracteres da jurisdição propriamente dita, tal como a definitividade, a atuação do Conselho apresenta traços marcantes como a substitutividade, a imparcialidade e a garantia ao duplo grau de jurisdição. ${ }^{556}$

Além disso, em uma proposta mais avançada, Flurh defende a possibilidade de exercício de controle de constitucionalidade de leis e atos normativos pelo Conselho Nacional de Justiça, seja em sede de fiscalização concentrada - caracterizada pela possibilidade de ampliação, por Emenda Constitucional, do rol de legitimados para a propositura das ações diretas de controle de constitucionalidade, de forma a incluir o Conselho Nacional de Justiça -, seja em sede de controle difuso - reconhecendo-se a possibilidade de o Conselho Nacional de Justiça exercer a físcalização da constitucionalidade de leis ou atos normativos nas suas decisões. ${ }^{557}$

\footnotetext{
${ }^{554}$ Falcão, 2006, p. 117.

${ }^{555}$ Deocleciano, 2010, pp. 106-107.

${ }^{556}$ Flurh, 2011, p. 244.

${ }^{557}$ Flurh, 2011, p. 241. O detalhamento de como seria esse exercício de controle de constitucionalidade de atos normativos submetidos à sua apreciação é apresentado nos seguintes termos (Flurh, 2011, pp. 246-247): "Conclui-se, portanto, que no julgamento de causas de sua competência, o Conselho Nacional de Justiça, surgindo questão prejudicial do mérito, ou seja, acerca da inconstitucionalidade de determinada lei ou ato normativo, na forma como aqui se defende, deverá o Conselho Nacional de Justiça submeter a questão ao julgamento do Plenário, aplicando-se, por analogia, o disposto no art. 97, da Constituição Federal, ou seja, defende-se que somente pelo voto da maioria absoluta de seus membros poderá o Conselho Nacional de Justiça declarar a inconstitucionalidade de leis ou atos normativos do Poder Público. Como não poderia ser diferente, da decisão Plenária do Conselho Nacional de Justiça, na qual se declara a inconstitucionalidade de lei ou ato normativo no âmbito das suas atribuições, na forma aqui defendida, caberá sempre Recurso para o Supremo Tribunal Federal, resguardando-se, deste modo, a atuação da Corte Máxima”.
} 
Caso se entenda possível um eventual controle de constitucionalidade exercido pelo Conselho Nacional de Justiça, tal como proposto por Flurh, - e um julgamento nesse sentido apenas poderia ser feito com definitividade pelo Supremo, o que é pouco provável que aconteça - novos elementos poderiam ser trazidos para a relação existente entre estes dois órgãos do Poder Judiciário. 


\section{CONSIDERAÇÕES FINAIS}

O estudo doutrinário específico da competência disciplinar do Conselho Nacional de Justiça apresenta-se como tarefa de considerável dificuldade ao pesquisador, sobretudo no âmbito de uma Dissertação de Mestrado.

Uma primeira razão para tal fato é por se tratar de tema que toca, a um só tempo, em diversos planos importantes do Direito Constitucional, como a repartição de poderes, o federalismo, a independência judicial, a interpretação constitucional, o que demanda, por si só, um razoável conhecimento de cada uma destas matérias.

Trata-se, além disso, de tema bastante recente, considerando-se, em especial, a breve existência do Conselho Nacional de Justiça - criado em 2004 e em funcionamento desde 2005 - e da Resolução n. 135 do Conselho Nacional de Justiça, de 2011, que dispõe sobre a uniformização do procedimento administrativo disciplinar aplicável aos magistrados. Esta circunstância contribui para a escassez de fontes de pesquisa, tanto em âmbito doutrinário - em que praticamente não existe trabalho monográfico sobre o tema -, como no plano jurisprudencial, de material que guarde relação direta e específica com o tema.

Diante dessa situação, objetivou-se estruturar, em torno da questão da natureza da competência disciplinar do Conselho Nacional de Justiça, uma análise das justificativas aptas a caracterizá-la como sendo de caráter concorrente, em relação às atribuições das corregedorias dos tribunais locais.

Nesse sentido, constatou-se que a contextualização da criação do Conselho Nacional de Justiça apresenta-se fundamental para a compreensão das competências que lhe foram atribuídas pelo legislador constituinte reformador de 2004.

Com efeito, pode-se dizer que a criação do Conselho foi a primeira e mais difícil barreira ultrapassada para alcançar os objetivos traçados pela Reforma do Judiciário de se conferir ao Poder Judiciário maior modernidade, celeridade, independência e democratização. 
Pode-se afirmar, também, que a criação do Conselho Nacional de Justiça contribuiu para efetivar os princípios constitucionais da eficiência - art. 37 - e da razoável duração do processo - art. $5^{\circ}$, LXXVIII.

Mais do que isso, a atuação do Conselho Nacional de Justiça, como órgão de coordenação, planejamento e controle administrativo, financeiro, funcional e disciplinar do Poder Judiciário, tem sido fundamental para o aperfeiçoamento do sistema de justiça brasileiro, na busca por um Poder Judiciário célere e eficiente, pressuposto necessário à realização do princípio da segurança jurídica e à busca pelo ideal de justiça.

Não se pode deixar de reconhecer o papel do Conselho na modernização da Justiça, assim como não se pode negar que a sua atuação vem proporcionando uma aproximação entre o Poder Judiciário e a sociedade, e contribuindo para a concretização de um ideal de proteção judicial efetiva.

A atuação do Conselho como principal órgão como propulsor de uma reforma do Sistema de Justiça Brasileiro se volta tanto para dentro do Poder Judiciário como para fora de si.

Do ponto de vista da opinião pública, vem ocorrendo um fenômeno que poderia ser caracterizado como de "dessacralização do Judiciário", aventando-se a possibilidade de punição de comportamentos desviantes, de questionamentos do que é visto como regalias e privilégios. Tal fenômeno, além de indicar um processo de mudanças no interior da Magistratura e na percepção sobre o Judiciário pela sociedade, indica também que "exigências centrais da democracia e da República - transparência e prestação de contas pelas instituições - se tornaram demandas de difícil reversão ${ }^{558}$.

No que se refere especificamente à sua competência de natureza disciplinar, de caráter administrativo (não-jurisdicional) e nacional, é importante não se esquecer de que a forma com que o poder disciplinar era exercido dentro do Poder Judiciário brasileiro era algo desconhecido.

E considerando que o mau funcionamento - ou o não-funcionamento dos mecanismos de controle - pode levar à impunidade e à insegurança jurídica, a existência do Conselho Nacional de Justiça é alentadora.

${ }^{558}$ Sadek, 2012, sem paginação. 
"Com independência e sem vinculações perversas", o Conselho Nacional de Justiça, tem sido capaz, "mediante os controles serenos e equilibrados que realiza", de combater os "focos das notórias falhas do Poder Judiciário brasileiro". Não se constitui um "um fator de supressão de independência dos juízes", mas, muito ao contrário, “quando bem conduzido, vem se comportando como eficiente esteio para essa independência, especialmente lá onde notoriamente os juízes reverenciam o arrogante e oportunista chefe político". 559

O Poder Judiciário possui grande responsabilidade na concretização dos direitos fundamentais, especialmente os de caráter judicial. Para tanto, deve atuar com o rigor que o regime democrático impõe. O Conselho Nacional de Justiça exerce relevante papel no planejamento e coordenação da política judiciária pátria, visando à celeridade processual, bem como à eficiência e confiabilidade na atuação dos órgãos jurisdicionais. Para tanto, e como órgão central do sistema judicial, vem procedendo à implantação de política judicial única, a abranger todos os órgãos jurisdicionais do país. "Parceiro, e não censor da Magistratura - que se mostra preparada para a definitiva modernização da Justiça no país - o Conselho vem recebendo o apoio da sociedade brasileira, ao perseguir e obter resultados que demonstram a melhora na qualidade do serviço público de prestação de justiça”. Por todas estas razões, "vem cumprindo - e bem cumprindo! - a missão constitucional a si destinada". 560

Mas não se pode esquecer que o esforço pela democratização e modernização do Poder Judiciário é um processo contínuo de construção, que envolve não apenas questões de reorganização interna do Judiciário, mas também questões que envolvem outras instituições dos outros Poderes, bem como questões que envolvem mudanças nos hábitos comportamentais dos indivíduos, de dentro e de fora do Judiciário.

Nesse sentido, cabe ponderar que as características próprias da sociedade brasileira, adotando-se a descrição sociológica de Raízes do Brasil, do historiador Sérgio Buarque de Holanda, tornam mais complexa e dificultosa a tarefa de construir as instituições de um país que se atrasou na história e agora busca o tempo perdido. ${ }^{561}$

Não se pode esquecer, igualmente, do alerta feita por Marcelo Neves, no sentido de que, muitas vezes "as propostas permanentes e repetidas de reformas

\footnotetext{
${ }^{559}$ Dinamarco, 2009, p. 420.

${ }^{560}$ Mendes, 2012, sem paginação.

${ }^{561}$ Schwartz, 2009, sem paginação.
} 
constitucionais abrangentes desempenham antes uma função simbólica". Não se pode atribuir a "responsabilidade pelos graves problemas sociais e políticos" apenas à Constituição, "como se eles pudessem ser solucionados mediante as respectivas emendas ou revisões constitucionais". É preciso ter sempre a consciência de que as "leis constitucionais não podem [sozinhas] resolver imediatamente os problemas da sociedade", e de que, muitas vezes "problemas jurídicos e políticos que frequentemente se encontram na ordem do dia estão associados à deficiente concretização normativo-jurídica do texto constitucional existente", ou seja, estão mais relacionados com a falta das "condições sociais para a realização de uma Constituição inerente à democracia e ao Estado de direito do que nos próprios dispositivos constitucionais" ${ }^{\text {} 562}$. 


\section{REFERÊNCIAS BIBLIOGRÁFICAS}

BADIN, Luiz Armando (2009). "O Conselho Nacional de Justiça: pedra angular da reforma constitucional do poder judiciário". Revista Brasileira de Estudos Constitucionais. Belo Horizonte, ano 3, n. 9, jan./mar. 2009, pp. 27-39.

BANDEIRA DE MELLO, Celso Antônio (2004). Curso de Direito Administrativo Brasileiro. 17. ed. São Paulo: Malheiros.

BERCOVICI, Gilberto (2005). “O controle externo do judiciário e a soberania popular”. In TAVARES, André Ramos; LENZA, Pedro; ALARCÓN, Pietro de Jesús L. (Coord.). Reforma do judiciário: analisada e comentada: Emenda Constitucional n. 45/2004. São Paulo: Método.

CALMON, Eliana (2012). “CNJ e Democratização do Poder Judiciário”. In: Revista Interesse Nacional, 16 ed., janeiro de 2012. Disponível online em: http://interessenacional.uol.com.br/2012/01/o-dialogo-entre-o-cnj-e-o-supremo/. Acesso em: 27.11.2012.

CAPPELLETTI, Mauro (1989). Juizes irresponsáveis? Trad. de Carlos Alberto Álvaro de Oliveira. Sergio Antonio Fabris: Porto Alegre.

CARVALHO FILHO, José dos Santos (2010). “Conselhos Nacionais da Justiça e do Ministério Público: complexidades e hesitações”. In: Revista Interesse Público. Belo Horizonte, ano 12, n. 63, set./out. 2010, pp. 15-38.

CHIMENTI, Ricardo Cunha (2005). “Órgão especial. O Conselho Nacional de Justiça e os predicamentos da Magistratura”. In: TAVARES, André Ramos; LENZA, Pedro; ALARCÓN, Pietro de Jesús L. (Coord.). Reforma do judiciário: analisada e comentada: Emenda Constitucional n. 45/2004. São Paulo: Método.

CIRNE LIMA, Ruy (2007). Princípios de Direito Administrativo. 7 ed. São Paulo: Malheiros.

COELHO, Marcus Vinícius Furtado (2012). "Função do CNJ é concorrente às corregedorias". Artigo publicado em 14 de janeiro de 2012 no site Consultor 
Jurídico. Disponível online em: http://www.conjur.com.br/2012-jan-14/cnjcomplementa-trabalho-corregedorias-tribunais. Acesso em 23/09/2012.

CONSELHO NACIONAL DE JUSTIÇA. Relatório Anual. 2010. Disponível em: http://www.cnj.jus.br/images/relatorios-anuais/cnj/relatorio_anual_cnj_2010.pdf. Acesso em: 26/06/2011.

CONSELHO NACIONAL DE JUSTIÇA. Relatório Anual. 2009. Disponível em: http://www.cnj.jus.br/images/relatorios-anuais/cnj/relatorio_anual_cnj_2009.pdf. Acesso em: 25/06/2011.

CRETELLA JUNIOR, José (1966-1974). Tratado de Direito Administrativo. v. 6. Processo Administrativo. Rio de Janeiro: Forense.

DALLARI, Dalmo de Abreu (2008). O poder dos juízes. 3. ed. São Paulo: Saraiva.

DEOCLECIANO, Pedro Rafael Malveira (2010). “O Conselho Nacional de Justiça e o controle democrático do Poder Judiciário: uma realidade possível?” Dissertação de mestrado apresentada à Universidade de Fortaleza. Fortaleza.

DINAMARCO, Candido Rangel (2009). Instituições de Direito Processual Civil. v. 1. 6. ed. São Paulo: Malheiros.

D’URSO, Luiz Flávio Borges (2011). “A competência do Conselho Nacional de Justiça”. Disponível online em: http://www.oabsp.org.br/palavra_presidente/2011/acompetencia-do-conselho-nacional-de-justica/. Acesso em 27/11/2012.

FALCÃO, Joaquim (2003). “A Reforma do judiciário: ação ou reação?” In: Revista Fórum, v. 2, n. 11, pp. 24-26, nov./dez. 2003.

(2005). “Estratégias para a Reforma do Judiciário”. In: RENAULT, Sérgio Rabello Tamm, BOTTINI, Pierpaolo, (Coord.) Reforma do Judiciário. São Paulo: Saraiva, pp. 13-28.

FALCÃO, Joaquim; ARGUELHES, Diego Werneck; e CERDEIRA, Pablo de Camargo (2012). "O Diálogo entre o CNJ e o Supremo". In: Revista Interesse Nacional, 16 ed., jan.2012. Disponível online em: http://interessenacional.uol.com.br/2012/01/odialogo-entre-o-cnj-e-o-supremo/. Acesso em: 27/11/2012. 
FLUHR, Fernanda Adriano (2011). “A Jurisdição Constitucional e o Conselho Nacional de Justiça: a possibilidade do exercício do controle concentrado de constitucionalidade pelo CNJ". Dissertação de Mestrado apresentada à Universidade Católica de Pernambuco. Recife.

FREITAS, Vladimir Passos de (2003). "História da Justiça no Brasil. Corregedoria, aspectos históricos. Controle disciplinar da Magistratura. Reforma constitucional e Conselho Nacional da Magistratura". In: . (Coord.). Corregedorias do Poder Judiciário. São Paulo: Revista dos Tribunais, pp. 17-49.

GANDRA DA SILVA MARTINS, Ives (2011). “A importância do CNJ”. Artigo publicado no jornal Folha de São Paulo em 02 de setembro de 2011.

GASPARINI, Diógenes (1995). Direito Administrativo. 4. ed. São Paulo: Saraiva.

GRANDA, Piedad González (1993). Independencia del juez y control de su actividad. Valencia: Tirant lo blanch.

GUERRA, Gustavo Rabay (2010). "Independência e integridade: o Conselho Nacional de Justiça e a nova condição da política judicial”. Tese de Doutorado apresentada à Universidade de Brasília. Brasília: UnB.

JOBIM, Nelson (2003). "A estrutura do sistema judiciário brasileiro sob o prisma histórico". In: WALD, Arnoldo; MARTINS, Ives Gandra S.; PRADO, Ney (Org.). $O$ direito brasileiro e os desafios da economia globalizada. Rio de Janeiro: América Jurídica.

(2012). "Debate revela viés corporativo". In: In: Revista Interesse Nacional, 16 ed., janeiro de 2012. Disponível online em: http://interessenacional.uol.com.br/2012/01/o-dialogo-entre-o-cnj-e-o-supremo/. Acesso em: 27/11/2012.

JORGE, Mario H (2005). "O Conselho Nacional de Justiça e o controle externo administrativo, financeiro e disciplinar do poder judiciário: violação do pacto federativo". In: WAMBIER, Luiz R. et al (Coord.). Reforma do judiciário: primeiras reflexões sobre a Emenda Constitucional n. 45/2004. São Paulo: RT. 
JUCÁ, Francisco Pedro (2005). "Reforma do Judiciário - algumas reflexões". In: TAVARES, André Ramos; LENZA, Pedro; ALARCÓN, Pietro de Jesús L. (Coord.). Reforma do judiciário: analisada e comentada: Emenda Constitucional n. 45/2004. São Paulo: Método.

MEDAUAR, Odete (2005). Direito Administrativo Moderno. 9 ed. São Paulo: Revista dos Tribunais.

MENDES, Gilmar Ferreira (2008). A evolução recente do Sistema Judiciário Brasileiro. Palestra do Presidente do STF proferida em 23 de outubro de 2008 na Biblioteca do Congresso dos Estados Unidos. Disponível em: http://www.stf.jus.br/repositorio/cms/portalStfInternacional/portalStfAgenda_pt_br/a nexo/Evolucao_Recente_do_Sistema_Judiciario_Brasileiro_vPort1.pdf. Acesso em: $22 / 09 / 2011$.

(2008). Gilmar Mendes defende limite em atuação do CNJ e foro especial. Disponível em: <http://www.conjur.com.br/2008-mar-19>. Acesso em: $19 / 05 / 2010$.

(2012). "O CNJ e a questão da Justiça". In: Revista Interesse Nacional, 16 ed., janeiro de 2012. Disponível online em: http://interessenacional.uol.com.br/2012/01/o-cnj-e-a-questao-da-justica. Acesso em: $27 / 11 / 2012$.

MENDES, Gilmar Ferreira. BRANCO. Paulo Gonet (2012). Curso de Direito Constitucional. São Paulo: Saraiva.

MONTESQUIEU, Charles Louis de Secondat, baron de la Brède et de (1995). O Espírito das Leis. (Trad. Fernando Henrique Cardoso e Leôncio Martins Rodrigues). Brasília: UnB, p. 186.

MORAES, Alexandre de (2006). Constituição do Brasil Interpretada e Legislação Constitucional. São Paulo: Atlas.

(2009). Direito Constitucional. 24. ed. São Paulo: Atlas. 
(2010). "Direito administrativo judiciário: atuação do Conselho Nacional de Justiça na interpretação dos impedimentos da magistratura”. In: MOREIRA, Eduardo Ribeiro; GONÇALVES JÚNIOR, Jerson Carneiro; BETTINI, Lucia Helena Polleti. (Orgs.). Hermenêutica constitucional: homenagem aos 22 anos do grupo de estudos Maria Garcia. São José-SC: Conceito Editorial.

NALINI, José Renato (2004). "Os três eixos da Reforma do Judiciário". Revista do Advogado. V. 24, n. 75, pp. 67-72, abril de 2004. São Paulo

NEVES, Marcelo (2007). A constitucionalização simbólica. 2. ed. São Paulo: Martins Fontes.

NIEMEYER, Sérgio (2012). “A competência do CNJ não é nem pode ser concorrente”. Artigo publicado em 16 de janeiro de 2012 no site Consultor Jurídico. Disponível online em: http:/www.conjur.com.br/2012-jan-16/competencia-cnj-nao-concorrentesubsidiaria-corregedorias. Acesso em 23/09/2012.

NOBRE, Marcelo (2012). CNJ protagoniza a construção da credibilidade da Justiça. Disponível online em: http://www.conjur.com.br/2012-jan-05/retrospectiva-2011cnj-protagoniza-construcao-credibilidade-justica. Acesso em 05/06/2012.

NOBRE, Milton Augusto de Brito (2012). Competência do CNJ é concorrente à dos tribunais. Disponível online em: http://www.conjur.com.br/2012-jan06/competencia-cnj-concorrente-tribunais-nao-censurada. Acesso em 05/06/2012.

O 'DONNELL, Guillermo (1998). Accountability horizontal e novas poliarquias. São Paulo: Lua Nova, n. 44. Disponível em $<\mathrm{http}: / /$ www.scielo.br/scielo.php?script=sci_arttext\&pid=S0102$64451998000200003 \& \operatorname{lng}=\mathrm{en} \& \mathrm{nrm}=\mathrm{iso}>$. Acesso em 29/11/2012.

PEDERSOLI, Christiane Vieira Soares (2009). “A atribuição Regulamentar do Conselho Nacional de Justiça: um estudo sobre a concretização normativa (in)direta da Constituição da República Brasileira em nível regulamentar”. Dissertação de Mestrado apresentada ao Programa de Pós-Graduação em Direito da Pontifícia Universidade Católica de Minas Gerais. 
PENALVA, Janaína; COSTA, Adriene Domingues (2010). “O novo regimento interno do Conselho Nacional de Justiça". In: Conteúdo Jurídico. Artigos. 28 de Setembro de 2010. Disponível em: http://www.conteudojuridico.com.br/?artigos\&ver=2.29135. Acesso em: 20/06/2011.

PONTES DE MIRANDA, Francisco Cavalcanti (1970). Comentários à Constituição de 1967, com a Emenda n. 1, de 1969. Tomo III (Arts. 32-117). 2. ed. São Paulo: Revista dos Tribunais.

ROBL FILHO, Ilton Norberto (2012). “Accountability e independência judiciais: o desenho institucional do Judiciário e do Conselho Nacional de Justiça no Estado Democrático de Direito Brasileiro". Tese de Doutorado apresentada à Universidade Federal do Paraná. Curitiba.

RODRIGUES, Leandro Nascimento (2008). "O Conselho Nacional de Justiça como instrumento de accountability horizontal: análise do período 2005-2007”. Dissertação de Mestrado apresentada à Universidade de Brasília. Brasília.

RULLI NETO, Antônio (2007). “Controle Externo do Poder Judiciário no Brasil”. Tese de Doutorado apresentada à Faculdade de Direito da Universidade de São Paulo. São Paulo.

SADEK, Maria Tereza (2001). "Controle externo do poder judiciário". In: (Org.). Reforma do judiciário. São Paulo: Fundação Konrad Adenauer. (2012). “A dessacralização do Judiciário". O Estado de São Paulo. Edição de 14 de Janeiro de 2012. Disponível online em: http://www.estadao.com.br/noticias/impresso,a-dessacralizacao--do-judiciario,822570,0.htm. Acesso em 21/06/2012.

SAMPAIO, José Adércio Leite (2007). O Conselho Nacional de Justiça e a Independência do Judiciário. Belo Horizonte: Del Rey.

SCHWARTZ, Hamilton Rafael Marins (2009). “O Poder Regulamentar do Conselho Nacional de Justiça". Dissertação de Mestrado apresentada às Faculdades Integradas do Brasil. Curitiba. 
SIFUENTES, Monica Jaqueline (2000). Conselho Superior da Magistratura - a experiência portuguesa. Brasília: Lex, vol. 265.

SILVA, José Afonso (2005). Curso de Direito Constitucional. 27 ed. São Paulo: Malheiros.

(2006). Comentário contextual à Constituição. 2. ed. São Paulo: Malheiros.

SLAIBI FILHO, Nagib (2005). Reforma da Justiça. Niterói: Impetus.

STRECK, Lenio Luiz; SARLET, Ingo Wolfgang; CLÉVE, Clémerson Merlin (2005). “Os limites constitucionais das Resoluções do Conselho Nacional de Justiça (CNJ) e Conselho Nacional do Ministério Público (CNMP)". Revista da ESMESC. v. 12, pp. 16-26. Florianópolis.

TAYLOR, Matthew; BURANELLI, Vinícius (2005). “Acabando em pizza: o processo de responsabilização pela corrupção no governo federal”. XXIX Encontro Anual da ANPOCS 25 a 29 de outubro de 2005. Disponível em: http://www.anpocs.org/portal/index.php?option=com_docman\&task=doc_view\&gid $=3786 \&$ Itemid $=318$. Acesso em 28/12/2012.

VELLOSO, Carlos Mário da Silva (1994). Controle externo do poder judiciário e controle de qualidade do judiciário e da magistratura: uma proposta. Brasília: Senado Federal, Subsecretaria de Edições Técnicas.

VIANNA, Luiz Werneck et al (1997). Corpo e alma da magistratura brasileira. Rio de Janeiro: Revan.

ZACLIS, Lionel (2012). “A competência disciplinar do CNJ”. Migalhas. Edição de 03 de fevereiro de 2012. http://www.migalhas.com.br/dePeso/16,MI149405,91041$\mathrm{A}+$ competencia+disciplinar+do+CNJ Acesso em: 21/06/2012.

ZAFFARONI, Eugenio Raúl (1995). Poder judiciário: crises, acertos e desacertos. Trad. de Juarez Tavares. São Paulo: Revista dos Tribunais. 


\section{BIBILIOGRAFIA CONSULTADA}

ALMEIDA JUNIOR, João Mendes de (1960). Direito Judiciário Brasileiro. 5. ed. Rio de Janeiro: Freitas Bastos.

ALMEIDA, Jorge Luiz de (2006). A Reforma do Poder Judiciário. Uma abordagem sobre a Emenda Constitucional n. 45/2004. Campinas: Millennium.

ARAÚJO, André Luís de Toledo (2009). "O Conselho Nacional de Justiça como uma das formas de minimização da morosidade processual". Dissertação de Mestrado apresentada à UNIVEM. Marília.

BARROSO, Luís Roberto (2005). "Constitucionalidade e Legitimidade da Criação do Conselho Nacional de Justiça”. In: RENAULT, Sérgio Rabello Tamm, BOTTINI, Pierpaolo (Coord.) Reforma do Judiciário. São Paulo: Saraiva, pp. 53-85.

BASTOS, Márcio Thomaz (2004). "Conselho Nacional de Justiça e o controle do poder judiciário". Revista do Tribunal de Contas da União, Brasília, v. 35, n. 99, jan./mar. 2004, pp. 7-10.

BODIGUEL, Jean-Luc (1991). Lês magistrats, un corps sans ame? Paris: Presses Universitaires de France.

CAMARGO, Maria Auxiliadora Castro (2004). "Reforma do judiciário, Tribunal Constitucional e Conselho Nacional de Justiça: controles externos ou internos". Revista de Informação Legislativa, v. 41, n. 164, out./dez. 2004, pp. 367-381.

CAPPELLETTI, Mauro; GARTH, Bryant (1988). Acesso à justiça. Trad. de Ellen Gracie Northfleet. Porto Alegre: Fabris.

CARDOZO, José Eduardo Martins (2005). "Direitos e deveres de magistrados e membros do Ministério Público". In: RENAULT, Sérgio Rabello Tamm, BOTTINI, Pierpaolo.(Coord.) Reforma do Judiciário. São Paulo: Saraiva, pp. 99-157. 
CERQUEIRA, Marcelo (1995). Controle do judiciário: doutrina e controvérsia, a constituição, controles e controle externo do poder judiciário. Rio de Janeiro: Revan.

COMPARATO, Fábio Konder (1998). “Juízes independentes ou funcionários subordinados?” In: Cidadania e Justiça, v. 2, n. 4, pp. 89-93, jan/jun. 1998.

CRETELla JUNIOR, José (1992). Comentários à Constituição Brasileira de 1988. Rio de Janeiro: Forense.

DINO, Flávio (2006). "O Conselho Nacional de Justiça: missões e primeiros passos". Advocacia Dinâmica: seleções jurídicas, abril de 2006, n. 4, pp. 8-13.

GANDRA DA SILVA MARTINS FILHO, Ives (2010). O CNJ e a racionalização judicial. Disponível em: <http://www.oglobo.com.br>. Acesso em: 20/06/2010.

GARAPON, Antoine (2001). O juiz e a democracia: o guardião das promessas. Rio de Janeiro: Revan.

GODOY, Cláudio Luiz Bueno de (2003). "Responsabilidade disciplinar dos juízes. Controle interno da magistratura". In: FREITAS, Vladimir Passos et al (Org.). Corregedorias do Poder Judiciário. São Paulo: RT.

GUSTAPANE, Antonello (1999). L'autonomia e l'independenza della Magistratura ordinária nel sistema constituzionale italiano. Dagli albori dello Statuto Albertino al crepusculo della Bicamerale. Milano: Giuffré.

LEWANDOWSKI, Enrique R (1999). A Reforma do Judiciário e o federalismo brasileiro. Revista do Advogado, n. 56, pp. 39-43.

(2010). Do descumprimento do princípio do juízo natural - CNJ não possui competência originária para instaurar processo administrativo disciplinar contra magistrado - Princípio da subsidiariedade. In: Âmbito Jurídico, Rio Grande, XIII, n. 80, set 2010. Disponível em: <http://www.ambitojuridico.com.br/site/?n link=revista_artigos_leitura\&artigo id=8282\&revista_cadern $\mathrm{o}=4>$. Acesso em 15/07/2012. 
MATTOS, Mauro Roberto Gomes de (2004). "Necessidade de justa causa para a instauração de processo administrativo disciplinar - impossibilidade do procedimento genérico para que no seu curso se apure se houve ou não falta funcional”. In: Âmbito Jurídico, Rio Grande, VII, n. 17, maio de 2004. Disponível em: $<$ http://www.ambitojuridico.com.br/site/index.php?n_link=revista_artigos_leitura \&artigo_id=3929>. Acesso em 14/07/2012.

MAINWARING, Scott (2003). Introduction: Democratic Accountability in Latin America. In. Democratic Accountability in Latin America. Oxford: Oxford University Press, 2003. Disponível online em: http://fds.oup.com/www.oup.co.uk/pdf/0-19-9256373.pdf. Acesso em 29/11/2012.

MARTINEZ, Ramses Henrique (2012). "Processo Judicial Eletrônico: uma abordagem metodológica para o processo de sua implementação". Tese de Doutorado apresentada à Faculdade de Economia, Administração e Contabilidade da Universidade de São Paulo. São Paulo.

MELLO FILHO, José Celso de (2004). “Algumas reflexões sobre a questão judiciária”. In: Revista do Advogado, v. 24, n. 75, pp. 43-53.

MELO FILHO, Hugo Cavalcanti (2003). “A reforma do poder judiciário brasileiro: motivações, quadro atual e perspectiva". Revista CEJ, n. 21, abr./jun. 2003, pp. 7986.

NALINI, José Renato (2005). “A democratização da administração dos tribunais". In: RENAULT, Sérgio Rabello Tamm, BOTTINI, Pierpaolo.(Coord.) Reforma do Judiciário. São Paulo: Saraiva, pp. 159-184.

(2009). "Ética da magistratura: Comentários ao Código de Ética da Magistratura Nacional'. São Paulo: Revista dos Tribunais.

NETTO, João Cláudio (2004). “Judiciário vai ao Senado contra controle externo: presidentes de tribunais pressionam o Congresso: ministros queixam-se da proposta de controle externo do poder judiciário". Jornal de Brasília, 24 março de 2004, Capa, p. 12. 
NORTHFLEET, Ellen Gracie (2003). "A análise dos fatores relevantes para o aprimoramento do sistema judiciário”. In: WALD, Arnoldo; MARTINS, Ives Gandra S.; PRADO, Ney (Coord.). O direito brasileiro e os desafios da economia globalizada. Rio de Janeiro: América Jurídica.

OLIVEIRA, Fabiana Ambrozio de (2010). Morosidade processual: o papel do Conselho Nacional de Justiça. Brasília. Disponível em: http://bdjur.stj.jus.br/dspace/handle/2011/31217. Acesso em: 23/06/2011

RENAULT, Sérgio Rabello Tamm, BOTTINI, Pierpaolo (2005). "Primeiro Passo". In: RENAULT, Sérgio Rabello Tamm, BOTTINI, Pierpaolo.(Coord.) Reforma do Judiciário. São Paulo: Saraiva, pp. 1-12.

RICHA, Morgana. CONSELHO NACIONAL DE JUSTIÇA (2011). Entrevista. Disponível em: http://www.cnj.jus.br/entrevista-com-os-conselheiros/15080morgana-richa-cnj-e-um-divisor-de-aguas-para-o-modelo-de-justica-brasileiro. Acesso em: 18/07/2011

ROCHA, Luiz Alberto G. S. (2009). "Novo perfil do Poder Judiciário brasileiro". In: Revista de direito constitucional e internacional. Ano 17, n. 67, abr./jun., 2009, Rio de Janeiro.

SANTOSUOSSO, Fernando (1958). Consiglio Superiore della Magistatura: principi e procedenti, legge institutive. Milano: Giuffré.

SCHEDLER. Andreas. (1999). "Conceptualizing Accountability”. In: The Self Restraining State: power and Accountability in new democracies. pp. 13-28. Boulder and London: Lynne Rienner Publishers, pp. 13-28. Disponível online em: http://works.bepress.com/andreas_schedler/22/. Acesso em 01/12/12.

UCHOA, Marcelo Ribeiro (2008). Controle do Poder Judiciário: da expectativa à concretização. O primeiro biênio do Conselho Nacional de Justiça. Florianópolis: Conceito Editorial. 


\section{ANEXO I - QUADRO ESQUEMÁTICO - RESUMO DO}

\section{JULGAMENTO DA ADI 4638-MC}

\begin{tabular}{|c|c|c|c|}
\hline $\begin{array}{c}\text { Resolução } \\
\text { n. } \\
\text { 135/2011 } \\
\text { do CNJ }\end{array}$ & $\begin{array}{l}\text { ARGUMENTOS } \\
\text { DA AMB }\end{array}$ & $\begin{array}{l}\text { VOTO DO MINISTRO } \\
\text { MARCO AURÉLIO }\end{array}$ & DECISÃO DO STF \\
\hline Art. $2^{\circ}$ & $\begin{array}{l}\text { Volta-se contra a } \\
\text { denominação de } \\
\text { "tribunal" ao Conselho } \\
\text { Nacional de Justiça e } \\
\text { ao Conselho de Justiça } \\
\text { Federal, uma vez que } \\
\text { a Carta da República } \\
\text { conferiu-lhes mera } \\
\text { atribuição } \\
\text { administrativa. }\end{array}$ & $\begin{array}{l}\text { Não procede o pedido } \\
\text { formulado, tendo em vista que o } \\
\text { artigo não define o Conselho } \\
\text { Nacional de Justiça e o Conselho } \\
\text { da Justiça Federal como } \\
\text { Tribunais, pois o que o vocábulo } \\
\text { "tribunal" revela somente que se } \\
\text { seguem são aplicáveis também a } \\
\text { tais Conselhos, pois são } \\
\text { submissos à Resolução. }\end{array}$ & $\begin{array}{l}\text { O STF, por maioria, } \\
\text { referendou } \\
\text { indeferimento } \\
\text { liminar. Consignou-se } \\
\text { que o CNJ integraria a } \\
\text { estrutura do Poder } \\
\text { Judiciário, porém não } \\
\text { seria órgão jurisdicional e } \\
\text { não interviria na atividade } \\
\text { judicante. }\end{array}$ \\
\hline $\begin{array}{l}\text { Art. } 3^{\circ} \\
\text { inciso } \mathbf{V}\end{array}$ & $\begin{array}{l}\text { Afirma que o preceito } \\
\text { impugnado excluiria o } \\
\text { direito ao recebimento } \\
\text { dos vencimentos } \\
\text { proporcionais em caso } \\
\text { de aposentadoria } \\
\text { compulsória. }\end{array}$ & $\begin{array}{l}\text { Não procede } \mathbf{0} \text { pedido } \\
\text { formulado, pois a Resolução } \\
\text { impugnada não dispõe em sentido } \\
\text { contrário do art. 103-B, } \S 4^{\circ} \text {, } \\
\text { inciso III, da CF. Ademais, não } \\
\text { permite a interpretação de que a } \\
\text { sanção de aposentadoria } \\
\text { compulsória seria aplicável sem o } \\
\text { subsidio ou os proventos } \\
\text { correspondentes. Caso contrário, } \\
\text { tratar-se-ia de perda de cargo. }\end{array}$ & $\begin{array}{l}\text { Referendou-se } \\
\text { indeferimento da } \\
\text { liminar. Registrou-se que } \\
\text { a declaração de } \\
\text { inconstitucionalidade de } \\
\text { tal artigo pressuporia } \\
\text { conflito manifesto com } \\
\text { norma constitucional, } \\
\text { inexistente na espécie e, } \\
\text { assim, deveria ser } \\
\text { mantida sua eficácia. }\end{array}$ \\
\hline$\underset{1^{\circ}}{\operatorname{Art.} 3^{\circ}, \S}$ & 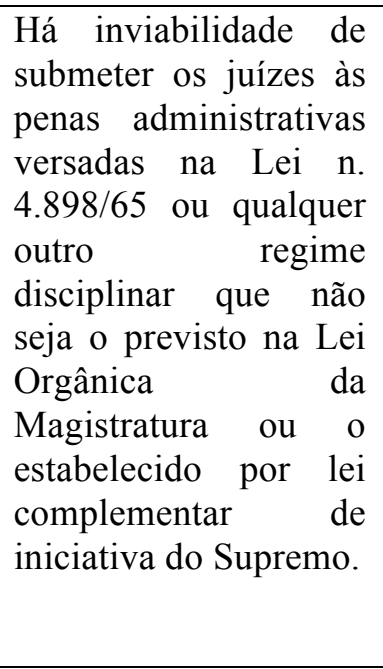 & $\begin{array}{l}\text { Procede o pedido formulado. Os } \\
\text { juízes brasileiros respondem } \\
\text { administrativa e penalmente pela } \\
\text { prática de abuso de autoridade. } \\
\text { Todavia, a possibilidade de os } \\
\text { magistrados responderem } \\
\text { disciplinarmente por ato } \\
\text { caracterizador de abuso de } \\
\text { autoridade não implica em } \\
\text { sujeição às penas administrativas } \\
\text { versadas na Lei n. 4.898/65, uma } \\
\text { vez que as sanções que lhes } \\
\text { podem ser aplicadas estão } \\
\text { versadas de modo taxativo na Lei } \\
\text { Orgânica da Magistratura. }\end{array}$ & $\begin{array}{l}\text { Referendou-se, por } \\
\text { maioria, o deferimento } \\
\text { da liminar. Mesmo que } \\
\text { os } \\
\text { respondam } \\
\text { disciplinarmente por ato } \\
\text { caracterizador de abuso } \\
\text { de autoridade, a eles não } \\
\text { se aplicariam as penas } \\
\text { administrativas versadas } \\
\text { na Lei n. } 4.898 / 65 \text {, } \\
\text { porquanto submetidos à } \\
\text { disciplina especial } \\
\text { derrogatória, qual seja, a } \\
\text { LOMAN. }\end{array}$ \\
\hline $\begin{array}{l}\text { Art. } 4^{\circ} \mathrm{e} \\
\quad 20\end{array}$ & $\begin{array}{l}\text { Afirma que o art. } 4^{\circ} \\
\text { ter implicado a } \\
\text { supressão da exigência } \\
\text { de sigilo na imposição } \\
\text { das sanções de } \\
\text { advertência e censura, } \\
\text { consoante preconizado } \\
\text { na Lei Orgânica da } \\
\text { Magistratura. Somente } \\
\text { outro Estatuto da }\end{array}$ & $\begin{array}{l}\text { Não procede o pedido } \\
\text { formulado. É necessário que as } \\
\text { decisões em processos } \\
\text { disciplinares que envolvam } \\
\text { magistrados sejam tomadas à luz } \\
\text { da democracia. Não é dado a } \\
\text { juízes e órgãos sancionadores o } \\
\text { direito de eximir-se da } \\
\text { fiscalização da sociedade. O } \\
\text { sigilo imposto com o objetivo de }\end{array}$ & $\begin{array}{l}\text { No tocante ao art. } 4^{\mathbf{0}} \text {, } \\
\text { referendou-se, por } \\
\text { maioria, } \\
\text { indeferimento } \\
\text { liminar. Afastou-se da } \\
\text { assertiva de que a } \\
\text { supressão da exigência de } \\
\text { sigilo na imposição das } \\
\text { sanções de advertência e } \\
\text { censura deveriam ser }\end{array}$ \\
\hline
\end{tabular}




\begin{tabular}{|c|c|c|c|}
\hline & $\begin{array}{l}\text { Magistratura Orgânica } \\
\text { poderia inovar sobre o } \\
\text { tema, conforme o art. } \\
\text { 93, IX, da Carta da } \\
\text { República. } \\
\text { Já o art. } 20 \text { aponta o } \\
\text { interesse público na } \\
\text { decretação de sigilo } \\
\text { nos processos } \\
\text { disciplinares } \\
\text { instaurados contra } \\
\text { magistrados, tendo em } \\
\text { vista a manutenção da } \\
\text { credibilidade do Poder } \\
\text { Judiciário. Ademais, } \\
\text { anota que a atual } \\
\text { redação do art. 93, IX, } \\
\text { da CF não obsta a } \\
\text { realização de sessão } \\
\text { fechada. }\end{array}$ & $\begin{array}{l}\text { proteger a honra dos magistrados } \\
\text { contribui para um ambiente de } \\
\text { suspeição e não para a } \\
\text { credibilidade da magistratura. } \\
\text { Os dispositivos (art. 93, IX e X, } \\
\text { da CF) estão em plena } \\
\text { consonância com os ditames } \\
\text { democrático e republicano. Além } \\
\text { disso, o art. 37, da CF, dispõe que } \\
\text { a Administração Pública está } \\
\text { submetida aos princípios da } \\
\text { legalidade, da impessoalidade, da } \\
\text { moralidade, da publicidade e da } \\
\text { eficiência. } \\
\text { A EC n. 45/2004, não impede a } \\
\text { realização de sessões reservadas } \\
\text { para garantir o direito à } \\
\text { intimidade, contudo, exige } \\
\text { fundamentação específica para a } \\
\text { decretação de sigilo no processo } \\
\text { disciplinar, pois a transparência é } \\
\text { a tônica da atividade pública. } \\
\text { Dessa forma, a Resolução do } \\
\text { CNJ, ao prever a publicidade das } \\
\text { sanções disciplinares e da sessão } \\
\text { de julgamento, não extrapola os } \\
\text { limites normativos nem ofende } \\
\text { garantia da magistratura. }\end{array}$ & $\begin{array}{lr}\text { aplicadas nos } & \text { moldes } \\
\text { preconizados } & \text { na } \\
\text { LOMAN. } & \\
\text { Quanto ao art. } & \mathbf{2 0 ,} \\
\text { referendou-se } & \text { o } \\
\text { indeferimento } & \text { da } \\
\text { liminar. O respeito ao } \\
\text { Poder Judiciário não } \\
\text { poderia ser obtido por } \\
\text { meio da blindagem } \\
\text { destinada a proteger do } \\
\text { escrutínio público os } \\
\text { juízes e o órgão } \\
\text { sancionador, o que seria } \\
\text { incompatível com a a } \\
\text { liberdade de informação e } \\
\text { com a ideia de } \\
\text { democracia. }\end{array}$ \\
\hline $\begin{array}{c}\text { Art. } 8^{\circ} \text { e } \S \\
2^{\circ} \text { e } \S 3^{\circ} \\
\text { do art. } 9^{\circ}\end{array}$ & $\begin{array}{lrr}\text { Ressalta a distinção } & \text { desarrazoada } & \text { entre os } \\
\text { juízes, uma vez que os } \\
\text { de } 1^{\circ} \text { grau } & \text { serão } \\
\text { processados } & \text { pelo } \\
\text { Corregedor } & \text { e } & \text { os } \\
\text { demais } & \text { pela } \\
\text { Presidência. Argui a } \\
\text { invasão } & \text { da } \\
\text { competência } & \\
\text { regimental } & \text { dos } \\
\text { tribunais e aduz não } \\
\text { existir justificativa } \\
\text { para atribuir à à } \\
\text { Presidência função } \\
\text { típica da Corregedoria. }\end{array}$ & $\begin{array}{l}\text { Decisões diversas. O poder } \\
\text { fiscalizatório, administrativo e } \\
\text { disciplinar conferido pela CF ao } \\
\text { CNJ não o autoriza a invadir o } \\
\text { campo de atuação dos tribunais } \\
\text { concernente à definição das } \\
\text { atribuições dos respectivos órgãos } \\
\text { jurisdicionais a administrativos. } \underline{O} \\
\text { disposto no art. } 8^{\circ} \text { e nos } \S \S 2^{\circ} \text { e } 3^{\circ} \\
\text { do art. } 9^{\circ} \text { interfere de forma direta } \\
\text { na autonomia político- } \\
\text { administrativa dos tribunais para } \\
\text { dispor sobre a competência dos } \\
\text { próprios órgãos, em afronta aos } \\
\text { arts. 96, I, a, e 99, da CF. Não } \\
\text { cabe ao CNJ definir quem será a } \\
\text { autoridade responsável pelo envio } \\
\text { dos dados, sob pena de } \\
\text { contrariedade aos artigos } \\
\text { supracitados. } \\
\text { Em relação ao caput do art. } 9^{\circ}, \\
\text { não procede à alegação da } \\
\text { requerente, já que a representação } \\
\text { contra servidores insere-se no } \\
\text { direito de petição consagrado no } \\
\text { art. } 5^{\circ} \text {, XXXIV, alínea "a". }\end{array}$ & $\begin{array}{l}\text { O Plenário atribuiu } \\
\text { interpretação conforme } \\
\text { a Constituição. Ressalta- } \\
\text { se, ainda, que onde conste } \\
\text { "Presidente" } \\
\text { "Corregedor", seja lido } \\
\text { "órgão competente do } \\
\text { tribunal". }\end{array}$ \\
\hline
\end{tabular}




\begin{tabular}{|c|c|c|c|}
\hline Art. 10 & $\begin{array}{l}\text { O modo que foi } \\
\text { redigido o artigo se } \\
\text { abre caminho para a } \\
\text { interpretação no } \\
\text { sentido da pertinência } \\
\text { de interpor recurso ao } \\
\text { CNJ contra a decisão } \\
\text { proferida } \\
\text { tribunais, pois o CNJ } \\
\text { passou a } \\
\text { autodeterminar } \\
\text { "tribunal". }\end{array}$ & $\begin{array}{l}\text { Procede o pedido formulado, } \\
\text { pois o fato de a representação } \\
\text { formalizada na corregedoria do } \\
\text { tribunal ter sido arquivada não } \\
\text { consubstancia óbice à atividade } \\
\text { subsidiária. } \\
\text { O artigo } 103-\mathrm{B} \text {, incisos III e V do } \\
\S 4^{\circ} \text {, da CF, não autorizam o } \\
\text { Conselho a instituir, em caráter } \\
\text { geral e abstrato, recurso no } \\
\text { procedimento disciplinar em } \\
\text { trâmite nos tribunais, sob pena de } \\
\text { ofensa à reserva de lei } \\
\text { complementar. }\end{array}$ & $\begin{array}{l}\text { O Supremo, por } \\
\text { maioria, conferiu } \\
\text { interpretação conforme } \\
\text { a Constituição ao artigo } \\
\text { em tela para, excluindo a } \\
\text { expressão "por parte do } \\
\text { autor da representação", } \\
\text { entender-se que o sentido } \\
\text { da norma seria o da } \\
\text { possibilidade de recurso } \\
\text { pelo interessado, seja ele } \\
\text { magistrado contra o qual } \\
\text { se instaura o } \\
\text { procedimento, seja ele o } \\
\text { autor da representação } \\
\text { arquivada. }\end{array}$ \\
\hline $\begin{array}{c}\text { Art. } 12 \\
\text { caput e } \\
\text { parágrafo } \\
\text { único }\end{array}$ & $\begin{array}{l}\text { No caput do artigo há } \\
\text { estabelecido } \\
\text { competência } \\
\text { concorrente entre o } \\
\text { CNJ e os tribunais, } \\
\text { contrariando o art. } \\
\text { 103-B, III, da CF de } \\
\text { 1988, a prever a } \\
\text { competência } \\
\text { subsidiária do } \\
\text { Conselho. } \\
\text { O parágrafo único } \\
\text { revela outra inversão } \\
\text { de competência, tendo } \\
\text { em vista que os } \\
\text { tribunais terão que } \\
\text { olhar primeiro a } \\
\text { resolução do CNJ e, } \\
\text { apenas os } \\
\text { subsidiariamente, os } \\
\text { respectivos regimentos } \\
\text { internos. }\end{array}$ & $\begin{array}{l}\text { Em relação ao caput, confere } \\
\text { interpretação conforme a } \\
\text { Constituição, para assentar, em } \\
\text { âmbito disciplinar, a competência } \\
\text { subsidiária do Conselho Nacional } \\
\text { de Justiça. } \\
\text { Quanto ao parágrafo único, } \\
\text { procede o pedido formulado, } \\
\text { pois se verifica a invasão da } \\
\text { autonomia administrativa dos } \\
\text { tribunais para regular o } \\
\text { procedimento disciplinar, nos } \\
\text { termos do artigo 96, I, alínea "a", } \\
\text { da CF e na Lei Orgânica da } \\
\text { Magistratura. }\end{array}$ & $\begin{array}{l}\text { O Plenário, por maioria, } \\
\text { negou referendo à } \\
\text { liminar e manteve a } \\
\text { competência originária e } \\
\text { concorrente do Tribunal } \\
\text { para instaurar } \\
\text { procedimentos } \\
\text { administrativos } \\
\text { disciplinares aplicáveis a } \\
\text { magistrados. }\end{array}$ \\
\hline $\begin{array}{c}\text { Art. 14, } \\
\text { caput, } \S \\
3^{\circ}, \S 7^{\circ}, \S \\
8^{\circ} \text { e } \S 9^{\circ}, \\
\text { art. } 17, \\
\text { caput, IV } \\
\text { e V, e do } \\
\text { art. } 20, \S \\
3^{\circ} .\end{array}$ & 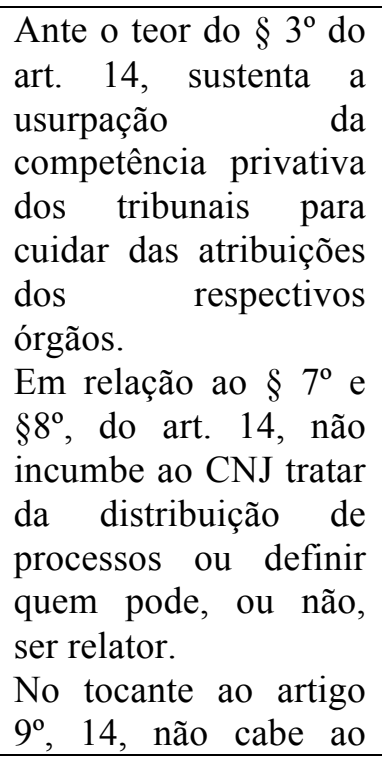 & $\begin{array}{l}\text { Procede o pedido formulado. } \\
\text { Ao CNJ não é permitido, no } \\
\text { processo disciplinar dos tribunais, } \\
\text { criar novos procedimentos e } \\
\text { definir quem será o relator ou se } \\
\text { existirá, ou não, revisor. Ainda, } \\
\text { não lhe cabe determinar prazo } \\
\text { para a conclusão. } \\
\text { Ademais, falece ao CNJ definir } \\
\text { quem participará do julgamento } \\
\text { no âmbito dos tribunais. }\end{array}$ & $\begin{array}{l}\text { Negou-se, por maioria, o } \\
\text { referendo à cautelar } \\
\text { desses artigos. }\end{array}$ \\
\hline
\end{tabular}




\begin{tabular}{|c|c|c|c|}
\hline & $\begin{array}{l}\text { CNJ fixar para os } \\
\text { tribunais os prazos de } \\
\text { duração do processo } \\
\text { administrativo } \\
\text { disciplinar. } \\
\text { O art. } 17 \text { institui nova } \\
\text { etapa de defesa não } \\
\text { prevista na legislação } \\
\text { complementar. } \\
\text { Por fim, afirma que o } \\
\text { artigo } 20 \text { sustenta } \\
\text { caber ao CNJ fixar os } \\
\text { parâmetros do } \\
\text { procedimento de } \\
\text { votação em processo } \\
\text { disciplinar que tramita } \\
\text { perante o tribunal. }\end{array}$ & & \\
\hline $\begin{array}{l}\S 1^{\circ} \text { do } \\
\text { art. } 15\end{array}$ & $\begin{array}{l}\text { Há violação } \\
\text { garantias das } \\
\text { vitaliciedade e da } \\
\text { inamovibilidade e à } \\
\text { invasão de matéria } \\
\text { reservada a lei } \\
\text { complementar, já que } \\
\text { o parágrafo único } \\
\text { autoriza o afastamento } \\
\text { do juiz antes da } \\
\text { instauração } \\
\text { processo disciplinar. }\end{array}$ & $\begin{array}{l}\text { Procede o pedido formulado, } \\
\text { pois está em descompasso com a } \\
\mathrm{CF} \text { a introdução mediante ato } \\
\text { normativo do CNJ, de nova } \\
\text { hipótese cautelar de afastamento } \\
\text { de magistrado do cargo. }\end{array}$ & $\begin{array}{l}\text { O Colegiado } \\
\text { referendou, por votação } \\
\text { majoritária, a liminar } \\
\text { concedida, uma vez que } \\
\text { se trata de nova hipótese } \\
\text { cautelar de afastamento } \\
\text { de magistrado do cargo. } \\
\text { A eventual restrição às } \\
\text { garantias } \\
\text { inamovibilidade e da } \\
\text { vitaliciedade exigiria a } \\
\text { edição de lei em sentido } \\
\text { formal e material, sob } \\
\text { pena de ofensa aos } \\
\text { princípios da legalidade e } \\
\text { do devido processo. }\end{array}$ \\
\hline $\begin{array}{c}\text { Art. 21, } \\
\text { Parágrafo } \\
\text { único }\end{array}$ & $\begin{array}{l}\text { Alega } \\
\text { inconstitucionalidade } \\
\text { ante a } \\
\text { inadmissibilidade de } \\
\text { punição de magistrado } \\
\text { sem o voto da maioria } \\
\text { absoluta dos membros } \\
\text { do tribunal. }\end{array}$ & $\begin{array}{l}\text { Subsiste o pedido de suspensão } \\
\text { do preceito, uma vez que este } \\
\text { conflita com a parte final do } \\
\text { artigo 93, X, da CF, em que } \\
\text { preconiza o voto da maioria dos } \\
\text { membros do tribunal para a } \\
\text { tomada de decisões disciplinares. }\end{array}$ & $\begin{array}{l}\text { O Tribunal, por } \\
\text { maioria, deu } \\
\text { interpretação conforme } \\
\text { a Constituição para } \\
\text { entender que deve haver } \\
\text { votação específica de } \\
\text { cada uma das penas } \\
\text { disciplinares aplicáveis a } \\
\text { magistrados até que se } \\
\text { alcance a maioria } \\
\text { absoluta dos votos, } \\
\text { conforme preconizado no } \\
\text { art. 93. VIII, da CF. Tal } \\
\text { solução evitaria que o } \\
\text { juízo condenatório fosse } \\
\text { convolado em absolvição } \\
\text { ante a falta de consenso } \\
\text { sobre qual a penalidade } \\
\text { cabível. }\end{array}$ \\
\hline
\end{tabular}

